\title{
De organisatie van een virus : over de wereldgezondheidsorganisatie, wetenschap en transnationale gezondheidspolitiek
}

Citation for published version (APA):

de Bont, A. (2000). De organisatie van een virus : over de wereldgezondheidsorganisatie, wetenschap en transnationale gezondheidspolitiek. [, Maastricht University]. Universiteit Maastricht. https://doi.org/10.26481/dis.20000915ab

Document status and date:

Published: 01/01/2000

DOI:

10.26481/dis.20000915ab

Document Version:

Publisher's PDF, also known as Version of record

Please check the document version of this publication:

- A submitted manuscript is the version of the article upon submission and before peer-review. There can be important differences between the submitted version and the official published version of record.

People interested in the research are advised to contact the author for the final version of the publication, or visit the DOI to the publisher's website.

- The final author version and the galley proof are versions of the publication after peer review.

- The final published version features the final layout of the paper including the volume, issue and page numbers.

Link to publication

\footnotetext{
General rights rights.

- You may freely distribute the URL identifying the publication in the public portal. please follow below link for the End User Agreement:

www.umlib.nl/taverne-license

Take down policy

If you believe that this document breaches copyright please contact us at:

repository@maastrichtuniversity.nl

providing details and we will investigate your claim.
}

Copyright and moral rights for the publications made accessible in the public portal are retained by the authors and/or other copyright owners and it is a condition of accessing publications that users recognise and abide by the legal requirements associated with these

- Users may download and print one copy of any publication from the public portal for the purpose of private study or research.

- You may not further distribute the material or use it for any profit-making activity or commercial gain

If the publication is distributed under the terms of Article $25 \mathrm{fa}$ of the Dutch Copyright Act, indicated by the "Taverne" license above, 


\section{De organisatie van een virus}

\section{Over de wereldgezondheidsorganisatie, wetenschap en transnationale gezondheidspolitiek}

\section{PROEFSCHRIFT}

Ter verkrijging van de graad van doctor aan de Universiteit Maastricht, op gezag van de Rector Magnificus, Prof. dr. A.C. Nieuwenhuijzen Kruseman volgens het besluit van het College van Decanen, op vrijdag 15 september 2000 om 12.00 uur. 
Deze uitgave is mede mogelijk gemaakt dankzij financiële bijdragen van de Onderzoeksschool Wetenschap, Technologie en Moderne cultuur en de J. E. Jurriaanse stichting. 
Promotor:

Prof. dr. L. Boon

Co-promotor:

Dr. K. Horstman

Beoordelingscommissie:

Prof. dr. R.Vos (voorzitter)

Prof. dr. ir.W. Bijker

Dr. E. de Leeuw

Prof. dr. A. Mol (Universiteit Twente)

Prof. dr. N. Oudshoorn (Universiteit Twente) 
voor miin vader 


\section{inhoudsopgave}

Voorwoord

hoofdstuk $\|$ : Faciliteren, standaardiseren en registreren

De WHO als een technische en a-politieke organisatie

.1 Introductie

.2 Het beeld van de WHO

.3 Internationalle organisaties in het globaliseringsproces 21

.4 De opbouw van wetenschappelijke netwerken 26

.5 De casus $\quad 32$

.6 De opzet van de studie $\quad 37$

hoofdstuk 2: Bij gebrelk aan consensus

Over verschillen en eemheid in het WHO-netwerk 41

.1 Introductie 41

.2 Een contraverse over de effectiviteit wan HIV-vaccins 43

.3 Het WHO-netwerk te midden van de controverse 48

.4 De opbouw van het netwerk 52

.5 Slot 62

hoofdstuk 3: Registratiewerk

Hoe HIV de vorm krijgt van een RNA streng 65

.1 Introductie 65

.2 Van een ver land 66

.3 Opslag in het depot $\quad 72$

.4. Langs de secundaire laboratoria 76

.5 De eindbestemming: de database 83

$\begin{array}{ll}.6 \text { Slot } & 87\end{array}$

hoofdstuk 4: Transnationale verhoudingen

De kloof tussen Noord en Zuid in het WHO-netwerk 91

.1. Untroductie 9 |

.2 Van internationale gelijkheid naar een transnationale taakverdeling 93

.3 Een carrière in onderzoek voor patiënten 98

$\begin{array}{ll}.45 \text { Slot } & 104\end{array}$

hoofdstuk 5: Een transnationale en politieke kennisorganisatie

De WHO als netwerkbouwer $\quad 107$

.1 Introductie 107

2. De inspanmingen wan de WHO om te registreren 108

$\begin{array}{ll}3 \text { De effecten van registreren } & 109\end{array}$

.4 Hoe technisch is de aanpak van de WHO? 112

.5 Een ander beeld van de WHO 115

.6 De toekomst van de WHO 119

Noten

$\begin{array}{ll}\text { Literatuur } & 137\end{array}$

$\begin{array}{ll}\text { Bronnen } & 147\end{array}$

Summary 153 


\section{Voorwoord}

Velen hebben milj gesteund bij het voltooien van dit proefschrift.

Als eerste wil ik Louis Boon noemen. Het was zijn idee om een onderzoek te doen naar de ontwikkeling van internationale registratiesystemen en de problemen die daaraan verbonden zijn. Hij heeft me daarmee de kans gegeven om onderzoek te doen dat direct aansloot bij mijn interesse, de relatie tussen wetenschap en beleid. Hij was er niet altijd, maar voor de laatste loodjes, die inderdaad het zwaarst wegen, was hij er des te meer. Van Klasien Horstman heb ik het vak geleerd. zij heeft het meeste werk verzet door de teksten - hoe prematuur ook - telkens opnieuw te lezen en te corrigeren. I ben haar dankbaar voor alles wat ik van haar geleerd heb.

Het onderzoek dat ik heb gedaan bestaat vooral uit schrijven en herschrijven. Daarvoor zijn de suggesties en kritische opmerkingen van anderen op mijn teksten onmisbaar geweest. De meest bijzondere plek om een tekst te bespreken, is voor mij de aio-soep geweest. Elk maand bespraken we, na een kop soep, teksten van elkaar. De kritiek die we elkaar gaven was soms scherp, maar nooit hard omdat we van elkaar wisten hoe moeilijk het kan zijn eigen ideeën te ontwikkelen en te verwoorden. De kritiek die we op een tekst van de ander gaven. had meestal ook betrekking op ons zelf. Saskia, Ruud, Marik-Josee, Agnes, Michiel, Marc, Marleen, Irma, Marianne, Jessica, Nel en Roland, ik hoop dat we ook in de toekomst teksten van elkaar blijven lezen en becommentariëren. Ruth Benschop heeft de samenvatting voor mij in het Engels vertaald. Rein Vos, Evelyne de Leeuw, Harry Smit, Agnes Meershoek, Annemarie Mol, Roland Bal, Pë Mullenders hebben waardevol commentaar gegeven op het manuscript. Annemarie Mol wil ik graag speciaal bedanken voor de bijzondere gesprekken over dit onderzoek en het doen van onderzoek in het algemeen.

Na afloop van mijn aio-periode ben ik gaan werken bij het College van Toezicht Sociale Verzekeringen (Ctsv). Dankzij mijn werk bij het Ctsv heb ik meer afstand kurnen nemen van dit onderzoek. Zonder die afstand was mijn proefschrift voor 
een beperkter publiek toegankelijk geweest. Ik wil Reinoud Doeschot bedanken voor de ruimte die hij me heeft gegeven om naast mijn werk mijn proefschrift af te ronden.

Een aantal mensen heeft tijdens het onderzoek heel dicht bij mij gestaan. Met Saskia van der Lyke heb ik eindeloos gepraat over alles wat met promoveren te maken heeft. Ik heb mooie herinneringen aan de dagen dat we samen in Drenthe of in Maastricht aan ons proefschrift schreven. Ruud Hendriks is mijn studiemaatje vanaf de eerste keer dat we kennismaakten met de actor-netwerk-theorie van Latour. Mijn ouders hebben mij altijd gestimuleerd om verder te gaan. Hun voor mij onverwachte en daardoor zo bijzondere steun om met het onderzoek te stoppen, heeft me de rust gegeven om mijn proefschrift af te maken. Als laatste wil ik mijn vriend Joost Demmers bedanken. Ik heb Joost leren kennen op de avond voordat mijn Aio-contract begon. Op de dag dat ik mijn proefschrift verdedig kennen we elkaar precies acht jaar. Zonder jou had ik al die jaren nog harder gewerkt en had het nog langer geduurd voordat dit proefschrift af was. 


\title{
Faciliteren, standaardiseren en registreren
}

\section{De WHO als een technische en a-politieke organisatie}

\begin{abstract}
"In épn van de verhalen van de Baccaccio komt een jood voor die katholiek wil worden. Hij vraagt de priesters wat hij moet doen. "Naar Rome gaan" zeggen ze hem. Hij gaat en komt terug als christen. "Mooi zo" zeggen ze, "je bent zeker over de streep getrokken door de godsurucht van onze mensen in Rome?" "Nee", antwoordt hij.

Toen hij in Rome kwam, zag hij de Kerk in al haar losbandigheid en carruptie en wereldsheid. Priesters die in zonde leefden, nonnen met kinderen, de Heilige Vader zelf een verdorvene. En toen dacht hij: een kerk die al deze zonden begaat on het toch al meer dan duizend jaar withoudt, zo "n kerk moet iets hebben dat woor haar pletin".
\end{abstract}

\section{.1 Introductie}

In 1998 viert de Wereldgezondheidsorganisatie (WHO) haar vijftigste verjaardag. De WHO is één wan de bekendste internationale organisaties en heeft tot doel de gezondheid van mensen over de hele wereld op een zo hoog mogelijk niveau te brengen. Die doelstelling krijgt onder andere gestalte in de bekende verklaring Health for All by the year 2000.2 De WHO heeft bekendheid door dergelijke brede, lovenswaardige formuleringen van doelstellingen. laarlijks publiceert zij cijfers over de belangrijkste doodsoorzaken en ziekten in de wereld. Daarnaast voert de WHO concrete programma's uit, waarvan het meest succesvolle en groot. ste het wereldwijde pokkenvaccinatieprogramma is geweest. Dit programma heeft zelfs geleid tot de volledige uitbanning van de pokkem in 1978 . 
Rond het wiftigiarig bestaan van de WHO verschinnen tal van beschouwingen over de organisatie. De teneur van deze artikelen is echter weinig feestelijk: titels als "Crisis in de WHO'" of 'Speelt de WHO nog een rol in Europa?' zijn een indicatie voor de boodschap wan dergelijke beschouwingen. ${ }^{3}$ Volgens critici als Fiona Godlee en John Peabody wordt er te veel tijd en energie gestoken in commissies, vergaderingen en rapporten en te weinig in de uitvoering van het beleid. Wat hebben al die commissies, vergaderingen en rapporten opgeleverd? Naast vragen over de doelmatigheid van het beleid van de WHO, rijzen ook kwesties met betrekking tot de inhoud ervan. Dit is "zo vinden de critici, te eenzijdig gericht op de ontwikkeling wan medische kennis en de verbetering van gezondheidsvoorzieningen. De WHO zou veel meer kunnen bereiken wanneer zij in haar gezondheidsbeleid ook aandacht had voor sociaal-economische problemen als armoede, levensstijl of milieu. Dergelijke vraagstukken hebben echter meteen een politieke betekenis. Als internationale non-gouvernementele organisatie neigt de WHO er volgens critici naar om gevoelige onderwerpen die de verhoudingen tussen lidstaten kunnen werstoren, te mijden. De WHO doet daar bij voorkeur zelf geen uitspraken over. Zij verschuilt zich achter wetenschappelijk onderzoek en technische voorzieningen. Zo mist zij één van haar allerbelangrijkste functies; de wereld heeft juist een onafhankelijk forum nodig waar politiek gevoelige zaken kunnen worden besproken. Met meer durf zou de WHO za"n forum kunnen zijn.

Van de kant van de WHO wordt daar tegen ingebracht dat een strikt wetenschappelijke of technische aampak van gezondheidsproblemen een voorwaarde is om in thet internationale politieke krachtenveld overeind te blijven. Over heikele kwesties rond gezondheid kan volgens de WHO alleen door de inzet van wetenschappers en andere deskundigen tot consensus worden gekomen. 5 Sterker, de WHO heeft haar hele beleid in belangrijke mate gebouwd op de professionele consensus van deskundigen. Zo brengt zij over haar stafleden naar voren:

"Their ability to willstand diverse pressures is strengthened by the wnusually high degree of consensus among members of the Secretariat on organizational and professional valwes, a consensus largely altributable to their similar educational and career backgrounds in the field of medicine and public health: 6

De WHO gelooft wel dat zij indirect een bijdrage levert aan de oplossing van politieke vraagstukken. Investeringen in betere gezondheidsvoorzieningen over de hele wereld zijn volgens haar een maniler om de politieke stabiliteit te vergroten. ${ }^{7}$ In een wereld waar de verschillen in gezondheid kleiner zijn en er geen epidemieěn dreigen, zullen, zo veronderstelt de WHO, ook minder spanningen en conflicten tussen staten ontstaan. Voor de WHO is een technische aanpak van gezondheidsproblemen eigenlijk een alternatief voor de woelingen van de internationale politiek. Juist hier ziet de $W H O$ haar rol op het wereldtoneel en daarom wil zij ook in de toekomst vasthouden aan haar technisch georiënteerd beleid. Dat bliikt onder meer uit recente reorganisatieplannen.8 
Registratie van gezondheldsgegevens, standaardisatie van de aanpak van gezondheidsproblemen en ondersteuning bij de opbouw wan (intemationale) gezondheidsvoorzieningen worden voor de volgende eeuw als hoofdtaken van de WHO gedefinieerd.

Het is duidelijk dat twee gezichtspunten hier diametraal tegenover elkaar staan. Volgens critici pakt de WHO politiek gevoelige problemen niet aan, ondat de organisatie te eenzijdig gericht is op de verbetering van technische faciliteiten en de ontwikkeling van wetenschappelijke kennis. Volgens de WHO is het juist dankzij de inzet van medische deskundigheid dat gezondheidsprobiemen op een efficiëntere mamier kunnen worden aangepakt, omdat politiek geharrewar wordt vermeden.

Waar de critici de WHO tot een organisatie willen maken die een veel meer politieke rol speelt in het internationale gezondheidsbeleid, meent de WHO zelf dat zij daarin alleen dan een rol van betekenis kan spelen, wanneer zij zich beperkt tot een technisch wetenschappelijke aanpak. In dit debat komt zo de klassieke tegenstelling tussen wetenschap en politiek naar voren. Zowel de WHO als haal critici gaan er daarbij vanuit dat de aanpak van de WHO inderdaad puur technisch is. Hun opvattingen verschillen alleen in de evaluatie van die technische aanpak. Klopt echter die veronderstelling van beide partijen? Dat is de vraag. In deze studie wordt de technische invulling van de rol van de WHO kritisch onderzocht. Hoe technisch zijn de programma's van de WHO? Hoe zijn technische zaken mogelijk verweven met meer politieke vraagstukken?

Om een dergelijke vraag te onderzoeken zal in deze studie worden gekeken naar de ontwikkeling van een registratie van de WHO. Er zijn meerdere redenen om de aandacht juist op een registratie te richten. Registreren is een activiteit die de WHO zelf ziet als één van haar hoofdtaken voor de volgende eeuw. ${ }^{10}$ De WHO voert tal van registraties, waarvan de bekendste de internationale classificatie van doodsoorzaken is. Daarnaast beheert de WHO nog vele andere registraties zoals die van specifieke gezondheidsproblemen en ziekten "maar ook van gezondheidswoorzieningen in een land of de uitgaven woor gezondheidszorg. Registreren is zo niet alleen een belangrijke doelstelling van de WHO, maar maakt ook een belangrijk deel van haar feitelijke activiteiten uit. Ten slotte is een registratie op het eerste gezicht bij uitstek een puur technische aangelegenheid. Registreren kan, zo is mijn stelling, worden gezien als soort pars pro toto van de WHO-opvatting over de verhouding tussen wetenschap en politiek. De kern van het registreren van gezondheidsgegevens is een strikt onderscheid tussen wetenschappelijk onderzoek enerzijds en politieke besluitvorming andepzijds. Eerst worden de gegevens verzameld en daarna wordt een beslissing genomen over het te voeren beleid. Geregistreerde gegevens staan als onbetwijfelbare feiten. Wat komt meer overeen met onze alledaagse opvattingen over feiten dan de opsomming van karakteristieken in een registratie? Wat lijkt er minder doar theorieën of politieke voorkeuren gekleurd dan een simpele classificatie van feiten?

De bestudering van een registratie vormt daarmee een goede ingang om opvattilingen en praktijken met betrekking tot technische en politieke aspecten van het 
funchioneren van de wHO te onderzoeken. Daarbij zal het registeren in detail onder de loep worden genomen en staat in deze studie de volgende vraag centraal: wat houdt het opzetten en onderhouden van een registratie nu precies in? Het gaat daarbij niet 20 zeer om de doelstelling van een registratie - informatie veramelen ten behoeve van rationele planning - als wel om de praktijk van registreren." De vraagstelling is daarom als volgt gefomuleerd:

\section{Welk werk wordt er verricht om een registratie op te zetten en welke effecten heeft dit werk op het object van registratie, de ontwikkeling van beleld en de verhoudingen tussen bij de registratie betrokken partijen?}

Uit dergelijke vragen blijkt al dat de fundamentele veronderstelling wordt los: gelaten dat een registratie slechts een feitelijke, empirische grondslag vormt voor het daarop te baseren beleid. In de traditionele perceptuele metaforen van kennis staat de waarneming van feiten (een registratie) tegenover de politieke interventie. in deze studie wordt die metafoor losgelaten en wordt onderzacht hoe het registreren zelf een interventie kan zijn. 2

Het doel van deze studie naar de ontwikkeling van een registratie van de WHO is om meer inzicht te krijgen in effecten van registreren en zo in het functioneren van de WHO, in het bijzonder in de technische aanpak van gezondheidsproblemen en de mogelijke gevolgen daarvan voor meer politieke ontwikkelingen. De term politiek wordt hier in brede zin gebruikt en heeft zowel betrekking op de farmulering van beleidsproblemen als de verhouding tussen lidstaten.

In dit eerste hoofdstuk wordt de probleemstelling nader toegelicht. In paragraaf twee wordt ingegaan op de wijze waarop de WHO en haar critici onderscheid maken tussen wetenschap en politiek en wat het belang van dat onderscheid is voor het functioneren van de WHO.13 Vervolgens worden in de paragrafen drie en vier twee theoretische perspectieven geintroduceerd, het globaliseringsdebat en het wetenschapsonderzoek die in deze studie als voornaamste instrumenten voor de analyse van het proces van registreren worden gebruikt. In paragraaf wiff wordt de specifieke registratie geintroduceerd die in dit onderzoek object van studie is, namelik de registratie van het Human Immunodeficiency Virus of HiV. Daarbij wordt gemotiveerd waarom juist deze registratie is gekozen. Ten slotte wordt aangegeven welk empirisch materiaal de grondstof vormt van deze studie.

\section{.2 Het beeld van de WHO}

De wereldgezondheidsorganisatie (WHO) wordt in 1948 opgericht om de samenwerking tussen lidstaten ten behoeve van een betere volksgezondheid te bevorderen. De samenwerking beperkt zich tot technische zaken, zoals de opbouw van gezondheidsvoorzieningen of de ontwikkeling van internationale standaarden. ${ }^{\prime 4}$ Uiteindelijk is het doel van die technische samenwerking om de best mogelijk gezondheid voor een ieder te bereiken. De WHO hanteert bil dit alles 
een brede opvatting wan gezondheid. Gezondheid is meer dan de afwezigheid van ziekte. In de oprichtingsverklaring van de WHO wordt gezondheid gedefnieerd als de toestand van geheel fysiek, psychisch en sociaal welbevinden en niet louter de afwezigheid van ziekten of gebreken. 15

De WHO is één van de functionele organisatie wan de verenigde Naties (VN).16 De functionele organisaties van de VN zijn gericht op een bepaald terrein, zoals gezondheid (WHO), anderwijs (United Nations Educational Scientific and Cultural Organization of UNESCO) of arbeid (international Labour Organization of ULO). Deze functionele organisaties hebben tot taak om nationale staten te adviseren en te ondersteunen bif de opbouw van voorzieningen om zo de economische en sociale condities in de lidstaten te verbeteren. Sociale en economische con* dities wormen voor de VN de basis van internationale veligheid. Goede gezond. heid van de bevolking, welvaart en goed onderwijs zouden de stabiliteit tussen landen bevorderen. De relatie tussen internationale veiligheid en economische en sociale omstandigheden die in de VN-verklaring wordt gelegd, is nader geinstitutionaliseerd in functionele organisaties. ${ }^{17}$

"The United Nations Charter emerged from the ashes of de Second World War to provide a new framework for organizing international relations. It projected an international security system on the continued co-operation of the victortious powers and created a highly decentratized arrangement of functional agencies to enhance co-operation on a range of economic and social activities". is

Alleen staten kunnen lid worden van de VN en haar functionele organisaties. De verhouding tussen lidstaten is gelijk, dat wil zeggen elke lidstaat heeft één stem in de assemblee (de algemene vergadering van de VN of de gezondheidsraad van de WHO). Er wordt dus geen onderscheid gemaakt naar de contributie die een land betaalt of het aantal inwoners dat het telt. Als staten lid worden van de $V N$ blijven zij soeverein. De soevereiniteit betekent dat de VN de lidstaten nergens toe kunnen verplichten en de lidstaten alleen kan adviseren of (op hun verzoek) kan ondersteunen. "Internationaal" betekent voor de VN "inter-nationaal': samenwerking tussen staten waarbij de staten onathankelijke eenheden blijven. Deze uitleg van de betekenis van internationale samenwerking lijkt op het eerste gezicht triviaal, maar is dat zeker niet. Dat blijkt wanneer men kijkt naar andere orgamisaties waarin staten samenwerken, zoals de Europese Unie. Hier hebben internationale regelingen een veel dwingender karakter. Het Europese recht staat boven het nationale recht waardoor de soevereiniteit van staten wordt ingeperkt. De vrijblijvendheid van de regels van de VN wordt gezien als een belangrijke belemmering voor het functioneren van er onder ressorterende internationale organisaties.

De context waarbinnen internationale organisaties opereren is aanzienlijk ver. anderd. In de opbouwjaren na de tweede wereldoorlog worden liberale "laissez faire' ideeën losgelaten. In de plaats daarvan komt de overtuiging dat woor de verbetering van sociale en economische omstandigheden overheidsingrijpen nodig is. De staat wordt een centrale actor in de ontwikkeling van een nieuwe wereldorde. Tegenwoordig is het geloof in de maakbaarheid van de samenteving 
door overheidtsingripen niet goed mee voorstebaar.19 Ook is de verhouding tussen staten veranderd. Internationale conflicten zijn tegenwoordig vaker economische sociale conflicten dan mititaire conflicten. Bovendien blikt de oorzaak van intemationale conflicten veelal te liggen in conflicten binnen een staat. ${ }^{20}$ De WHO is in een aantal opzichten met de veranderende opvattingen over gezondheidsbeleid en ivternationalle siamenwerking meegegaan. Het beleid van de WHO is in de eerste jaren ma haar oprichting vooral gericht geweest op de bestrijding wan (infectie-)ziekten, maar sinds de jaren zeventig komt er in het beleid van de WHO meer aandacht voor sociale en economische omstandigheden die de gezondheid van mensen prositief of negatief beinvloeden. De brede definitie van gezondheid als fysiek, psychisch en sociaal welbevinden krijgt daarmee betekenis. Daamaast is de rol van mon-gouvernementele organisaties in het beleid van de WHO in de loop ter tijd toegenomen. Bij de oprichting van de WHO waren zulke organisaties al wel aanwezig, maar tegenwoordig is hun rol in samenwerkingsrelaties geformaliseerd. 2 .

De WHO presenteert zich als een technische organisatie. Technisch heeft betrekking op de taken die de WHO op zich neemt. De recente reorganisatieplannen die hierboven zijn aangehaald, vormen een goed voorbeeld. De drie taken van de WHO die in de reorganisatieplannen als de kernfuncties van de WHO worden aangewezen, registreren, standaardiseren en faciliteren, worden alle drie als technische activiteiten opgevat.22 Bij een technisch georiënteerde organisatie gaat het niet alleen om de taken van de WHO, en hoe zij die taken definieert, maar ook om hoe zij die taken invullt. De WHO stalat voor een rationele en instrumentele aanpak van problemen. Peabody definieert die technische benadering. van gezondheidsproblemen als volgt:

"WHO's organizational plan (...) centered on rehat theorists refer to as a rational systems model: organizations were to be instruments, designed to attain specific goals. This model assumed, that it was possible to scientifically analyze tasks (...). In 1948, not only was w the obvious structute for a technical agency to adopt, its yery chistence confirmed the agency's purpose as a newtral umbrella woth internationally exchangeable professionals, that would consistently produce regular policy divectiues and maximize healh"."23"

Een technische aanpak betekent voor de WHO ten slotte ook dat zij geen partij hoeft te kiezen. Technische kwesties zijn neutraal en a-politiek. De WHO situeert politick in deze opvatting vooral op het niveau van de verhouding tussen lidstaten. De WHO wil zich tot elke lidstaat neutraal kunnen verhouden:

"Thanks to WHO's neutral umbrella countries of differing economic status and ideological outlook joined forces to combat and overcome this disease that had sconged humanity since the dawn of ":24

Het beeld van de WHO als een technische organisatie komt op uiteenlopende manieren in de organisatie en haar werkwijze tot uitdrukking. In de eerste plaats. ziet de WHO voor zichzelf louter een coördinerende en faciliterende ral bij het 
streven naar verbetering van de gezondheid van ieder. Het opzetten van onder. zoek, het geven van onderwijs en het coödineren van programma's definieert de WHO als haar belangrijkste instrumenten. Peabody wat deze taakopwatting samen onder de noemer van het Yaws-model.25 Yaws is een ernstige en verminkende ziekte wan de huid en de botten die in de jaren zestig veelvuldig in Afrika en Azie voorkomt. De WHO gaat er vanuit dat deze ziektie effectiever kan worclen bestreden als artsen beter geïnformeerd zijn over de oorzak en behan. deling van de ziekte. Effectieve behandeling vraagt om een langwerkend antibioticum. Al in 1948 is een langwerkende penicilline ontwikkeld voor de behandeling van Yaws, maar artsen blijven veel te vaak kortwerkende penicilline gebruiken. Die kortwerkende penicilline maakt bestrijding van de ziekte duur omdat de behandeling verschillende keren moet worden herhaald. Het gevolg is dat veel patiënten helemaal miet worden behandeld.26

In de ogen van de WHO is het probleem dat bestaande wetenschappelijke kennis over de ziekte en haar behandeling niet adequaat wordt toegepast. Daarom organiseert de WHO wetenschappelijke congressen en zet zij speciale trainingen op voor artsen. 27 De WHO beschouwt zich als een neutraal doorgeefluik van kennis en ervaring en gaat ervan uit dat wanneer artsen eenmaal betere kennis hebben, zij die zullen toepassen en zo de ziekte de wereld uit helpen.

In de tweede plaats kan de organisatiestructuur van de WHO worden gezien als een manier om het technische en neutrale karakteir van de WHO uit te dragen en te bevestigen. Bij de presentatie van de organisatiestructuur wordt door de WHO steeds weer benadrukt dat elke lidstaat weliswaar een vertegenwoordiger heeft in de wereldgezondheidsraad (haar hoogste besluitvormend orgaan), maar dat deze vertegenwoorcliger daar in de eerste plaats als deskundige lid is van deze raad. De deskundigheid van de vertegenwoordigers in de wereldgezondheidsraad wordt op de voorgrond geplaatst. Dat zil ook een bepaald land vertegenwoordigen staat op de achtergrond: ${ }^{28}$

"Board members, by rule, act only in their personal capacity and overse the policy and implementation of programs".29

"Metings of the World Health Assembly and regional committes are structured to emphasize a professional atmosphere. The is allocated at each meeting for discussion of specific sechnical subjects". 30

Deskundigen die de WHO op een bepaald terrein adviseren, hebben in de organisatiestructuur een onafhankelijke positie. De leden van een technische werkgroep bijwoorbeeld behoren officieel niet tot de staf van de WHO. Voor hun werk krijgen zij alleen een onkostenvergoeding. ${ }^{3}$

De WHO komt ten derde als een technische organisatie naar voren uit de keuze voor programma"s. Pokken is voor de WHO bijvoorbeeld een idealle zirkte om haar effectiviteit bij het oplossen van problemen te demonstreren. De snelheid waarmee deze ziekte zich verspreidt is traag zodat de WHO genoeg tijd heeft om een interventie uit te voeren. Wanneer in een land een eerste geval van pokken wordt geconstateerd, heeft de WHO nog twee weken om de bevolking daar 
omheen te waccineren. Bovendien is er een effectief vaccin dat ook nog geschikt is voor gebruk in de tropen omda he buten de koelkast kan worden bewaard. Ten slotte hoeven mensen slechts ến keer te worden gevaccineerd omdat het vaccin lange tiid bescherming biedt tegen infectie. ${ }^{32}$ Kortom, het besluit van de WHO om juist de pokken de wereld uit te bannen hing nauw samen met de technische mogelijkheden die de WHO had om deze ziekte te bestrijden.

De WHO gebruikt het succesverhaal van de pokkenbestrijding om de lidstaten ervan te overtuigen dat, ondanks hun eigen goed functionerende gezondheids. zorg, een internationale organisatie meerwaarde voor hen heeft. Dankzij de uitbanning van de ziekte zijn, zo betoogt de WHO, in verschillende Europese landen de vaccinatieprogramma's stopgezet. ${ }^{3}$ In het pokkenverhaal functioneert de WHO als een technische organisatie. Het laat zien dat gezondheidsproblemen in interinational verband kunnen worden opgelost op een manier die de verhoudingen twssen lidstaten overstijgt, zonder hun nationale soevereiniteit aan te tasten. Het pokkenvaccinatieprogramma illustreert dat gezondheid kan worden verbeterd zonder politiek te bedrijven.

In de beschrijuing van de successen van het pokkenprogramma wordt door de WHO dan ook vooral de technische aanpak van problemen naar voren geschoven. In thet boek "Small Pox and its Eradication" beschrifft Frank Fenner uitgebreid en in detail de problemen bii de registratie van pokkenpatienten. ${ }^{34}$ Gegevens over de verspreiding van belangrijke infectieziekten zoals de pokken worden sinds de Internationale Hygiënische Conferentie van 1926 geregistreerd, maar als de WHO die gegevens wil gebruiken voor de planning van vaccinatie. programma's blijken ze niet te kloppen. Slechts 1 op de 100 pokkenpatiënten blijkt te worden geregistreerd. Deze onderregistratie wijt de WHO aan wederzijds wantrouwen tussen lidstaten uit vrees woor exportbeperkingen bif het bekend worden van hun aantallen pokkengevallen. On de registratie te verbeteren schakelt de WHO epidemiologen in. Op hun advies wordt besloten gegevens niet alleen via de nationale overheden te verzamelen, zoals tot dan toe gebruikelijk is, maar ook buiten de overheid om. Aan hulpverleners, die de vaccinatieprogramma's organiseren, wordt gevraagd alle pokkenpatiènten die zij in hun kliniek behandelen te melden. Daamaast worden speciale teams van deskundigen op pad gestuurd die op zoek gaan naar mensen met pokkenlittekens. Op basis van het adantal ex-pokkenpatiènten kunnen vervolgens de incidentiecijfers van zowel de overheid als de hulpverleners worden gecontroleerd.35 De WHO verklaart het onvermogen om betrouwbare gegevens te verzamelen met een verwijzing naar de politieke verhoudingen tussen staten en presenteert vervolgens de wijze waarop epidemiologen gegevens verzamelen als een oplossing woor dit probleem. Pas wanneer de registratie wordt losgemaakt wit de politieke overwegingen van overheden en in handen wordt gelegd van deskundigen kan werkelijk effectief de strijd tegen een ziekte ter hand worden genomen, aldus de WHO.

Met betrekking tot de verspreiding vam vaccins wordt in hel pokkenvaccinatieprogramma op een vergelijkbare manier getracht conflicten tussen lidstaten te omzeilen. In eerste instantie gaat de WHO er vanuit dat er voldoende vaccins 
Worden geproduceerd om wereldwijd vaccinatieprogramma's op te kunnen zetten. Weliswaar produceren niet alle landen vaccins, maar un landen wat wel vac: cins worden geproduceerd bestaan grote vooraden. Als de WHO in 1967 de intensiteit van het vaccinatieprogramma will opvoeren, bliken er intemationalal echter toch te weinig vaccins voorhanden omdat de meeste landen alleen vaccins woor hun eigen bevolking willen aanwenden. Bovendien willen landen waar een tekort is aan vaccins, geen vaccins uit andere landen gebruiken omdat zij de kwaliteit niet vertrouwen. De WHO besluit daarop om in Genève een centraal depot in te richten war alle in de wereld geproduceerde vaccins worden bewaard en waar vandaan zij worden gedistribueerd. Door een centrale opslag en de daaraan verbonden kwaliteitscontrole zorgt de WHO ervoor dat ook op het niveau van de distributie van vaccins het wantrouwen tussen landen de oplossing van medische problemen niet kan belemmeren. 36

Een programma als 'Primary Heaith Care' dat eind jaren zeventig vorm kriigt, lijkt op het eerste gezicht een breuk met de technische aanpak van de WHO. "Primary Health Care" is niet zo zeer gericht op de verbetering van gezondheidsvoorzieningen, zoals de meeste programma's van de WHO, als wel op de individuele levensstijl, de sociale of fysieke omgeving en andere soortgelijke factoren die de gezondheid van mensen beïnvloeden. ${ }^{37}$ Het programma veronderstelt dat medische kennis alleen niet voldoende is om de gezondheid te verbeteren. Hiermee komen sociaal-economische verschillen tussen de lidstaten op de agenda te staan. Toch blifft de WHO ook in dit programma vasthouden aan een technische aanpak van gezondheidsproblemen en eist de WHO dat "Primary Health Care' wordt onderbouwd met wetenschappelijk onderzoek naar de determinanten van gezondheid.

De WHO staat in haar rol als een a-politieke organisatie met enige regelmaat onder druk. In de jaren vijftig stellen een aantal belangengroepen, gesteund door enkele lidstaten, het feit ter discussie dat de WHO al lange tijd weigert om over het probleem van de bevolkingsgroei een standpunt in te nemen en zich niet will uitlaten over geboortebeperking. Onder toenemende druk van lidstaten uit Scandinavië en Azië, gecombineerd met het feit dat in steeds meer landen al een geboortebeperkingsbeleid wordt gevoerd, woelt de WHO zich uiteindelijk in 1966 genoodzaakt am rond dit thema belleid te ontwikkelen. De WHO vermijt ook dan om een standpunt in te nemen in de discussie over geboortebeperking en vermijdt daarmee politiek gevoelige uitspraken die de verhouding tussen de lidstaten onder druk kan zetten. Zij doet dit door het probleem van de bevolkingsgroei als een puur medisch probleem te herformuleren, namelijk als een gezondheidsrisico voor vrouwen. 3.8 Als de WHO in de jaren zeventig een onderzoeksprogramma opzet voor de ontwikkeling van antivruchtbaarheidsvaccins wermijdt de WHO eveneens om uitspraken te doen over de politiek gevoelige relatie tussen bevolkingsgroei en ontwikkelingslanden door geen onderscheid te maken in potentiële gebruikers van het vaccin. Een vaccin is, zeker als het slechts eenmaal hoeft te worden toegediend en buiten de koelkast te bewaren is, geschikt voor gebruik in ontwikkelingslanden. Door de technische vereisten waaraan het vaccin moet voldoen op de voorgrond te plaatsen, laat de WHO 
Impliciet voor wie de vaccins ontwikkeld worden. ${ }^{39}$

Ook rond andere thema's is de WHO verweten te veel uit te gaan van een medisch model vain ziekte en sterfte waardoor er te weinig, aandacht is voor de sociale economische omstandigheden die tot gezondheidsproblemen kunnen leiden. Critici adviseren de WHO daarom om minder artsen en meer andere deskundigen in dienst te nemen 40 Zo'n oplossing voor de problemen van de WHO beves. tigt echter het zelfbeeld van de WHO als een technische organisatie want ook in de ogen van critulci blift de WHO een organisatie van deskundigen. De veranderstelling dat de inzet van deskundigen het belangrijkste instrument is van de WHO wordt als vanzelfsprekend overgenomen, zonder de vraag te stellen wat kennis en techniek is en of de aanpak wan de WHO inderdaad puur technisch is. Het onderscheid tussen wetenschap en politiek dat in de taakopvatting, de organisatie en de activiteiten van de WHO centraal staat, wordt door veel criticil overgenomen en darmee bevestigd.

"The world needs a strong body to take the lead in heallh matters, to act as an advocate for equity in economic and social development, wo set priorities for the use of liwnited resources, to provide neutral territory for debating sensitive isstes and to give technical adrice and support". 41

In dit boek wordt dit beeld van de WHO aan een mader onderzoek onderworpen. Is het inderclaad zo dat de WHO de a-politieke en technische organisatie is zoals zij zichzelf voorstelt en zoals ze door haar critici wordt voorgesteld? Als dit niet zo is, hoe kunnen we het werk dat de WHO verricht dan begrijpen en wat zegt dit over de wijze waarop kennisorganisaties als de WHO functioneren? Kennisorganisaties zijn niet zo zeer organisaties die kennis ontwikkelen, zoals universiteiten of onderzoeksinstituten als wel organisaties waarin kenniskwes. ties als waarheld en objectiviteit vormend zijn. Karin Knorr-Cetina spreekt over kennisorganisaties als organisaties waarin kenmiskwesties zich hebben ingenesteld. ${ }^{42}$ Om de bovengenoemde vragen te beantwoorden wordt de blik, in plaats van op het zelfbeeld en de doelstellingen, wooral gericht op de praktijk van de WHO. Dat wil zeggen het concrete werk dat de WHO verricht. Bij de term 'werk' kan men denken aan vergaderingen van commissles van de WHO, rapporten die worden geschreven en de opbouw valn voorzieningen.

Om het werk van de WHO in deze zin te kunnen analyseren wordt in dit onderzoek gebruik gemaakt van twee theoretische perspectieven, namelijk concepten uit de figuratiesociologie en uit het wetenschapsonderzoek. Het eerste instrument wordt ingezet in het globaliseringsdebat en geeft een interessant sociologisch perspectief op de rol van de WHO in de vorming van een wereldorde. Met de inzichten uit het wetenschapsonderzoek kan de rol van wetenschappelijke kennis in het functioneren van de WHO worden onderzocht.

In de volgende twee paragrafen worden deze perspectieven geintroduceerd. in deze paragrafen worden de concepten beschreven die voor de analyse van de ontwikkeling van de registratie worden gebruikt. Ook wordt uiteengezet hoe deze perspectieven in samenhang kunnen worden gebruikt. 


\section{.3 Internationale organisaties in het globaliseringsproces}

In het onderzoek naar internationalisering is de doelstelling wan de WHO en de andere organisaties van de WN valak als uitgangspunt genomen. De WHO is een internationale organisatie die tot doel heeft de samenwerking tussen de lidstaten te bevorderen om de gezondheid van mensen over de hele wereld op een zo hoog mogelijk niveau te krijgen. Internationalisering wordt meestal gelijk gesteld aan samenwerking tussen staten. In het globaliseringsdebat wordt die vereenzelviging van internationalisering met samenwerking tussen staten ter discussie gesteld. Daarmee wordt ook een nieuw perspectief op internationale organisaties mogelijk.

In sociologisch onderzoek naar globalisering staan vooral de betrekkingen tussen individuen en organisaties over nationale grenzen heen centraal. Globalisering heeft te maken met de schaal warop mensen en organisaties in de afgelopen decennia zijn gaan functioneren. De schaalvergroting die daarin heeft plaatsgevonden heeft het aantal afhankelijkheidsrelaties tussen mensen exponentieel vergroot.

Producten die in een gewone supermarkt worden verkocht komen uit de hele wereld. Consumenten in Nederland kopen sperziebonen die enkele dagen eerder door Keniaanse boeren zijn geplukt, en via een reeks schakels in de groenteafdeling zijin terechtgekomen. Vakanties naar bestemmingen die vroeger een expeditie vereisten, zijn nu te koop bij het reisbureau op de hoek. Amerikaanse artsen transporteren hun medische rapporten on-line naar India, waar ze door goedkope typisten warden uitgewerkt. 's Avonds worden ze in Amerika weer van het computernetwerk gehaald. Ondernemingen als Kentucky Fried Chicken, MacDonald's of Coca Cola venten hum waren over de hele wereld uit. Dit zijn enkele voorbeelden van een proces dat meer en meer aangeduid is als "globalisering'. Globalisering is een breed concept dat staat voor die uitbreiding wan transacties over grote afstanden, het groeiend aantal afhankelijkheidsrelaties tussen mensen wereldwijd en de groeiende betekenis van internationale onderne. mingen en -organisaties.43

Wat zijn de effecten wan dit globaliseringsproces? Onderzoekers die zich met dergelijke processen hebben beziggehouden verschillen nog al eens van mening in hun antwoord op die vraag. Dit wordt wel aangeduid als het globaliseringsde. bat. Aan de hand van de vraag naar de effecten van globalisering wordt in deze paragraaf eerst in grote lijnen dit globaliseringsdebat geintroduceerd.44 Vervolgens wordt nader ingegaan op de discussie over de verschillen tussen een internationaal en een transnationaal perspectief. Met het concept transnational netwerk kan vervolgens afstand worden genomen van ogenschijnlikk vanzelf. sprekende veronderstellingen over de rol van de WHO als een internationale organisatie en kan de WHO vanuit een ander perspectief wordien onderzocht.

\section{Homogenisering versus hybridisering}

De auteurs die deelnemen aan het globaliseringsdebat vallen grofweg in twee groepen uiteen: onderzoekers die menen dat globalisering leidt tot homogeni- 
sering en zif die het omgekeerde betogen en willen laten zien hoe globalisering leidt tot hybridisering.

George Ritzer is eer vertegenwoordiger van de opwatting dat globalisering primair leidt tot homogenisering. In een belangrijke bijdrage aan het globalise. ringsdebat spreekt hil van de MacDonaldisering van de samenleving. ${ }^{45}$ MacDonalds, zo betoogt Ritzer, heeft in bijna alle steden van de wereld restaurants geopend en laat er zich op woor staan dat in al die vestigingen het eten dezelfcle kwaliteit en smaak heeft; overal ter wereld zijn de hambitrgers van MacDonalds even groot en even lang gebakken; overal zien de vestigingen er hetzelfide uit.

Ritzer"s beschouwing wan homogenisering is verbonden met een oordeel over het proces van globalisering. Homogenisering is in de ogen van Ritzer geen goede ontwikkeling. MacDonalds is een voorbeeld van de manier waarop het streven naar een efficiente, voorspelbare en berekenbare productie kan doorschieten. Een onvermijdelijk gevolg daarvan is dat ook een persoonlijke uitdrukking als een glimlach word gestandaardiseerd en dat de mogelijkheden voor een individu om werk op een eigen manier in te vullen tot nul worden gereduceerd. In het perspectief van Ritzer wordt globalisering via homogenisering een uitwas van madernisering.

Mike Featherstone, Ulf Hannerz en Abraham de Swaan brengen echter naar voren dat die vrees voor homogenisering ongegrond is.46 De stelling van Ritzer is volgens hen een artefact van zijn gebrekkige aandacht voor interacties tussen mensen. Daardoor ontstaat de indruk alsof de ontwikkelingen zich achter de rug van mensen om voltrekken en zij daar geen imvloed op hebben. Antropologische studies naar het gebruik van massagoederen laten echter zien hoe die in de han* den van mensen veranderen, omdat zij de producten ook op een andere manier of voor een ander doel gebruiken. ${ }^{77}$ Signe Howell beschrifft hoe een Coca Cola flesje op Zuid Ruykus een symbool van vruchtbaarheid is geworden omdat de vorm van de fles lijkt op het lichaam van een zwangere vrouw 48 Diezelfde colaflesjes worden in India leeg op de hoedenplank van de auto gelegd om $z 0$ anderen hun rijkdom te laten zien. In dit perspectief leidt globalisering niet tot homogenisering maar tot hybridisering. Vermenging en aanpassing leiden tot nieuwe cultuuruitingen. Er komen nieuwe muziekgenres, andere keukens, enzovoort.

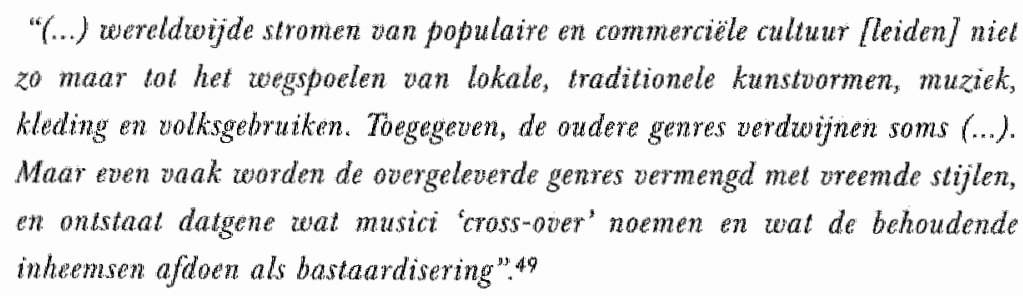

De analyse van het proces van globalisering in temen van hybridisering is verbonden met een positievere beoordeling van deze ontwikkeling. Hybridisering, zo betogen Hannerz en Featherstone, creëert nieuwe mogelijkheden en daarmee nieuwe kansen. 30 


\section{Transnationale netwerken}

Bimen het globaliseringsdebat wordt een discussie gevoerd over de vraag of en zo ja, welke rol nationale staten spelen in het proces van globalisering. Opvattingen daarover zinn relevant voor ons denken over de rol van de WHO als een internationale organisatie. De WHO heeft immers tot doel om de internationalisering van gezondheidsbeleid te realiseren door de samenwerking tussen staten te bevorderen. Het perspectief op de WHO zal veranderen wanneer blikt dat nationale staten een heel andere rol spelen op het globaliseringstoneel dam waar de WHO van uitgaat.

Er zijn minstens drie redenen om de prominente rol van de nationale staat in internationale samenwerking te relativeren. Ten eerste is een wereld verdeeld in naties slechts een tijdelijke historisch bepaalde ordening van de wereld. Er zijn tiijen geweest zonder staten, maar met bloeiende internationale contacten. Dergelijke contacten waren er tussen pelgrims, koningshuizen en geleerden voordat nationale staten bestanden.5/ In onze eigen tijd ziem we om ons heen de mogelijke tijdelijkheid wan de nationale staat. Naties in onder andere Afrika en Oost-Europa dreigen aan het einde van de twintigsite eeuw uit ellkar te vallen. Ten tweede krijgen zogenaamde non-gouvernementele organisaties (NGO's) zoals het Rode Kruis of Artsen Zonder Grenzen, een steeds belangrijkere rol in internationale samenwerking vooral omdat zij goed in staat blijken om de sociaaleconomische condities in landen over de hele wereld te verbeteren.52 zoals in de tweede paragraaf van dit hoofdstuk reeds is opgemerkt, heeft de WHO haar uitgangspunten ten aanzien van de samenwerking met NGO's bijgesteld. Bij de oprichting van de WHO waren NGO"S wel aanwezig maar hadden zill geen recht van spreken. Nu heeft de WHO tall van officiële samenwerkingsrelaties met NGO's. De derde reden is echter de belangrijkste. Aantoonbaar is dat langs andere wegen dan via internationale organisaties en - verdragen banden tussen mensen worden aangehaald. Daarbij kan worden gedacht aan de manier waarop multinationale bedrijven functioneren, aan de manier waarop de moderne toeristenindustrie werkt, of aan het functioneren van communicatiemedia als film, televisie en internet..$^{53}$

Om de minder prominente rol van de nationale staat als centrale actor in het proces van globalisering te benadrukken is de tem "transnationaal" geintrodu. ceerd. Transnationaal wordt gedefinieerd als:

"It [transnational] makes the point that many of the linkages an question are not "international", in the strid sense of involung nations - actwally, states as corporate actors. In the transnational arena, the actors may now be individuals, groups, movements, business enterprises".54

Vanuit een transnationaal perspectief staan andere actoren voorop in het proces van globalisering dan vanuit een traditioneel intemationaal perspectief. Dat houdt in dat het onderzoek naar transnationale relaties ook aandacht heeft voor andere soorten verbindingen dam internationale verdragen waarin afspraken tussen overheden zijn vastgelegd. Men kijkt naar zaken alls de effecten van telefonische contacten tussen familieleden en vrienden die in verschillende landen 
wonen. Andere voorbeelden van zuke transmationale verbindingen zijn de stromen e-mails, de relaties tussen talen, het reizen van wetenschappers en technisch adviseurs, migratiebevegingen en toerisme 55

In "De sociologische studie wan de transnationale samenteving" brengt Abraham de Swaan de discussie over het groelend aantal transnationale relaties in verband met sociologische theorievorming over veranderingen in de afhankelijkheidsrelaties tussen mensen.56. Tegelijkertijd plaatst De Swaan de ontwikkeling van "transnationalle netwerken" in een lange terminperspectief op de ontwikkeling van de samenleving. Volgens De Swaan zijn de afhankelijkheidsrelaties die mensen in een samenleving met elkaar verbinden zowel extensiever, intensiever, enkelwoudiger als ingewikkelder geworden.57 Hij bedoelt daarmee dat in de tegenwoordige samenleving bindingen tussen mensen veel verder reiken (extensiever) en dat elk knooppunt in het relatienetwerk meer mensen met elkaar verbindt (intensiever). Het kleine, besloten, volledig en veelvoudig verbonden netwerk van weleer is opengevouwen. Er zijn meer contacten met de buitenwereld gekomen en binnen het netwerk vallen verbindingen weg of verliezen hun veelwoudige functies (enkelwoudiger). Mensen kunnen hum afhankelijkheidsrelaties wiet meer overzien met als gevolg dat hun handelen vaak heel andere gevolgen heeft dan zij bedoelen (ingewikkelder).

Vanuit dit historisch sociologisch perspectief is De Swaan geinteresseerd in enerzijds de ontwikkeling in bindingen tussen mensen over nationale grenzen heen en anderzijds de ombedoelde effecten, de eigen dynamiek van deze transmationale netwerken.

"De traxsnationale samenleving vertown een geheel eigen orde en dynamiek, een relatieye autonomie, niet alleen ten opzichte wan de samenstellende netwerken van nationale samenlevingen en transnationale markten, maar ook ten opzichte van de deelnemende actaren: staten, transnationale bedrijwen en organisaties". 58

Volgens De Swaan kan het proces van globalisering het best worden onderzocht door het patroon van verhoudingen te beschrijuen dat mensen bindt over nationale grenzen heen en in samenhang daamee de instituties, die instrumenteel zijn bilj de vorming van zulke netwerken. 59 Daarmee wordt vermeden dat sociologische begrippen die ooit bedoeld waren om nationale samenlevingen te onderzoeken worden geêxtrapoleerd naar een analysekader voor de transnatio. nale samenleving. Bovendien wordt voorkomen dat onderzoek naar globalisering zich louter beperkt tot culturele aspecten zoals dat, volgens De Swaan, in veel onderzoek naar globalisering gebeurt.

Een mooi voorbeeld wan onderzoek naar de ontwikkeling wan transnationale netwerken noemt De Swaan de studie van Benedict Anderson "Long Distance Nationalism" " "60 Anderson heeft onderzocht in welke opzichten de transnationale netwerken van enerzijds emigranten in de zeventiende eeuw en anderzijds gastarbeiders in de twintigste eeuw onderling verschillen en will zo verklaren hoe de betekenis van het nationalisme en de positie wan de staat in de loop der tijd is veranderd. Zijn stelling is dat nationalisme juist word gevoed door mensen 
die hun land hebben verlaten: bannelingen, emigranten en gastarbeiders. Voor deze mensen is de band met het land van herkomst niet vanzelfsprekend zodat die band actief vorm wordt gegeven.

Dergelijke banden zijn in de loop der tijd aan verandering onderhevig. in de zeventiende eeuw hebben emigranten eenvoudigweg geen contacten meer met familie die in hun geboorteland is achtergebleven. De afstand kon gewoon niet worden overbrugd. Onderling hebben de emigranten wel contact en zo houden zij voor zichzelf hun nationale taal en cultuur in stand.

In de twintigste eeuw kunnen emigranten en later gastarbeiders dankzij steeds. beter wordende communicatiemiddelen, zoals telefoon of telex en dankzil de groei van transportmiddelen, vooral vliegverbindingen, wel contact houden met famillie en vrienden. Daardoor gaan transnationale gemeenschappen en culturen ontstaan. Door de interactie binnen die gemeenschappen hebben emigranten en gastarbeiders nu ook invloed op gebeurtenissen in thet moederiand. Zij kumnen hum nationalistische gevoelens ondanks de afstand thuis laten gelden, bijvoor. beeld door politieke groeperingen te steunen. Anderson noemt Amerikaanse leren die met veel geld het vredesproces in Noord-lerland steunen. Transnationale relaties hebben, concludeert Anderson, de betekenis van het nationalisme en van de staat veranderd: de staat is geen eenheid van cultuur meer.

In zijn boek laat Anderson ook zien dat de nationale cultuur verschillende vormen aanneemt, verbonden met veranderingen in sociale netwerken. Als voorbeeld geeft hij een gastarbeider uit Peloponnesus in Duitsland, die als herinnering aan Griekenland een poster van Lufthansa aan de mur heeft hangen met daarop een afbeelding van het Parthenon. Als zijn vader zou zijn geëmigreerd zou die in plaats van zo'm poster familiefoto's aan de muur hebben hangen. Voor de emigrant uit het verleden wordt Griekenland verbeeld door een portret van zijn individuele relatie met bloedverwanten, voor de hedendaagse gastarbeider door een 'icoon' van de Griekse cultuur uitgegeven door een transnationale luchtvaartmaatschappii die de gastarbeider in enkele uren terugbrengt naar zijn ach. tergebleven familie, waraan de emigrant in het verleden alleen herinneringen had.

Volgens De Swaan zijn internationale organisaties bij uitstek de plek war de ontwikkeling van transnationale netwerken kan worclen onderzocht. of In een internationale organisatie kunnen namelijk de relaties worden onderzocht tussen de internationale staf en haar netwerk met experts en de ambtenaren van nationale regeringen. Zulke netwerken ontwikkelen volgens. De Swaan eeri eigen momentum warin hoge functionarissen posities innemen die verder strekken dan de aan hen toevertrouwde nationale belangen. Hoewel afgevaardigd als vertegenwoordiger van een land gaat de deskundige nieuwe verbanden aan en gaat daarmee deememen in netwerken die dwars door staten dan wel naties heenlopen. Deze nieuwe afhankelijkheidsrelaties veranderen op hun beurt het karakter van de nationalle staat en haar rol op het wereldtoneel. Volgens De Swaan hebben dergelijke netwerken, en niet de nationale staten sec, bijgedragen aan de verbreiding van bijvoorbeeld het ethos van de preventieve gezondheidszorg zoals de WHO dit voorstaat. 
Het globaliseringsdebat, en met name de discussie over de ontwikkeling van transnationale relaties, maakt het mogelijk om afstand te nemen van de zo vanzelfsprekende uitgangspunten van de WHO. In plaats van de WHO te beschou wen als een internationale organisatie, wordt de WHO onderzocht als drager van transmationale netwerken. Dat betekent dat nilet alleen wordt gekeken naar de relaties tussen de WHO en haar lidstaten, maar ook naar de relaties van de WHO met bijvoorbeeld onderzoeksinstituten en individuele burgers.

\section{.4 De opbouw van wetenschappelijke netwerken}

On te onderzoeken op welke manier kennis en wetenschap binnen de WHO functioneren en hoe die zich verhouden tot haar beleid, wordt in dit onderzoek te rade gegaan bil de resultaten van het wetenschapsonderzoek.

Het wetenschapsonderzoek is in de jaren zeventig tot ontwikkeling gekomen rond de vraag welke invioed sociale posities hebben op de ontwikkeling van wetenschappelijke kennis. In klassieke filosofische opvattingen over wetenschap wordt ervan uitgegaan dat alleen de feiten, zoals waargenomen door objectieve onderzoekers, de gang van kennis bepalen. Wanneer belangen of politieke opvattingen binnen de wetenschap in het geding komen, leidt dat meestal tot het falen van wetenschap. Vroege wetenschapsonderzoekers als David Bloor, Barry Barnes en Donald Mackenzie proberen dit kader te doorbreken en latem in hun werk zien hoe ook succesvolle theorieën en onderzoeken door sociale factoren zijn gekleurd. $6 z$

Eind jaren zeventig verschuift de aandacht in het wetenschapsonderzoek van politieke invloeden naar onderzoek naar het dagelijks functioneren van laboratoria en het, werk dat wetenschappers daar moeten werrichten om feiten te 'produceren'. Het werk in laboratoria komt model te staan voor een constructivistische opvatting over wetenschap. Zo'n opvatting is onder andere uitgewerkt door Bruno Latour en Steve Woolgar.6.3 De essentie wan het werk in laboratoria is dat objecten uit hun normale context worden gehaald en op een nieuwe manier bij elkaar worden gebracht. ${ }^{64}$ Een virus wordt bijvoorbeeld verzwakt, waarna het gebruikt wordt om de vorming van antilichamen in het bloed te stimuleren. Het verandert zo van een ziekteverwekker in een vaccin.

Een ander opvallend aspect van werk in het laboratorium is dat alle daar voopkomende zaken niet alleen met elkaar zịin verbonden, maar zijn verankerd in een uitgebreid extern netwerk. De apparatuur, de data die een experiment genereert, het tijdschrift waar een artikel naartoe wordt gestuurd, de monsters die in een experiment worden gebruikt, het medium dat voor celkweek wordt ingezet, de onderzokers en technici, allen maken deel uit van een enorm netwerk. Knip étn of enkele draden door en het labaratorium produceert niet langer kennis, maar op zijn best onbewezen speculatie. ${ }^{55}$ Latour heeft, samen met Callon dit gegeven theoretisch nader vormgegeven in de actor-netwerk-theorie. ${ }^{66}$ De voor deze studie belangrikste elementen daaruit kunnen het best worden uiteenge- 
zet door in te gaan op twee door Latour onderstheiden opwattingen over de ontwhkeling van wetenschap: het diffusiemodel tegenover het thanslatiemodel.s:

\section{Diffusie en translatie}

Het diffusiemodel van de onwikkeling wan wetenschap sluit aan bij de standaardopvatting van wetenschap en gaat uit wan een heldere scheidslijn tussen wetenschap en maatschappij; kennis ontwikkelt zich binnen de wetenschap via waarneming en theorievarming en wordt vervolgens ioegepast in de maatschappij. Latour spreekt van een diffusiemodel omdat de vergaarde wetenschappelijke kennis als vanzelf klaar is voor verspreiding in de samenleving. Eën van de grondaannames voor die vanzelfsprekendheid is het idee dat wetenschappelijke kennis gelijk is aan ware kennis. Niemand kan om de waarheid heen en dat verktaart de diffusie wan wetenschap in de samenleving. ${ }^{\circ}$

In het translatiemodel staat juist het werk voorop dat wetenschappers moeten verrichten om wetenschappelijke kennis te produceren en feiten waar te maken. Wetenschappers zijn volgens Latour vootturend in de weer om ervoor the zorgen dat anderen hun beweringen accepteren. Zij proberen die beweringen ster ker c.q. geloofwaardiger te maken dan die van anderen. Onderzoekers doen dat door die beweringen te koppelen aan zoveel mogelijk uiteenlopende elementen in hun omgeving. Daarbij gaat het om theorieën, de resultaten van eerder onderzoek, instrumenten, toepassingen en maatschappelijke ontwikkelingen.69 Wetenschappelijke uitspraken worden, doordat ze ingekapseld zijn in een dik weefsel wan relaties met andere kenniselementen, harder dan andere uitspraken; iemand die een wetenschappelijke uitspraak ter discussie wil stellen, moet niet alleen de onderzoeker overtuigen van zijn ongelijk maar ook gevestigde theorieën, geavanceerde laboratoria, het gebruikte instrumentarium en vele andere onderzoekers. Kortom een goede wetenschappelijke uitspraak heeft een heel netwerk wan bondgenoten dat alleen met een geweldige inspanning omver kan worden gelopen. Wetenschappelijke kennis onderscheidt zich volgens Latour dan ook niet van andere soorten kennis door de methode wan dataverzameling, een theoretische bril of de onathankelijke positie, maar door het vermogen van wetenschappers om talrijke heterogene elementen aan elkaar te verbinden en zelf als woordvoerder op te treden.

Dergelijke netwerken worden in de loop der tijd door legers van onderzoekers gebouwd. In de opbouw ervan worden wetenschappelijke claims niet alleem hapder, maar verandert ook de inhoud enan. De bondgenoten die de wetenschapper nodig heeft om zijn uitspraak harder te maken, laten die uitspraak zelden ongemoeid. Zij interpreteren de ütspraak biivoorbeeld op een andere manier of gebruiken de uitspraak voor een ander doel.

Een voorbeeld. In 1909 ontwikkelt Paul Ehrlich in een laboratorium een genees. middel tegen syfilis. Getest op cavia's blijkt het middel effectief. Het komt op de markt, maar in handen van artsen verandert het geneesmiddel in een dodelijke injectie. Het is Ehrlich weliswaar gelukt om de artsen te interesseren voor zijn geneesmiddel, maar de artsen gebruiken het vervolgens voor andere ziekten en in een andere dosering dan Ehrlich voorschrifft. In plaats van genezen syfilispa. 
tênten waren er nu dodelijke slachtoffers en een enorm schandaal. Dit voorbeeld laat zien hoe op de weg van het laboratorium naar de praktiik zowel het geneesmiddel (de dosis), de werking (effectiviteit), de patienten en het handelen van artsen veranderen. 70

Latour spreekt in deze context over de translatie van kennis, waarbij translatie zowel een verandering in richting (verplaatsen) als een verandering van inhoud betekent. Het verplatsen van kennis gaat miet zonder veranderingen in de inhoud ervan. Het translatiemodel wijst ook de traditionele scheiding van wetenschap en samenleving af. Deze zijn volgens Latour innig met elkaar verweven, want wetenschappelike kennis wordt pas waar gemaakt als die ingebed raakt in de samenleving en in dat proces verandert zowel de inhoud van kennis als de maatschappelike bindingen. Latour heeft zijn ideeën over de verwevenheid tussen wetenschap en samenleving uitgewerkt aan de hand van een beschrijving van het werk van Louis Pasteur bij de ontwikkeling van een vaccin tegen miltvuur bij koeien. In de negentiende eeuw ontwikkelt Pasteur in zijn laboratorium een vaccin dat de bacterien die miltwuur veroorzaken de baas is. De bacteriën kunnen in het laboratorium verslagen worden. De volgende stap is om thet vaccin te verplaatsen van het laboratorium naar boerderijen. Daar worden immers de koeien bedreigd met miltvuur. Latour beschrijft hoe Pasteur de boerderijen verbouwt tot labaratoria. Om het vaccin te laten werken wordt het netwerk van apparaten en handelingen dat is opgebouwd in het laboratorium uitgebreid tot in de boerderijen waar koeien worden gevaccineerd.

De inzichten uit het wetenschapsonderzoek bieden mogelijkheden om het zelfbeeld van de WHO nader te onderzoeken. Terugkijkend naar het zelfbeeld zoals dat in paragraaf twee is beschreven, wordt in het zelfbeeld van de WHO uitgegaan wan het diffusilemodel. De WHO presenteert zichzelf als een neutraal doorgeefluik van kennis die in de wetenschap is ontwikkeld. Het zogenaamde Yawsmodel is daarvan een goed voorbeeld. Daarin wordt immers verondersteld dat als artsen in kenmis worden gesteld van de nieuwste medicijnen zil die vanzelfsprekend zullen gaan gebruiken. Volgens Latour is het difusiemodel wel geschikt om het resultaat van de opbouw vam wetenschappelijke netwerken te beschrijven, maar niet om inzicht te krijgen in het werk van wetenschappers om zulke netwerken op te bouwen. Dat geldt ook voor de registratie die onderwerp is van deze studie. Wanneer al het werk is verricht, lijkt het alsof er van meet af aan harde feiten zijm verzameld die ten slotte in een logische database zijn terechtgekomen. Al het werk dat moest worden verricht om zover te komen wordt onzichtbaar gemaakt. Wanneer de ontwikkeling van een registratie met behulp van het translatiemodel wordt onderzacht, kan dit werk zichtbaar worden. Dan wordt ook duidelijk hoe de WHO zelf bijdraagt aan de ontwikkeling van kennis en niet alleen maar een doorgeefluik is van kant en klare (afgeronde) kemis. Latour heeft een bijzondere interesse voor registraties. Registraties zijn woor hem het ultieme voorbeeld om te laten zien hoe wetenschappelijke kennis c.q. een netwerk wordt opgebouwd. Het proces van registreren beschrijft Latour als mobiliseren. stabiliseren en combineren. Als voorbeeld geeft hij de reizen aan die 
zoölogen in de negentiende eeuw naar Amerika en Afrka maken. Op de terug. reis nemen zoölogen kaarten, planten en dierenmee. Zooblogen kunnen onmogelijk hele gebieden mee naar huis nemen en maken de flora en fauna mobiel door grondmonsters te nemen, dieren te vangen en planten uit te graven. Voor het mobiliseren wordt echter een prijs betaald: de dieren sterven in het ruim van het schip en verrotten voordat het schip weer in de thuishaven is. Om thuis verzamelingen wan dieren en planten uit verre landen aan te kunnen leggen, die. nen zij ook te worden gestabiliseerd. Zoölogen krijgen op hun volgende reizen instructies mee hoe zij de dieren en planten kumen conserveren. Daarbil gaat het er niet alleen om te voorkomen dat de planten en dieren gaan rotten, maar ook om de mogelijkheid open te houden om terug te gaan naar de oorspron. kelijke plaats van de planten en de dieren. Stabiliseren maakt het mogelijk om tussen de verzamelde planten en dieren (de verzameling of de registratie) en het oorspronkelijke object (het bos) heen en weer te bewegen zonder extra verval, aantasting of vervorming. De winst wan het aanleggen van verzamelingen (of het opzetten van registraties) schuilt in het combineren. Dankzil de mobilisatie en stabilisatie van de flora en fauna kunnen zoölogen in natuurhistorische musea of andere plaatsen waar monsters, kaarten en formulieren worden opgeslagen, in een klein aantal stappen de hele wereld over reizen door enkele laden open te trekken. Als onderzoekers voor het eerst zoveel verschillende dieren en planten tegelijkertijd onder ogen zien, is het geen wonder dat zij nieuwe dingen zien. De concepten mobiliseren, stabiliseren en combineren worden in deze studie gebruikt om het werk in kaart te brengen dat wordt verricht om een registratie op te zetten (zie vooral hoofdstuk 3). Ook andere wetenschapsonderzoekers hebben zich bezig gehouden met de ontwikkeling van registraties. Bowker en Star hebben aan de hand van een studie naar de ontwikkeling van de Internationale Classificatie van Doodsoorzaken (ICD) van de WHO de effecten van classificeren en standaardiseren onderzocht. ${ }^{71}$ Bowker en Star beschrijven het netwerk dat is opgebouwd voor de Internationale Classificatie van Doodsoorzaken. In plaats van 'netwerk" gebruiken zij het con* cept infrastructuur omdat zij de technische en materiele aspecten willen benadrukken. In hun analyse willen zij de verwevenheid laten zien tussen enerzijds de ontwikkeling van standaarden en andere infrastructurele voorzieningen en anderzijds de ontwikkeling van kennis en politiek. Zij hebben daarvoor het concept infrastructurele inversie geintroduceerd. In studies naar de ontwikkeling van kennis en politiek, zo betogen Bowker en Star, dienen infrastructurele voorzieningen, die meestal op de achtergrond staan op de voorgrond te worden geplaatst. Het door hen ontwikkelde perspectief op infrastructurele voorzieningen, wordt in deze studie ingezet om de rol van de WHO nader te bezien (zie hoofdstuk 2). De WHO plaatst de infrastructurele voorzieningen die zij opbouwt, juist op de achtergrond; de WHO wil ook de ontwikkeling van onderzoek en beleid faciliteren zonder daar inhoudelijk een stempel op te drukken. Bowker en Star problematiseren de veronderstelde neutraliteit wan infrastructurele voorzieningen. 


\section{Sociologie en het wetenschapsonderzoek}

Met concepten ut het globaliseringsdebat kan inzicht worden verkregen in de dynamiek en logica van wereldwijde netwerken warmee een nieuw perspectief kan worden ontwikkeld op internationale organisaties. Terwill in de meeste studies over de globalisering van de volksgezondheid en de rol van de WHO daarin, de keuze van programma's centraal staat thoe pakt de WHO globale gezondheidsproblemen aan) is deze studie gericht op de transnationale bindingen die binnen de programma"s van de WHO worden opgebouwd. ${ }^{72}$ De ideeên en concepten ut het globaliseringsdebat worden dit keer miet ingezet om de problematiek te beschrijven waarmee de WHO in de toekomst mogelijk geconfronteend zal worden, maar om de rol van de WHO in het globaliseringsproces te onderzoeken. Onderzocht wordt hoe binnen de WHO transnationale bindingen vorm krifgen en wat het effect van die bindingen is op het onderzoek en het beleid op het gebied van de internationale volksgezondheid.

Het globaliseringsdebat biedt weinig aanknopingspunten om de rol van kennis, die woor het functioneren wan de WHO zo'n belangrijk is, te onderzoeken. Onderzoekers van globalisering richten zich vooral op economische en culturele netwerken terwijl wetenschappelijke netwerken bij uitstek een internationaal karakter hebben, denk aan het internationale verkeer via tijdschriften, congressen en uitwisselingen van onderzoekers en studenten. Studies naar globalise ring gaan over de opkomst van wereldmuziek, internationale keukens, het leven wan immigranten, multinationals, wereldsteden, maar zelden over wetenschap. ${ }^{37}$ De reden waarom zo weinig aandacht is voor wetenschappelijke praktijken in het globaliseringsclebat is dat de sociologische visie die op culturele, maatschappelijke en economische processen is ontwikkeld niet wordt doorgetrokken naar de ontwikkeling van wetenschap. Er wordt veelal vanuit gegaan dat weten. schap een activiteit is die rationeel verloopt en door feiten wordt gestuurd, zodat het soort sociale processen die globalisering kenmerken er niet relevant voor zijn. Latour beschrijt de ontwikkeling van wetenschappelijke kennis als de opbouw van een (heterogeen) netwerk. De specifieke dynamiek van wetenschappelijke transmationale netwerken blift voor onderzoekers op het terrein van globalisering verborgen. In het wetenschapsonderzoek zijin bijvoorbeeld, dankzij de vele studies die zijin gedaan naar de ontwikkeling van kennis en techniek, concepten ontwikkeld om de rol van niet-menselijke actoren (dingen) in de opbouw van netwerken te onderzoeken. Ook is onderzocht hoe weterschappelijke netwerken zich onderscheiden van andere netwerken; in wetenschappelijke netwerken worden de ellementen zo geordend dat de een de ander kan vertegenwoordigen en de elementen samen een sterke keten vormen (zie paragraaf 4). Om een organisatie als de WHO waarin zowel aspecten wan globalisering als ook van kenmisontwikkeling centraal staan beter te begrijpen, is kortom een werbinding van sociologische begrippen die in het globaliseringsonderzoek worden ingezet met het constructivistische begrippenkader wan het wetenschapsonderzoek vruchtbaar.

Het is in dit onderzoek niet miin bedoeling om theoretische concepten uit de figuratiesociologie en het wetenschapsonderzoek te integreren. Ik gebruik con- 
cepten uit beide tradities naast elkaar; zij wullen elkaar aan. Een voorbeeld van eerr onderzoek war concepten uit het wetenschapsonderzoek en de sociologie naast elkaar worden gebrukt is de studie van Sjaak Koenis "Het verlangen naar Gemeenschap. Over moraal en politiek in Nederland na de verzulling". " Hij hicht zich op een debat dat al emige tijd in de sociologie wordt gevoerd over het belang van gemeenschappelike normen en waarden als de bindende elemen. ten in de samenleving. Achtergrond van dit debat is een politieke discussie over de ontwikkeling van de nationale identiteit die wordt uitgelok: door het verdwijnen van nationale grenzen als gevolg van enerzijds de Europese eenwording en anderzijds integratieproblemen van immigramten en asielzoekers. Het debat spitst zich toe op de vraag of de sociale cohesie in de samenleving door deze ontwikkelingen wordt aangetast, omdat mede daardoor er geen gemeenschap. pelijke normen en waarden meer zouden bestaan. Vanuit onder meer het wetenschapsonderzoek is kritiek op deze verenging in de discussie over maatschappelijke bindingen tot sociale normen en waarden. In zilin studie verzet Koenis zich tegen het idee dat waarden en normen van belang zijn om een samenleving bijeen te houden. Ten eerste zijn normen en waarden volgens hem minder betrouwbare bondgenoten bij het scheppen van maatschappelijke banden dan vaak wordt gedacht; normen en waarden sluiten sommige mensen birnen maar anderen juist buiten een gemeenschap. Ten tweede stuurt de wraag naar socia. le cohesie het debat in de verkeerde richting: "alsof er sprake is van één bindmiddel in plaats van een veelvoud van diverse bindmiddelen zoals de media, de markt, de populaire cultuur, de politiek, maar ook materiéle infrastructuur". ${ }^{75}$ Op basis van deze analyse herformuleert Koenis vervolgens het belang van politiek. Het belang van politiek is om in een samenleving waarin mensen niet kunnen terugvallen op gedeelde normen en waarden, ideeën te bedenken, voorzieningen te treffen en instituties te scheppen die het gebrek aan een gemeenschappelijke basis kunnen opvangen en reguleren. ${ }^{76}$

Hoewel Koenis' onderzoek gaat over de rol van de Nederlandse overheid in een multiculturele samenleving, kunnen zijn opvattingen over polittek ook worden gebruikt om de rol van de WHO te onderzoeken. De WHO heelt zich immers tot taak gesteld om met behulp wan wetenschappelijk onderzoek een gemeen. schappelijke basis te creëren woor de internationale bestrijding van ziekten. Hoe creëert de WHO een gemeenschappelijke basis en waar bestaat die uit?

Hoewel de figuratiesociologie en het wetenschapsonderzoek andere viragen stellen en andere terreinen onderzoeken, staat het concept netwerk centraal in de analyse. Dit concept is ook leidend geweest voor mijn analyses. ${ }^{77}$ De Swaan heeft het netwerk-concept geintroduceerd om de samenlevingsverbanden in kaart te brengen; in het netwerk worden onderlinge verbindingen met lijnen weergegeven en de mensen die met elkaar verbonden zijn met knooppunten. ${ }^{78}$ De definitie die Latour geeft wijkt daar weinig wan af. Latour definieert een netwerk als een verzameling van versterkingen (knooppunten) die met elkaar verbonden zijn (het net). ${ }^{79}$ Op het eerste gezicht lijkt het netwerk een relatief eenvoudig begrip. Bij een nadere beschouwing van de verschillende arralyses van 
de ontwikkeling van netwerken blijkt het netwerkcancept echter een veelzijdig begrip. Algemeen is het netwerkconcept ingezet om processen of instituties te ontleden. Om te voorkomen dat processer, organisaties of instituties als monolithische eenheden worden beschouwd, worden de afzonderlike actoren en hun relaties onderzocht. In de wijze waarop de opbouw van netwerken wordt beschreven, worden echter verschillende accenten gelegd. De Swaan will vooral weten hoe ver afhankelikheidsrelaties strekken en wie met wie verbonden is geraakt. Latour is geinteresseerd in de heterogeniteit van netwerken. In zijn onderzoek laat hil zien hoe wetenschappers heel verschillende zaken met elkaar weten te verbinden (maatschappelijke problemen, theorieën, instrumenten, organisaties, et cetera). Een centrale vraag in het werk van Latour is de vraag hoe in de opbouw van netwerken kennis, technieken en sociale verhoudingen transleren. In deze studie worden deze verschillende aspecten van het begrip netwerk naast elkaar, maar wel gescheiden van elkaar . ingezet. In hoofdlstuk twee ligt de nadruk op de heterogeniteit van bindingen, dat wil zeggen op de verschillende manieren waarop actoren binnen het netwerk aan elkaar verbonden zijn. In hoofdstuk drie wordt de opbouw van een keten wan heterogene elementen gevolgd. In dat hoofdstuk wordt ook de vraag beantwoord wat er gebeurt als een element uit de keten loslaat en de keten dus breekt. Hoofdstuk vier laat de complexiteit van bindingen zien, dat wil zeggen hoe mensen en dingen op onverwachte wijzen aan elkaar verbonden worden.

\section{.5 De casus}

Om de vraag te beantwoorden welk werk wordt verricht om te registreren, is de ontwikkeling van één bepaalde registratie als casus geselecteerd: het "WHO-netwerk voor de isolatie en karakterisering van HIV". Dit WHO-netwerk is een samenwerkingsverband tussen laboratoria uit verschillende landen, met diverse dis* ciplinaire achtergronden. Samen hebben zij tussen 1989 en 1993 een registratie opgezet om de diversiteit van HIV in kaart te brengen ten behoeve van de ontwikkeling van vaccins.

Dit WHO-netwerk is om meerdere pedenen een interessante casus. Het is ten eerste een woorbeeld van een transnationaal netwerk binnen een internationale organisatie. In dit WHO-netwerk werken laboratoria uit verschillende landen met elkaar samen zonder dat nationale overheden een directe rol spelen.

Een andere reden waarom het WHO-netwerk voor mijn onderzoek een interessante casus is, zijn de verschillende disciplinaire achtergronden van de laboratoria. Sommige laboratoria geven een genetische karakterisering van HIV, anderen een immunologische of een biologische karakterisering. De laboratoria zijn om verschillende redenen in de karakterisering van HIV geïnteresseerd en stellen derhalve andere vragen. Hun methoden van onderzoek verschillen en waarschijnlijk hanteren zij ook andere criteria voor goed onderzoek. Hoe slagen de laboratoria er in onderlinge verschillen te overbruggen en samen de diversiteit van HIV in kaart te brengen? Voor de ontwikkelling van beleid is discussie onder 
wetenschappers over wat er aan de hand is lastig Beleidsmakers moeten handelen en daarvoor is het juist van belang dat over de kennis die de basis van het beleid vormt, niet getwist wordt. De verschillen in opvatting over de karakterisering van HW maken het WHO-netwerk daarom tot een interessante casus om te onderzoeken hoe wetenschappelije kennis in beleldspraktijken wordt ingepast. Daar komt nog bij dat het uiteindelijke doel waarvoor de gegevens over de diversiteit van HIV verzameld worden, namelik het opzetten van de vaccinstudies, in wetenschappelijke nijdschriften ter discussie stat. Het WHO-netwerk is kortom een goed voorbeeld om te onderzoeken hoe de WHO omgat met verschillende opvattingen over kennis.

Bovendien werken in het WHO-netwerk laboratoria uit ontwikkelingslanden (de primaire laboratoria) samen met laboratoria in ontwikkelde landen (de secun. daire laboratoria). Voor de WHO is het overbruggen van de kloof tussen ontwikkelingslanden en ontwikkelde landen een belangrijke beleidsdoelstelling. Eén van de manieren waarop de WHO de verschillen tussen deze landen wil verkleinen is door de uitwisseling van technologie, maar dat levert allertei problemen op. Technologie die in westerse landen is ontwikkeld, blijkt vaak niet bruikbaar in ontwikkelingslanden omdat noodzakelijke voorzieningen ontbreken. In het globaliseringsdebat is erop gewezen dat in tegenstelling tot officiele hulpprogramma"s, de uitwisseling van muziek en keukens tussen ontwikkelde en antwikkelingslanden wel snel is gegaan. Het kan daarom interessant zijn om de uitwisseling van kennis en techniek vanuit een transnationaal perspectief te bekijken.

Voor de ontwikkeling van het WHO-netwerk wordt de "Technische Werkgroep voor de Isolatie en Karakterisering van HIV" (voortaan de Technische Werkgroep) opgericht. Deze werkgroep bestaat uit vertegenwoordigers van de dieelinemende laboratoria. In 1989 komt de werkgroep voor de eerste maal bijeen op het hoofd. kwartier van de WHO in Genève voor een "weedaagse bijeenkomst. Het doel van deze vergadering is om een plan te maken voor de opzet van de registratie en afspraken te maken over leders taken. Besloten word om woor de registratie het "WHO-netwerk voor de isolatie en karakterisering van HIV" op te fichten. Het WHO-netwerk zal volgens dit plan bestaan witt drie niveaus (zie figuur 1):

1. Primaire laboratoria die bloedmonsters verzamelen van mensen die met HIV geïnfecteerd zijn;

2. Een centraal depot waar alle bloedmonsters worden samengebracht en bewaard voor verder onderzoek;

3. Secundaire laboratoria die de bloedmonsters onderzoeken en HIV karakteriseren.

De gegevens over de donoren en de bloedmonsters zullen in een database worden opgeslagen. 
Figuur 1: Het WHO-netwerk voor de isolatie en karakterisering van HIV.

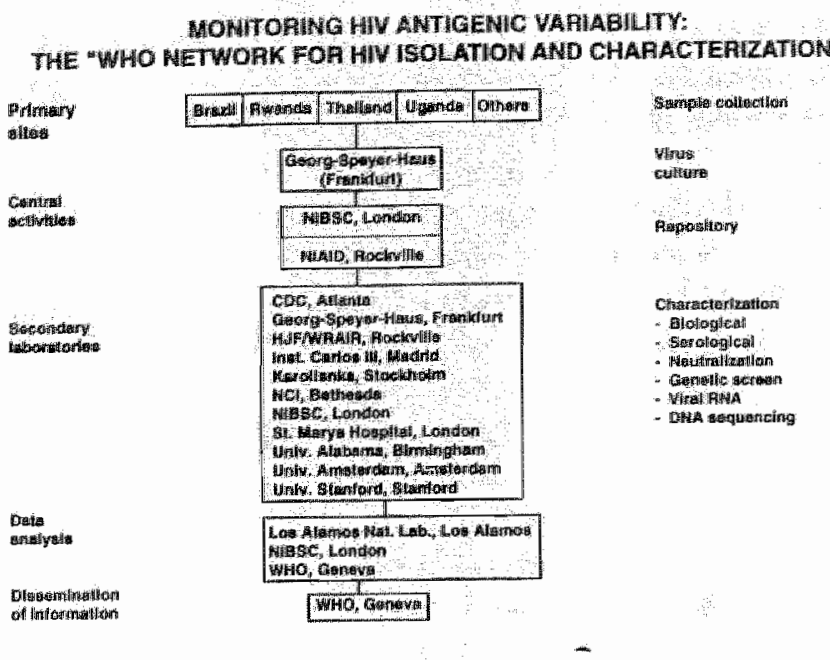

Gron: WHONHO network for HIV isolation and chaladerization (1992). Proposal for an international collaborative study on HIV isotation and characterization. WHO: Genèwe.

Als het plan voor de oprichting van het WHO-netwerk is voorgelegd en goedgekeurd door de stuurgroep van de WHO woor vaccinontwikkeling gaat in 1992 een pilotstudy van start. Het doel wan de pilotstudy is na te gaan of het plan in de praktijk gerealiseerd kan worden. De werkgroep weet dan nog niet of de bloedmonsters die door de primaire laboratoria worden verzameld bruikbaar zijn woor onderzoek in de secundaire laboratoria. De grootste zorg is dat de bloed. monsters die van de primaire laboratoria via het depot naar de secundaire laboratoria worden gestuurd, ergens onderweg beschadigd raken. Ook is men bang dat de bloedmonsters die door de primaire laboratoria worden verzameld niet aan de eisen van de secundaire laboratoria voldoen. In de pillotstudy worden op kleine scliaal alle stappen wan de registratie gezet: er worden bloedmonsters verzameld, de bloedmonsters worden naar het depot gestuurd, in het depot worden de bloedmonsters bewerkt en daarna gedistribueerd naar de secundaire laboratoria die hel bloed onderzoeken en ten slotte worden de resultaten van de karakterisering van HV ingevoerd in een database van het Los Alamos National Laboratory (LANL). De resultaten van de pilotstudy worden op een vergadering van de werkgroep in september 1993 besproken. Op de bijeenkomst van de technische werkgroep waar de resultaten van de pilot worden geëvalueerd, worden aanbevelingen gedaan voor de verdere ontwikkeling van de registratie. In deze studie wordt de ontwikkeling van de registratie gevolgd vanaf die eerste vergadering in december 1989 tot aan de afronding van de pilotstudy in 1993. 
Voor het onderzoek zijn de vergaderstukken van de technische werkgroep bestudeerd in de periode van december 1989 tot en met september 1993, dat wil zeg. gen de periode vanaf de eerste vergadering van de werkgroep tot en met de vergadering waarin de resultaten van de pilotstudy werden besproken (zie de bronnenlijst). In die periode zijn vier officiële vergaderingen georganiseerd. Daarnaast zijn nog enkele informele bijeenkomsten georganiseerd waarbij niet alle leden van de werkgroep aanwezig waren. Van elke vergadering werd een rapport gemaakt. De rapporten van de eerste drie vergaderingen ziln projectvoorstellen in verschillende versies. Het rapport wan de laatste vergadering beschrifft de eerste resultaten van de pilotstudy. Voor de vergaderingen ziln tal van vergaderstukken geschreven van vergaderagenda's, plamen van de afzonderlike laboratoria voor het verzamelen van bloedmonsters of de karakterise: ring daarvan, tot een officiële WHO-richtlijn voor de isolatie en karakterisering van HIV.

De belangrijkste bromen voor deze studie zijh dus niet de officiële rapporten van de WHO, maar de conceptversies van deze rapporten en de vergaderstukken op basis waarvan de rapporten zijn geschreven. Het schrijven en bespreken van deze vergaderstukken maakt een belangrijk deel uit van het werk van de technische werkgroep. De vergaderstukken kunnen in een bepaald opzicht vergeleken worden met de labjournaals die wetenschapsonderzoekers hebben geanalyseerd in hun studies van laboratoria. In de vergaderstukken wordt beschreven wat de technische werkgroep heeft gedaan om het WHO-netwerk op te bouwen. In het voorstel voor de opzet van het WHO-netwerk wordt bijwoorbeeld beschreven over welke voorzieningen de primaire laboratoria moeten beschikken om bloedmonsters te verzamelen. Tegelijkertijd wordt in de vergaderstukken, net als in de labjournaals, verantwoording afgelegd van wat men heeft gedaan. De versichillende versies van bijvoorbeeld het projectvoorstel geven de mogelijkheid te onderzoeken hoe de opzet wan het WHO-netwerk wordt onderbouwd en steeds verder wordt dichtgespijkend. Anders gezegd, in de documenten zijn sporen te vinden van de formele en de informele kant van de ontwikkeling van de registratie. 0 p basis warl de documenten kan een recon. structie worden gemaakt van wat de technische werkgroep wilde doen (de formele doelstellingen) en wat de technische werkgroep heeft gedaan (informeel). De vergaderstukken zün verkregen wia een lid van de werkgroep waarmee ook gesprekken zijn gevoerd over het WHO-netwerk.

De vergaderstukken van de werkgroep kumnen ook beschouwd worden als verdichtingen in het netwerk. Zoals in paragrataf drie reeds is opgemerkt, beschouwt De Swaan internationale organisaties als een goede plek om de ontwikkeling van een transnationalal netwerk te kunnen onderzoeken. Over hoe die relaties kunnen worden onderzocht, aan de hand van welk bronnenmateriaal, spreekt De Swaan zich niet uit. In mijn studie heb ik gekozen voor de vergaderstukken. In de wergaderstukken worden de problemen op de verschillende niveaus besproken: lokaal (wat gebeurt er in de afzonderlijke laboratoria?), interlokaal (hoe kunmen monsters en gegevens worden overgedragen?), nationaal (zullen nationale overheden toestemming geven voor vaccinstudies of voor de publicaties van 
gegevens over aids?) en internationad (hoe kan de samenwerking in wetenschappelijke onderzoek tussen landen worden verbeterd?). De vergaderstukken kumnen inzicht geven op de heterogeniteit van de transnationale bindingen. In de vergaderstukken worden niet alleen de ondertinge afspraken tussen de betrokken onderzoekers, laboratoria en landen vastgelegd, maar wordt ook de materiêle infrastructuur beschreven die nodig is om de laboratoria aan elkaar te verbinden zodat de uitwisseling van monsters en gegevens mogelijk wordt.

Nief alles wat in de technische werkgroep is besproken of wat de leden van de technische werkgroep hebben gedaan om de registratie op te zetten is op papier gezet. De keuze van de brominen laat een deel vam de ontwikkelingen onderbelicht. Een deel wan de kritiek die op de registratie is geweest, is waarschijnlijk niet gehoord. In de documenten is een brief van critici die het nut van de registratie ter discussie stelt. ${ }^{810}$ Volgens hen zal de registratie de ontwikkeling van het vaccin nilet verder helpen. Over de problemen bij de ontwikkeling van een $H \mathrm{~V}$ vaccin wordt werder nauwelijks geschreven (zie hoofdstuk 2). De documenten zijn dus tegelijkertijd ook beperkt materiaal. De beperkingen van het materiaal hebben in de analyse ervan een belangrijke plaats ingenomen door scherp onderscheid te maken waarover wel en geen uitspraken kunnen worden gedaan. Om de ontwikkeling van de registratie te beschrijuen met alle factoren die daarbij mogelijk een rol hebben gespeeld, is het bronnenmateriaal dat in deze studie is onderzocht te beperkt. Dat is ook niet de inzet van deze studie. In deze studie wil ik nagaan of en vooral hoe allerlei organisatorisch werk invloed heeft op de ontwikkeling van kennis en beleid. Wat betekent het voor het werk van de WHO wanneer zij wetenschap inzet en andersom wat betekent het voor wetenschappelijke onderzoek wanneer het de beleidscontext van de WHO wordt binnengehaald? Zulk organisatorisch werk wordt meestal over het hoofd gezien. In de meeste studies naar de ontwikkeling van beleid worden alleen officiële rapporten gebruikt. Deze studie wijkt daarvan af in die zin dat ook de tussentijdse versies van rapporten en losse vergaderstukken zijn bestudeerd, waarmee meer inzicht kan worden verkregen in beleid-in-wording in plaats van in kanten:klaar beleid.

Om de ontwikkeling van wetenschappelijke kennis te kunnen analyseren is het van belang om voldoende te weten over de inhoud van die kennis. In studies van het wetenschapsonderzoek worden daarom technische details over experimenten niet gemeden. Voor deze studie heb ik mij oak verdiept in het onderzoek naar HIV, zij het beperkt. Naast de vergaderstukken van het WHO-netwerk is op basis van een literatuurstudie van artikelen in wetenschappelijke tijdschriften de discussie over de HIV-vaccins in kaart gebracht. Het betreft een aantal overzichtsartikelen over de ontwikkeling van HIV-vaccins uit algemene wetenschappelijke tijdschriften zoals Science en Nature en meer specifieke wetenschappelijke tijdschriften zoals Vaccine. Daarnaast is in Science tussen 1990 en 1996 een serie artikelen verschenen over de besluitvorming rondom het opzetten van grootschalige vaccinstudies in de Verenigde Staten. In Nature zijn naar aanleiding van de beslissing wan de WHO om vaccinstudies in ontwikkelings. 
landen op te gaan zetten (terwijl diezelfde vaccinstudies in de Verengde staten werden uitgesteld) een aantal artikelen verschenen over dit besluit van de WHO. Het doel van deze literatuurstudie was niet zo zeer on precies op de hoogte te raken wan de opzet van de experimenten, mar om de context van het WHOnetwerk te beschrijven. Naast literatuur over de ontwikkeling van HW-vaccins, is ook literatuur verzameld over de databases die in de moleculaire biologie ziln ontwikkeld en over de belangrikste onderzoeksvragen wan de betrokken disci. plines. Daarvoor is geen analyse gedaan van primair bronnenmatteriaal, maat is voornamelijk gebruik gemaakt van eerder gedane analyses naar de betrokken disciplines vanuit het perspectief wan het wetenschapsonderzoek.82

\section{.6 De opzet van de studie}

In deze studie wordt beschreven welk werk er wordt verricht on een registratie op te zetten en de effecten daarvan op de kennis over de diversiteit van HIV binnen de beleidscontext van de WHO, het beleid van de WHO voor de ontwik. keling van vaccins en de wijze waarop laboratoria maar ook de vrijwilligers die bloed geven woor het onderzoek met de WHO verbonden raken. Anders geformuleerd, ik beschrijf in deze studie de ontwikkeling van een transnationaal wetenschappelijk netwerk. In elk hoofdstuk wordt dat netwertk op een andere manier doorkruist.

Het WHO-netwerk wordt zoals gezegd opgezet te midden van een discussie over de effecten van de genetische diversiteit van HIV voor de ontwikkeling van een effectief HIV-vaccin. In hoofdstuk twee staat de vraag centraal hoe de WHO met discussies over de wetenschappelijke basis van haar beleid omgaat. Het hoofdstuk gaat over de ontwikkeling van het plan voor het WHO-netwerk en de voorbereidingen die worden getroffen om het plan te realiseren. De technische werkgroep komt in die tijd verschillende keren bij elkaar voor vergaderingen en schrifft een projectvoorstel voor de stuurgroep voar vaccinontwikkeling. Zulk werk - vergaderen, stukken schrijver en herschrijven - is typisch voor het werk van een bureaucratische organisatie als de WHO. Voor dat werk is meestal weinig aan. dacht, behalve dat gezegd wordt dat het te veel tijd kost en te weinig oplevert. In dit hoofdstuk wordt dit organisatorische werk in detall beschreven om de effecten daarvan na te gaan op de inhoudelijke ontwikkeling van de registratie, in het bijzonder op de verhouding wan de verschillende standpunten over de betekenis van de genetische diversiteit van HIV voor de ontwikkeling van het vaccin binnen het WHO-netwerk.

In hoofdstuk drie staat het werk centraal dat wordt verricht om te regiistreren en de effecten daarvan op het beleid van de WHO. Met het oog op toekomstige vaccinstudies, wordt niet alleen de genetische diversiteit van HIV (verschillen in het genetisch materiaal) in kaart gebracht maar ook de antigene diversiteit (verschillen in de structuur van de eiwitmantel). Voor de registratie van de genetische diversiteit van HIV zijn reeds classificaties en databases ontwikkeld en daarvan wordt voor de WHO-registratie ook gebruik genaakt. Voor de WHO is de 
keuze om gebruth te maken van de infrastructuut die reeds is opgebouwd voor de registratie van de genetisch diversiteit van HIV een praktische c.q. organisatorische keuze. De WHO hoeft dan zelf geen infrastructuur op te bouwen woor de gegevens. Wat is het effect van deze praktische keuze voor de inhoudelijke ontwikkeling van de registratie? Hoe en in hoevere drukt de infrastructur voor de registratie van genotypen een stempel op de ontwikkeling van de WHO-registratle die als doel heeft om behalve de genetische ook de antigene diversiteit wan HV in kart te brengen? Wat betekent een mogelike verschuiving in de verhouding tussen de genetische en antigene diversiteit voor het uiteindelike beleldsdoel van de registratie: de planning van vaccinstudies?

in hoofostuk vier staan de beleidsdoelstellingen van het WHO-netwerk centraal. Het doel vain het WHO-netwerk is om de antwikkeling van vaccins te bevorderen. In ontwikkelingslanden, waar aids zich het snelst verspreidt, ziln vaccins het enige betaabare altermatief bij de bestrijding van aids. Ontwikkelingslanden beschikken echter niet over de kennis en de magelijkheden om vaccins te ontwikkelen, die rijke landen wel hebben. Om die reden zijn de landen waar als eerste door de WHO de diversiteit in kaart wordt gebracht, vier ontwikkellings. landen. De gegevens over de diversiteit van HIV kunnen worden gebruikt in de voorbereidingen voor de vaccinstudies. Daarnaast biedt de samenwerking met laboratoria in Europa en de Verenigde Staten de mogelijkheid voor de labora. toria in ontwikkelingslanden om meer kennis te verkrijgen voor hum eigen onderzoek. Met het oog daarop hebben de secundaire laboratoria afgesproken om uitwisselingsprogramma's op te zetten en speciale technieken te ontwikkelen waarmee de primaire laboratoria zelf de virussen kumnen karakteriseren. De overdracht van techniek brengt meestal veel problemen met zich mee. Tegelijkertijd zijn er ook aanwijzingen dat binnen transnationale netwerken ideeẻn en goederen snel worden uitgewisseld, zoals de ontwikkeling van de internationale keuken en wereldmuziek laat zien. Een interessante vraag is daarom hoe in het WHO-netwerk de verhoudingen tussen enerzijds de primaire en de secundaire laboratoria en anderzijds tussen de vrijwilligers in ontwikkelingslanden en de WHO worden gevormd.

In het slothoofdstuk wordt op basis van de inzichten uit deze stucle het beeld zoals dat van de WHO bestaat herzien. In deze studie wordt het werk van de WO beschreven om te registreren en worden de effecten van dat werk onderzocht op de ontwikkeling van kemnis, beleid en verhoudingen tussen de WHO. de laboratoria en de vijwilligers. Daarbij wordt teruggegrepen op het debat over de WHO waamee dit hoofdstuk is begonnen. De WHO wil vasthouden aan de technische alanpak van gezondheidsproblemen. Critici winden zo'n benadering te smal omdat daarmee belangrijke problemen blijwen liggen. In het slothoofdstuk zal ik betogen dat de veronderstelling over de scheiding tussen technische en politieke zaken waarwan zowel de WHO als haar critici uitgaan, een oplossing van de crisis in de weg staat. Daal zal ik pleiten voor een transinationale gezondheidsorganisatie die kennispolitiek bedrijt. 
$\frac{2}{40}$ 


\section{hoofdstuk 2:}

\section{Bij gebrek aan consensus}

\section{Over verschillen en eenheid in het WHO-netwerk}

\section{.1 Introductie}

Om niet door politieke conflicten te worden verlamd, heeft de WHO - zoals in hoofdstuk 1 is beschreven - gekozen voor een wetenschappelijke en technische aanpak van gezondheidsproblemen. De inzet van deskundigen, aldus de WHO, is nodig om over de aanpak van gezondheidsproblemen consensus te kunnen bereiken. Deze professionele consensus is voor de WHO de basis wan haar beleid. Wetenschappers blijken het echter lang niet altijd met elkaar eens te zijn. Sterker nog, controverse-studies maken duidelijk dat wetenschappers het in bepaalde gevallen nooit eens zijn geworden, ondanks jarenlang onderzoek en uitwoerige discussies (zie hoofdstuk 1). De verschillen in opvatting over de aanpak van het onderzoek, de relevante (theoretische) uitgangspunten en de resultaten van het onderzoek blijwen in controverses lang bestaan en worden naar mate contro* verses zich verder ontwikkelen lang niet altijd kleiner. Zulke verschillen en meer algemeen hel voortdurend in twijfel trekken van wetenschappelijke feiten, wordt ook juist gezien als de motor achter de ontwikkeling van wetenschappelikk ken* nis. Onzekerheid over de bestaande kennis kan immers een reden zijn om verder onderzoek te doen. ${ }^{83}$

Voor de WHO die op basis van wetenschappelijke kennis beleid wil ontwikkelen, kunnen discussies over de juistheid van de bestaande kenn's een probleem vormen. Als de WHO meerdere deskundigen raadpleegt, krijgt zij verschiliende. al dan niet tegenstrijdige - adviezen over de juiste aanpak van een beleidsprobleem. De WHO kan echter niet blijven wikken en wegen, zij wordt gedacht te handelen. ${ }^{84}$

De WHO wil samen met laboratoria gegevens verzamelen over de genetische en de antigene diversiteit van HIV om die gegevens vervolgens te gebruiken voor de ontwikkeling van HIV-vaccins. Er is, als in 1989 het WHO-netwerk wordt opgericht, nog geen effectief HIV-vaccin voor handen. Dat is zo kort na de ontdekking vam het virus niet zo verwonderlik. Het is echter de waag of zo"n vaccin wel ontwikkeld kan worden. HIV blijkt een grote genetische diversiteit te heb- 
ben. De genefische diversiteit is mogelijk een obstakel voor de ontwikkeling van vaccins. Een waccin zou alleen voor specifeke varianten werkzaam kunnen zijn. Bovendien veranderen die varianten voortdurend, waardoor ook de daarop toegesneden vaccins snel hun effectiviteit zouden kunnen verliezen. Of de genetische diversteit leidt tot uiterlijke werschillen van het wirus en of die uiterlijke verschillen van belang zijn voor de immuunreactie en datamee woor de werking van het vatcin is onduidelijk. Het is dus niet zeker dat de genetische diversiteit een probleem is woor de ontwikkeling van HIV-vaccins. Het WHO-netwerk dat tot doel heeft de genetische en de antigene diversiteit wan HIV in kaart te brengen ten behoeve wan de ontwikkeling van vaccins, wordt kortom opgericht te mid. den van een discussie over de diversiteit wan HIV in relatie tot de ontwikkeling van vaccins.

De laboratoria in het WHO-netwerk hebben verschillende disciplinaire achtergronden en zij brengen de diversiteit op verschillende manieren in kaart. Hoe kunnen de laboratoria in het WHO-netwerk samenwerken zonder dat zij in conflict komen over de juiste wijze om de diversiteit van HIV in kaart te brengen? Een mogelike voorwaarde om samen te werken is, zoals gezegd, professionele consensus. De wraag die in dit hoofdstuk centraal staat is of in het WHO-netwerk naar consensus wordt gestreefd over de wijze waarop de diversiteit van HIV in kaart dient te worden gebracht. Zo ja, hoe wordt consensus bereikt? En zo nee, hoe is het voor de WHO (en de laboratoria) dan mogelijk om zonder consensus over de wetenschappelijke feiten verder te gaan? Heeft de WHO, zoals Koenis dat formuleert (zie hoofdstuk 1), voorzieningen getroffen om het gebrek aan een gemeenschappelijk basis op te vangen. 85 Met andere woorden, slaagt de WHO er in om de laboratoria op andere manieren aan elkaar te binden dan via gedeelde opvattingen?

Het hoofdstuk is als volgt opgebouwd. In paragraaf twee wordt beschreven hoe de ontwikkeling van HIV-vaccins is gegaan en welke problemen zich claarbij hebben voorgedaan. In de beschrijing die ik geef, besteed ik niet alleen aandacht aan de verschillende opvattingen over de mogelijkheden om een effectief HIVvaccin te ontwikkelen, maar ga ik ook in op de verschillende manieren van onderzoek van de betrokken disciplines. De beschrijving richt zich op het werk dat is verricht om kennis te ontwikkelen, zoals de wijze watrop gegevens worden verzameld en het soort onderzoek dat is gedaan. Om na te gaan of en hoe tot consensus wordt gekomen wordt in paragraaf drie nagegaan hoe over de geneti. sche en de antigene diversiteit in de documenten van de technische werkgroep wordt geschreven. In de laatste paragraaf wordt ingegaan op de vraag hoe de WHO een mogeliik gebrek aan consensus opvangt. Die paragraaf beschrijft het organisatorisch werk dat de technische werkgroep heeft verricht om het WHOnetwerk op te zetten. De organisatie van vergaderingen, het schrijven van rapporten en de opzet van een materiêle infrastructuur worden in deze paragraaf beschouwd als stappen in de opbouw van een heterogeen netwerk waarin de actoren op vele manieren met elkaar verbonden worden. 


\section{.2 Een controverse over de effectiviteit van HIV-vaccins}

Wanneer de WHO halvewege de jaren lachtig de verspreiding van infectiezlekten onder controle lijkt te hebben en har aandacht gaat verplaatsen naar andere gezondheidsprobiemen, zoals chronische ziekten, wort zil geconfronteerd met een geheel nieuwe zlekte: aids.

\section{Gegevens over het onbekende}

De ontdekking van aids als een afzonderlike ziekte is mede een onverwacht effect van registratiepraktijken. ${ }^{86}$ in de Verenigde Staten wordt door de Centers for Disease Control (CDC) een registratie bijgehouden over het gebruik van schaars beschikbare geneesmiddelen. Artsen die bepaalde geneesmiddelen willen voorschrijven, zijn verplicht dat te melden bij het CDC. Op die manier wordt enerzijds het gebruik van dergelijke (nog) schaarse geneesmiddelen gereguleerd en wordt anderzijds informatie verzameld over de patienten die met die middelen worden behandeld. Ten slotte levert deze registratie zicht op de resultaten van behandeling. Pentamidine is zo"n geneesmiddel. Het is bestemd voor patienten met een bijzonder soort longontsteking, pneumocystis carinii. Die vorm van longontsteking komt alleen voor bij mensen van wie het immuunsysteem emstig is verzwakt, bijwoorbeeld als nasleep van zware chemotherapie.

Op 1 februari $1981 \mathrm{krijgt} \mathrm{het} \mathrm{CDC} \mathrm{voor} \mathrm{de} \mathrm{tweede} \mathrm{maal} \mathrm{binnen} \mathrm{korte} \mathrm{tijd} \mathrm{van} \mathrm{een}$ arts uit New York een werzoek Pentamidine te verstrekken. De CDC-medewerker die de aamwagen van Pentamidine afhandelt, is verbaasd omdat het medicijn zelden wordt voorgeschreven en er nog nooit éên arts is geweest die in het tijdsbestek van een maand voor twee patiënten het middel heeft aangevraagd. Bovendien kan de arts de aorzaak van deze zeldzame longontsteking niet verklaren, zoals de registratie voorschrijft. De patiënten waar thet om gaat hebben namelijk geen chemotherapie gehad. Volgens de arts die het geneesmiddel heeft aangevraagd, zijn er ook geen andere mogelijke factoren die voor een ineenstorting van het immunsysteem veranwoordelijk zouden kunnen zijn. In de weken daarna krijgt het CDC maar liesst negen nieuwe aanviagen voor Pentamidine, allemaal van artsen uit New York. Negen aanwragen uit één stad in $20^{\prime \prime}$ karte tijd is een zeer hoog aantal gezien het gemiddelde ván 80 mel dingen die het CDC tol dan toe jaarlijks uit de gehele Verenigde Staten heeft gekregen. Vanwege dit opvallend hoge aantal aanvragen en het feit dat de aan. vragen niet valledig zijn ingevuld, omdat de arts de oorzaak van het disfunctioneren van het immuunsysteem niet weet, besluit het CDC de federale overheid te walarschuwen en wordt een epidemiologisch onderzoek gestart. ${ }^{87}$ De epidemiologie beschikt over onderzoeksmethoden die kunnen worden gebruikt zonder dat verder iets bekend is over een ziekte. Het gaat dan om registraties, casebeschrijuingen en cohortstudies. Dankzij die methoden kan de epidemiologie richting geven aan verder medisch onderzoek en de formulering van mogeliik oplossingstrategieén. De gegevens die de epidemiologie over de nieuwe ziekte verzamelt leiden er al snel toe dat vooruitgang wordt geboekt in het onderzoek; er kunnen hypothesen worden geformuleerd en resultaten wor- 
den gepresenteerd. Begin jaren lachtig, wanneer de eerste gewallen van deze ziekte bekend worden, is nog onbekend dat het om een infectieziekte gaat. Deze geheimzinnige ziekte, die het afweersysteem aantast waardoor tal van (vaak exo. tische) infecties een kans krijgen, word als eerste bij homoseksuele mannen in de Verenigde Staten geconstateerd. Ondat de later zogenoemde aids-patiènten" allemaal homoseksuele mannen ziln, wordt de oorzak van de ziekte in eerste instantie gezocht in hun gedrag. 'Slijtage' van het afweersysteem door een lange rij van geslachtsziekten of het gebruik van "poppers' - een drug die seksuele beleving versterkt - worden in die eerste periode als mogelijke oorzaken genoiemd 89 Als in 1983 de dan nog onbekende ziekte voor het eerst wordt geconstateerd bij immigranten uit Haiti en ook bij mensen die een bloedtransfusie hebben gekregen, ontstat het vermoeden dat de ziekte wordt overgedragen door bloed en mogelijk wordt veroorzaakt door een virus.90

\section{Een vaccin, a magilic bullet?}

Na de isolatte van HIV in 1987 en de antwikkeling van betrouwbare serologische methoden om antilichamen aan te tonen, wordt aids wooral een probleem vam de biomedische wetenschappen. De laboratoriumwetenschappers hebben namelijk een bellangrijke troef in handen: de mogelijkheid om een waccin te ontwikkelen. Zoals lohn Moore formuleert:

"Vaccines are the major success story of biomedical research the therentieth century, given the global eradication of smallpox and the successul control, at least in some parts of the world, of nine major infections - tuberalosis, diphtheria, tetanus, yellow fever, pertusis, polio, measles, mumps and nubella".,"1

Wereldwijde vaccinatieprogramma's zijn voor de WHO een beproefd en eerder zeer succesvol gebleken beleid tegen infectieziekten. Al snel blijkt echter dat aids niet met zulke traditionele middelen te overwinnen is. Het Human Immunodeficiency Virus of HIV dat de ziekte veroorzaakt is anders en laat zich niet met gangbare maatregelen bestrijden. Terwijl de pokken door haar langzame verspreiding en eenvoudige vacinatie bijna een ideale ziekte is woor de WHO, is aids een wetenschappelijke en klinische nachtmerie (zie hoof'dstuk 1). HIV stelt de experimentele biomedische wetenschappen voor geheel nieuwe problemen. ${ }^{2}$ Onder normale omstandigheden bestaat de beschermende werking van een vaccin erin dat het de natuurlike afweerreactie van het lichaam ver. sterkt. De productie van specifieke antilichamen tegen een virus of bacterie wordt versneld en versterkt. Kan een vaccin echter zijn werk doen wanneer de afweerreactie zelf door het virus wordt verstoord? In het immuunsysteem spelen de zogenaande T-cellen een centrale rol. Het HIV dringt nu precies de T-cellen binnen en belemmert het normale functioneren, waardoor het immuunsysteem in zijn geheel ontregeld raakt.

HIV heeft daamaast nog een andere eigenschap waardoor programma's om een vaccin te ontwikkelen bij woorbaat gedoemd lijken te mislukken. Het virus, zo blijkt aan het eind van de jaren tachtig, vertoont een nog zelden waargenomen 
genetische diversiteit. Er worden steeds nieuwe varianten van het virus ontdekt; het virus lijkt de mogelikkeid te hebben zich steeds opnieuw vorm te geven. De vraag is dan of de antilichamen die een vaccin genereert ooit specifiek genoeg kunnen zijn om de uiteenlopende en misschien almaar veranderende vormen van het virus te bevechten. Desondanks slagen farmaceutische bedrijen er eind jaren tachtig in om enkele HIV-vaccins te ontwikkelen.

De effectiviteit van die vaccins wordt echter door cleskundigen betwist. Er ontstaat onder hern een controverse over de effectiviteit van de HIV-vaccins. Tal van ingewikkelde kwesties staan daarbij ter discussie: de consequenties van de genetische diversiteit voor de antigene kenmerken van HIV, de verhouding tussen laboratoriumonderzaek en experimenten met mensem en de besluitvorming bin. nen grote gezondheidsorganisaties als de WHO en de uit de Verenigde Staten afkomstig National linstitutes of Health (NIH).

\section{De genetische en de antigene diversiteit}

Waarom is de genetische diversiteit een belangrijke kwestie voor de ontwikkeling van een vaccin? De reden is dat verschillen in de volgorde van nucleotiden in het RNA gevolgen kan hebben voor de antigene kenmerken van HIV.93 Een antigeen is dat deel van de virusmantel (de buitenkant van het virus) waaraan het immuunsysteem het virus als een lichaamsvreemde binnendringer in thet lichaam herkent. De antilichamen die het immuunsysteem vervolgens produceert passen ruwweg op het antigeen, zoals een sleutel in een slot. De effectiviteit van de immuunreactie is afhankelijk van de specificiteit van het antilichaam voor het antigeen. Hoe preciezer dit "past" des te effectiever de reactie. ${ }^{94}$ Parallel aan de manier waarop over de verschillen in de opbouw van het RNA van HIV (de binnenste kern van het virus) wordt gesproken met de term genetische diversiteit, worden mogelijke verschillen in de antigene kenmerken van HIV (de bujtenkant) getypeerd als de antigene diversiteit van HIV.

Hoe verhoudt de genetische diversiteit van HIV zich tot de antigene diversiteit? HIV bestaat uit een RNA streng omringd door een eiwitmantel. Het RNA is werantwoordelijk voor de overdracht van erfelijke eigenschappen en bestaat uit vier verschillende basen: Uracill, Ademine, Guanine en Cytonine. Deze basen zili als het ware het alfabet van het erfelijk materiaal. De volgorde wan de basen in het RNA levert de genetische informatie. 95 Een lange keten basen vormt een soort tekst met instructies, waarmee nieuwe virussen kunnen worden aangemaakt. De volgorde van de basen is de genetische code die aangeeft welke eiwitten het virus kan synthetiseren. Dit is niet helemaal juist gezegd omdat een virus zelf geen eiwitten kan synthetiseren. Een virus is geen compleet organisme en heeft de stofwisseling van een cel nodig om te overleven. Omdat een virus geen organisme is, wordt niet gezegd dat een wirus leeft of zich voortplant: cen virus repliceert. $90^{\circ}$

In de volgorde van de vier basesoorten in het RNA zijn dus de erfelijke eigen. schappen vastgelegd. De genetische boodschap die in een streng RNA is vastgelegd kan veranderen, of zoals het heet muteren. Dat gebeurt bijwoorbeeld wanneer tijdens het kopiëren van het RNA foutjes worden gemaakt waardoor de 
volgorde van de basen verandert. 77 Die veranderingen in de genetusche boodschap kunnen echter grote consequenties hebben voor de verschijhïngsvorm van het virus. Herbij is wan belang dat ze de antigenen op de eiwitmantel kunnen veranderen. Antilichamen zouden dan niet "passen". Tegen een wirus dat zeer vaak veranderingen vertoont in de volgorde van het genetisch materiaal en dus steeds andere antigenen zou kumen produceren is geen vaccin opgewassen. $\$ 8$ Een via een vaccin opgeroepen immunreactie is binnen de kortste keren achterhald door veranderingen in de antigenen.

Niet elke verandering in de volgorde van het genetisch materiaal heeft dergelijke vergaande consequenties. Het kan bij weranderingen in de volgorde wan het RNA ook gaan om wijzigingen die geen of een triviale betekenis hebben voor het virus. Een flink deel van het RNA blijtt voor zover nu bekend ongebruikt, dat wil zeggen die delen bevatten geen genetische informatie. Van het poliovirus is bijwoorbeeld bekend dat de genetische diversiteit groot is, maar de verschillen in de volgorde van de nucleotiden hebben hier geen consequenties voor de antigene kenmerken wan het virus. ${ }^{99}$ De vraag is dan of dat ook bij HiV het geval is. Of hebben de onderzoekers hier met een genetische diversiteit te maken die de werking van een vaccin zal verstoren? Eën van de belangrijke vragen aan het onderzoeksfront van de wroege jaren 90 is daarmee gesteld: Hoe groot is de genetische en antigene diversiteit van HIV en hoe belangrijk is deze voor de ontwikkeling van een effectief vaccin? Heeft de genetische diversiteit van HIV, net als het poliovirus, geen relevante antigene diversiteit tot gevolg, of zorgt de genetische diversiteit hier juist wel voor grote problemen bil vaccinontwilkkeling? 100

De discussie hierover is vooral ook een discussie over prioriteiten in het onderzoek. In een ideale situatie wordt zowel de genetische als de antigene diversiteit van HIV geheel in kaart gebracht. Praktisch is dat echter onmogelijk. Het kost te veel tijd en geld om de volgorde van de basen in het RNA van HIV volledig te analyseren. Dat geldt eens te meer wamneer het onderzoek naar verschillen in genetisth materiaal in het kader van de voorbereiding van vaccinstudies op wereldwijde schaal moet plaatsvinden. Er moeten daarom keuzen worden gemaakt: Welk deel van het genetische materiaal wordt onderzocht? Welke delen van de elwitmantel worden geanalyseerd? Waar moet de meeste aandacht naar uitgaan, naar de genetische of de antigene diversiteit van HIV?

\section{Wat is een bewijs voor de effectiviteit van vaccins?}

De effectiviteit van vaccins wordt normaal uitgeprobeerd in clinical trials. Een climical trial bestaat wit drie fasen. ${ }^{\text {lol }}$ Eerst wordt het vaccin in het laboratorium getest. Daar kan onderzocht worden of het bloed na toevoeging van het serum antilichamen bevat en of die antilichamen een reactie aangaan met de ziekteverwekker. In de tweede fase wardt de effectiviteit van het vaccin getest op dieren. De dieren wordem eerst gevaccineerd en daarna geinfecteerd. Als de dieren gezond blijven, dan is het vaccin effectief. Mensen vaccineren is fase drie. Twee groepen vrijwilligers worden een bepaalde tijd gevolgd; de ene groep patiënten is wel gevaccineerd en de andere groep niet. Na een afgesproken periode wordt 
het aantal ziekte- en sterftegevallen geteld. Het werschil in thet aantal mensen dat ziek wordt of sterf geldt algemeen als de maat voor de effectiviteit van een vaccin.

In plaats van verschillende fasen kumen de drie onderdelen van de clinical trial ook worden beschouwd als drie verschillende maten woor de effectiviteit van het vaccin: 1) de vorming van antilichamen; 2) het uitblijuen van ziekte na besmetting van een dier; 3) verschuivingen in de incidentie van ziekte en sterfte op populatieniveau. De verschillende maten om de effectiviteit van het vaccin te meten botsen zelden met elkaar. Ten eerste wordt een logisch verband verondersteld tussen de vorming van antilichamen, gezonde proefdieren en lagere incidentiecijfers. Ten tweede wordt de effectiviteit van het vaccin niet tegelikertijd in het laboratorium, op dieren en op mensen getest. Het vaccin wordt eerst in het laboratorium getest en pas ais het vaccin die test heeft doorstaan, wordt het vaccin op dieren getest; hetzelfde geldt vor de stap wan dielproeven naar effectstudies bij mensem.

Bij het testen van de effectiviteit wan thet HIW-vaccin leveren de verschillende maten voor de effectiviteit van het vaccin echter wel problemen op. vanwege de discussie over genetische diversiteit en het feit dat HIV het immuunsysteem aäntast, wordt getwijfeld aan de betekenis van antilichamen in het bloed. Zijn de antilichamen een voldoende bewijs voor de effectiviteit van het vaccin? Kunnen de antilichamen die het vaccin opwekt, het virus neutraliseren? of is er meer nodig voor een effectieve afweerreactie? ${ }^{02}$ Daamaast wordt de vaste volgorde van de fasen in de clinical trial doorbroken ondat, zoals gezegd, dierproeven antbreken. De resultaten van de laboratoriumexperimenten kunnen niet gevolgd worden door dierexperimenten omdat goede diermodellen ontbreken. Muizen kunnen niet besmet worden met HIV. Chimpansees wel, maar die worden niet ziek. Er is daarom een alternatieve test ontwikkeld: het tellen van de T-cellen in het bloed. 103 Als het aantal T-cellen gelijk blijfi:, is dat een bewijs dat het vaccin het virus onschadelijk heeft gemaakt. De concentratie T-cellen wordt echter niet algemeen geaccepteerd als een marker, een spoor van immuniteit. Twiffels over de resultaten van de laboratoriumexperimenten en de beperkingen van dierexperimenten, maken de afweging of het vacin al dan niet op mensen kan worden getest, zeer moeilijk. Harde criteria om zon besluit te nemen, ontbreken. Moore schrijft hierover in 1994:

"Herein lies the crux of the debate: the likethood of" the products being efficacious to any extent. Unfortunately, nobdy knows zeith any centainty, and it all boils down to opinion. Nobody not even the most passionate advacate of the trial, that efficacy would approach $700 \%$, and few were prepared to guess at even $50 \%$. A significant majortity fet that efficacy would be close to $0 \%$.". 104

Het debat over de effectiviteit van het vaccin spitst zich dan toe op de vraag wat de volgende stap in het onderzoek is: meer laboratoriumonderzoek naar de werking wan het immuunsysteem, of doorgaan met de derde fase van een clini* cal trial en de effectiviteit van het vaccin testen op mensen. 105 Onderzoekers die de genetische diversiteit als een groot probleem zien voor de effectiviteit wan 
een vaccin; winden dat eerst meer fundamenteel onderzoek moet worden gedaan naar de werking van het immuunsysteem. Andere onderzoekers vinden daarentegen dat genoeg onderzoeken zijn gedaan die de veiligheid en de effectiviteit wan de reeds ontwikkelde vaccins bewijzen en dat het tijd wordt om de vaccins te testen op mensen. ${ }^{106}$

De stap van laboratoriumstudies en dierproeven naar experimenten is altijd lastig. Het is een besluit dat zorgvuldig moet worden genomen. Internationaal zijn criteria opgesteld wanneer het verantwoord is de derde fase van clinical trials aan te vatten. Vanwege de hoge kosten van dergelijk onderzoek zijn de WHO of andere grote gezondheidsorganisaties als het National Institutes of Health $(\mathrm{NHH})$ bij grootschalige clinical trials betrokken. ${ }^{107} \mathrm{Bij}$ de HIV-vaccinstudies blijken de criteria aan de hand waarvan besloten dient te worden of de derde fase van de trial kan worden ingegaan weinig soelaas te bieden. Die criteria zijn nu zelf onderdeel geworden van de discussie en kunnen daarom de discussie niet beslechten.

Bil het onderzoek naar de ontwikkeling van HIV-vaccins zijn verschillende disciplines betrokken, zoals de epidemiologie, de immunologie en de moleculaire biologie. Zoals gezegd neemt de epidemiologie begin jaren tachtig een sterke positie in; epidemiologen hebben methoden om een ziekte te onderzoeken als verder nog weinig bekend is over wat voor een ziekte het mogelijk is. Later staan de laboratoriumwetenschappers (de immunologie in het bijzonder), met de belofte dat zij een vaccin kunnen ontwikkelen, sterker. In het laboratorium blijkt het echter moeilijk om de infectie nader te onderzoeken. Adequate madellen voor dierproeven ontbreken. Epidemiologen kunnen via cohortstudies, waarin mensen die met HIV zijm geinfecteerd in de tijd warden gevolgd, gegevens verstrekken over de ziekteverschijnselen van mensen met HIV. Zo blijft de epidemiologie een rol spelen in het onderzoek naar AIDS. ${ }^{105}$ De disciplines vullen elkaar aan. In de discussie over de verhouding tussen de genetische en de antigene diversitet in relatie tot vaccinstudies zijn de verschillende onderzoeksvragen en methoden van de immunologie en de moleculaire biologie echter een reden waarom het onderzoek stagneert.

\section{.3 Het WHO-netwerk te midden van de controverse}

Het WHO-netwerk start uiteraard niet in een vacuüm. Voor het WHO-netwerk wordt opgericht, worden er nationaal én internationaal gegevens over de diversiteit van HIV verzameld. In de notulen van de tweede vergadering van de werkgroep wordt een korte opsomming gegeven van al bestaande nationale en internationale HIV-databases. Een opmerkelijk verschil tussen de geplande WHO-database en bestaande HIV-bestanden, is dat de WHO zowel de genetische als de antigene diversiteit in kaart wil brengen terwill de andere registraties voornamelijk zijm gericht op de genetische diversiteit van HIV. Een belangrijk vraag. stuk in de controverse over de effectiviteit van HIV-vaccins, namelijk hoe de gene- 
tische diversiteit zich verhoudt to de antigene diversiteit staat zo central in de registratie die de WHO wil opzetten.

Het doel waarvoor de gegevens over de genetische en antigene diversiteit worden verzameld, is bovendien de bevordering van de ontwikkeling van HV-vaccins; de registratie moet informatie opleveren voor onderoek naar effectieve HIV-vaccins.

"The primary purpose of the WHO-network for HIV isolation and" characterization is to establish a wordw wide mechanism for the surweillance of the genetic and antigenic pariation of $H A Y$ so to obtain information of use in the development of vacches agrainst aids". 109

De ontwikkeling van de registratie en de voorbereidingen van de vaccinstudies lopen ook voor een deel samen. In de tijd dat de plannen worden gemaakt voor de opzet van de registratie, selecteent de WHO vier ontwikkelingslanden waar in de toekomst vaccinstudies moeten worden opgezet. De vier landen zijn Oeganda, Ruanda, Thailand en Braziliè. Deze landen worden ook voor de registratie aangewezen om daar als eerste, bij wijze van proef, de diversiteit van HIV in kaart te brengen.

Ten slotte neemt de WHO tijdens de pilotstudy van de registratie een beslissing over het opzetten van vaccinstudies in ontwikkelingslanden. Dat besluit heeft een controversieel karakter. In 1992 besluit de NIH in de Verenigde Staten om de door hen geplande vaccinstudies waarbij grote groepen vrijwilligers gevaccineerd zouden worden, voorlopig niet door te laten gaan. Aan dit besluit is een felle discussie vooraf gegaan over de risico's en belangen van dergelijke studies. Het departement van defensie die zulke grootschalige studies kan opzetten, en de NiH ruziën openlijk over de vraag hoe de zo miljoen dollar van het Congres aan de ontwikkeling van HIV-vaccins moet warden besteed. Hierbij beschuldigen zij elkaar ervan de belangen van de industrie zwaarder te laten wegen dan de volksgezondheid. Ondertussen dreigen aids-activisten de studies te boycotten omdat zij de risico's te groot vinden. Voor een deel van de onderzoekers zijn de tests echter nog cle enige manier om verder te komen in de ontwikkeling van vaccins (zie paragraaf 2). De WHO wordt partij in deze controverse als zil bešluit om, in tegenstelling tot de $\mathbf{N I H}$, de voorbereidingen van de vaccinstudies die zij in ontwikkelingslanden heeft gepland, wel door te laten gaan. Het besluit van de WHO wordt dain ook fel bekritiseerd. 10 Kortom, het WHO-netwerk en de controverse over de effectiviteit van het vaccin raken elkaar op twee cruciale punten, namelijk in de opzet van de registratie om zowel de genetische als de antigene diversiteit van HIV in kaart te brengen en met het besluit van de WHO om, anders dan de NIH, de vaccinstudies door te zetten.

\section{Consensus?}

In de documenten van de technische werkgroep wordt echter over de contro. verse over de effectiviteit wan HIV-vaccins niets vermeld. lemand die alleen de documenten van de werkgroep zou lezen, kan denken dat de ontwikkeling van een HIV-vaccin niet gemakkelijk is, maar zou niet weten hoe omstreden de kwes- 
tie van HW-yaccins is en zou hiet beseffen dat onderzoekers hierower al een tijd in een controverse zijn verwikkeld.

De constatering dat in de vergaderstukken van de technische werkgroep over de problemen bit de onwikkeling wan HIV-vaccins niet wordt gerept, hoeft natuurIijk niet te betekenen dat de leden van de werkgroep het er niet over hebben gehad. Niet alles wat in de wergaderingen besproken is, wordt in de verslagen opgenomen. Het is goed mogelik dat bepaalde onderwerpen bewust niet op papier ziln gezet; zaken die heel vanzelfsprekend zijn en niet genoemd hoeven te worden of zaken die juist moeilijk liggen en daarom niet beschreven worden. Wel kan uit de analyse van de vergaderstukken worden geconcludeerd dat het voor de werkgroep niet van belang is om formeel een standpunt in te nemen in de discussie over de ontwikkeling van HIV-vaccins.

Het ontbreken van sporen van een discussie over de ontwikkeling van HIV-vaccins, zou ook een bewijs kunnen zijn dat de WHO langs een andere weg naar consensus over de wetenschappelike basis van haar beleid streeft. Zoals in de inleiding reeds is opgemerkt kan de WHO riet blijwen twijfelen, zij worden geachi te handelen. Sheila lasanof die onderzoek heeft gedaan naar onderzoekers die de overheid wetenschappelijke adviezen geven voor de ontwikkeling van beleid, heeft beschreven hoe wetenschappelijke kennis wordt gedeconstrueerd als ze de beleidscontext wardt binnengehaald. "Zij laat verschillen zien in de manieren waarop wetenschappers en beleidsmakers kennis presenteren. Wetenschappelijke onderzoekers hanteren bij hun uitspraken een voorzichtige stijl van doen en wijzen uitdrukkelijk op de beperkingen en onzekerheden die aan hun uitspraken kleven. Beleidsmakers hanteren een geheel andere stijl. Beleidsmakers presenteren wetenschappelijke kennis als betrouwbaar en zeker, omdat twiffel de autoriteit van wetenschap en het belang van wetenschap voor de ontwikkeling van beleid zou ondergraven.

Volgens Simon Shackley en Briane Wynne worden de laatste decennia echter ook in beleidsrapporten twijfels en onzekerheden die verbonden zijn aan wetenschappeliik kennis steeds vaker door onderzoekers uitgesproken."12 Het is volgens Shackley en Wynne daarbij wel van belang dat onzekerheid wordt gepresenteerd op een manier die de autoriteit van wetenschap niet ondergraaft. In hum artikel "Representing Uncertainty in Global Climate Change Science and Pölicy" beschrijven zij verschillende manieren waarop onzekerheid over wetenschappeliike kemnis in een beleidscontext wordt gepresenteerd. Ten eerste wordt de onzekerheid van wetenschappelijke kennis in een beleidscontext beheersbaar gemaakt, bijvoorbeeld door marges aan te geven warbinnen die kennis wel zeker is. Ten tweede wordt aan onzekere kennils van nu de belofte verbonden dat in de toekomst, als meer kennis is verzametd, de twijfels zullen worden weggenomen. Ten derde kunnen onzekerheden die aam kennis kleven soms in iets anders, iets respectabels, worden getransformeend. Shackley en Wynne geven het volgende voorbeeld: Twijfels over de voorspellende waarden van een model over klimaatontwikkeling worden weggenomen door te spreken in termen van meetfouten. De twijfels over het model worden daarmee getransformeerd in twijfels over meetresultaten. Het model hoeft daarmee niet te warden opgegeven, 
maar er moeten wel nieuwe metingen worden gedaan. Daavoor is uiteraard neuw onderzoek nodig.

Op de wijze, zoals Shackley en Wynne dat beschreven hebben, worden in de documenten van de technische werkgroep de bestaande onzekerheden over de diversiteit van HIV erkend en direct gekoppeld aan toekomstig onderzek dat de onzekerheden zal wegnemen. Het is volgens de technische werkgroep onzeker of bij de ontwikkeling van vaccins rekening moet worden gehouden met de genetische diversiteit wan HIV. Het is daarom nodig, zo stelt de werkgroep, on meer informatie te verzamelen over de genetische en de antigene diversiteit van HIV.

"As yet, it is not possible to corrolate nudeotide sequence differences with fundamental airal properties such as infectivily, tranmissibility or pathogenicity. Detailed information of the number of distinguishable HV serotypes circulating within different communities is lacking and becatuse the mechanisos for inducing immunity are wnkwow, its is not certain whether effective aids candidate vaccine preparations woll need to conain immunogenis material derived from wival variants geographically associated with a target population, or with phases of the epidemic". 13

Het probleem hoe de genetische en antigene diversiteit zich tot elkaar verhouden wordt gedefinieerd als een informatieprobleem. Er is te weinig bekend over het onderscheid in serotypen en de werking van het immuunsysteem, maar als die kennis er wel is, kan zo wordt verondersteld, de correlatie tussen de genetische en de antigene diversiteit worden bepaald. Dat er onzekerheid bestaat over de verhouding tussen de genetische en de antigene diversiteit van HIV is geen probleem voor het beleid van de WHO, omdat de verwachting bestaat datt er zekerheid komt. De HIV-registratie van het WHO-netwerk zal, zo verwacht de werkgroep, meer informatie leveren over de genetische en antigene diversiteit van HIV. Daardoor zullen de twijfels worden weggenomen en kan de ontwikkeling van een vaccin verder gaan.

In de documenten van de werkgroep wordt de controverse met al haar onzekerheden dus naar de toekomst geschoven. Onzekerheid wordt toegelaten, maar op een manier die het beeld van de wetenschap als een zekere en onafhankelijke basis voor beleid niet aantast. Onzekerheid en discussie over wetenschappelijke kennis worden niet als probleem gezien zolang de belofte er is dat die zekerheid er komt.

Onzekerheid over wetenschappelijke kennis hoeft, zo hebben Shackley en Wynne laten zien, geen belemmering te zijn voor de inzet van wetenschap bij de ontwikkeling van beleid. Sterker, zowel anderzoekers als beleidsmakers kunnen voondeel halen uit een dergelijke explicitering van twijfels. Onzekerheid over de kennis die de basis moet vormen woor het beleid, geeft onderzoekers de moge. lijkheid om meer onderzoek te doen. Het doel wan wetenschappelijk onderzoek vaor beleid wordt dan om onzekerheden verder te reduceren. Beleidsmakers krij* gen meer ruimte om naar oplossingen te zoeken, want ze kunnen zeggen dat eerst meer moet onderzoek worden gedaan voordat verder beleid kan worden 
ontwikkeld. Door te wijzen op de twiffels over wetenschappelike kennis en wooral de erkenning van die twijfels in beleidsrapporten, willen Shackley en Wynne later zien dat de breed gedeelde weronderstellingen over de verhouding tussen wetenschap en beleid die ook door de WHO worden uitgedragen, niet juist zün. Ten eerste is wetenschappelike kennis vaak minder zeker dan wordt gedacht. Ten tweede blijkt twijfel over wetenschappelijke kennis een minder groot probleem te ziln voor die ontwikkeling van beleid. Sterker nog, de samenwerking tussen weitenschappelike onderzcekers en beleidsmakers kan gebaat zijn bij twilftels over de modellen, de gegevens of de canclusies van onderzoek. Onzekerheid over de kennis biedt wetenschappelijke onderzoekers mogelijkheden voor verder onderzoek en geeft de WHO de rumte om de verantwoordelijkheid woor een oplossing van beleidsproblemen te leggen bij het onderzoek. Binnen het WHO-netwerk wordt, zo kan op basis van de officiële vergaderstukken worden geconcludeerd, niet gestreefd naar een gezamenlijk standpunt in de discussie over de diversiteit van HIV in relatie tot de ontwikkeling van vaccins. Zo'n gezamenlijk standpunt blijkt ook niet nodig. Integendeel, onzekerheid over welke kennis nodig is voor de ontwikkeling van HV-vaccins en of die kennis voldoende valide is om besluiten te nemen over de volgende stappen in het tes. ten wan de reeds ontwikkelde vaccins, is een basis woor de samenwerking tus. sen de WHO en de laboratoria. Voordat de WHO besluiten neemt over het opzetten van vaccinstudies, zullen de laboratoria eerst meer gegevens verzamelen. Samen zetten zilj de HIV-registratie op.

\section{.4 De opbouw van het netwerk}

Nu blijkt dat consensus niet de basis is voor samenwerking in het WHO-netwerk, is de vraag wat de laboratoria bindt. Hoe kunnen de laboratoria ondanks al hun verschillen met elkaar samenwerken? Hoe wordt bijvoorbeeld voorkomen dat. zoals in de controverse over de opzet van trials (zie paragraaf 2), de verschillende onderzoeksmethoden en -resultaten met elkaar botsen en een impasse ontstaat?

In navolging van Koenis wordt in deze paragraaf onderzocht hoe binnen het WHO-netwerk het gebrek aari consensus wordt opgevangen. 4 Daabil staat het organisatorisch werk dat is verricht om het WHO-netwerk op te zetten centraal. De vergaderingen, rapporten en infrastructurele voorzieningen worden in deze paragraf beschouwd als de heterogene bindingen van een netwerk. Het gaat echter niet alleen om de bindingen van het netwerk, maar ook om de ordening die daardoor ontstaat tussen actoren in het netwerk. De naam van het WHOprogramma (het WHO-netwerk) mag niet verward worden met het theoretische concept netwerk. Het programma wordt daarom consequent aangeduid met het WHO-netwerk. Zonder "WHO' als toevoeging, wordt "netwerk" gebruikt als een theoretische begrip. Als over actoren in het netwerk wordt gesproken gaat het dan niet alleen om de laboratoria maar ook om andere actoren zoals experimenten, gegevens of beleidsdoelen (zie hoofdstuk 1). 


\section{Tijdens vergaderingen}

Het WHO-netwerk gaat van start met een vergadering. Op uitnodiging van de WHO komen op 11 en 12 december 1989 vertegenwoordigers wan de laboratoria, die later de technische werkgroep gaan vormen, voor de eerste maal bij elkaar. De vertegenwoordigers zullen nog regelmatig met elkaar vergaderen, 20 'n éen of twee keer per jaar, voordat in 1993 het definitteve projectvoorstel aan de stuurgroep voor vaccinontwikkeling, die over de voortgang wan de registratie beslist, wordt voorgelegd.

Het doel van de vergaderingen is om overeenstemming te bereiken over de opzel van de registratie en op basis daarvan afspraken te maken. Hoe belangrijk het komen tot goede afspraken ook wordt geacht, vergaderen wordt zelden gezien als echt werk. Een groot deel van de kritiek op de bureaucratische rompslomp binnen de WHO is dan ook gericht op het vergaderen. In haar serie artikelen over het vijftigjarig bestaan van de WHO stelt Godlee onder andere dat er bin. nen de WHO te veel gepraat en te weinig gedaan wordt.

"In general thowgh, there is lots of activity and lalk but it is not all clear what" they achiene". 175

De wraag is of deze kritiek in alle opzichten terecht is. Er wordt binnen de WHO inderdaad veel tijd aan vergaderingen besteed. Ook het WHO-netwerk is daarvan een voorbeeld. Vaak zal het onduidelijk zijn wat nu precies het resultaat is van de vergaderingen. Dat betekent echter niet dat er geen resultaten zijn. Om de bijdrage van de vergaderingen in de vorming wan het WHO-netwerk te onderzoeken, wordt in deze paragraaf daarom het vergaderen nader bekeken. "1t Voor elke vergadering wordt een agenda opgesteld waarin staat welke onderwerpen zullen worden besproken (en door wie). De agenda vertelt iets over de wijze waarop onderwerpen in de vergadering aan de orde komen. As voorbeeld wordt hier gekeken naar de vergadering in Amsterdam op 18 juli 1993 (zie figuur 2). Volgens de agenda spreken 's morgens de vertegenwoordigers van de labo. ratoria in ontwikkelingslanden die zijn geselecteerd om voor de reglstratie bloed. monsters te verzamelen. Eerst is het de beurt aan de vertegenwoordiger van het Thaise laboratorium. Daama volgen achter elkaar vertegenwoordigers van het Oegandese, Ruandese en Braziliaanse laboratorium. De agenda voor de middag is op dezelfde wijze ingedeeld. Dan is het woord aan de secunciaire laboratoria die het HIV dat uit de bloedmonsters wordt geisoleerd zullen karakteriseren. Om twee uur houdt de eerste spreker een inleiding over de serologische analyse, een half uur later is het de beurt aan de volgende onderzoeker die spreekt over de genetische screening van HIV. Zo gaat de agenda langs alle experimenten om HIV te karakteriseren. Elk onderwerp van de agenda wordt ingeleid waarna een korte discussie volgt. Als de discussie is afgerond komt het valgende onderwerp aan bod. Hoewel de vergadering ongetwijfeld niet strikt volgens de agenda zal verlopen, structureert de agenda wel de wijze warop de bijdragen van de ver. schillende laboratoria aan het WHO-netwerk worden besproken. De opzet van de vergadering is zodanig dat verschillende experimenten en disciplinaire benaderingen niet tegelijkertijd worden besproken, maar achter elkaar. Op deze 
Figuur 2: Een agenda van cen vergadering.

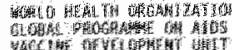

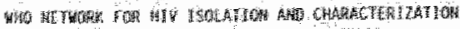

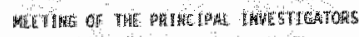

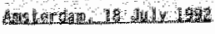

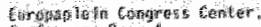

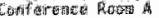

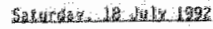

200

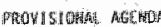

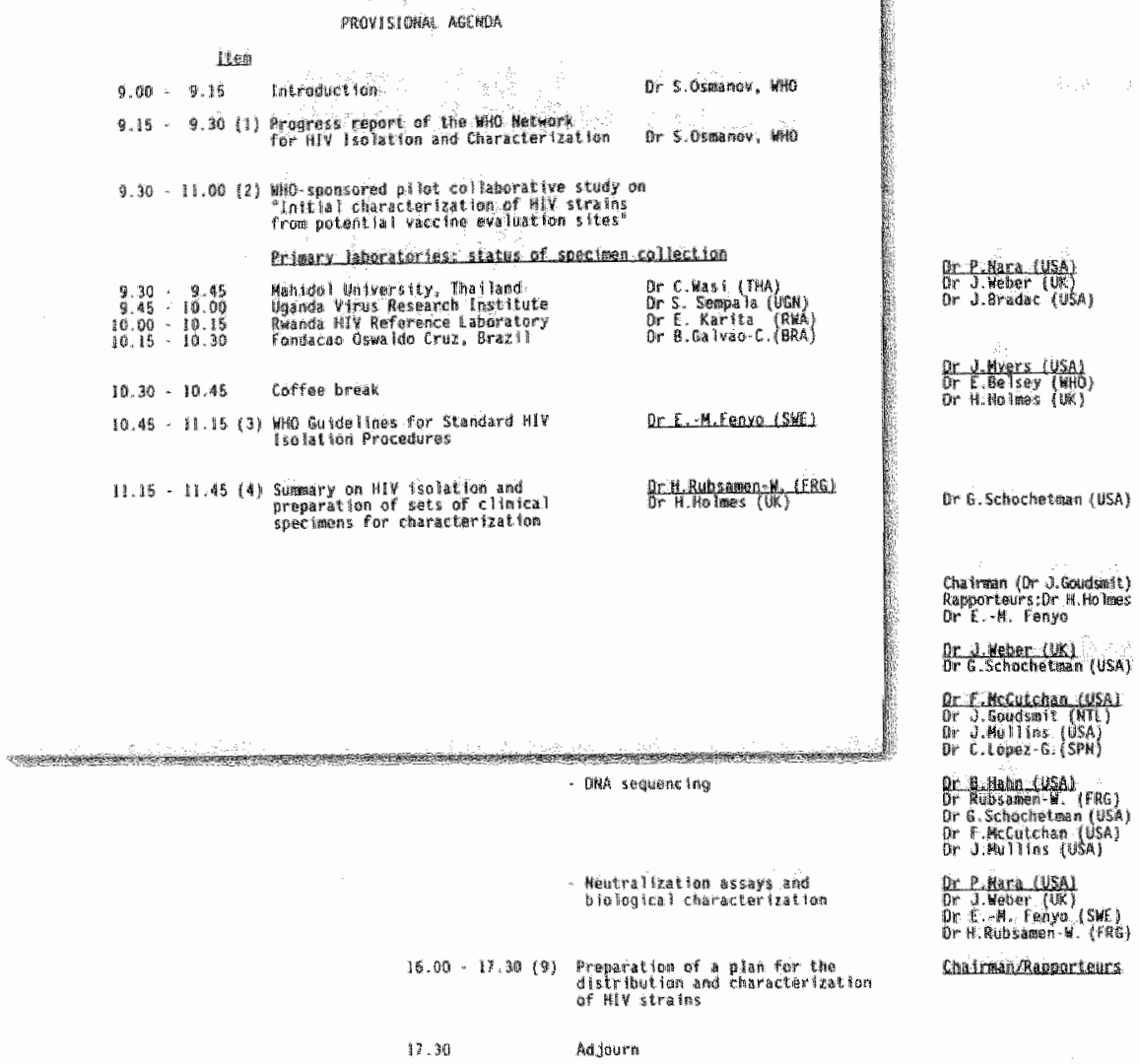

Bron: WHO/GPAOffice of Research (1992b). Report of the principal investigators of the WHO-network for the isolation and characterization of HW. 19-24 july. Amsterdam. 
manier worden de standpunten die in het wetenschappelijke debat tegenover elkaar staan, uit elkaar getrokken, van hun oppositionele karakter ontdaan en naast elkaar geplaatst.

\section{In rapporten}

In de wergaderingen van de werkgroep worden de werschillen in opvattingen over de karakterisering van HV niet verdoezeld. Wel worden ze geordend. De vraag is hoe sterk die ordening is. Of beter gezegd, hoe versterkt de werkgroep de ordening die in de standpunten wordt aangebracht? Een bekende metafoor om over de sterkte van bindingen te spreken is die val een touw. Wat maakt een touw sterk? Een touw is niet sterk omdat er éen sterke streng van begin tot eind loopt, maar omdat het touw bestaat uit vele korte strengen die elkaar overlappen en om elkaar zijn gedraaid. Wanneer deze metafoor voor het functioneren van wetenschap wordt vertaald, dan wechten wetenschappers hun netwerken als een touw uit vele heterogene elementen - mensen en dingen - aar elkaar verbonden door korte lokale lijnen, zonder een enkel allen verbindend element. De rapporten van de technische werkgroep die op basis van de vergaderingen en als woorbereiding van nieuwe vergaderingen worden geschreven vormen zulke extra verbindingen tussen de genetische en antigene diversiteit. Na afloop van de eerste vergadering wordt door één van de leden van de werkgroep een conceptvoorstel geschreven, waarin de opzet van de registratie uiteengezet wordt. Het voorstel omvat onder meer de aanleiding voor de ontwikkeling van de registratie, een kort overzicht van de wetenschappelijke achtergronden van het project, een voorstel voor de organisatie van het WHO-netwerk en een beschrijving van de stappen in de registratie.

Het projectvoorstel wordt in de valgende vergadering, die van 19 tot 21 novem. ber 1990 in Potter"s Bar op het National Institute for Biological Standards and Control (NIBSC) plaatsvindt, besproken. Na afloop van die vergadering wordt een tweede concept geschreven. In vergelijking met het eerste concept verandert er weinig aan de oorspronkelijke opzet van de registratte. Het voorstel wordt op sommige punten aangevuld. Verder ziin vooral tekstuele wijzigingen doorge. voerd.

Toch wordt het woorstel uiteindelijk nog vilif keer herschreven. De onderzoekers in het WHO-netwerk besteden veel tijd aan de 'juiste' tekst van het rapport. Geen wonder dat gegeven al die inspanning om het juiste woord te vinden de onderzokers elkaar complimenteren over de wijze waarop het eindrapport is geschreven.

"T have revticwed the draft report of the WHO vechnical working group on $\mathrm{HW}$ isolation and characterization and consider it to be very complete and extremely sell arilien" $" 17$

Waarom hechten de onderzoekers zoveel belang aan het herschrijven van het rapport als het voorstel in grote lijnen niet verandert?

In het wetenschapsonderzoek wordt veel aandacht besteed aan de rol van tek. sten in onderzoek. Tijdens onderzoek worden tal van zaken op papier gezet in 
de vorm van registraties, tabiellen, grafieken, papers, artikelen en leerboeken. Wanneer de verschillende inscripties naast elkaar worden gelegd, valt op dat de stijl van schrijven verandert. Als een bepaalde uilspraak of claim van een labjournaal naar een wetenschappelike artikel en een leerboek gaat, wordt de stijl steeds algemener, minder persoonlijk en minder lokaal. "18 Daamaast worden inscripties door een onderzoeker gekoppeld aan andere inscripties, bij voorkeur inscripties waarin opvattingen, experimenten of technieken zijn vervat die algemeen warden geaccepteerd. Whe de beweringen van de onderzoeker nu bestrijdt, bestrijdt ook deze andere opvattingen. Waar een afzondertike claim eenvoudig amvergeblazen kan worden, wordt de ineengewikkelde streng van elementen een anbreekbaar touw. Deze beide verschijnselen - losmaken van de lokale context en verbinden rnet andere opvattingen - komen we ook tegen in de rapporten van de werkgroep.

Als de verschillende versies van het projectvoorstel die in de vergaderingen van de werkgroep ter sprake komen naast elkaar worden gelegd, dan wordt een verschuiving zichtbaar in de silil van schrijven: de uitspraken worden net als in wetenschappelijke teksten algemener. Als voorbeeld neem ik de doelstelling van het WHO-netwerk in de opeenvolgende versies van het projectvoorstel.

"The purpose of the proposed WHO global Network for HIV Isolation and Characterization is to establish a world-wide surveillance mechanism for the genetic and antigenic variation of HIV". 119

2 "The primary purpose of the WHO Network for HIV isolation and Characterization is to establish a world-wide mechanism for the surveillance of the genetic and antigenic variation of HIV so as to obtain information for use in the development of vaccines against AlDS".120

3 "In order to correlate the genetic, antigenic and biological properties of HIV strains, the Global Program on AIDS (GPA) of the World Health Organization (WHO) has initiated a WHOnetwork for HIV isolation and Characterization which will require a well-coordinated and integrated international effort". ${ }^{*} 1$

4 "A well-organized, integrated effort by many laboratories will be required to correlate the genetic, antigenic, and biological properties of HIV isolates. The establishment of a WHO-network for HIV isolation and characterization by GPA has been an important step towards this goal". 122

Het verschil tussen de eerste en de tweede versie is dat in de eerste de opzet van het WHO-netwerk een voorstel is: "the proposed WHO Global network (...)". In de tweede versie is geen sprake meer van een voorstel, maar wordt gesproken over het WHO-netwerk. Bovendien wordt het WHO-netwerk gekoppeld aan het WHO-programma voor de ontwikkeling van HIV-waccins. Door die koppeling wordt het belang van het WHO-netwerk groter. Als het WHO-netwerk niet wordt opgericht, zal er geen informatie zijn voor de vaccinstudies en stagneert de ver- 
dere ontwikkeling van een HIV-vaccin. In de derde versie wordt de doelstelling van het WHO-netwerk verbonden met het gehele aids beleid van de WHO, the "Global Program on AIDS". Bovendien wordt de verhouding tussen de opzet van het WHO-netwerk en het doel om de genetische en de antigene diversiteit vam HIV in kaart te brengen omgedraaid. In de eerste versie van het rapport is het doel om de diversiteit van HIV in kaart te brengen en wordt daarvoor het WHOnetwerk opgericht. In de derde versie kan zonder het WHO-netwerk de genetische en antigene diversiteit niet eens in kaart worden gebracht. In de laatste versie wordt dit nogmaals versterkt en wordt het WHO-netwerk de enige manier om de diversiteit van HIV in kaart te brengen. Zonder een geïntegreerde aanpak door verschillende laboratoria is het niet mogelijk de diversiteit van HIV in kaart te brengen. In de tekst van het rapport wordt het WHO-netwerk bovendien aan andere programma's en doelstellingen van de WHO gebonden en wordt het daardoor steeds vanzelfsprekender dat de antigene en de genetische diversiteit van HIV in kaart worden gebracht als voorbereiding op vaccinstudies.

Niet iedereen is het eens met de opzet van het WHO-netwerk. Twee onderzoekers trekken de verbinding tussen het WHO-netwerk en de vaccinstudies in twijfel. In een brief aan de werkgraep schrijuen zij:

"What we are most concerned about is that a great deal of the GPA's money and our laboratory effort might be spent in generating wolumes of data that will certainly lead to scientific publications but may not lead to better understanding of HIV [...]. If we feel that there really is some research we could do that will tot simply bring money into our laboratory but might realistically help towards vaccine evaluation, then we shall send you a short proposal of the type you are requesting". 123

Deze onderzoekers voeren uitspraken over het belang van het WHO-netwerk als het ware terug naar de "productieomstandigheden" - naar de individuele onderzoekers en hum interesses en maakt daamee het WHO-netwerk tot een verzameling laboratoriumexperimenten die, als ze in de huidige vorm worden uitge. voerd, geen verdere relevantie hebben. Met de voor onderzoekers zo fundamentele doelstelling van "een beter begrip van de aard van HIV' worden de doelstellingen van de werkgroep in de flank geramd. Alleen beter begrip van HIV kan leiden tot zinvolle evaluatie van vaccins.

Door de resultaten van onderzoek aan andere onderzoeken, instrumenten en wetenschappelijke theorieèn te verbinden worden uitspraken harder en wordt het moeilijker ze te bekritiseren. In beleidsrapporten, zo blijkt uit bovenstaande analyse, gebeurt jets soortgelijks. Het WHO-netwerk wordt aan steeds globalere doelstellingen zoals het vaccinbeleid en uiteindelijk het "Global Program on Aids" gekoppeld; doelstellingen die minder en minder in twijfel te trekken zijn in hun belang voor de globale gezondheidszorg.

Met het schrijwen en herschrijven van het projectvoorstel, waarbij een steeds algemenere formulering wordt gepaard aan associatie met globale beleidsdoelen, wordt overeenstemming bereikt over de opzet van het WHO-netwerk zonder dat inhoudelijke tegenstellingen de woortgang in de weg staan. In de opeen. 
yolgende verstes wan het voorstel wordt het WHO-newerk zo steeds steviger ingebed. Wie in 1992 de oprichting van het WHO-netwerk ter discussie stelt, heeft dadmee ook krittek op het "Global Program on Aids" en zal met sterke argumenten moeten komen om gehoord te worden.

\section{Langs de infrastructuur}

Een rapport kan worden gezien als êen van de organisatorische bindingen die het WHO-netwerk bij elkaar houdt. Ook de infrastructuur die voor het WHO-netwerk wordt opgebouwd kan 20 worden bekeken. In plaats van de infrastructuur te beschouwen als een voorziening nodig voor het transport van de bloedmonsters, kan deze ook worden gezien als een bindmiddel dat samen met andere bindmiddelen het gebrek aan gemeenschappelijke opvattingen ondervangt (zie paragraaf 4 , hoofidstuk 1). 124

In de vergaderingen wan de werkgroep wordt afgesproken dat de WHO een infrastructuur zal opbouwen voor het transport van de bloedmonsters van de primaire haar de secundaire laboratoria. Ook worden de voorzieningen van de primaire laboratoria om bloedmonsters te verzamelen en te bewaren verbeterd. De opbouw van de infrastructuur wordt beschouwd als onderdeel van de voorbereidingen voor de opzet van de registratie; als een randvoorwaarde voor het project. De infrastructuur heeft een tweeledig doel. Enerzijds het transport, anderzijds de kwaliteitsgarantie van het bloed. Voor de instandhouding van de kwaliteit van de bloedmonsters is het belangrijk dat de reistijd zo kort mogelijk is - in ieder geval minder dan 72 uur - en dat de omstandigheden waaronder het bloed wordt verwoerd zo optimaal mogelijk zijn. De bloedmonsters mogen niet te warm of te koud worden dan wel besmet raken met andere ziektekiemen. De grootste zorg van de technische werkgroep is dat het bloed, dat met veel moeite is verzameld, onbruikbaar blijkt als het eenmaal bij de secundaire laboratoria is aangekomen.

"It should be emphasized that the success of this program zend be criticaily dependent upon the availability of high-quality divical specimens stored under optimal conditions". 125

Aan de opbouw van de infrastructuur wordt dan ook veel zorg, tijd en geld besteed.

De infrastructuur kan ook worden gezien als een keten die de laboratoria in het WHO-netwerk aan elkaar verbindt. De keten begint bij de primaire laboratoria die dankzij een investering van de WHO beschikken over een zogenaande koude keten van koelkasten, wriezers, noodgeneratoren voor de opwekking van elektriciteit en "koud ijs". Het principe van een koude keten is dat deze niet verbroken mag worden. Als bijwoorbeeld de elektriciteit uitvalt, moeten er generatoren zijn die er voor zorgen dat de koelkasten en vriezers blijwen functioneren.

De WHO levert de primaire laboratoria ook materialen om het bloed te verpakken voor transport. Het bloed wordt in verschillende lagein verpakt. De bimmen. ste laag is een plastic buisje warin het bloed wordt bewaard. Het buisje is wan plastic omdat glas te gemakkelijk breekt. Het buisje wordt in tissue papier gewik- 
keld dat eventueel gelekt bloed kan absorberen. Om het papler wordi nog een plastic zakje gedaan om te voorkomen dat gelekt bloed een ander monster kan besmetten. Ten slotte wordt het buisje in een container geplaatst. De verpakking zorgt er voor dat de omstandigheden onderweg, net als in het laboratorium, constant blijuen.

"Place plastic bags into a condaine" that protects from phystical dawage, temperature and pressure fluctuations."126

De bloedmonsters kunnen in principe gewoon per post worden verstuurd. Dat is relatief gemakkelijk omdat er dan weinig formaliteiten zijn waaraan behoeft te worden voldaan. De omstandigheden waaronder postpakketjes worden ver woerd, kunnen echter niet optimaal worden gecontroleerd. Bovendien is het risico groter dat de bloedmonsters te lang onderweg zijn. Luchttransport is daarom volgens de WHO beter. De omstandigheden wan het bloed kunnen dan voortdurend in de gaten worden gehouden. Zelfs in het vliegtuig en op het vliegveld worden de 'laboratoriumcondities' gehandhaafd.

"Through the WHO Shipping Services, arrangements have been made for the expeditious shipment, recourery at the airport and delizery of specimens to the birus isolation laboratories at Georg-Speger-Haus in Frantefurt and al NIBSC in London".127

Dankzij de aaneengesloten keten binnen en tussen laboratoria kan het bloed over de hele wereld worden vervoerd zonder dat het de cocon van het laboratorium hoeft te verlaten. De locatie van het laboratorium wordt als het ware uit-

gebreid tot over de hele wereld. 128 Van een verzameling laboratoria wordt het WHO-netwerk een laboratorium dat zich over de hele wereld uitstrekt. Zadra een bloedmonster buiten de keten komt, omdat bijvoorbeeld de verpakking kapot gaat of het per ongeluk naar een verkeerd adres is opgestuurd, gaan de bloedmonsters vertoren en is de karakterisering wan HIV niet mogelijk.

\section{Via bloedmonsters}

Dankzij de infrastructuur kunnen de bloedmonsters langs de laboratoria van het WHO-netwerk worden verzonden en worden de laboratoria vit verschillende delen van de wereld en verschillende wetenschappelijke disciplines met elkaar verbonden.

Voor de technische werkgroep is het land waar de bloedmonsters vandaan komen, hun oorsprong, ëẻn van de belangrijkste elementen in het WHO-netwerk. De werkgroep gaat er vanuit dat secundaire laboratoria bereid zijn om mee te werken aan het onderzoek omdat de WHO over zulk uniek materiaal beschikt.

"These specialized Laboratories are likely to be attracted by the uniqueness of the samples available through WHO (...)".129

Wat maakt de bloedmonsters van het WHO-netwerk zo uniek? De bloedmonsters zijn bijzonder, maar dat is niet omdat de bloedmonsters voor laboratoria in Europa en de Verenigde Staten wit verre en onbereikbare landen komen. Ook 
zonder de WHO kunnen de Europese en Amerikanse laboratoria bieschikken over bloedmonsters uit landen in Afrika en Azie. In haar artikel schrijt Hellen Epstein over haar evaringen met aids-onderzoek in Deganda. Zij beschrifft hoe de wriezers van het laboratorium waar zill werkt, vol liggen met bloedmonsters van HIVgeinfecteerden. Over de HIV-geinfecteerden die bloed hebben afgestaan, zijn ook allerlei gegevens verzameld over bijvoorbeeld hun leeftij, geslacht, religie, bercep, inkomen en seksuele partners. De bloedmonsters zijn wel verzameld, maar nog nooit onderzocht. 30 Voor het WHO-netwerk worden nileuwe bloedmonsters verzameld en wordt geen gebruik gemaakt van bloedmonsters die al voor eerder onderzoek in die landen zijn verzameld. Worden de al bestaande bloedmonsters wellicht niet gebruikt ondat er te weinig over de donoren bekend is? Of is de kwaliteit niet goed genoeg? De gegevens die over de genoemde Degandese bloedmonsters bekend zijn, komen overeen met de gegevens die over de bloedmonsters van het WHO-netwerk zullen worden verzameld rie hoofdstuk 3). De kwaliteit van de bloedmonsters kan natuurlijk een probleem zijn, maar er wordt voor het WHO-netwerk niet eens bekeken of er al bloedmonsters zijin verzameld, die voor de registratie gebruikt kunnen worden. Dit terwijl, zo zal in hoofdstuk 3 blijken, het zo veel moeite kost om de bloedmonsters te verzamelen.

Voor de technische werkgroep is het belangrijkste oogmerk dat de bloedmon sters zuiver blijven, dat wil zeggen: de bewerkingem die het bloed ondergaat in het laboratorium mogen er niet toe leiden dat de kenmerken van het virus veranderen. Zo makt de technische werkgroep zich zorgen over de vraag of de wijze waarop virussen worden geisoleerd het virus in het bloed niet verandert. In dat geval zouden de resultaten van het onderzoek waardeloos zijn.

"rolation procedures may greatly influence the biologic, and perhaps antigenic, properties of virus isolates, therefore the use of a standard HIV isolation achnigue for comparative optidemiological studies is mandalory".13!

De kwaliteit van de reeds verzamelde bloedmonsters kan een reden zijn om alleen met bloedmonsters te werken die binnen het project verzameld zijn.

De zorg dat de kenmerken van het virus niet veranderen, staat echter in contrast met de vele bewerkingen wan het bloed vanaf het moment dat het bloed wordt afgenomen tot en met de karakterisering van het bloed door de secundaire laboratoria. Er worden chemicalièn aan het bloed toegevoegd bijvoorbeeld om stolling tegen te gaan. Het bloed wordt gecentrifugeerd om de bloedcellen te scheiden van het plasma en bepaalde cellen uit het bloed worden tot deling aangezet om het virus te isoleren.

Een bloedmonster is niet alleen onderzoeksmateriaal voor de secundaire laboratoria, het is ook een verbinding tussen de laboratoria. De laboratoria stellen heel verschillende eisen aan het bloed. Een bloedmonster kan nooit aan al die eisen voldoen. Voor de karakterisering van HIV wordt het bloed daarom opgedeeld in bloedproducten (verschillende bloedcellen, plasma en viruskweken) die elk aan andere eisen van de secundaire laboratoria voldoen. Dankzii de bewer. 
king van het bloed kunnen in de secundaire laboratoria verschillende bloed producten worden onderzocht die wel allemaal hetzelfde vertegemwoordigen, namelijk het virus in het bloed van én en dezelfde persoon 132 De wije waarop het bloed is bewerkt, dat wil zeggen geschikt is gemaakt voor de experimenten die de betrokken laboratoria willen doen; is van belang.

Zoals de agenda van de vergadering de standpunten uit het debat over de betekenis van de genetische diversiteit voor de ontwikkeling van het HIV-vaccin naast elkaar plaatst en de infrastructuur het mogelijk maakt dat de verschillende experimenten naast elkaar kumnen worden uitgewoerd (en nog wel onder dezelfde omstandigheden), overbruggen de bloedproducten de verschillende eisen die de secundaire laboratoria aan hun onderzoeksmateriaal stellen, zodat de laboratoria hetzelfde virus kunnen onderzoeken zonder dat zil met hetzelfde materiaal hoeven te werken. Het is dit complex van eigenschappen die de bloedmonsters van het WHO-netwerk zo uniek maken.

\section{Zonder consensus verder}

Consensusvorming is een belangrijke beleidsdoelstelling van de WHO. Alleen door internationale overeenstemming te bereiken over de vraag hoe gezond. heidsproblemen kunnen worden aangepakt, alleen door gezamenlijke actie van lidstaten kunnen fundamentele gezondheidsproblemen worden opgelost. De WHO heeft echter geen transnationale autoriteit en kan lidstaten niets tegen hun zin opleggen. Zij kan alleen met overtuigingskracht consensus bewerkstelligen. Dat de WHO geen dwang kan uitoefenen, 15 echter niet de enige reden waarom zij consensus zo belangrijk acht. In het algemeen wordt consensus als moodzakelijk gezien om mensen of landen aan elkaar te binden. Beleid en maatschappelijk handelen wortelen idealiter in goede wetenschappelijke kennis. Van echte kennis kan, zo meent men in brede kring, pas worden gesproken wanneer de deskundigen het met elkaar eens zijn. Zolang dat niet het geval is, is er eerder sprake van meningen dan van kennis. Om die reden is consensus in de ogen van de WHO een belangrijke basis voor internationale samenwerking. Om die reden vindt niet alleen de WHO, maar vinden ook haar critici bevordering van professionele of wetenschappelijke consensus een belangrijke taak van de WHO.

"Since its foundation, WHO has been the world leader in formulating professional consensus, setting international technical norms and defining health care slandards" "133

Het bevorderen van een dergelijke consensus maakt de weg vrij voor rationeel gezondheidsbeleid.

Ondanks het gebrek aan een gemeenschappelijk doel en gemeenschappelijke uitgangspunten, slagen de laboratoria in het WHO-netwerk er toch in om samen een plan te ontwikkelen voor een registratie van de genetische en antigene diversiteit van HIV. in de vergaderingen van de werkgroep worden de experimenten om de genetisch en de antigene diversiteit in kaart te brengen als aparte onderwerpen besproken. Op die manier wordt de discussie over de verhouding tussen de genetische en de antigene diversiteit gemeden; de experimenten worden 
net tegenover elkar maar nast elkat geplaatst. In de opeenvolgende versies van het conceptyoorstel wordt bovendien het doel van het WHOnetwerk om de antigene en de genetische diversiteit van HIV in kaart te brengen, steeds moeilijker te bekritiseren. lemand die de doelstelling van het WHO netwerk ter discussie wil stellen, vindt eerst alleen de technische werkgroep tegenover zich, maar later ook de staf wan het 'Global Programme on Aids' en de vaccinstudies. De bloedmonsters en de infrastructuur maken het ten slotte mogelijk om HIV langs de verschillende laboratoria te sturen die elk of de genetische dan wel de antigene diversiteit in kaart brengen, maar samen zowel de genetische als de antigene diversiteit.

Waar op wetenschappelijke congressen en in wetenschappeiijke tijdschriften een controverse ontstaat over de diversiteit wan HW en de effectiviteit wan het vaccin, maakt de technische werkgroep een plan om zowel de genetische als de antigene diversiteit van HW in kaart te brengen. Binnen het WHO-netwerk wordt echter geen consensus gevormd over de verhouding tussen de genetische en de antigene diversiteit. Een dergelijke consensus blijkt ook niet nodig om binnen het netwerk aan het werk te gaan. Nevenschikking maakt dat de controverse die buiten het netwerk woedt hier geen functie heeft. Organisatorische en infrastructurele bindingen complementeren deze nevenschikiking en zorgen ervoor dat zonder consensus een florerende praktijk van de grond kan komen.

Het WHO-netwerk wordt opgezet te midden van een controverse over de effectiviteit van het HIV-vaccin. In die controverse staat bijha alles ter discussie en is men het nagenoeg over niets eens. Er bestaat onenigheid over wat de specifieke kenmerken zijn van HIV en of die kenmerken een probleem vormen voor de effectiviteit van een vaccin, over wat de effectiviteit is van de vaccins die reeds ontwikkeld zijn (schattingen liepen uiteen van o\% tot $80 \%$ ) en over de methode om die effectiviteit te meten (wat zeggen laboratoriumstudies aver de risi. co's van klinische effectstudies?).

In de documenten van de technische werkgroep blikt echter dat de opzet en het doel van het WHO-netwerk op geen enkele manier controversieel zijn. De opzet van de registratie raakt de controverse echter wel. De bedoeling van het WHO-netwerk is immers om zowel de genetische als de antigene diversiteit van HIV in kaart te brengen. Bovendien neemt de WHO over de voortzetting van de vaccinstudies een duidelik maar controversieel standpunt in. Als de NHH in 1993 besluit om de vaccinstudies voorlopig uit te stellen, zet de WHO de voorbereidingen voor de vaccinstudies in Oeganda, Ruanda. Thailand en Brazilië voort. Dit hoofdstuk laat zien dat in het WHO-netwerk de controverse over de diversiteit van HIV en de effectiviteit van het vaccin niet afwezig is "maar een andere vorm heeft gekregen nu het de beleidscontext van de WHO wordt binnenge. haald. Wetenschappelijke onderzoekers voeren experimenten uit, schrijven wetenschappelijke artikelen of gaan naar congressen. Binnen het WHO-netwerk 
komen zij echter bijeen in wergaderingen en schrijven ze rapporten: Als het netwerk verandert, verandert ook de stijl van de controverse. Anders gezegd, als de controverse over de effectiviteit van HIV de beleidscontext wardt birnengehaald, veranderen de verhoudingen tussen de standpunten. In platats van posities te bepalen en de verschillen in methode, theorie of opvatting tegenover elkaar te stellen zoals in de wetenschap gebruikelijk is, worden potentiele en bestaande verschilpunten nevengeschikt.

In de vergaderingen worden de verschillende benaderingen van de laboratoria om de diversiteit wan HW te onderzoeken los vari elkaar besproken. Via het schrijven en herschrijven wan rapporten lossen de laboratoria niet alleen het probleem op hoe het project zal worden opgezet, maar gebeurt dat ook zonder dat inhoudelijke verschillen in de weg staan. Bovendien wordt het WHO-netwerlk stevig ingebed door de registratie aan andere programma's van de WHO of algemenere beleidsdoelstellingen te verbinden. Wie de opzet van het WHO-netwerk ter discussie stelt, windt niet alleen de laboratoria tegenover zich, maar ook het "Global Program on Aids" en de hoge aidsincidentiecifers in ontwikkelingslanden. Dit lijkt op het eerste gezicht vooral een procedurele oplossing die de inhoudelijke meningsverschillen niet oplost (en daarom geen echte maar alleen een schijnoplossing kan ziin). Consensus blijkt echter niet nodig. De laboratoria wor. den niet door een gezamenlijk standpunt aan elkaar verbonden, maar via vele heterogene bindingen. Zoals in vergaderingen de verschillende experimenten naast elkaar zijn besproken (een eerste binding), worden ook experimenten in het WHO-netwerk nast elkaar uitgevoerd (een iweede binding). Zo wordt de materiële infrastructuur die voor het WHO-netwerk wordt opgezet, een belang* rijke binding tussen de laboratoria. Op de eerste plaats is infrastructuur nodig (een derde binding) om thet bloed, dat door de primaire laboratoria is werzameld, langs alle secundaire laboratoria te kunnen sturen om op verschillende manieren HIV te karakteriseren. Op de tweede plaats moet de WHO een oplossing vinden woor het probleem dat de laboratoria heel verschillende eisen stellen aan het materiaal dat zij voor die karakterisering nodig hebben. In plaats van bloedproducten te ontwikkelen die aan de minimumeisen van alle labora. toria voldoen, maakt het depot voor de laboratoria toegesneden bloedproducten (bloedcellen, plasma, viruskweken). De laboratoria hoeven niet hetzelfde materiaal te onderzoeken om samen dezelfde virussen te kunnen karakteriseren. De bloedproducten zijn flexibel genoeg om aan de azonderijke eisen te voldoen en tegelijkertijd stabiel genoeg om hetzelfde te kunnen vertegenwoordigen (een vierde binding).

Als resultaat van de opbouw van het netwerk waarin de laboratoria via verga. deringen, rapporten, infrastructuur en bloed met elkaar verbonden zijn, wordt het ontbreken van consensus opgevangen.134 De WHO wordt geprezen vooir haal vermogen om consensus te ontwikkelen, maar de wijze waarop de technische werkgroep het voorstel voor een registratie-netwerk rond HIV ontwikkelt, laat juist zien dat de werkgroep effectief kan zijn zonder dat consensus wordt gevarmd over de verhouding tussen de genetische en antigene diversiteit en de voortzetting van vaccinstudies. 


\section{hoofdstuk 3:}

\section{Registratiewerk}

\section{Hoe HIV de vorm krijgt van een RNA streng}

"Truth is a perishable commodity; considerable care must be exercised in shipping it across the world . $^{3} 135$

\section{.1 Introductie}

De WHO ziet zichzelf als een organisatie die de ontwikkeling van wetenschappelijke kennis initieert en faciliteert, maar zich niet bemoeit met de inhoud van onderzoek. Conform dat zelfbeeld brengt de WHO onderzoekers uit diverse landen bij elkaar om kennis uit te wisselen en tot een gezamenlijk standpunt te komen. In het vorige hoofdstuk is naar voren gebracht dat over de betekenis van de genetische diversiteit voor de antigene kenmerken van HIV geen zeker-

heid bestaat. Daarmee is ook de effectiviteit van een vaccin onduidelijk. Het opzetten van trials om de effectiviteit van vaccins te testen, het uiteindelijk doel waarvoor de WHO gegevens verzamelt over de diversiteit van HIV is zelfs controversieel te noemen. Tegen die achtergrond slaagt de WHO er desalniettemin in een netwerk op te zetten watin laboratoria met een verschillende disciplinaire signatuur samen een registratie ontwikkelen om de genetische en de anti. gene diversiteit wan HIV in kaart te brengen. De oprichting van het "WHO-netwerk voor Isolatie en Karakterisering van HIV" ondersteunt het idee dat consensus geen noodzakelijke voorwaarde is voor vruchtbare samenwerking birmen de WHO. De kracht van de WHO is nu juist om de afwezigheïd van consensus met andere middelen op te vangen. Het is niet zo zeer een gedeelde overeenstemming die de laboratoria aan elkaar bindt als wel de vergaderingen, rapporten, commissies en voorzlieningen van de WHO. Het totale proces van het opzetten wan het WHO-netwerk illustreert bovendien dat de WHO, ondanks een zelfbeeld van een uitsluitend technische organisatie, wel degelijk invloed heeft op de inhoudelijke ontwikkeling van wetenschappelijke kennis. De WHO is meer dan een facilitator. De WHO heeft die invloed door het kader van vergaderingen en voorzieningen dat zij aanbiedt en niet via directe inhoudelijke interventies (zoals het formuleren van inhoudelijke opvattingen).

Met dit inzicht als uitgangspunt mag worden verwacht dat er nog meer manieren zijn walrop het werk van de WHO is verweven met de ontwikkeling van ken- 
nis en de verhouding tussen disciplines. Om die manieren nader te analyseren is het nodig meer in detail te onderzoeken welk werk de technische werkgroep heeft vericht. Daarbij richt ik mij in dit hoofdstuk specifiek op vragen over het proces wan registreren.

Hoe wordt ex precies geregistreend? Bij een registratieproces denken veel mensen hoofdzakelik aan de invoer wan gegevens in een database. ${ }^{36}$ Ze gaan er dan impliciet vanut dat de gegevens voor de registratie al min of meer klaar liggen am te worden ingevoerd. Men gaat met andere woorden uil van het empiristische idee dat waarnemingen en de daarvan afgeleide feiten onproblematische entiteiten zijn. De kern van deze opvatting komt men tegen in de gebruikelijke termen waarmee het registratieproces wordt beschreven: gegevens verzamelen, data controleren en analyseren.

Het moderne wetenschapsonderzoek laat zien dat de productie van kennis aanzienlijk meer werk vereist dan wordt gedacht. In het verlengde van het werk van Latou, Star en Bowker wordt in dit hoofdstuk daarom het accent gelegd op het registratiewerk dat wordt verricht woordat er gegevens zijn die kunnen worden ingevoerd. ${ }^{37}$ Concepten als mobiliseren, stabiliseren en cambineren die in hoofdstuk 1 zün geîntroduceerd (zie aldaar paragraaf 4) zullen worden gebruikt om inzicht te krijgen in dat werk. Dergelijke concepten kunnen daarnaast ook inzicht geven in transformaties die plaatsvinden tijdens het proces van registreren. Met dit conceptuele gereedschap in handen kunnen dan vragen aan de orde komen als: Wat is het effect van registreren voor het object van registratie? Hoe ontwikkelen zilch de onderlinge verhoudingen tussen de laboratoria en het beleid van de WHO?

In dit hoofdstuk wordt de reis gevolgd die gegevens maken vanaf het punt waar ze voor het eerst worden ingenomen tot aan hum eindbestemming in de database. De reis van de gegevens begint in de primaire laboratoria die bloedmonsters verzamelen (paragraaf 2), voert langs een centraal depot (paragraaf 3 ), vervolgt de tocht via de secundaire laboratoria (paragraaf 4) om te eindigen bij de database van het Los Alamos National Laboratory (LANL). Het is deze tocht die in de volgende paragrafen zal worden gereconstrueerd. Net als mensen die een reis maken en daardoor kunnen veranderen zullen ook deze gegevens tijdens hun reis veranderen. Ze doen, net als mensen, indrukiken op.

\section{.2 Van een ver land}

Om de diversiteit van HIV in kaart te brengen wordt als eerste stap een aantal landen geselecteerd waar bloedmonsters van seropositieve vrijwilligers zullen worden verzameld. Dat bloed wordt gekarakteriseerd en de resultaten daarvan worden opgeslagen in een database. op basis van een analyse van de opgeslagen gegevens tracht men inzicht te krijgen in de verhouding tussen genetische en antigene diversiteit van HIV. Zo moet duidelijkheid worden verkiregen over de voorwaarden voor en mogelijkheden van vaccinstudies im de landen waar het bloed is verzameld. 


\section{De selectie vam landen}

De opbouw van de registratie start dus bij de selectie van een aantal landen. De wijze waarop de landen war de verzameling van bloedmonsters tal plats: vinden worden geselecteerd, maakt direct drie kenmerkende aspecten van registreren zichtbaar:

1. Het werk dat wordt werricht om gegevens te produceren in termen van mobiliseren, stabiliseren en combineren; 138

2 Het belang van reeds bestaande classificaties, infrastructurele voorzie. ningen en praktijken waarop wordt voortgebouwd bij het registreren; 139

3 Veranderingen van het registratieobject tijdens het registratieproces. ${ }^{4} 40$

Elk vari deze aspecten zal hieronder aan cle orde komen.

Doel van de registratie is om de diversiteit van HIV wereldwijd in kaart te brengen. Daarvoor hoeft de werkgroep niet de hele wereld af te reizen om overal virussen te isoleren en te karakteriseren. Het is voldoende om een beperkt aantal representatieve landen te selecteren waar de diversiteit van HIV in kaart wardt gebracht. Welke landen kiest de werkgroep en hoe weet de werkgroep dat zij daarbij de juiste keuze heeft gemaakt?

Zoals bij al het wetenschappelijk onderzoek begint de technische werkgroep de ontwikkeling van de registratie niet helemaal wanaf de grond, maar bouwt zij voort op eerder onderzoek , bestaande infrastructuren en al gevestigde praktijken. " $^{\prime \prime}$ De wereld die de werkgroep in kaart will brengen is bijvoorbeeld door epidemiologen al ingedeeld in risicogroepen. De belangrijkste risicogroepen voor besmetting met HIV die epidemiologen onderscheiden zijn homoseksuele mannen, intraveneuze druggebruikers, prostituees en mensen met wisselende seksuele contacten. ${ }^{42}$ Aan de hand wan deze risicogroepen hebben epidemiologen de wereld ingedeeld in een aantal gebieden:

1 Amerika en Europa waar homoseksuele mannen de belangrijkste risicogroep vormen;

2 Zuid en Latijns Amerika waar biseksuelen en druggebruikers de grootste risico-groep zijn;

3 Azië met prostituees en druggebrükers als risicogroepen;

4 Afrika, waar de meest typerende risicogroep bestaat uit mensen die weg wan huis zijn (zoals vrachtwagenchauffeurs of mensen die naar steden trekken op zoek naar werk). 143 In Afrika ziin ook opvallend veel vrowwen via heteroseksueel contact besmet met Hiv.144

Deze epidemiologische referentiepunten vormen het kader om de landen te kiezen waar de diversiteit van HIV in kaart zal worden gebracht. Daaraan kumnen bepaalde zekerheden worden ontleend. ${ }^{145}$

"WHO anticipates the eventual ned for appraximately 12 primary laboratories, located in geographical widely dispersed" countries and representative of different epidemiological palterns.".46 
De werkgroep neemt zich voor de landen te selecteren op de geagrafische spreiding en de epidemiologische variëteit. Bij de elgenlijke selectie van landen blikt echter nog een ander chterium mee te spelen, namelik de voorzieningen voor bloedonderzoek die al in een land aanwezig zijn. Zoals in hoofdstuk 2 aan de orde kwam is voor het verzamelen van bloedmonsters een bepaalde infrastruc. tuur nodig. Er zijn laboratorid nodig die beschikken over een koude keten van vriezers, koekasten, een noodvoorziening in het geval van elektrische storingen en verpakkingsmaterialen voor de bloedmonsters. De WHO is bereid om zo'n infrastructuur op te bouwen, maar in de eerste fase van de ontwikkeling van de registratie worden landen geselecteerd waar die voorzieningen reeds op een bepaald niveau zịn zodat direct kan worden begonnen met de rekrutering van vrijwilligers en het afnemen van bloedmonsters. Verderop in dit hoofdstuk zal blijken dat het wiet alleen gaat om de voorzieningen, maar ook om cohorten van mensen met een groot risico met HiV geinfecteerd te raken die all enige tijd zijn gevolgd om de HV-incidentie in een land te bepalen.

De aanwezigheid van goede faciliteiten in de primaire laboratoria is voor het WHO-nelwerk zo belangrijk dat de politieke internationale verhoudingen tussen de WHO en de lidstaten op de tweede plaats komen te staan. Bij de selectie van de landen is eerst gelet op de vaorzieningen van de laboratoria en pas in de tweede plaats op de bereidheid van een land om mee te werken aan zo'n project.

"The choice of Uganda to collaborate in the WHO sponsored AIDS vacine rexwarch and develowment program in 1997 was based on several criteria inclu. ding the arailability of a functioning virology laboratory at UVRI and relatively high prevalance in general population. Additionally, the enabling goverument open policy towards aids control and prevention has made it passible for operational research questions to be investigated".147

Voor de registratie van de diversiteit van HIV selecteent de WHO landen waar in het kader van toekomstige vaccinstudies, incidentiestudies zin uitgevoerd. Dat besluit dient een dubbel doel. Ten eerste kan nu voor de registratie gebruik worden gemaakt van de voorzieningen om bloedmonsters te verzamelen, te testen en te bewaren die voor de HIV-incidentiestudies zijn opgebouwd." Ta Ten tweede kunnen de gegevens die over de diversiteit van HIV worden verzameld van nut zijn in de voorbereidingen van de vaccinstudies. $149 \mathrm{Op}$ deze manier kan de werkgroep zich baseren op bepaalde zekerheden en word: werk bespaard. De praktische arwegingen die de werkgroep makt bij de selectie van de landen, betekent wel dat andere landen worden geselecteerd dan oorspronkelijk de bedoeling was. Bil de selectie van de landen zou bijvoorbeeld worden gelet op de geograw fische spreiding van de geselecteerde landen. Twee van de vier landen die uiteindelijk worden geselecteerd, zijn buurlanden.

Bovendien wordt de epidemie op deze manier op een kunstmatige manier werdeeld in landen. De HIV-registratie wordt opgezet in het kader van de internationale bestriliding van de aids-epidemie. Epidemieën zijn per definitie internationaal ondat virussen en bacterièn zich niet door nationale grenzen laten 
tegenhouden. Om die reden heeft de WHO de bestrijding van infertieziekten ooit als eerste ter hand genomen; de bestrijding van epidemieen maakte het belang van internationaal beleid duidelik (zie hoofdstuk 1). Voor de registratie wordt de diversiteit van HW echter wel per land in kaart gebracht Omdat de landen niet op geografische en epidemiologische criteria worden geselecteerd, zoals oarspronkelijk was bedoeld, kunnen twee wan de geselecteerde landen buurlanden zijn, namelijk Deganda en Ruanda. Desalniettemin worden in de registratie Ruanda en Oeganda als twee aparte gebieden c.q. epidemieèn beschouwd. Later, als de gegevens zijn verzameld en geanalyseerd, zullen de landen wel weer met elkaar in verband worden gebracht, maar op een andere manier. Van elk land wordt de viruspopulatie in kaart gebracht. Als blijkt dat in twee landen dezelfde typen virussen voorkomen, wordt naar een verklaring gezocht. Een verklaring kan de ligging van de landen ten opzichte wan elkaar zijn, maar er wor. den ook andere verklaringen mogelijk, In het proces van registreren transformeren de verhoudingen tussen landen: de buurlanden worden van elkaar gescheiden om later wellicht op andere manieren en met andere landen weer in verband te worden gebracht.

\section{De rekrutering van vrij|willigers}

Na de selectie van de landen is de volgende stap in het proces van registreren de rekrutering van personen die met HIV besmet zijin en die bereid zijn om aan het onderzaek mee te doen. Elk van de primaire laboratoria wordt gevragd in totaal zestig wrijwilligers te selecteren uit alle risicogroepen, in alle klinische sta* dia van de ziekte aids, uit de stad en van het platteland en ten slotte uit alle etnische groepen. ${ }^{150}$ Net als bij de selectie van landen zijn de criteria voor de selectie van de viijwilligers gebaseerd op epidemiologische categorieën.

Om de diversiteit van HIV in kaart te brengen, wordt bloed afgenomen van mensen die met HIV zijn besmet. Bloedmonsters zijn mobieler dan mensen. Voor de vrijwilligers wan het onderzoek zou het onmogelijk zijn on langs de secundaire laboratoria te reizen en zich daar te laten onderzoeken. Bovendien zijn wrijwilligers niet stabiel, ze weranderen te veel om als registratiemateriaal te dienen (de vrijwilligers kunnen ziek worden en het virus in hun bloed kan muteren). Het is veel eenvoudiger om bij hen bloed af te nemen en dat naar de secundaire labo. ratoria te sturen. 151

Een voordeel wanneer de vrijwilligers zelf als onderzoeksmateriaal naar de secun* daire laboratoria zouden reizen is de onverbrekelijke band tussen bloed en persoon. Door alleen bloed naar de secundaire laboratoria te sturen wordt die band werbroken. ${ }^{152}$ De vrijwilligers gaan na de bloedafname weer naar huis terwijl hun bloedmonsters naar een centraal depot in Londen worden gestuurd. Het is dan van belang dat de vrijwilligers en hun bloedmonsters op één of andere manier aan elkaar verbonden blijven. Er ontstaat een probleem als de secundaire laboratoria niet weten van wie het bloed is en daarmee de resultaten wan hum onderzoek los komen te staan van het individu dat onderzocht is. De verbinding tus. sen de vrijwilliger en het bloed die na de bloeddonatie is verbroken, moet op andere manieren worden behouden en verstevigd. 
Een geilkte methode is om een verbinding op papier te creèren. Een formulier dat door de WHO is ontwikkeld en door de primaire laboratoria voor alle wrijwilligers wordt ingevuld, vormt de verbinding tussen een vrijwilliger en het bloedmonster. op het formulier staan vragen over geslacht, leeftijd en woonplaats, de wijze waarop de vrijwiliger besmet is geraakt en het stadium van zijn ziekte. Waarom fuist deze gegevens worden verzameld en geen andere, is een goed voorbeeld hoe epidemiologie een stempel drukt op de ontwikkeling wan de registratie. Om inzicht te kriggen in de verspreiding van aids in Afrikaanse landen is het bijvoorbeeld van belang te weten of iemand getrouwd is, omdat vrouwen hun echtgenoot niet willen (en niet kunnen) vragen om met een condoom te viijen. Die vraag, zo blijkt uit antropologisch onderzoek, kan de echtgenoot opvatten als het bewijs dat zijn wrouw vreemd gaat en een reden zijn om haar te verlaten. ${ }^{153}$ De gegevens die over de HIV geinfecteerden worden verzameld, zijn dus weinig specifiek. Voor de pokkenregistratie (zie het eerste hoofdstuk) die vifftig jaar eerder werd opgezet, zijn dezelfde gegevens verzameld. 154 Gegevens over onder andere geslacht, leeftijd en woonplaats zijn kortom standaardgegevens geworden die voor bijna iedere ziekteregistratie worden verzameld. Het formulier wordt met elk bloedmonster meegestuurd naar het depot. Dankzij het formulier is de vrijwilliger in een schriftelijke en gestandaardiseerde vorm aanwezig in het depot, zonder er zelf daadwerkelijk te zijn." 55

Een algemeen probleem bij formulieren is dat ze niet in alle gevallen volledig of juist worden ingevuld. ${ }^{156}$ Veel gegevens worden namelijk niet doar onderzoekers verzameld, maar door de mensen die in een bepaalde praktijk werken, bijvoorbeeld artsen, laboranten of administratieve medewerkers. Het verzamelen van de gegevens is niet hum primaire taak. Bovendien zijn hun werk en de systemen waarmee ze werken vaak niet ingericht op het verzamelen van gege: vens. De WHO heeft tegen die achtergrond het aantal vragen op het formulier woor de primaire laboratoria zo beperkt mogelijk gehouden.

"The sabjed reporting wart provided the minimum essenval information on epidemiological laboratory and clinical features of HIV infection. It is therefore inportam to andsuer all the questions in this chart". 157

Als de werkgroep erin slaagt om de formulieren wolledig te laten irnullen, is er nog een andier probleem met betrekking tot vrijwilligers. Hoe weet men dat de antwoorden die een vijwilliger geeft ook feitelijk kloppen? Soms geeft de vrijwilliger wel antwoorden, maar de onderzoeker wijfelt of die juist zijn. De werkgroep vraagt de primaire laboratoria daarom uitdrukkelijk vrijwilligers te selecteren over wie betrouwbare gegevens kunnen worden verzameld.

"It is imporiant to include individuals from whom reliable transmission information can be oblained for example maternaltpediatric cases or blood transfuston donors/recipients)" 158

Uit de toelichting blijkt dat voor de werkgroep de betrouwbaarheid van de infor. matie te maken heeft met de verwachting over de mate waarin viijwilligers hun afspraken nakomen. Mensen die al geregeld naal het ziekenhuis komen voor 
controles of bijvoorbeeld bloedtransfusies, zijn in de ogen van de werkgroep buttengewoon geschikt voor het onderzoek. $13 \%$

De ingevulde gegevens worden gecontroleerd met de bedoeling on ontbrekende gegevens alsnog bij de primaire laboratoria op te kumnen vragen. De WHO heeft dankzij eerdere programma's goede contacten opgebouwd met de primaire laboratoria en kan daardoor gemakkeliker eventueel ontbrekende gegevens achterhalen dan het depot en de secundaire laboratoria. Er wordt daarom besloten om de formulieren miet naar de centrale database van het LANL te sturen, waar de gegevens van de karakteriseringen zullen worden opgeslagen, maar naar een aparte database die door de WHO wordt beheerd. 150 Om een verbinding tus: sen vrijwilligers en hun bloed te behouden, worden de gegevens over de viijwilliger dus gescheiden van de gegevens die over het bloed worden verzameld. Wia het formulier kumnen de secundaire laboratoria gegevens over de wrijwilligers verkrigen zonder hen ooit te hebben ontmoet. Ook kunnen via het formulier de vrijwilligers weer worden opgespoord, bijwoorbeeld om hen te vragen voor een tweede keer bloed te geven. Vanwege bescherming van privacy staat op het formulier geen naam of adres, maar wel een code. In het logboek, dat door elk primair laboratorium wordt bijgehouden, kan via deze code naam en adres van de vrijwilliger worden achterhaald.

"A special "WHO HIV isolation and characterization" logbook should be kept, showing the person's WHO ID number, collection numbers, name, address and any other identifying information. This information may be required for follow-up, in case additional information is required, or if consecutive blood samples are needed".16i

De verbinding tussen bloedmonsters en vrijwilligers via de code kan net als bij het formulier op verschillende punten worden verbroken waardoor de bloedmonsters hum betekenis verliezen. ${ }^{162}$ Bloedmonsters kunnen uiteraard per ongeluk worden verwisseld. Op basis van uiterlijke verschillen kunnen vrijwilligers gemakkelijk van elkaar worden onderscheiden. Bloedmonsters züjn echter op het oog allemaal identiek. Om verwisseling tussen de bloedmonsters te voorkomen wordt op elk bloedbuisje een sticker geplakt met de code van de donor.

Het is echter niet altijd gemakkelijk om een wrijwilliger die aan een onderzoek meedoet opnieuw op te sporen. Vrijwilligers kunnen verhuizen en laten dan niet altijd een adres achter. of vrijwilligers hebben wel toestemming gegeven voor het onderzoek, maar willen bij nader inzien toch niet verder meewerken. In een advies aan de WHO onderscheidt Bruce Weniger de verschillende risicogroepen van aids naar de mate waarin zij trouw zijin alan onderzoek, ${ }^{63}$ Onderzoek riaar HIV incidentie in Thailand heeft uitgewezen hoe moeilijk het voor onderzoekers is om prostituees voor langere tijd te volgen. Als de vrouwen stoppen met hun werk, gaan ze vaak terug naar hun familie en willen dan uit angst woor discriminatie niets meer te maken hebben met het onderzoek. Als bekend wordt dat zij meedoen aan onderzoek, wordt al snel de conclusie getrokken dat zij zijn besmet met HIV en dat kan grote consequenties hebben voor hun leven. Homoseksuele mannen daarentegen blijken heel geschikt voor epldemiologisch 
onderzoek, omdat zij regelmatig naar het zjekenhuis komen voor controle op geslachtsziekten en daarom gemakkeliker kunnen worden gevolgd.

De vrifwilligers die door de primaine laboratoria gerekruteerd worden voor registratie van de diversitteit van HIV zijn bijna allemaal op de éên of andere manier verbonden met een ziekenhuis. De vifwilligers zijn bijwoorbeeld zwangere vrouwen die regelmatig naar de kliniek komen voor controle, het zijn mensen die bloed geven of mensen die klinieken bezoeken voor de bestrijding van geslachtsziekten. Aan het aantal prostituees dat als vrijwilliger mag worden gerekruteerd, wordt zelfs een duidelike limiet gesteld, vanwege de praktische problemen om deze groep te volgen: 164

Samenvattend: om vrijwilliger en bloedmonster aan ellkaar te verbinden en voor. al om deze verbinding te behouden, worden minder gegevens over de vrijwilligers verzameld dan men zou wensen, worden de gegevens van de vrijwilligers in een aparte database opgeslagen en geanalyseerd en worden andere criteria gehanteerd bij de selectie van vrijwilligers dan die welke in eerste instantie door de technische werkgroep zijn geformuleerd. Vooral dat laatste is van betekenis. Niet alle eisen die de technische werkgroep formuleert voor de HW-registratie blijken verenigbaar en dus worden sommige in een later stadium gecompromitteend om andere doelen van de registratie wel te kunnen realiseren.

In het begin van het registratieproces, zo blikt, speelt de epidemiologie eem belangrijke rol. De registratie bouwt voort op de netwerken van kennis, instrumenten en voorzieningen die al tijdens en voor epidemiologische onderzoek zijn opgebouwd. 165 Zo zijn de criteria die voor de selectie van landen en wrijwilligers zijn opgesteld gebaseerd op epiderniologische categorieën. In het werk om gegevens te produceren, dat wil zeggen om HIV te mobiliseren en te stabiliseren, wordt het onderscheid in epidemiologische categorieën minder belangrijk. Andere, meer praktische criteria worden nu belangrijker, zoals de voorzieningen in een land voor bloedonderzoek of de trouw vam vrijwilligers aan het onderzoek. De voorzieningen die de werkgroep als eis stelt, zijn wel weer voor een deel ontleend aan epidemiologisch onderzoek om de HIV-incidentie te bepalen; ook de betekenis wan 'onderzoekstrouw' is door de epidemiologen ingevuld. Gaande het registratieproces zal de rol van epidemiologische kennis en woorzieningen kleiner worden. het besiluit om de gegevens die over de vrijwilligers zijn verzameld in een aparte database op te slaan, los van de gegevens uit het bloedonderzoek.

\section{.3 Opslag in het depot}

In dit hoofdstuk staat de wraag centraal welk werk wordt werricht bij het registreren van de diversiteit van het HIV. Daarvoor wordt de reis van gegevens naar de eindbestemming in de database gevolgd. Het eerste deel van die reis is in de vorige paragraaf beschreven. Primaire laboratoria hebben vrijwilligers geselecteerd en hen gevraagd bloed af te staan. Deze bloedmonsters zijn stabiel en 
mobiel, vooral in vergelijking met de vrijwilligers zelf. Na de bloeddonatie gaan die naar huis; alleen de bloedmonsters worden bewerkt en opgestwurd. De bloed. monsters gaan niet direct maar de secundaire laboratoria, maar worden eerst opgeslagen in een centraal depot. Wat gebeurt in het depot? Wat voor werk wordt daar verricht? Hoe wordt in het depot de mobiliteit, stabiliteit en combineerbaarheid van de bloedmonsters verder vergroot?

\section{Bloedmonsters onderweg}

De reis van de bloedmonsters naar het depot is niet zonder risico's. De bloedmonsters zijn mobieler dan de vrijwilligers, maar de stabiliteit ervan kan een probleem zijn. Het bloed verliest betekenis wanneer het niet meer verbonden is met diegene die het heeft gegeven. Het is dan miet meer mogelijk om van de gegevens terug te gaan naar de mensen die met HIV geinfecteerd zijn, wat bete. kent dat de gegevens los staan van de werkelijkheid. Verder kan het bloed onderweg beschadigen waardoor het ongeschikt wordt voor verder onderzoek. Zoals in het tweede hoofdstuk is beschreven heeft de WHO een infrastructuul opgezet voor een snel transport van het bloed onder zo optimaal mogelijke omstandigheden. Toch gaat er regelmatig iets mis. Zo bevriest een deel van de Ruandese bloedmonsters onderweg en duurt de reis van een aantal Thaise bloedmonsters, vanwege een verkeerde adressering, zo lang dat het bloed onbruikbaar is geworden. ${ }^{167}$ Ondanks dergelijke problemen is de technische werkgroep tevreden over het transport en de kwaliteit van de bloedmonsters. Het overgrote deel wan de bloedmonsters is goed verpakt, arriveert binnen de afgesproken tijd bij het depot en voldoet aan de gestelde eisen.

Voor de technische werkgroep is dit depot in de eerste plaats een distributiecentrum waar vandaan de bloedmonsters naar de secundaire laboratoria worden gestuurd voor de karakterisering van HIV. ${ }^{168}$ In die functieomschrijving blijft echter een belangrijk kenmerk van het depot onderbelicht. In het depot worden de bloedmonsters uit de verschillende landen voor het eerst bij elkaar gebracht. Hier worden partijen monsters samengesteld en deze verschillende combinaties worden naar de secundaire laboratoria gestuurd. 169 Het depot vormt dus een fase in het registratieproces, maar de activiteiten op het depot kunnen ook wor den gezien als een registratie op zich. Wat gebeurt er nu precies in het depot met het bloed?

\section{Bloedproducten in vervaardiging}

Zodra de bloedmonsters in het depot arriveren worden zij gesplitst in serum. plasma en bloedcellen. Van de PBMC cellen wordt vervolgens een kweek gemaakt om het virus te isoleren. Door de cellen tot een afweerreactie aan te zetten, wordt het virus geactiveerd. Als bewezen is dat het wirus zich repliceert (vermenigvuldigt), is de virusisolatie geslaagd. 170 Het is niet gemakkelijk om HIV uit bloed te isoleren. Van tevoren wordt verwacht dat de helft van de pogingen om HV te isoleren zal mislukken en daarom zijn de primaire laboratoria gevraagd om twee keer zo veel bloedmonsters te verzamelen dan strikt gesproken nodig is. 171 
"If wirul isolation is done upon 60 samples initially, at least 30 specimens should yield positioe cultures",

In de praktilk blifken echter nog meer isolatiepogingen te mislukken dan is voorzien. Slechts eén op de drie pogingen slaagt. 173

om de kans op succeswolle virusisolatie te vergroten, wordt het selectiecriterium voor de rekrutering van donoren bijgesteld. De primaire laboratoria wordt gevaagd on alleen wriwilligers te selecteren die minder dan twee jaar met HIV besmet zijn. Uit hun bloed kumnen virussen met meer succes worden geisoleerd.174 Er bestaat geen eenvoudige test om de besmettingsduur te bepalen. Met een aids-test kan worclen vastgesteld of iemand besmet is met HIV, mar niet hoelang iemand al besmet is. De dutur van de besmetting kan ook niet worden bepald aan de hand van de symptomen die iemand heeft, omdat de ziekte heel verschillend kan verlopen. Sommige mensen worden al snel na een HW besmetting ziek, terwijl bij anderen de incubatietijd jaren kan duren. Bovendien begint bij de ene aids-patiënt de ziekte met diarree, bij een ander is een bijzondere vorm van huidkanker het eerste symptoom. De enige manier om de besmettingsduur te bepalen is om mensen al regelmatig te testen nog voordat zij besmet zijn, opdat de eerste positieve test het meetpunt is om de duur van de besmetting te bepalen. ${ }^{75}$ Voor HIV-incidentiestudies, die de WHO heeft opgezet in de landen waar vaccinstudies zijn gepland, wordt een groep mensen die het risico loopt met HIV besmet te raken, maar dat nog niet is, een aantal jaren gevolgd en regelmatig getest. Het percentage mensen uit het cohort dat aan het eind van de studie besmet is geraakt, is een maat voor de HIV-incidentie. Van deze mensen is de eerste positieve testuitslag precies bekend en voor hen kan derhalve de besmettingsduur worden bepaald. Zonder de epidemiologische incidentiestudies is de selectie van vrijwilligers van wie de besmettingduur bekend is en van wie men daarom weet of uit het bloed virussen geisoleerd kunnen worden, niet mogelijk. Om mensen te kunnen selecteren van wie de besmettingsduur bekend is, selecteren de primaire laboratoria dus mensen die hebben meegedaan an de HIV-incidentiestudies. ${ }^{170}$

Als virusisolatie slaagt en de monsters zijn bewerkt, is het bloed getransformeerd in 85 bloedproducten:

" $8 \times 0.5 \mathrm{ml}$ of serum

$8 \times 1.8 \mathrm{ml}$ of diluted plasma

$4 \times 5.000 .000$ PBMC, frozen wiable cells

$5 \times 5.000 .000$ cells from cocultures, frozen viable cells

$10 \times 1 \mathrm{ml}$ of virus stock

$50 \times 1 \mathrm{ml}$ of expanded wirus stock

total: 85 vials/patient (minimum)". 177

Deze 85 producten kunnen over de secundaire laboratoria worden verdeeld, waardoor een zelfde bloedmonster tegelijkertijd in Londen, Stockholm. Atlanta en Amsterdam kan worden onderzocht en de secundaine laboratoria dus niet op elkaar hoeven te wachten. Dit uitsplitsen van het bloed in zoveel verschillende delen, draagt ook bij aan een oplossing van het probleem dat primaire laboratoria niet te veel bloed willen afnemen. Hoe meer bloed bij een afname nodig 
is, des te moeliiker is het om donoren te selecteren. Het Oegandese laboratorium heeft om vrijwilligers niet af te schrikken al bestoten on het bloed niet in een bloedzak maar in kleine butsjes op te vangen. Het depot stelt vifttig mililiter bloed als minimum. Bloedmonsters van minder dan wiftig milliliter zijn volgens het depot te klein om over de secundaire laboratoria te worden verdeeld. Vijftig milliliter bloed is miet weel als het over een groot deel van de wereld moet worden verspreid, maar dankzij de bewerkingen van het bloed kan dat wel. De bewerkingen in het depot hebben kortom de mobiliteit van het bloed vergroot., 73

\section{Het belang van een voorraad}

Er is mu voldoende materiaal voor de secundaire laboratoria en het is zelfs moge. lijk om bloedproducten in voorraad te houden.

"It is understood that some materials zoll be set asta as part of a pemanemt collection of the repository. These will indude wo vials, each of seram, plasma, primary PBMC expanded cells and virus stock from each specimen"."

Wat is het belang van zo'n voorraad? Het bewaren van HIV heeft lets vreemds want HIV kenmerkt zich doordat het voortdurend muteert. In het depot wordt echter alles gedaan om het virus niet te laten veranderen. Het virus wordt dus kunstmatig stabiel gehouden. Het depot en met mame de vooraad bloedpro. ducten, is namelijk een belangrijke schakel tussen de wereld die in kaart wordt gebracht en de gegevens in de database. Dankzij de voorraad bloedproducten in het depot is het mogelijk am van de resultaten van de experimenten weer terug te gaan naar het bloed van de patienten.180 Mocht bijvoorbeeld aar de resultaten van de karakterisering worden getwijfeld, dan kan het depot de aanwezige componenten van bloedmonsters opnieuw laten onderzoeken. De winst van het depot is dat heen en weer kan worden bewogen tussem het bloed van HIV-geïfecteerden en de resultaten van laboratoriumexperimenten zonder extra vervorming, aantasting en verval.

Een ander belangrijk voordeel van opslag wan bloedmonsters in het depot is de mogelijkheid tot combineren. Als de bloedmonsters eenmaal in thet depot zijh ondergebracht, kumnen bloedmonsters uit Deganda worden vergeleken met bloedmonsters uit Thailand. Alles wat men daarvoor hoeft te doen is bij wijze van spreken twee laden opentrekken. Zo kunnen de bloedmonsters, als wormden ze een pak kaarten, worden geschud en op verschillende manieren worden gecombineerd. 181 Voor elk secundair laboratorium worden aparte combinaties van bloedmonsters samen gesteld. Het ene laboratorium krijgt tien monsters serum, het andere veertig viruskweken en weer een ander een aantal plasma. monsters gecombineerd met andere onderdelen van het bloed.

Het depot vergroot niet alleen de mobiliteit en stabiliteit van de bloedmonsters. maar ook de mogelijkheden om de bloedmonsters op verschillende manieren naast elkaar te leggen en te vergelijken. Het proces van mobiliseren, stabiliseren én combineren wordt nog verder verfind wanneer de bloedmonsters in de secundaire laboratoria nader warden gekarakteriseerd en de resultaten daarvan op papier worden gezet. ${ }^{82}$ Hoe mobieler en stabieler het object van registratie 
wordt des te verder kunnen de gegevens reizen. Hoe meer gegevens bil elkaar kunnen worden gebracht des te meer combinaties kunnen worden gemaakt en des te harder kumen uitspraken op basis van die gegevens worden onderbouwd:

\section{.4 Langs de secundaire laboratoria}

In de volgende fase van het registratieproces, de karakterisering van de bloedproducten door de secundaire laboratoria, vindt een belangrifke omslag plaats. Zoals eerder is aangegeven bouwt de registratie in de eerste fase voort op epidemiologisch onderzoek. Het criterium voor de selectie wan de landen was geba. seerd op epidemiologische categorieèn. De landen worden uiteindelijk niet volgens dit criterium geselecteen, maar het zijn wel de voorzieningen voor epidemiologisch onderzoek naar de incidentie van HIV die de doorslag geven voor de uiteindelijke keuze van de landen. In de secundaire laboratoria, waar de karakterisering van het bloed plaatsvindt en de gegevens in de database wor den ingevoerd, krijgt de infrastructuur die binnen de moleculaire biologie is opgebouwd voor cle registratie van viraal DNA of RNA, een steeds belangrijkere plaats. In de ontwikkeling wan registraties heeft de moleculaire biologie (zie hoofdstuk 2) een voorsprong op de andere disciplines die samen met de moleculaire bio. logie HIV karakteriseren. 183 Deze voorsprong, en daamee de toenemend dominante positie van de moleculaire biologie, heeft voor de verdere ontwikkeling van de registratie verstrekkende consequenties. Deze treffen met name de verhouding tussen de genetische en de antigene diversiteit van HIV.

\section{De Stuurgroep voor Vaccinontwikkeling}

Het doel van de HIV-registratie is om de genetische én de antigene diversiteit van HIV in kaart te brengen. Aan die doelstelling mag van de technische werkgroep op geen enkele manier worden getornd. Dit wordt duidelijk wanneer de Stuurgroep voor Vaccinontwikkeling, aan wie de plannen voor de opzet van de registratie worden voorgelegd, in eerste instantie alleen de experimenten die de genetische diversiteit van HIV in kaart brengen wil vergoedem.

"The Stering Committee fol the need to use the limited wHO resources for those aspects of the HV chanacterization effort that would bo most critical for accine development, in particular, obtaining sequence information of the enveLope and V3 dowain of the representative HIV-7 strains" 184

De Stuurgroep voor Vaccinontwikkeling beschouwt kennis over de volgorde van de nucleotiden in het virale RNA als essentieel voor de ontwikkeling van het vaccim. De stuurgroep wijst één deel van het RNA aan als het belangrijkste, namelijk het stukje RNA dat genetische informatie bevat over de opbouw van de eiwitmantel en nog specifieker dat deel van de eiwitmantel waar aan antilichamen HIV herkenmen. De stuurgroep erkent wel het belang van de antigene kenmerken van HIV voor de ontwikkeling van het vaccin. De selectie van het deel van de sequentie dat informatie bevat over de antigenen op de eiwitmantel, kan 
worden beschouwd als een compromis tussen de interesses van de moleculail biologen in de sequentie en die van de immunologen in de antigene aspecten van het wirus. Tegelijkertijd stelt de stuurgroep duidelijk prioriteiten. De stuurgroep gaat er van uit dat kennis over de structuur van de eiwitmantel het best kan worden verkregen door onderzoek naar het RNA. Om de eiwitmantel van HIV the onderzoeken, wil de stuurgroep op de eerste plats de volgorde van de nucleotiden op bepaalde plaatsen in het RNA in kaart brengen. 185

De technische werkgroep is thet niet eens met de prioriteiten die de stuurgroep stelt voor de karakterisering van HIV. Het besluit van de stwurgroep ondergraaft volgens hen de kracht van hun woorstel. De HW-registratie die de technische werkgroep voor ogen heeft onderscheidt zich valn andere registraties omdat ze een compleet beeld geett van de genetische, biologische en immunologische kenmerken van HIV. In vergelijking met deze registratie geven andere HIV-registraties, aldus de technische werkgroep, slechts, een fragmentarisch beeld van de diversiteit van HIV.

"Members of the technical asorking group expressed the vien that the main strength of the proposed characterizatione effort acas in its comprehensive evaluation of genetic, biologic and immunologic characteristics of HIV isolates (...). Unless the integrity of the approach was maintained, this effort offerd few adrantages over previous fragmentary efforts". 186

Om het conflict over het belang van de verschillende experimentem voor de karak. terisering van HIV op te lossen, stelt de technische werkgroep voor twee subgroepen op te richten, een genetische werkgroep en een biologisch / immunologische werkgraep. Beide krijgen de taak een voorstel te ontwikkelen voor de karakterisering van HIV. ln het voorstel dient te worden uiteengezet welke experimenten de subgroep wil uitvoeren, wat het belang van deze experimenten is en tegen welke kosten ze kunnen worden uitgevoerd.187 op deze manier kan, dat is althans de bedoeling, elk laboratorium op gelijke voet meedingen om voor de HIV-registratie virussen te karakteriseren.

De twee subgroepen zijn echter niet gelijkwaardig aan elkaar. Zo vertegenwoordigt de genetische werkgroep een veel homogenere groep laboratorla dan de biologisch / immunologische werkgroep. Dat blitkt al uit de discussie over de naam wan de biologisch / immunologische werkgroep. Er wordt gezocht naar een noemer waaronder alle experimenten geschaard kunnen worden. Die gezamenlijke noemer windt men ten slotte in de naam sero-virologische karakterisering.

"It was dectded that vines expansion and characterization, biological charac" terization, serological analysis and neutralization be consolidated under one joint propasal entilled" "Sero-virological Characterization" (...)".18B

Deze met zoveel zorg gekozen naam van de werkgroep wordt echiter weer sinet vergeten want in de dacumenten van de technische werkgroep krijgt de subgroep woortdurend andere namen: "biologic/immunologic subgroup", "sero" virological characterization", "virology / immunology graup" en de "working group on serological screening, immunotypirng and phenotyping". 
Terwill men het in de serowirologische werkgroep nauweliks eens kan worden over een gemeenschappelike noemer voor al het werk, bestaat binnen de genetische werkgroep van meet af aan grote consensus.

"The approach to genetic characterization of HW-1 isolates that had been developed in Geneva as reffirmed. The current concept that HIV isolates fall into at least five nearly equidistant genetic subtypes prowdes a coherent focus for our effortis: 189

Hel gezamenlijke uitgangspunt voor de genetische werkgroep is de classificatie vain HIV in genotypen. Deze classificatie van gemotypen is ontwikkeld door het LANL op basis van de onderlinge vergelijking van gegevens over RNA vain HIV die sinds 1986 in een database van het LANL zijn opgeslagen. Het resultaat van deze analyses is een indeling in vijf genotypen: $A, B_{v} C_{x} D$ en $E_{\text {. In }}$ de tijd dat de plannen voor het WHO-netwerk worden gemaakt en voor de registratie de eerste virussen worden gekarakteriseerd, is het LANL bezig om dit onderscheid in genotypen op te waarderen tot een internationale HIV-classificatie. 190

Het conflict over een prioritering in de experimenten wordt opgelost door twee subgroepen op te richten. Het is een oplossing die analoog is aan eerdere manieren van conflicthantering door de werkgroep. Zo werden ook conflictueuze onderwerpen op vergaderingen nevengeschikt door het opstellen van de agenda. De inrichting van twee afzonderlijke werkgroepen die ieder afzonderlijke voorstellen schrijven voor de genetische en de serologische karakterisering, gaat voorbij aan verschillen in ervaring met registreren bij de betrokken disciplines. Binnen de moleculaire biologie heeft de ontwikkeling van registraties een hoge vlucht genomen, zeker in vergelijking met andere disciptines (zie hoofdstuk 2). Aangezien de HIV-registratie van de WHO voortbouwt op de netwerken die binnen de moleculailre biologie reeds voor de registratie van de RNA-keten zijn opgebouwd, gaat de moleculaire biologie eem almaar zwaardere stempel drukken op de ontwikkeling van de registratie. ${ }^{19 /}$ Andere perspectieven verdwiinen naar de achtergrond.

\section{De karakterisering van HIV}

Bij de karakterisering wan de eerste bloedmonsters komen de verschillen in ervaring die de laboratoria hebben met registreren meteen naar voren. In de evaluatie van de verschillende methoden die zijn gebruikt om HIW te karakteriseren, werken deze verschillen verder door.

Volgens thet plan van de technische werkgroep zal de karakterisering van HIV bestaan uit vier typen experimenten: genetische analysen, serologische analysen, neutralisatie-experimenten en biologische karakteriseringen. Bij een genetische analyse wordt het virale RNA onderzocht door van bepaalde genen de volgorde van de nucleotiden te bepalen. Een serologische analyse heeft tot doel om de antilichamen in het bloed van HIV-geinfecteerden te onderzoeken. Daarvoor zijn eiwitten gesynthetiseerd met dezelfde structuur als de eiwitrantel van reeds geïdentificeerde HIV-virussen en wordt onderzocht welke antilichamen aan welke eiwitten binden. Het eiwit waaraan een antilichaam bindt, bepaalt het 
serotype van het bloedmonster. In neutralisatie-experimenten wordt ook de reactie van antilichamen onderzocht, maar op een andere manier en met een ander doel. Voor de neutralisatie experimenten zijn zogenaamde serapanels ontwikkeld, dat zin verzamelingen van sera (bloedplasma met antilichamen). Onderzocht wordt hoe de verschillende sera reageren op de uit een bloedmonster geïsoleerde virussen. Het gaat bij deze experimenten vooral om de kracht of de intensiteit van de afweerreactie door de antilichamen. Een biologische karakterisering tot slot richt zich op de replicatie wan het wirus en de effecten daarvan op de bloedcellen. Er zijn virussen die snel repliceren en daarbij de gastcel kapot maken en virussen die langzamer repliceren zonder dat zij de cel beschadigen. Uiteindelijk is het doel van de uiteenlopende karakteriseringen om de verschillende eigenschappen van HIV met elkaar in verband te brengen:

"Correlation of genetic, immunologic, and biologic properties of $H / \gamma^{\prime} \rightarrow$ isold-

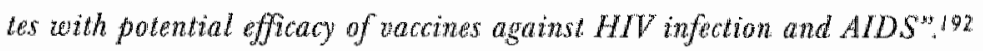

In deze paragraaf worden twee van de vier typen experimenten besproken: de genetische analyse en de serologische analyse.

Voor onderzoek van de genetische structuur van HW zijn verschillende experimenten ontwikkeld. Het ontleden van het genetisch materiaal kost over het alge. meen veel tijd en dat maakt zulke experimenten minder geschikt voor de registratie van de diversiteit wereldwijd, omdat slechts een beperkt aantal virussen op deze manier kan worden onderzocht. Om die reden zijin screeningstechnie. ken ontwikkeld, waarmee op een eenvoudigere en snellere manier het genotype van een virus kan worden bepaald. De technische werkgroep wil de verschillende screeningstechnieken evalueren, met als doel aan het einde van de pilotstudy te bepalen welke methode het beste voor de karakterisering van HIV kan worden gebruikt. Eén van de doelstelling van de pilot is:

"to conduct comparatio waluation of the existing aboratory techiques of HWV genetic screening that may be suilablo for moleculax aptemiology studtes and for large-scale wonitoring of the prevalence and distribution of differant genetic sublypes of HIV in differeste populations grouts and gengraphical locations 193

Daarvoor worden drie methoden naast ellkaar gezet. Het gaat om de PCR gag typing methode (PCR gag), de RNAse Mismatch (RAMM) methode en cle heteroduplex mobility assay (HMA). Alle bloedmonsters uit het depot worden met de drie methoden getypeerd en vervolgens worden de resultaten in een tabel gezet en vergeleken (zie figuur 3).

Doel van de evaluatie is om de beste screeningsmethode te selecteren. Het beste is de methode die de meeste bloedmonsters indeelt bij het juiste genatype. Wat het juiste genotype is, en of er sowieso onderscheid kan worden gemaakt in genotypen, staat echter nog niet wast. Het onderzoek naar de volgorde van nucleotiden in het virale RNA en de classificatie in genotypen zijn nog in ontwikkeling. 194 Van een klein aantal bloedmonsters is een deel wan de volgorde van de 
Figuur 3: De tabel met de resultaten van de genetische screening van HW wolgens drie methoden:

\begin{tabular}{|c|c|c|c|c|c|}
\hline \multirow{2}{*}{ 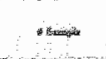 } & \multicolumn{3}{|c|}{ 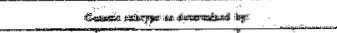 } & \multicolumn{2}{|c|}{ 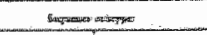 } \\
\hline & mostinges & 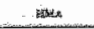 & $\varepsilon=$ & $\operatorname{esc}$ & 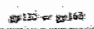 \\
\hline was & & & & 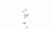 & \\
\hline a thestat & $\Delta$ & i & 8 & E & 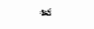 \\
\hline a w with & is & 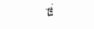 & 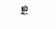 & ॥ & wet \\
\hline 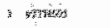 & sprif & $\varepsilon$ & : & a & $\approx$ \\
\hline A sintos & ; & 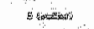 & $\approx$ & $\mathrm{E}$ & : \\
\hline$\therefore m$ & 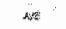 & 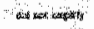 & 田 & 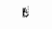 & in \\
\hline$\therefore$ istices & when & ax mastit & a. & : & $\Leftrightarrow$ \\
\hline$=$ mant & 8 & E & s. & E & 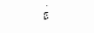 \\
\hline ₹ $\min x$ & is & 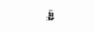 & $"$ & в & " \\
\hline is & whe & 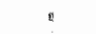 & g & E & is \\
\hline 1: иттиม & suriti & 8 & it & a: & $\infty$ \\
\hline$\therefore$ ythits: & 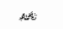 & is & : & 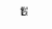 & ex \\
\hline$\therefore$ काmisag & 㱐 & $B$ & - & : & E. \\
\hline in witketil & sixte. & : & : & $\mathrm{F}$ & $x i$ \\
\hline 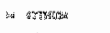 & SE & is & s & $\bar{\Psi}$ & 4 \\
\hline whitia & : & s & : & is & a \\
\hline 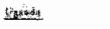 & & & & & \\
\hline 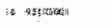 & $n$ & D & $\mathrm{m}$ & is & $\Leftrightarrow$ \\
\hline 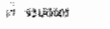 & 活 & 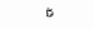 & stel & 8 & 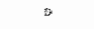 \\
\hline 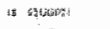 & " & D & si & 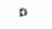 & a. \\
\hline 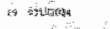 & 6 & 3 & s.tie & b & 0 \\
\hline 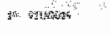 & $"$ & $\therefore$ & exty & $x$ & $\infty$ \\
\hline 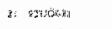 & . &. $\bar{x}$ & and & 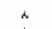 & 2 \\
\hline 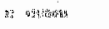 & stit & $\dot{a}$ & tate & is & ث. \\
\hline 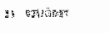 & $*$ & $\star$ & ans & s. & $*$ \\
\hline 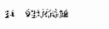 & it & : & by: & 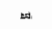 & $\omega$ \\
\hline Iy antopias & i & $\sin$ & 的: & 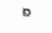 & 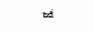 \\
\hline Exisin & & & & & \\
\hline 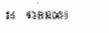 & : & * & zity & : & $\Leftrightarrow$ \\
\hline 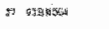 & (xin & s & $\lim _{4}$ & 8 & sa \\
\hline 5. wasistat & $\mathrm{D}$ & " & $3_{1}^{2} 2_{0}$ & s & is: \\
\hline 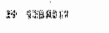 & (5) & * & as & : & w \\
\hline 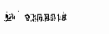 & 0 & $\because$ & $x$ & a & 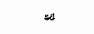 \\
\hline 4: *ithratis & $\mathrm{ma}$ & " & HW: & 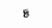 & s4 \\
\hline \& 9 : & 踖 & " & saty & $*$ & 8 \\
\hline 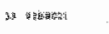 & bos & : & parsa & 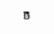 & n \\
\hline 3. *suhws & $\rightarrow$ & is & oid & a & of \\
\hline sti kinhibuse & os & " & na & * & is \\
\hline Fe: $q:$ :PReriss & A & $\infty$ & $\infty$ & wan & $c$ \\
\hline 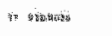 & $x$ & " & w & " & 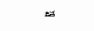 \\
\hline 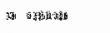 & at & s & ms & $a$ & 世 \\
\hline 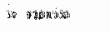 & 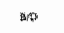 & a & wit? & 尚 & 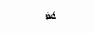 \\
\hline ingadites & & & & & \\
\hline 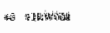 & n & i & aith & i. & $s$ \\
\hline 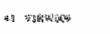 & $n$ & s & 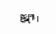 & $A$ & 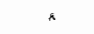 \\
\hline 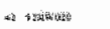 & * & 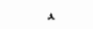 & ails & i & * \\
\hline 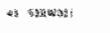 & * & k & का & a & $\Delta$ \\
\hline 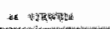 & \& & s & .t. & is & wa: \\
\hline
\end{tabular}

$-22$

Bron:WHO/GPANCU (1994), Report of the technical meeting of principal invegtigators of the WHO netwrork for the HW isolntion and chartacterization, $6-8$ september, Geneve.

nucleotiden reeds geanalyseerd en de resultaten van de drie screeningsmethoden kunnen daarmee worden vergeleken. De meeste bloedmonsters zijn echter niet op andere manieren getypeerd omdat het bepalen van de volgorde vam de nucleotiden eenvoudigweg te veel tijd kast. De screeningsmethoden zijn ook ontwikkeld om op een snellere en goedkopere manier het genotype wan virus- 
sen te bepalen. Van de meeste bloedmonsters is dus alleen bekend wat de resul taten van de drie screeningsmethoden zijn. Op basis van de ondertinge vergelifking van de resultaten van de typering volgens de drie methoden moet wor. den bepaald wat de beste methode is.

Bij de vergelijking van de drie methoden komen een aamtal verschillen in de categorisering van de bloedmonsters naar voren. Een deel van de verschillen in de uitslag van de tests vollgt een vast patroon. De PCR-gag-methode wijkt bijvoorbeeld consequent af van de HMA- en de RAMM-methode. Terwijl de HMAen RAMM-methode de bloedmonsters het type E geven, geeft de PCR-gag-methode de bloedmonsters twee typeringen: $A$ en $E$ (zie figuur 3 ). Niet bil alle bloedmonsters blijken de verschillen tussen de typerngen echter steeds consistent. Het bloedmonster 92 UG038 heeft biivoorbeeld volgens de PCR-gag-methode het genotype B, volgens de HMA-methode het genotype D en volgens de RAMMmethode het genotype $D$ of $E$. Het word dan lastig om de verschillen in de resultaten van de methoden te beoordelen.

Toch wordt de HMA-methode als de beste geselecteerd. De HMA-methode geeft - in vergelijking met de andere twee methoden - minder vaak als enige een afwijkende typering. Het is dus niet zo dat de HMA-methode in alle gevallen de juiste typering geeft (wat de juiste typering is, is immers onbekend), maar de HMAmethode geeft een typering die het meest overeenkomt met de typeringen van de andere methoden.

De selectie van de HMA-methode als de beste betekent dan ook niet dat de andere twee methoden daarmee afvallen. Dat laatste was wel het doel van de evaluatie, namelijk de selectie van de beste methode. Na de vaststelling dat de HMA-methode in de typering het meest consistent is, blijven de RAMM-methode en de PCR-gag-methode in gebruik.

Dat de experimenten naast elkaar kunnen worden gebruikt, is het resultaat van veranderingen in het netwerk waar de experimenten onderdeel van uitmaken. Zonder een herschikking van de experimenten ten opzichte van elkaar, zouden de resultaten ellkaar soms tegenspreken of is er sprake wan dubbel werk. Gaandeweg de evaluatie veranderen echter de relaties tussen de experimenten. Hoe worden de experimenten herschikt? Als eenmal de HMA-methode als de beste screeningstechniek is geselecteerd, worden de verschillen in de testuit. slagen minder belangrijk en gaan juist de overeenkomsten tellen. Het onderscheid dat de HMA-methode maakt tussen de genotypen van HIV, wordt krachtiger wanneer de andere methoden tot dezelfde resultaten komen.

"the PCR-gag fingerprint method allowes comparable results with the HMA to be oblained".195

De HMA-methode bepalt welk bloedmonster tot welk genotype behoort. De andere methaden worden op die methode aangepast en kunnen vervolgens de uitslag van de HMA-methode anderbouwen. 190

"the RNAse A mismatch method needs further improvement by using newly identified reference strains/standards".197 
De RAWM-en PCR-gagmethoden, die eerst de concurrenteh van de HMA-methode zün, worden nu bondgenoten van de HMA-methode en samen maken de drie methoden het onderscheid in genotype sterk. Om genotypen te onderscheiden blikt ëèn methode niet voldoende; er ziln verschillende methoden nodig die samen, nadat zij zorgvuldig op elkar zijn afgestemd, de meetresultaten hard maken.

Het onderscheid in genotypen wordt als het eenmal hard is gemaakt, de basis voor de evaluatie van de andere karakteriseringsmethoden. Voor de serotypering zin verschillende eiwitpanels ontwikkeld waarmee de reactie van antilichamen kan worden getest. Van die eiwitpanels heeft de technische werkgroep er twee geselecteerd die onderscheid kunnen maken in genotypen. ${ }^{198}$

Bij de evaluatie van de serotyperingen blijkt het onderscheild in serotypen niet overeen te komen met het onderscheid in genotypen. Daaruit zou geconcludeerd kunnen worden dat de genetische diversiteit de ontwikkeling van een effectief vaccin mogelijk niet in de weg staat. Voor de effectiviteit van een vaccin zijn genetische verschillen alleen van belang voor zoverre die verschillen tot uiting komen in de structuur wan de eiwitmantel want daarop haken de antilichamen die het vaccin opwekt, aan. In plaats van een discussie te woeren over het belang van het onderscheid in genotypen voor de ontwikkeling van een vaccin, besluit de werkgroep echter om - net als bil de drie genetische screeningsmethoden de serologische typeringsmethoden te verbeteren zodat het onderscheid in serotypen zich beter verhoudt tot het onderscheid in genotypen. Het onderscheid in genotypen blift daarmee model staan voor het onderscheid in serotypen.

"The results with Ugandan and Riwandan sera did not show any clear reactivity patterns. In some cases, serwm from an Ugandan subject infected with $D$ sublype virus showed the highest reactioity with a $D$ consensus peptide followed by $A$ consensus peptide, while sera from subjects in Uganda and Rivanda infected with subtype A reated equally well with consensus peptides comesponding to clades $A$ and $C^{*}: 199$

Bij de evaluatle van de serologische typeringsmethoden wordt kortom op dezelfde manier gesleuteld aan de verhoudingen tussen de methoden. 200 voor de evaluatie van de genetische screenimgsmethoden vergelijkt die werkgroep de resultaten van drie methoden onderling, maar de resultaten van de serotypering worden vergeleken met de resultaten van de gehotypering. De serotypen worden gemaakt tot bondgenoten var de genotypen, maar dan wel in een onder. geschikte rol.

Howel het uitdrukkelijk het doel van de registratie is om zowel de genetische als de antigene diversiteit van HIV in kaart te brengen, wordt gaandeweg de antigene diversiteit een afgeleide van de genetische diversiteit. Geen van de karakteriseringsmethoden kan een eenduidig onderscheid maken tussen typen virussen. De experimenten worden echter zo met elkaar verbonden dat zij samen wel een onderscheid kunnen maken. De PCR gag en de RAMM methode worden gebruikt om de resultaten van de HMA methode te ondersteunen. Het onder. 
scheid in genotype word vervolgens model voor het onderscheid in serotypen. De hegemonie van de moleculaine bialogie over immunologie is bevestigd.

\section{.5 De eindbestemming: de database}

Op de reis van primaire naar secundaire laboratoria is de diversiteit van HIV steeds verder in delen ontleed. Dat proces begint met de selectie van de lan* den die als aparte gebieden worden beschouwd. Vervolgens ziin vrijwilligers geselecteerd die bloed hebben gegeven. Hun bloedmonsters zijn naar het centrale depot gestuurd. In het depot is het bloed gesplitst en verwerkt tot uiteemlopende bloedproducten. De bloedproducten zijn naar laboratoria over de hele wereld gestuurd die elk op eigen wijze onderscheid hebben gemaakt in genotypen, serotypen of biologische typen. De laatste stap in het proces van registreren is om de elementen waruit de diversiteit van HIV nu bestaat en die van elkaar zijn losgemaakt, gescheiden, geclassificeerd en benoemd, weer bij elkaar te brengen in de database. ${ }^{201}$

\section{Geen eigen database}

De plaats waar dit gebeurt is een database van het LANL. Het LANL beheert reeds een registratie voor gegevens over de volgorde van de nucleotiden in het RNA van HIV.202 De ontwikkeling van dergelike grootschalige, internationale datan bases is een typisch kenmerk geworden wan moleculair biologisch onderzoek. Dergelijke databases zijn oorspronkelijk opgezet als een alternatieve manier om de resulitaten van moleculair biologisch onderzoek te publiceren. 203 Sinds de jaren zeventig zijn databases in de moleculaire biologie steeds belangrijker geworden voor het onderzoek. ${ }^{204}$ In het kader van het Human Genome Project is veel geinvesteerd in de infrastructuur voor de registratie van gegevens over de opbouw van DNA R RNA.205 De gegevens die in het kader van het Human Genome Project over de volgorde van nucleotiden worden verzameld, worden niet allemaal meer in wetenschappelijke tijdschriften gepubliceerd. Opname in de database telt als het ware als een wetenschappelijke publicatie.

De introductie wan databases hebben volgens Hilgarther echter ook de werhoudingen tussen onderzoekers en de onderzoeksmethoden binnen de moleculaire biologie veranderd.206 De moleculaire biologie heeft zich van een experimente. le wetenschap ontwikkeld in de richting van een meer theoretische. Onderzoekers verlaten de laboratoriumtafel en nemen plaats achter computers waarmee zij met het klikken van de muis grote hoeveelheden gegevens uit de hele wereld op het scherm kunnen krijgen. De ontwikkeling van databases is een typisch fenomeen binnen de moleculaire biologie en heeft voor die discipline belangrike consequenties gehad.

De werkgroep besluit niet zelf een nieuwe database op te richten, maar gebruik te maken van de voorzieningen van het LANL. Voor de technische werkgroep is de keuze van het LANL als de plaats waar alle gegevens zullen worden opgeslagen vooral een praktische keuze. Het LANL heeft reeds een infrastructuur opge- 
Ztet voor het registreren andyseren van gegevens over HV waarvan de WHO gebruik kan maken. Als de WHO zelf geen infrastructuur hoeft op te bouwen voor de registratie van de verzamelde gegevens worden geld en tijd bespaard.

"A computerized data base is clearly essential for the collection, management, and subsequent analysis of the dala generated by the multi-center study survey. To a large extent, the inforstruture for sequence storage and analyses (via computer faciltives at Los Alamos Nalional Laboratory, Los Alamos, New Mexico, USA under the direction of Dr Gerald Myers) is already in place".20

Is de keuze van de database inderdaad alleen maar een puur praktische oplossing voor de registratie van de gegevens waarmee geld en tijd worden bespaard? In hoofdstuk 2 is reeds betoogd dat organisatorische randwoorwalarden verweven raken met inhoudelijke keuzen. De keuze voor het LANL uit organisatorische overwegingen kan consequenties hebben voor de inhoud wan de database.

\section{De vorm van de gegevens}

De database van het LANL is ingericht om de volgorde van nucleotiden te registreren. De database heeft derhalve als grondslag een structuur warin wetenschappers een RNA- of DNA-streng noteren. Dit is een lange reeks van tekens waarbil de volgorde van bijzonder belang is. Deze vorm wordt ook aangehouden voor de database die het LANL ontwikkelt voor het WHO-netwerk. Net als de nucleotiden in het RNA of DNA, worden de gegevens wan de bloedmonsters achter elkaar gezet (zie figuur 4).

Figuur 4: De vorm van de gegevens in de database.

De keten: AAA GGC GGG AAA GUC UUC (...)

De gegevens: HIV1 A92FWOOB WHO (...)

In deze vorm geeft de positie vam het teken in de reeks aan waar een cijfer of letter voor staat, net als in RNA. Op de vijfde positie staat bijwoorbeeld een A voor het genotype en op de 37 -ste positie voor het serotype. Elke positie heeft een betekenis. Het is daarom van essentieel belang dat de volgorde van de gegevens niet in de war raakt. Fouten kumnen ontstaan als bij het invoeren per ongeluk ển gegeven wordt overgeslagen of als een gegeven ontbreekt. Om de invoer van gegevens snel te kunnen controleren is bepaald dat in de reeks cijfers en letters elkaar afwisselen. Ontbrekende gegevens worden vervangen doop een streepie, daarmee wordit voorkomen dat alle daarop volgende gegevens naar links verschuiven. Bovendien wordt de reeks van gegevens zo kort mogelijk gehouden en worden miet alle beschikbare gegevens in de database opgeslagen.

"All sequences included in the WHO study are HWV-7 and WHO, so those characters were deleted to reduce the number of characters". 208

De structuur van de database heeft op verschillende manieren consequenties 
voor de inhoud ervan. Aangezlen de volgorde wan de gegevens belangriljk is en nilet mag worden verstoord, is het niet mogelik om bil een bloedmonster twee genotypen in te wullen: In de tabel waarin de resultaten van de genetische screeningsmethoden naast elkaar zijn gezet, is dat wel mogelijk (2ie paragraaf 4). De opzet van de database sluit twijfel over de juste typering van een bloedmonster uit. Als er twee typen worden aangegeven waarin de bloedmonsters kunnen worden ingedeeld, moet een keuze worden gemaakt. De structuur van de database dwingt daartoe. Op die manier wordt onzekertheid over een juiste type. ring definitief onzichtbaar gemaakt.

"From HMA, the subtype status of la samplef was not clear, was a $C$ or an $F$. From three analysis of reference $C$ and $F$ subtype, we tached the condusion that is best dustered with $C$ sequences". 209

De vorm van de database plaatst de gegevens bovendien in een hiërarchie. Het LANL heeft voor het WHO-netwerk de oorspronkelijke HIV-database uitgebreid om rumte te creèren voor de andere gegevens die over HIV worden verzameld. Aan de keten van gegevens zijn extra posities toegevoegd. De gegevens die extra aan de database worden toegevoegd, komen achter de andere gegevens te staan. Terwijl het genotype op nummer vij staat, krijgt het serotype de 38 ste positie (zie figuur 5 ).

Het eerste deel van de keten (tot nummer 19) is bovendien gestandaardiseerd;

Figuur 5: De volgorde van de gegevens in de database.

1-4. virus (HIV1)

5 genetic subtype

6, 7 year

8,9 country of origin

10.12 sample number

13-15 study source/ responsible laboratory

16-17 isolation number

18-19 clone number

20 region sequenced

21 sequence contact

22 sample source

23 DNA or RINA sample source

24 health stalus

25,26 transmission mode

$27,28 \mathrm{pll:GM/BK}$

29-30 phenogram consensus: GMMMK

31 culture phenotype

32 seroconversion time

33-36 sCD4/gp120 binding inhibition titre

37 serotype 210 
het behoort tot de internationale HW-nomenclatuur. Voor het tweede deel, 20 tot en met 45 met daarin de biologische en de immunologische classificaties, bestaat geen standaard. Vanwege dit verschil kumen alleen de gegevens uit het eerste deel van de "keten" gemakkelijk en betrouwbaar worden uitgewisseld met gegevens uit andere databases. Voor die in het tweede deel geldt dit niet.

"A second identifier, consisting of a limited number of ASCII characters can be appended to the primary dentifier. White this information may oary from laboratory to laboratory, the whily of this metasequences will dopend upon strict adherence wo conventions" 21

\section{Een snelle analyse van de gegevens}

Naast deze met de geschiedenis en structuur van de database verbonden aspecten zijn er nog andere factoren die beperkend werken. Het LANL heeft voor de analyse van gegevens in de database software ontwikkeld. Deze software vaagt snelle computers en vooral bij de primaire laboratoria ontbreken die. In de eerste lase van de registratie zullen de primaire laboratoria zelf geen gegevens analyseren, maar in de toekomst zullen zii dat wel gaan doen - althans dat is de bedoeling. ${ }^{212}$ Bovendien is de programmatuur van het LANL helemaal toegespitst op de analyse van de volgorde van nucleotiden.

Het LANL overweegt om - naast haar eigen programmatuur - het softwareprogramma hypercard te gebruiken om de gegevens van het WHO-netwerk op de slaan. Hypercard is volgens het LANL daarwoor een geschikt programma omdat het toegankelijker is voor de primaire laboratoria dan de eigen programmatuur van het LANL. Voor hypercard zijn geen snelle computers nodig. Hypercard is echter minder geschikt voor statistische analyses.

"For" special projects, including the WHO-network for HIV isolation and characterization, Dr. Myers zeas proposing to create Hypercard reports for Brovesing on Macintosh computers. This would create several problems of which the most imponant would be: 1 lack of compatibility between the primary laboralories Arepositories data-sels, likely to be managed on IBM-compatible computers with sofiware ruming wnder DOS, and the data-set maintained by LANL and 2) lack of or restricted amenability to statistical analysis".213

Op het moment dat binnen het LANL systeem keuzen moeten worden gemaakt is overigens nog niet duidelijk hoe de data van de secundaire laboratoria zijn opgebouwd.

"At present, it is not known what form the data generated by the secondary laboratwies will take; whether, for example, they will be numeric, or recorded as character strings, as are sequences". 214

Het LANL beschouwt de keuze van het juiste softwareprogramma als een orga. nisatorisch probleem (in dit geval de beschikbaarheid wan computers) waarvoor een praktische oplossing wordt gezocht.

"At the wery least, the software adopted should be capable of producing flat ASCIl files, which could then be inerged with similar files from the primary 


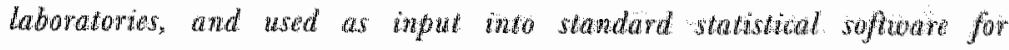

$$
\begin{aligned}
& \text { analyoris"215 }
\end{aligned}
$$

De werkgroep gaat er hierbij vanuit dat zulke beslissingen geen consequenties hebben voor de inhoud van de database, omdat verondersteld wordt dat de structurur van de gegevens er weinig toedoet: de structuur van de gegevens kan te allen tijde worden aangepast. De vorm van de database bepaalt echter in belangrijke mate de structuur van de gegevens en daarmee de wijze waarop de gegevens kunnen worden geanalyseerd.

De eerste analyses van de gegevens voert het LANL uit met haar eigen softwareprogramma's, de programma's van de HIV-sequentiedatabase. Het LANL is van plan om de gegevens op drie manieren te analyseren, twee genetische analyses en één analyse om de volgorde van de nucleotiden in verband te brengen met de biologische en antigene kenmerken van de virussen.

1. The incorporation of nucleotide sequences into phylogenetic trees;

2. the quantification of genetic drift;

3. correlation of changes in nucleotide/protein sequences with biological and antigenic characteristics of HIV strains.216

Wegens tijdgebrek worden echter de eerste twee analyses wel uitgevoerd, maar blijft de derde analyse achterwege. Welke analyses in een korte tijd uilgevoerd kunmen worden, wordt bepaald door de structuur van de database. Gevolg is dat alleen genetische gegevens worden geanalyseerd.

In de database worden de gegevens kortom volgens geheel nieuwe principes bij elkaar gebracht; principes die met name afhankelijk zijin van de ontwikkeling van classificaties in de moleculaire biologie en het instituut waar de gegevens worden apgeslagen. ${ }^{27}$ Hoewel de WHO-registratie wordt apgezet om zowel de genetische als de antigene diversiteit van HIV in kaart te brengen en zich daarmee dus onderscheidt van andere registraties, is het resultaat dat uiteindelijk alle gegevens de vorm krijgen van een RNA-streng en die clan ook als zodanig worden geanalyseerd. In successievelijke stappen wordt vanaf de bloedafname tot de opname van gegevens in het LANl. de madruk op een genetische analyse ver* groot en verdwilnen geleidelijk aan de mogelijkheden woor een immunologische analyse. Beschikbare infrastructuur, aanwezige kennis en standaardisatie van opslag werken samen om dit eindresultaat te produceren.

\section{.6 Slot}

De WHO heeft het initiatief tot de ontwikkeling van de HIV-registratie genomen om langs die weg de ontwikkeling van HIV-vaccins te stimuleren. In de landen waar de WHO vaccinstudies heeft gepland, Ruanda, Oeganda, Thailand en Brazilie, wordt dan als eerste de diversiteit van HIV in kaart gebracht. Voor de ontwikkeling van vaccins zijn niet alleen gegevens over de genetische diversiteit van HIV relevant, maar ook over de antigene diversiteit in verband met de reactie van antilichamen die HIV mogelijk kunnen neutraliseren. Om die reden 
is cle registratie van de WHO breder opgezet dan de meeste andere HM-registraties die vanwege hun oorsprong in de moleculatre biologie uitsluitend gegevens over de genetische diversiteit van HIN verzamelen.

De WHO ontwikkelt de registratie niet zelf, maar schakelt daarvoor wetenschappers in die deskundig zïn in de verschillende benaderingen van de diversiteit van HIV. De onderzoekers maken vervolgens een plan voor de opzet van de registratie en werken mee aan het registreren van de diversiteit van HIV. Daarbij maken zij gebruk van voorzieningen die zij eerder voor hun eigen onderzoek hebben opgebouwd. De primaire laboratoria die de WHO selecteert voor het verzamelen van bloedmonsters hebben bijvoorbeeld al eerder meegedaan aan HW-incidentiestudies en beschikken daarom over kennis en faciliteiten om in het kader van een HIV-registratie bloed af te nemen en te testen. Binnen de moleculaire biologie zijn databases en classificaties ontwikkeld voor de registratie wan virussen waarvan de HIV-registratie van de WHO gebruik maakt. Dat is het geval met de HVV-sequentie database van LANL.

Het gebruik van bestaande voorzieningen en classificaties maakt de HIV-registratie van de WHO tot een succes, dat wil zeggen de mobiliteit, stabiliteit en combineerbaarheid van HIV als een kennisproduct warden er door vergroot. Dankzij de HV-incidentiestudies weten onderzoekers welke risicogroepen voor het onderzoek gemakkelijker te volgen zijn dan andere. Van de mensen die deel hebben genomen aan de incidentiestudies kan de duur van de besmetting worden bepaald, wat weer van belang is voor de kans op een succesvolle isolatie van het virus later in het proces van registreren. De gevestigde praktijk van classificatie in genotypen is ten slotte een belangrijke basis vaor de samenwerking van de laboratoria in de genetische subgroep en later ook voor de hele werkgroep.

Het netwerk voor classificaties, voorzieningen en feiten waarop de HIV-registratie van de WHO voortbouwt, drukt echter wel een stempel op de ontwikkeling van de registratie. Dat bepalt welke gegevens in de registratie terechtkomen en welke er weer uit kunnen worden gehaald. Zo wordt een andere groep vrijwilligers geselecteerd dan oorspronkelijk de bedoeling is. Als criterium was gesteld dat vrijwilligers uit alle risicogroepen, van het platteland en uit de stad en alle etnische groepen moesten worden geselecteerd. Uiteindelijk worden voornamelijk vrijwilligers geselecteerd die op de éen of andere manier verbonden zijn met het ziekenhuis, bijvoorbeeld zwangere wrouwen die op controle komen of mensen die een bloedtransfusie krijgen.

Aan het begin wan het registratieproces drukt de epidemiologie een belangrijke stempel op de registratie, maar dat verandert gedurende het registratieproces. De epidemiologische gegevens die over de vrijwilligers worden verzameld worden zelfs in een aparte database opgeslagen, gescheiden vam de gegevens van de karakteriseringen van HIV. De rol van de moleculaire biologie wordt juist groter. Ook al kan het onderscheid in genotypen dat op basis wan de volgorde van nucleotiden wordt gemaakt, nog niet hard worden gemaakt (de methoden om het genotype van HIV te bepalen geven nog uiteenlopende resultaten) toch wordt het onderscheid in genotypen het model voor het onderscheid in serotypen. Het 
resultaat van de keuze om alle gegevens door het LANL te laten registreran dat de HIV-sequentiedatabase heeft ontwikkeld. is dat gegevens op volgorde worden gezet warbij de genetische gegevens voor de andere gegevens komen te staan. Het gaat daarbij natuurlijk niet alleen om de volgorde van de gegevens op zich, maar deze volgorde is indicatief voor het verschil in standaardisatie en daarmee voor de ultwisselbaarneid van de gegevens en de mogelijkheden tot analyse.

De werkgroep heeft een bredere HIV-registratie willen opzetten dan de reeds. bestaande HIV-registratie door niet alleen de genetische maar ook de antigene diversiteit van HIV in kaart te brengen. Dat de antigene diversiteit gaandewes het proces wan registreren ondergeschikt is geworden aan de genetische diversiteit, is het resultaat van tal van praktische keuzen waarvan de werkgroep de inhoudelike consequenties niet heeft overzien. Beslissingen als de oprichting van twee subgroepen of de keuze voor de LANL-database hebben de inhoud van de registratie voor een belangrijk deel gevormd. Uiteraard is de uitkomst van de vele pragmatische keuzes die de technische werkgroep in het proces van registreren heeft gemaakt, niet toevallig. Voor de registratie van de genetische diversiteit is immers reeds een infrastructuur opgebouwd waarvan de werkgroep gebruik maakt. Als de werkgroep de consequenties van haar keuzes had overzien, had zij wellicht besloten om toch zelf een infrastructuur op te bouwen voor het verzamelen, invoeren en analyseren van de gegevens.

Hel werk dat wordt verricht of waarvan gebruik wordt gemaakt om te kunnen registreren vormt niet alleen de inhoud van de registratie, maar heeft ook consequenties voor het beleid dat de WHO wil ontwikkelen. De registratie van de diversiteit wan HIV is voor de WHO onderdeel van de voorbereiding op vaccinstudies. Aan het begin van het project vermoeden deskundigen dat de diversiteit van FIIV mogelijk een probleem vormt voor de effectiviteit van een vaccin. De WHO wil eerst meer inzicht in de mogelijke consequenties van de genetische diversiteit woor de antigene kenmerken van HIV voordat zij besluit of vaccinstudies verantwoord zijn. Aan het eind van de pilotstudy wordt het steeds moeilijker om de genetische diversiteit niet als probleem te zien voor de ontwikkeling van vaccins. Nu de antigene diversiteit is gevormd naar de genetische diversiteit, is het probleem van de genetische diversiteit verbreed.

De WHO gaat er vanuit dat eerst gegevens worden verzameld en daarma een beslissing wordt genomen over het beleid ten aanzien van vaccinstudies. In het proces van registreren, 20 blijkt uit bovenstaande analyse van dit proces van registreren, wordt zo'n beleidskeuze reeds im hoge mate voorgevormd. 


\section{hoofdstuk 4:}

\section{Transnationale verhoudingen}

\section{De kloof tussen Noord en Zuid in het WHO-netwerk}

\section{.1 Introductie}

De WHO heeft haar HIV-netwerk opgezet met als primair doel gegevens te verzamelen over de diversiteit van HIV. Deze gegevens worden verzameld in het kader van de voorbereiding van vaccinstudies. Dit is echter niet het enige doel. Vila het netwerk wil de WHO ook het gezondheidsonderzoek in ontwikkelingslanden ondersteunen en stimuleren. De infrastructuur van de primaire laboratoria die de WHO helpt opbouwen (zie hoofdstuk 2) past binmen deze beleids. doelstelling. In het kader van de opbouw van een infrastructuur wordt onder andere een koude keten opgezet voor het verzamelen en bewaren van bloedmonsters. In de eerste fase van de ontwikkelling van de registratie - de voorstudie - rekruteren de primaire laboratoria vrijwilligers en nemen zij bloedmonsters af. Vervolgens reizen de bloedmonsters naar een centraal depot in Europa waar ze worden opgeslagen en waar het bloed geschikt wordt gemaakt voor nadere karakterisering. De karakterisering van het virus wordt gedaan in de secundaire laboratoria. Van meet af aan is het de bedoeling van de WHO om de taken wan de primaire laboratoria in het WHO-netwerk in een latere fase uit te breiden. De primaire laboratoria zullen dan zelf bloed gaan bewerken en HIV uit bloed isoleren. Ook is het de bedoeling dat zij dan een eerste karakterisering van de virussen gaan uitvoeren, bijvoorbeeld door de virussen op genotypen te screenen. 218

De aandacht die de WHO heeft voor gezondheidsproblemen in landen in de derde wereld en de steun die deze landen van de WHO krijgen bij de ontwikkeling van een betere gezondheidszorg üs een heikel issue. De WHO, zo luidt kritiek, is vooral gericht op de ontwikkeling van kennis met betrekking tot westerse gezondheidsproblemen.219 De WHO wordt wemeten te weinig aandacht te hebben voor de specifieke problemen waarmee ontwikkelingslanden kampen. 
Wat hebben ontwikkelingslanden aan geavanceerde medische technologie als er niet eens schoon water is, zuigelingenzorg ontbreekt en er onvoldoende eten is? In reactie op deze kritiek gaat de WHO meer aandacht geven aan "Primary Health Care". Er komt een programma dat tot doel heeft om basale gezondheidsvoorzieningen op te zetten.220 Dankzij "Primary Health Care" hebben meer mensen in ontwikkelingslanden toegang gekregen tot de gezondheidszorg. Volgens critici is van de ontwikkeling wan een integrale en emancipatoire gezondheidszorg echter nog weinig terechtgekomen. De kloof tussen westerse gezondheidszorg en de gezondheidszorg van mensen in ontwikkelingslanden is nauweliks verkleind. 221

In voorafgaande hoofdstukken is beschreven hoe in het werk dat wordt verricht bil het opzetten van een registratie en tijdens het registratieproces zelf, de verhouding tussen de genetische en de antigene diversiteit en daarmee de verhouding tussen de secundaire laboratoria onderling is verschoven. De laboratoria die de immunologische en de biologische kenmerken wan HIV onderzaeken zilin een restcategorie geworden. Het zilin laboratoria die nog slechts negatief gedefinieerd zijn als de laboratoria die niet de genetische diversiteit van HIV in kaart brengen. De antigene diversiteit is ondergeschikt geworden aan en is gevormo naar de genetische diversiteit.

Deze verschuiving in de verhouding tussen de genetische en de antigene diversiteit is het onbedoelde resultaat van eem reeks van kewzes die de werkgroep. in het proces van registreren heeft gemaakt. Het was geen uitkomst die bedoeld of voorzien was. Op een soortgelijke wijze wordt in dit hoofdstuk onderzocht hoe in thet proces van registreren de Noord-Zuid verhoudingen in het WHO-netwerk worden gevormd. Daarbij moet in het oog worden gehouden dat de dis. cussie over de relatie tussen WHO en ontwikkelingslanden vooral haar voornaamste brandpunt heeft in de intenties of bedoelingen van de WHO.222 De WHO wordt verweten haar beleid onvoldoende te richten op gezondheidsproblemen in ontwikkelingslanden. Deze nadruk op intenties is naar mijn mening te beperkt. In dit hoofdstuk wil ik laten zien dat de intenties van de WHO weliswar goed kumnen zijn, maar dat de praktijk heel anders kan uitpakken dan oorspromkelijk in de bedoeling lag.

In zijn artikel "De sociologische studie van de transnationale samenleving" brengt De Swaan de ontwikkeling van internationale registraties in verband met de vorming van een transnationale cultuur. ${ }^{223}$ Ten eerste kunnen internationale statis. tieken worden gezien als bronnen die iets zeggen over de internationale relaties door handel en toerisme mar ook doop telefoonverkeer. Ten tweede dragen internationale registraties volgens De Swaan bij aan de wedijver tussen landen om meer te bereiken dan andere landen. Intemationale registraties leveren sleutelbegrippen en basisgegevens voor de vergelijking tussen landen. De Swaan beperkt zijn analyse echter tot de eindproducten van registraties - cijfers en grafieken in rapporten en publicaties - en gaat niet in op het proces van registreren zelf en het effect daarvan op tramsnationale relaties.

Om die lacune op te vullen is het goed om de instrumenten van het hedendaagse wetenschapsonderzoek in te zetten. Daarmee kan worden geanalyseerd 
hoe de ontwikkeling van kennis en techniek is werweven met de vorming van sociale verhoudingen. Een belangrilk woorbeeld voor de andyse die in dit hoofd. stuk wordt gegeven van de opbouw van een transnationaa! wetenschappelik netwerk is de studie van $O^{\prime}$ Connel, die heeft laten zien hoe een universele eenheid als de wolt kan worden gezien als het resultaat wan wereldwijde samenwerking tussen laboratoria. $2240^{\prime}$ Connel onderzoekt een ding (een batterij die de eenheid vertegenwoordigt) door de sociale relaties in kaart te brengen die in het ding zijn vastgelegd en zonder welke het ding geen betekenis heeft.

In dit hoofdstuk staan wee soorten transnationale verhoudingen centraal. Ten eerste de verhouding tussen primaire en de secundaire laboratoria; ten tweede de verhouding tussen de vrijwilligers die binnen het WHO-netwerk bloed geven en de WHO. In paragraaf twee wordt beschreven met welke intenties en op welke manier de WHO de verhouding tussen de primaire en de secundaire laboratoria wil vormgeven. Vervolgens wordt nagegaan hoe de verhoudingen tussen primaire en secundaire laboratoria in de praktijk worden gevormd. Net als in de hoofdstukken twee en drie staat het werk van het registreren voorop. In dit hoofd. stuk gaat het er om hoe in dat werk de verhoudingen worden gevormd en omgevormd. In paragraaf drie worden de verhoudingen tussen de WHO en de vrijwilligers beschreven. Opnieuw gebeurt dat eerst vanuit het perspectief van de intenties van de WHO, daarna komt het registratiewerk en de effecten van dat werk op de verhoudingen centraal te staan.

\section{.2 Van internationale gelijkheid naar een transnationale taakverdeling}

Een nevendoelstelling van het WHO-netwerk is om de samenwerking tussen de primaire en de secundaire laboratoria te bevorderen. De werkgroep verwoordt deze doelstelling als volgt:

"The overall goal is to create a productive working relationship botwen primary and secondary laboratories so as to enthonce their inostigational capacily and facilitate a free exchange of ideas, reagents and melhodologies".225

De verschillen tussen de primaire en de secundaire laboratoria zijn echter groot. Terwijl de secundaire laboratoria over de meest geavanceerde apparatuur beschikken en toponderzoekers in dienst hebben, kunnen een aantal primaire laboratoria niet vertrouwen op hun water-en elektriciteitsvoorziening. De onder. zoekers van de primaire laboratoria zijn over het algemeen minder geschoold en beschikken derhalve over minder kennis en vaardigheden dan het personeel wan de secundaire labaratoria. De vraag is daarom hoe de samenwerking tussen primaire en secundaire laboratoria gestalte kriggt. In de hierboven genoemde doel. stelling met betrekking tot samenwerking tussen primaire en secundaire laboratoria wordt gesproken over het vergroten van mogelijkheden voor onderzoek. Daar wordt echter in het midden gelaten wiens onderzoekscapaciteit moet worden uitgebreid en wiens ideeën en methodologieën zullen worden uitgewisseld: 
van de primatre of van de secundaire taboratoria? Van meel af aan zit er aan de samenwerkingsdoelsteling zo een dubbelzinntheid. Hoe komen, gegeven deze dubbelzinnigheid, de verhoudingen tussen de primaire en de secundaire laboratoria precies te liggen?

\section{De overdracht van techniek}

De overdracht van techmek naar ontwikkelingslanden is in de ogen van de WHO een belangrijk instrument om verschillen in gezondheid in de wereld te verklei* nen. De kennis die in Europa en de Verenigde Staten is ontwikkeld moet ook voor ontwhkelingslanden beschikbaar zijn. In het kader van het WHO-netwerk investeent de WHO in de faciliteiten van de primaire laboratoria (zie hoofdstuk 2). Investeringen in koelkasten, wriezers en een betrouwbare elektriciteitsvoorzliening zijn nodig om de primaire laboratoria bloedmonsters te laten verzamelen die aan de eisen van de secundaire laboratoria voldoen.

Het is echter niet de bedoeling dat de primaire laboratoria alleen maar bloed. monsters voor de secundaire laboratoria verzamelen; in de toekomst zullen zij zelf uit het bloed virussen gaan isoleren en karakteriseren. Daartoe wordt een uitwisselingsprogramma opgezet. Onderzoekers van de secundaire laboratoria gaan naar de primaire laboratoria om de staf daar ter plekke bepaalde technieken te lenen. Ook nodigen de secundaire laboratoria onderzoekers van primaire laboratoria uit om enige tijd bij hen te komen werken.

Daamaast vraagt de WHO de secundaire laboratoria om technieken voor de isolatie en karakterisering van HIV over te dragem aan de primaire laboratoria. In plaats van de bestaande technieken naar de primaire laboratoria toe te brengen, worden nieuwe technieken ontwikkeld die eenvoudiger in het gebruik zijn.226 De secundaire laboratoria ontwikkelen het idee een serumplaatje te ontwerpen om daarmee het genotype van een virus te bepalen. Zo'n serumplaatje verkleurt als er bloed op wordt gedruppeld en aan de hand van de kheur kan vervolgens het genotype worden bepaald. ${ }^{227}$ De apparatuur en kennis die in de secundaire laboratoria worden gebruikt om het genotype van een virus te bepalen zijn met zo'n serumplatje niet meer nodig. Het wordt daarmee eenvoudiger om de techniek voor de karakterisering van HIV over te dragen.

De relatie tussen de primaire en de secundaire laboratoria lijkt nogal eenzijdig. Het doel wan de samenwerking tussen de primaire en de secundaire laboratoria is om de onderzoekscapaciteit in het algemeen te vergroten, maat er wordt vooral geinvesteend in de faciliteiten van de primaire laboratoria. De faciliteiten van de primaire laboratoria worden verbeterd en voor hun onderzokers worden scholingsprogramma"s opgezet. Wat schieten de secundaire laboratoria op met deze samemwerking? Hoe worden hun onderzoeksmogelijkheden in de samenwerking met de primaire laboratoria uitgebreid? Welke nieuwe ideeën of methodologieën ontwikkelen zij in het kader van de samenwerking?

Volgens de werkgroep hebben de secundaire laboratoria wel degelijk belang bij de samenwerking met primaire laboratoria. Ten eerste kunnen de secundaire laboratoria dankzij de primaire over unieke bloedmonsters beschikken voor hun onderzoek, namelijk bloedmonsters uit verre landen war het moeilijk is om 
onderzoek te doen. Ten tweede is het WHO-netwerk volgens de werkgroep een uniek samenwerkingswerband dat veel meer zal opleveren dan billterale contacten:

"(..) the metwork is an international rollaboratine study wh which the jom effort of all laboratories is expected to be more productive from a sticntific point of view and beter targeted towards ands vacine derelopment than an indizidual, bilateral or more resiricted callaborations" "228

Bij de formulering van de problemen erkent de WHO de werschillen tussen ontwikkelde- en ontwikkelingslanden, maar in de oplossing benadrukt żij juist overeenkomstige belangen. Voor het opzetten van wereldwijde pokkenvaccinatieprogramma's gebruikte de WHO een zelfide type argument. Als rijke ianden niet bereid zijn te investeren in vaccinatieprogramma's in ontwikkelingslanden, zal de dreiging wan nieuwe epidemieën blijven bestaan. ${ }^{229}$ De bestrijding van epidemieën wordt daarmee gedefinieerd als een gezamenlijk belang. De WHO wil enerzijds speciale aandacht hebben voor de gezondheidsproblematiek in ontwikkelingslanden en zet daarvoor speciale programma's op. Anderzijds benadrukt de WHO dat investeren in ontwikkelingslanden een algemeen belang is woor alle landen.

\section{Intensieve samenwerking}

De WHO bezlet de verhouding tussen de primaire en secundaire laboratoria van* uit een internationaal perspectief, dat wil zeggen de WHO will via officiële verklaringen en in samenwerking met nationale overheden hulpprogramma's opzetten om de onderzoeksmogelijkheden van de primaire laboratoria te vergroten. 230 Daarmee hoopt zij de kloof tussen de primaire en de secundaira laboratoria te overbruggen. De uitwisseling van kennis en techniek kan echter ook vanuit eem transnationaal perspectief worden beschouwd. Onderzoek naar de uitwisseling van muziek en keukens tussen ontwikkelde en ontwikkelingslanden heeft laten zien dat globalisering zich voltrekt op manieren die geheel buiten internationale verdragen of programma's om gaan (zie hoofdstuk 1). Voordat op basis van de doelstellingen van het beleid en de intenties van de betrokkenen conclusies worden getrokken over de verhouding tussen de primaire en de secundaire labo. ratoria en de bijdrage van de WHO aan het averbruggen van de verschillen, is het darom van belang te kijken naar de transnationale relaties tussen de laboratoria.

De laboratoria in het WHO-netwerk werken niet zo zeer samen in onderzaek, maar voeren eigenlijk samen één onderzoek uit. Het WHO-netwerk kan worden beschouwd als een transnationaal laboratorium. Dankzij de infrastructuur die voor het WHO-netwerk wordt opgebouwd (zie hoofdstuk 2), is het mogelijk om het werk voor de registratie van HIV aan laboratoria in diverse landen uit te besteden. De successievelijke stappen in de isolatie en karakterisering van HIV worden in laboratoria die over de hele wereld verspreid zijn uitgevoerd. Uit de bloedmonsters die in Oeganda, Ruanda, Thailland en Braziliê zijn verzameld, kunnen in Londen virussen worden geisoleend die vervolgens in onder andere 
Amsterdam, Madrid en Atlanta worden gekarakteriseerd.

Daarvoor is het echter noodzakelijk dat laboratoria hun werk in verregaande mate op elkaar afstemmen. Die eis wordt met name aan de primaire laborato. ria en het depot gesteld. De primaire laboratoria kunnen het bloed namelijk niet inviezen omdat in het depot uit het bloed nog virussen moeten worden geiso. leerd. Bloed dat niet bevroren is, kan minder goed en vooral minder lang worden bewaard. Daarom moeten de primaire laboratoria de tijdstippen waarop het bloed wordt afgenomen afstemmen op het vertrek van vliegtuigen naar GrootBrittannie. Het depot is tevoren op de hoogte gesteld wanneer de vilegtuigen waarmee de bloedmonsters worden verwoerd arrweren. Op het vliegveld staan dan auto's klaar om het bloed direct naar het depot te transporteren waar de onderzoekers al in afwachting zijn van het bloed.231

Juist omdat er zoveel moet worden geregeld en ook alles goed moet gaan, weet de technische werkgroep niet of het mogelijk is om de isolatie van de virussen uit te stellen tot in Europa. De opzet is dan ook slechts bedoeld als een tijdelijke oplossing tot het moment dat de primaire laboratoria zo zijn ingericht dat zij zelf de virussen kunnen isoleren. Zoals in hoofdstuk 3 is beschreven zijn er meer problemen dam verwacht, maar het lukt uiteindelik om uit voldoende bloedmonsters virussen te isoleren. Het blijkt mogelijk te zijn om virussen te isoleren op duizenden kilometers affstand van de plek waar het bloed is afgenomen.

Als het eenmaal mogelijk blijkt om de virussen pas in het depot te isoleren, doet het depot het voorstel om dat ook na afloop van de pilotstudy te blijven doen.

"I personally do believe to be true, what was agreed upon in January by experts, that it will be important for the success of the project that isolations are handled by as few laboratories as possible".232

Wat eerst een noodoplossing is, wordt dankzij de luchtbrug een belangrijk voordeel van het programma; in het depot kan de virusisolatie worden gecentraliseerd en gestandaardiseerd.

De intensteve samenwerking en het succes van de luchtbrug hebben kortom geresulteerd in een verschuiving van de oorspronkelik voorziene taakverdeling tussen primaire en secundaire laboratoria. In tegenstelling tot wat de bedoeling was, wordt voorgesteld om de virusisolatie niet door de primaire laboratoria te laten uitvoeren maar op een centrale plaats, in het depot. De primaire laboratoria krijgen een taak minder, maar dat is het niet het enige effect. De taakverschuiving heeft belangrijke consequenties voor de definitie en erkenning van hur wetenschappelijk werk. Daarover gaat de volgende paragraaf.

\section{Wetenschappelijk werk}

Om de samenwerking niet in gevaar te laten komen door conflicten over wie welke resultaten publiceent, worden vooraf binnen de technische werkgroep over publicatie van wetenschappelijke artikelen afspraken gemaakt. ${ }^{233}$ Uitgangspunt voor de WHO is dat iedereen die aan het onderzoek heeft meegewerkt daarwoor erkenning kringt.

Redacties van gerenommeerde wetenschappelijke tijdschriften stellen echter 
beperkende regels ten aanzien van het auteurschap van een artikel. Deze regels leggen vast wie als auteurs van een artikel kunnen worden genoemd. Het aan. tal auteurs dat samen een wetenschappelike artikel schifift is de latste decennia sterk gestegen. Dat komt enerzijds door de intemationalisering van onderzoek waardoor er gewoon meer onderzoekers aan een project meewerken. maar anderzijds is het ook een gevolg van de publicatiedruk. Om in de publicatierace mee te kunnen doen, spreken onderzoekers af om elkaar als auteur op te voeren zodat iedereen meer artikelen op zijn (of haar) naam kan schrijven. Hierdoor kan het gebeuren dat onderzoekers die weinig of niets met het onderzoek van doen hebben gehad toch als auteur worden genoemd waardoor het onduidelik wordt wie nu verantwoordelijk is voor de gepresenteerde resultaten.234

"Irresponsible anthorship, rather than multiple awthorship. was identifed as the real problem, since usually multiple authorship indicated a claim for credit rather than an acceplance of responsibility. This study indicates that 'multiple authorship' can easily become imesponsible authorship simply because it tends to debate the notion of what authorship really means" 235

In antwoord op dit probleem wordt binnen de technische werkgroep onderscheid gemaakt tussen wat als woorbereidend en wat als wetenschappelije werk geldt. Als auteur zullen alleen diegenen worden genoemd die een substantiële bijdrage hebben geleverd aan het onderzoek. De anderen zullen in het dankwoord worden genoemd. Wetenschappelijk werk is volgens de WHO:

- "conception and design, or analysis and interpretation of data;

- drafting the article or revising it critically for important intellectuall content;

- final approval of the version to be published".236

En daar buiten walt:

- "Participation solely in the acquisition of funding or the collection of data",237 Voor de primaire laboratoria betekent het onderscheid in voorbereidend en wetenschappelijk werk dat zij alleen in het dankwoord, in een voetmoot van een artikel, worden genoemd. Hun werk heeft zich immers beperkt tot het verzame. len van bloedmonsters. De technische werkgroep maakt êen uitzondering, namelijk voor artikelen die de resultaten presenteren van de karakterisering van bloedmonsters uit één specifiek land. Alleen in dat geval zullen onderzoekers van de primaire laboratoria van dat land als auteur kunnen worden genoend.

De WHO beperkt het aantal auteurs, maar er wordt ook een nieuwe auteur geintroduceerd, namelijk "het WHO-netwerk woor de isolatie en karakterisering van HIV". ${ }^{3}$ a Deze auteur sluit goed aan bil het ideaal van de WHO, omdat alle onderzoekers van het WHO-netwerk in die naam worden verenigd. Het WHO-netwerk is een auteursnaam die uitdrukking geeft aan de internationale samenwerking waarvan het artikel een product is. De introductie van deze auteur betekent echter dat geen van de onderzokers die onder deze auteur vallen krediet krigt voor het onderzoek. Als een artikel met als auteur het WHO-netwerk wordt geciteerd, worden de onderzoekers zelf niet geciteerd. Het artikel telt voor de afzonderlijke onderzoekers dan ook niet mee in de citatie-index. Voor de anderzoe. kers van secundaire laboratoria is dat meestal geen groot probleem. Zij 
publiceren reeds veel in prestigieuze wetenschappelijke tijdschriften. Voor de onderzoekers van de primaire laboratoria betekent de introductie van deze auteursnaam een gemiste kans om zich te profileren in de wetenschap.

Dankzil de infrastruttuur die voor het WHO-netwerk wordt opgebouwd, kunnen bepaalde onderdelen van het onderzoek waarvan eerst wordt gedacht dat die beter in ontwikkelingstanden kunnen worden uitgevoerd, zoals de virusisolatie, nu in de westerse laboratoria worden uitgevoerd. Daamaast geldt dat zolang de primaire laboratoria alleen bloedmonsters verzamelen, hun werk niet gezien wordt als een substantiêle bijdrage aan het onderzoek en de onderzoekers derhalve geen auteur wan een wetenschappelijke artikel worden. Hoewel de WHO de faciliteiten wan de primaire laboratoria heeft helpen opbouwen en uitbreiden voor deelname aan het WHO-netwerk, heeft de transnationale werkverdeling tussen de laboratoria de verschillen tussen de primaire en de secundaire laborato. ría eerder vergroot dan verkleind.

Zoals in de inleiding van dit hoofdstuk al is aangegeven heeft de WHO hel verwijt gekregen te weinig te investeren in ontwikkelingslanden. In het geval van het WHO-netwerk heeft de WHO echter duidelijk de intentie om de samenwerking tussen primaire en secundaire laboratoria op het gebied van onderzoek te bevorderen. De WHO neemt daarvoor ook verschillende initiatieven, zoals het doen van investeringen in de faciliteiten van de primaire laboratoria en is zich van de problemen bij de overdracht van geavanceerde technieken bewust. In dat kader past het serumplaatje. In plaats van in ontwikkelingslanden enkele hoog technische laboratoria in te richten, werken de secundaire laboratoria aan de ontwikkeling van een serumplaatje waarmee op een eenvoudige manier het genotype van een virus kan worden bepaald.

Goede bedoelingen en initiatieven ten spijt, de praktijk werkt anders uit. Het transnationale netwerk van de laboratoria volgt een eligen ontwikkelingslogica die de WHO slechts ten dele kan sturen. De taakverdeling tussen de primaire laboratoria en de secundaire laboratoria waarbij de eersten het onderzoeksmateriaal verzamelen voor de tweeden, is het onverwachte en onvoorziene resultaat van allerlei keuzes die in het proces van registreren zijn gemaakt. De opbouw van de infrastructuur voor het transport van bloedmonsters was niet bedoeld voor centralisatie van virusisolatie, maar creëerde wel precies die mogelijkheid. Wie had gedacht dat het voorstel om de virussen centraal te blijven isoleren betekent dat het werk van de primaire laboratoria niet als wetenschappelijk arbeid geldt en zij daarom uitgesloten worden als auteur van wetenschappelijke publicaties?

\section{.3 Een carrière in onderzoek voor patiënten}

Binnen het WHOmetwerk werken niet alleen onderzoekers, maar functioneren ook de wrijwilligers die bloed geven voor het onderzoek. Onderzoek doen in ontwikkelingslanden kan gevoelig liggen. Toen de WHO in 1993 besloot de vaccinstudies in ontwikkelingslanden door te laten gaan terwijl het $\mathrm{NIH}$ besloot om 
dergelijke studies in de Verenigde Staten uit se stellen (zie hoordstuk 2), werd de WHO onmiddellik gevraagd of zij wel voldoende rekening hield met de belan. gen van mensen in ontwikkelingslanden. Het besluit riep de vraag op of de WHO ontwikkelingslanden beschouwt als een proefuin war vaccins getest kumnen worden, om ze pas wanneer deze vaccins veilig en effectief zijn gebleken in Europa en de Verenigde Staten te testen.239 De WHO zet de vaccinstudies niet met die intentie op. De WHO wil vaccins in ontwikkelingslanden testen zodat die landen als eerste vaccinatieprogramma's kunmen gaan opzetten. ${ }^{240}$ Bovendien wil de WHO de verhouding tussen de vrijwilligers en de laboratoria volgens internationale afspraken en rechten regelen.

\section{Met toestemming}

De WHO heeft een toestemmingsverklaring opgesteld waarin de relatie tussen de vribilliger en het WHO-netwerk wordt beschreven en vastgelegd. De toestemmingsverklaring is gebaseerd op de "International Convenant on Civil and Political Rights", een intermationaal verdrag dat alle lidstaten hebben ondertekend. Daarin staan de rechten die mensen hebben die aan een onderzoek meedoen. Niemand mag tegen zijn of haar wil onderworpen worden aan medische of wetenschappelijke experimenten. Om dat te garanderen zijn onderzoekers verplicht de vrijwiligers te vragen expliciet toestemming te verlenen voor deelna. me aan een experiment en die toestemming is alleen geidig als zij over het experiment zijn geunformeerd. Ook is vastgelegd wat een vrijwilliger over een experiment behoort te weten waaronder informatie over de reden om het experiment uit te voeren, hoe het experiment is opgezet, en wat de ongemakken en risico's zijn bij deelname. ${ }^{24 !}$ De toestemmingswerklaring is een afgeleide van deze rechten, waarim al deze aspecten te herkenmen zijn (zie figuur 6).

De toestemmingsverklaring geeft een specifiek beeld van de relatie tussen de WHO en de vrijwilligers. Ten eerste wordt de relatie tussen de vrijwilliger en de WHO als tijdelijk voorgesteld. De vrijwilliger kan volgens de toestemmingsverklaring namelijk op elk moment besluiten om met het onderzoek te stoppen. Bovendien wordt alleen toestemming gevragd voor een bloeddonatie en voor het afnemen van een korte enquête. Deelname aan het onderzoek wordt in de toestemmingsverklaring gekoppeld aan éên bepaald moment, de dag waarop de vrijwilliger naar het laboratorium komt en bloed laat afnemen.

Ten tweede wordt de toestemmingsverklaring ondertekend door de vrijwilliger en een onderzoeker wan het primaire laboratorium, hetgeen de suggestie wekt dat alleen zij twee een verbintenis met elkaar aangaan. Vertegenwoordigers van het depot war het afgenomen bloed wordt bewaard, van de secundaire laboratorila waar het bloed wordt onderzocht en van de WHO die samen met het LANL de gegevens registreren andertekenen de verklaring niet.

Naar aanleiding van de plannen om in ontwikkelingslanden HIV-vaccinstudies op te zetten, wordt een debat gevoerd over de vraag of de voorwarden woor deelname aan dergelijke studies moeten worden aangepast aan de cultuur in het land. Een deel van de onderzoekers die de vaccinstudies aan het voorbereiden zijn, vindt dat het mogelijk moet ziin om de toestemmingsverklaring door een 
Figuur 6: De toestemmingswerklaring.

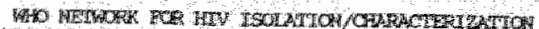

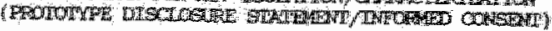

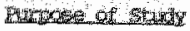

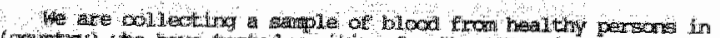

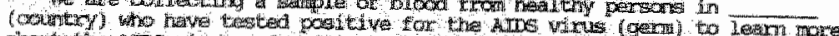

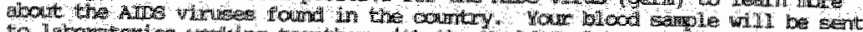

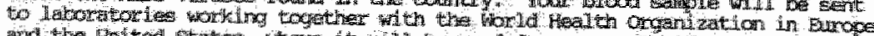

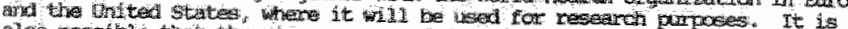

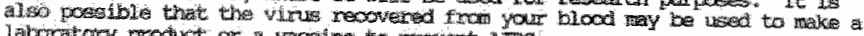

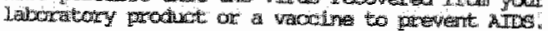

tedures

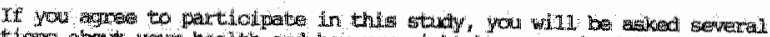

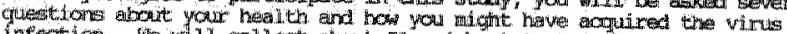

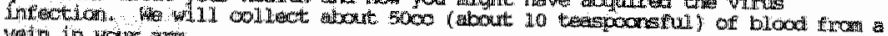
veatilin in wour artit.

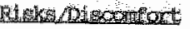

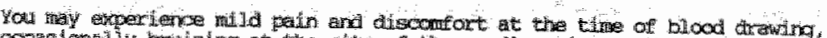

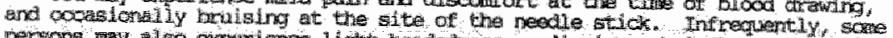

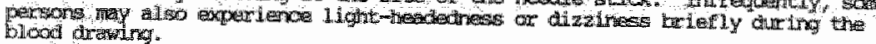

\section{pensus}

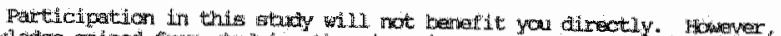

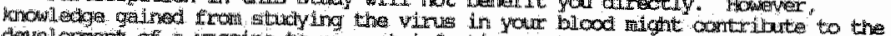
developmint of a vacethe to preverit infection or AIDS, that weula benefit mankind.

\section{Hisernatuse}

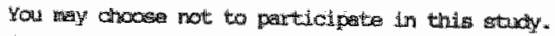

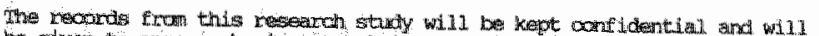
not beglven to aryone who is not halping on this stiviy, unless you wore to hate the recordis givini oxts.

You should assk the preincipal investulgator any question you

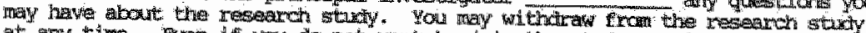

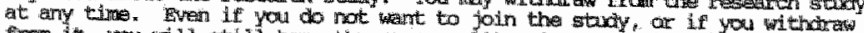
from: it, you will stin have the cuality of care avaliable to you itc

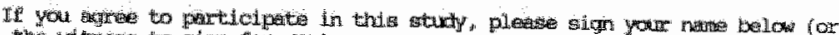
tobill the withess to aidg for youl.

Signiterite of mitiness or subject

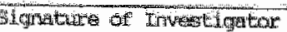

$\frac{\text { Date }}{\text { Date }}$

Bron: WHOIGPAWCU/Technical Working Group on HIV Isolation and Characterization (II992). Inikial Characterization of HW-1 isolates from WHO-sponsoned vaccine evaluation sires, $13-15$ januari, Geneve.

ander dan de vrijwilliger te laten tekenen.242 Dat zou bijvoorbeeld kunnen worden gedaan door het hoofd van de famille of van de leefgemeenschap als dat in het land gebruikelik is. De toestemmingsverklaring van de WHO sluit die optie echter uit. Als een ander de toestemmingsverklaring al tekent, dan is dlat een getuige. Zijn of haar rol is te getuigen dat de vrijwilliger toestemming heeft gege- 
ven en dus niet om voor de vrijwitiger een keuze te maken. Van de vrijwithiger wordt verwacht dat die zelf als individu toestemming geeft.

De WHO wil de verbintenis tussen de primaire laboratoria en de viliwilligers vorm geven binnen het internationale juridische en politieke kader. De autonomie van viliwiligers staat daarbij voorop. Autonomie word daarbij op twee manieren uitgelegd. Ten eerste krijgt autonomie de betekenis van onafhankelikheld. De onafhankelijkheid vam de vrijwilligers ten opzichte van de primaire laboratoria krijgt gestalte in de clausule dat de wrijwilliger op elk moment kan beslissen om van verdere deelname aan het onderzoek af te zien. Deelname aan het onderzoek wordt beschouwd als een keuze, een bestissing die op elk moment kan worden herzien. Ten tweede wordt autonomie ingevuld als ongebondenteid. De keuze om aan thet onderzoek mee te doen wordt gezien als een individuele besissing. De vrijwilliger moet degene zijn die beslist deel te nemen aan het onderzoek. Binnen de internationale juridische kaders van de WHO wordt deelname alan het onderzoek kortom gezien als een individuele keuze.

\section{Een carrière in trials}

De toestemmingsverklaring heeft betrekking op de karakterisering van het virus en het bloed dat daarvoor wordt afgenomen. In de toestemmingsverklaring wordt echter niets gezegd over de registratie van gegevens over de vrijwilligers, noch over de resultaten van karakteriseringen, noch over de opslag van het bloed in het depot. Registreren doet geen pijn en heef, mits de privacy wordt bewaakt, geen risico's voor de vrijwilliger. Dat laat echter onverlet dat het registratieproces wel degelijk effecten kan hebben voor de vrijwilliger. Wat zijn die effecten? In het vorige hoofdstuk is het proces van registreren beschreven in termen van mobiliseren, stabiliseren en combineren. Hoe dragen deze drie facetten van het proces van registreren bij aan de relatie tussen vrijwilligers en de WHO?

In werkelijkheid is de relatie van de vrijwilliger met het WHO-netwerk veel langdurige en complexer dan in de toestemmingsverklaring wordt verondersteld. Dat wil zeggen dat vrijwilligers en de WHO op meer manieren met elkar verbonden zijn en dat hun afhankelijkheidsrelaties moeiliker te overzien zijn, dan in die verklaring wordt aangenomen. De technieken om te registeren maken, zoals in hoofdstuk 3 is betoogd, het mogelijk om bloed en gegevens van een vrijwilli. ger op eén plaats bij elkaar te brengen en lange tijd te bewaren. Wat betekent dat voor de vrijwilligers en voor hun relatie met de WHO? De belangrijkste consequentie is dat de WHO het bloed en de gegevens ook voor andere onderzoeken kan gaan gebruiken en daarmee de vriwilligers blift volgen. Een deel van de wrijwilligers die bloed geeft voor het WHO-netwerk heeft bijwoorbeeld al eerder meegedaan aan een cohortstudie om de HV-incidentie te bepalen. Deze wrijwilligers zijn makkelijk te "vinden' omdat zij al geregistreerd staam. Deze vrij" willigers doen mee aan hun tweede onderzoek. Waarschijnlijk is dat ook niet het laatste waarbij ze betrokken warden. Om dezelfde redenen waarom vrijwilligers zijn gevraagd te participeren in het WHO-netwerk zullen onderzoekers die HW. vaccinstudies voorbereiden overwegen hen te vragen aan die vaccinstudies mee te doen. 
In een arthel warin Helen Epstein haar ervaringen met aidsonderzoek in Oeganda beschrifft, makt zij onderscheid tussen thin and fat aids. ${ }^{243}$ Patienten thet aids worden nat mate de ziekte vordert steeds dunner, $z$ il hebben thin aids. Daarentegen hebben onderzoekers fat aids, dat wil zeggen zij varen wet bij de ziekte ondat die kansen biedt voor hun carrière. Hoewel de wrijwilligers ef niet "dikker" van worden, maken ook zij een carrière in het onderzoek. Hun carnere komt echter niet voort uit ambitie, maar is het resultaat van de regis. tratie van gegevens. Dankzil de opslag van gegevens kan de WHO de wrijwilligers over langere tijd blijven volgen en blijven de wrijwilligers aan de WHO verbonden zonder dat er direct contact is zoals bij de afname van het bloed.

De techniek van registreren creëert niet alleen relaties tussen de WHO en de vrijwilligers, maar ook relaties tussen de vrijwilligers onderling. De primaire laboratoria hebben twee methoden overwogen om viliwilligers te volgen - het gemeenschapscohort en een cohort voor ziekenhuispatiènten.244 Men kiest uiteindelijk voor het ziekenhuiscohort. De afweging die hier aan vooraf is gegaan, maakt zichtbaar hoe gedurende de registratie cle onderlinge relaties tussen de vrijwilligers worden getransformeerd.

Het Oegandese laboratorium overweegt aan het begin van de pillotstudy om een gemeenschapscohort op te zetten om de vrijwilligers te kunnen valgen. 245 In een kleine gemeenschap kan de onderzoeker de vrijwilligers eenvoudig volgen. Men hoeft niet ver te reizen om alle vrijwilligers af gaan en dat biedt onderzoekers de mogelijkheid om zelf naar de vrijwilligers toe te gaam in plaats van de vrijwilligers naar hun laboratorium te laten komen. In dat laatste geval bestaat het risico dat die hun afspraken niet nakomen. Deze manier van volgen wordt ook wel een actieve follow-up genoemd. Bovendien kan de onderzoeker de onderlinge relaties van de vrijwilligers gebruiken om hen steker bij het onderzoek te betrekken en daarmee hun trouw aan het onderzoek te vergroten. Weniger die de WHO adviseert over de beste follow-up methode geeft het voorbeeid van een dorpsonderwijzer die zijn leerlingen en ouders aan het onderzoek kan binden. Een potentiète vrijwilliger, zo weronderstelt Weniger, zal zich eerder door de onderwijzer latten overtuigem om aan onderzoek mee te doen dan door een voor hem of haar onbekende onderzoeker. 240

Ondanks deze voordelen ziet het laboratorium uiteindelijk toch af van een gemeenschapscohort omdat de opzet van de studie veel vragen oproept bij de vrijwilligers die de ondezzekers in een lastig pakket brengen.

"Conmunity based cohorts have even more problems. The communities do not usually understand why one person in a village should be invited into a new imvestigation the the extusion of athers" 247

Het probleem is nametijk dat de onderzoekers de vrijwilligers de opzet van de studie moeilijk kumnen uitleggen zonder te verklappen wie van de vrijwilligers seropositief is. De opzet van de studie verdragt zich niet met de belofte van anonimiteit voor de vrijwilligers.

Het Degandese laboratorium kiest daarom uiteindelijk voor een cohort van ziekemhuispatienten. ${ }^{248}$ Tussen het ziekenhuiscohort en het gemeenschapscohort 
bestaan twee belangrijke verschillen. Het eerste verschil is dat de ziekenhuispatiënten niet actief door de onderzokers worden gevolgd. De onderzoe kers maken gebruik van het feit dat patienten regelmatig naar het ziekenthuis komen en wachten de vrijwilligers daarop. Het tweede verschil is dat hussen de ziekenhuispatiënten geen onderlinge relaties bestaan. De groep waaruit de patiënten geselecteerd wordt, is namelijk veel groter. Het oegandese laboratorium rekruteert de patiènten in het enige ziekenhuis van Entebbe, de hoofdstad van het land. Uiteraard kan het gebeuren dat twee ziekenhuispatiénten elkaar kennen, maar dan zullen zij elkaar niet herkennen als wrijwilligers van een onder. zoek. Mensen worden in een ziekenhuis op de eerste plaats herkend als patienten en niet als deelnemers aan een onderzoek. Binnen het cohort van zieken. huispatiënten bestaan met andere woorden weinig onderlinge betrekkingen en de onderlinge relaties die bestaan worden door de opzet van de trial onzichtbaar gemaakt.

De keuze voor het ziekenhuiscohort zorgt ervoor dat de testresultaten van de vrijwilligers vertrouwelijk blijven. Tegelijkertijd wordt er echter een ander probleem gecreëerd. Wanneer vrijwilligers te horen krijgen dat zij seropositief zijn, weet niemand dat - behalve zijzelf en de onderzoeker. De vrijwilligers worden voor de lastige keuze gesteid of zij anderen zullen vertellen dat zij seropositief zijn. Als zij het anderen vertellen, dan lopen zij het risico veel te verliezen.249 Als zij de uitslag van de HIV-test geheim houden staan zij er alleen voor de voor hen negatieve testuitslag te verwerken.

Met andere woorden, de twee cohortmethoden bouwen verschillende netwerken op. In het netwerk van het gemeenschapscohort zijn de vrijwilligers onderling met elkaar verbonden. In het tweede netwerk bestaan tussen de vrijwilligers geen onderlinge relaties - hoogstens zijn deze van een toevallige aard - en zijn de vrijwilligers vooral met elkaar verbonden via de onderzoekers. Dit tweede metwerk trekt bovendien een grens tussen het onderzoek waarin bekend is dat mensen seropositief zijn, maar dat heeft geen consequenties naar de wereld buiten het onderzoek waar seropositiviteit wel grote consequenties heeft en het voor een vrijwilliger beter kan zijn dat de uitslag van een aids-test onbekend blijft.

Binnen de formele en politieke verhoudingen waar de WHO meestal haar vertrekpunt kiest, wordt een strikt onderscheid gemaakt tussen het internationale. nationale en lokale niveau. Het is de taak van een internationale organisatie als de WHO de samenwerking tussen mationale staten te bevorderen. Om de afspra. ken die op het internationale niveau op het nationale en lokale niveau te reallseren, is de WHO afhankelijk wan nationale overheden. Nationale overheden worden verondersteld de intermediair of brug te zijn tussen het internationale en het lokale niveau.

Wanneer echter de transnationale verbintenissen in kaart worden gebracht die in het proces van registreren worden opgebouwd, blijkt dat een internationale organisatie als de WHO wel degelijk ook verbonden is met individuele burgers op het lokale niveau. Bovendien heeft het proces van registreren invloed op de onderlinge verhoudingen tussen vrijwilligers op dat lokale niveau. Er wordt geko. 
zen woor een onderzoeksopzet die hun onderlnge relaties in het onderzoek verzwakt on hun relaties met de activiteiten van de WHO te kunnen versterken.

\section{.4 Slot}

Met de opzet van het WHO-netwerk wil de WHO de samenwerking tussen ontwikkelingslanden en ontwikkelde landen bevorderen in thun strijd tegen aids. De WHO wil dit doen door enerzijds het onderzoek haar HW in ontwikkelingslanden te stimuleren en anderzijds de resultaten van de registratie van de diversiteit van HIV direct in te zetten voor de ontwikkeling van vaccinstudies in die landen. Daarnaast streeft de WHO naar gelijkwaardige verhoudingen tussen zowel de primaire en de secundaire laboratoria, als de vrijwilligers en het WHOnetwerk. In een officiele overeenkomst met de WHO verplichten de laboratoria zich kenris en wardigheden uit te wisselen en alle vrijwilligers die aan het onderzoek mee doen hebbem een verklaring ondertekend warim zil expliciet aan de primaire laboratoria toestemming hebben gegeven bij hen voor het onderzoek bloed af te nemen. De intentie van de WHO is daarbij om de positie van respectievelijk de primaire laboratoria tegenover de secundaire laboratoria en de vrijwilligers tegenover het WHO-netwerk te beschermen en zo mogelijk te versterken.

De WHO heeft verschillende initiatieven genomen om dergelijke intenties waar te maken. In het kader van het WHO-netwerk zijn er bijwoorbeeld trainingsprogramma's opgezet voor onderzoekers voor de primaire laboratoria en wordt een eenvoudige techniek ontwikkeld waarmee de primaire laboratoria zelf het genotype van HIV kunnen bepalen. In het proces van registreren worden echter allerlei keuzen gemaakt die op het eerste gezicht niets te maken lijken te hebben met de verhoudingen tussen de primaire laboratoria en de secundaire laboratoria of met de verhouding van vrijwilligers tot thet WHO-netwerk, zoals het voorstel om de isolatie van HIV te centraliseren of de afspraken die worden gemaakt over de publicatie van de resultaten. Het zijn onafhankelijke beslismomenten waarbij verschillende afwegingen worden gemaakt, maar samen leiden die keuzen er toe dat de primaire laboratoria minder taken krijgen dan oorspronkelijk de bedoeling was en hun arbeid niet als wetenschappelijk werk wordt beschouwd, waardoor zij uitgesloten worden als auteur valn wetenschappelijke artikelen. Op soortgelijke wijze worden wijwilligers, zonder dat zij daarvoor toestemming geven voor langere tijd gebonden an het onderzoek van de WHO. De afloop van het registratieproces frustreert en transformeert de goede bedoelingen van de WHO zo op tal wan punten.

In hoeverre was deze ontwikkeling van de verhoudingen in het WHO-netwerk tussen respectievelijk de primaire en de secundaire laboratoria en de viljwilli. gers en de WHO onvermijdelijk? Hadden de transmationale verhoudingen in het WHO-netwerk ook anders kunnen uitpakken? De wijze waarop de transnationale verhoudingen zich in het WHO-netwerk hebben ontwikkeld, is zoals gezegd het resultaat van afzonderlijke keuzen. Die maken geen onderdeel uit van een 
vooropgezet plan of een algemene beweging. Het is echter niet toevallig dat de som van afzonderlijke keuzen wel een richting heeft. Er is immers al een bepaalde infrastructuur opgebouwd voor respectievelijk het werven van vijwilligers en het verzamelen en isoleren van bloedmonsters en daardoor liggen bepaalde keuzen meer voor de hand dan andere. De primaire laboratoria kunnen bijvoorbeeld ook viijwilligers selecteren die nog niet eerder aan een onderzoek van de WHO hebben meegedaan en na het onderzoek de gegevens vernietigen. De laboratoria zullen dan wel meer werk moeten verrichten om vrijwilligers te binden aan hun onderzoek. Wat er in de praktijk gebeurt draagt ertoe bij dat afzonderlijke besluiten allen in dezelfde richting graviteren. Zonder extra werk worden in de ontwikkeling van het netwerk de sterke bindingen nog sterker en de zwakkere nog zwakker. 

kennisorganisatie

\section{De WHO als netwerkbouwer}

\section{.1 Introductie}

Discussies aver de WHO warden gedomineerd door de tegenstelling tussen wetenschap en politiek. Het begint bij de WHO die zich presenteert als een technische en a-politieke organisatie. Dat beeld van de WHO komt op allerlei manie. ren tot uitdrukking: in de structuur van de organisatie, de taakopvatting, de keuze van programma's en de verhalen die over de WHO worden verteld (zie hoofdstuk 1). Zelfs de critici nemen voetstoots aan dat de WHO ook inderdaad een technische en a-politieke organisatie is. Een belangrijk deel van hun kritiek is gericht op de procedures, de commissies en de vergaderingen van de WHO. Zij vinden de organisatie te bureaucratisch. 250 De bureaucratische regels maken de organisatie inefficient en ineffectief. Er wordt te veel tijd besteed aan verga. deren en aan het schrijven wan rapporten waardoor te weinig terechtkomt van het beleid van de WHO. De kritiek reikt echter verder dan de uitvoering van het beleid. Ook op de inhoud van het beleid is kritiek. Critici vinden het beleid van de WHO te technisch of te eenzijdig gericht op de ontwikkeling van mediscthe kennis en technische voorzieningen in de gezondheidszorg. 251 zij verwachten een meer politieke rol van de WHO en bevestigen daamee de veronderstelde tegenstelling tussen wetenschap en politiek.

Het doel van dit slothoofdstuk is om op basis van de inzichten uit deze studie over het werk van de WHO een ander beeld van die organisatie te geven. Tegenover het beeld van de WHO als een technische en a-politieke organisatie, wordt in dit hoofdstuk de WHO beschreven als een transnationale organisatie die kennispolitiek bedrijft. Dit alternatieve beeld van de WHO wijkt op twee belangrijke punten af van het zelfoeeld. Ten eerste wordt aan wetenschappers en wetenschappelijke kernis een andere rol toegekend. Ten tweede wordt de 
rol van de WHO als een internationale organisatie herien. De vraag die daarbif centraal stat is hoe ver het netwerk wan de WHO reikt.

De vraggstelling van deze studie is het uitgangspunt: Welk werk heeft de WHO verricht on te kunnen registreren en wat zijn de effecten wan dat werk op de ontwikkeling van kennis, beleid en internationale verhoudingen. Het hoofdstuk is als volgt opgebouwd. Paragraaf twee beschriftt de inspanningen die worden verricht om te kunnen registreren. Paragraaf drie laat zlen hoe hel proces van registreren effect heeft op de ontwikkeling van kennis, beleid en internationale verhoudingen. In paragraaf vier staat de vraag centraal hoe technisch de WHO nu eigenlijk is, om ten slotte in paragraaf vijf een aantal centrale veronderstel lingen over het functioneren van de WHO in een ander perspectief te kunnen plaatsen. De allerlaatste paragraaf gaat terug naar de discussie over de WHO (zie hoofdstuk 1). In welke richting kan de WHO zich in de toekomst het best ontwikkelen, is daarbij de centrale vraag.

\section{.2 De inspanningen van de WHO om te registreren}

Als beleid wordt ontwikkeld, blijken meer dan eens de nodig geachte gegevens af ciffers te ontbreken. Als er wel gegevens voor handen zijn, voldoen die om een aantal redenen niet. De beschikbare gegevens blijken bijvoorbeeld niet volledig te zijn, niet specifiek genoeg woor de beleidswraag of onvoldoende betrouwbaar. De eerste stap in de ontwikkeling van beleid is dan ook veelal het verzamelen wan de benodigde gegevens.

In 1989 staat de WHO voor de vraag of doorgaan met de ontwikkeling van HIVvaccins verantwoord en zinvol is. Een effectief HIV-vaccin is dan nog niet voorhanden en het is sterk de vraag of $20^{\prime} n$ vaccin - gezien de bijzondere eigenschappen van HIV - wel ontwikkeld kan worden. Tegelijkertijd zijn grontschalige vaccinatieprogramma's het enige alternatief om ook in ontwikkelingslanden aids te kunnen bestrijden. Dat zijn namelijk de landen waar het virus zich het snelst verspreidt. De WHO wil eerst meer gegevens over HIV verzamelen voordat vaccinstudies worden gepland. Er worden al gegevens over HIV verzameld, maar de WHO vindt die gegevens te beperkt. ${ }^{252}$ De meeste HIV-registraties hebben alleen gegevens over de genetische diversiteit wan HIV, de WHO will ook gegevens over de antigene diversiteit. Om die reden zet de WHO een nieuwe registratie op: een registratie war naast elkaar gegevens over de genetïsche en de antigene diversiteit van HIV komen te staan.

Het opzetten van een registratie is makkeliker gezegd dam gedaan. Beleidsmakers, maar ook onderzoekers, realiseren zich vaak onvoldoende welk werk is gemoeid om gegevens te verzamelen. ${ }^{253}$ zij zijn vooral geïnteresseend in het product - de cijfers of de gegevens - en minder in het proces van registreren. Omdat er zo weinig aandacht is voor het proces van registreren, wordt te snel gedacht dat gegevens wel voorhanden zijin en met een simpele druk op de kmop vanzelf uit de computer komen rollen. De verontwaardiging is dan ook groot als blijkt dat de gegevens er niet zijn en vooral als de ontbrekende gege- 
vens niet op korte termijn kunnen worden geleverd.

Deze studie laat zien hoeveel werk wordt verricht om te kunnen registreven. Hoofdstuk 3 beschrift het proceswan registreren wanaf het allereerste begin het rekruteren van bloeddonoren in vier ontwikkelingslanden - tot aan het invoeren van de gegevens in de database van het LANL. Het proces van registreren kan, zo blijkt, niet simpel worden samengevat als het verzamelen van gegevens. Er komt veel meer bij kijken. In het wetenschaps-en techniekonderzoek wordt aandacht gevraagd voor het (hand-)werk van wetenschappers. De studies van onder andere Latour en Knorr-Cetina hebben laten zien hoe laboratoriumweten. schappers voortdurend bezig zijn met instellen en bijstellen van instrumentem, het bewerken van onderzoeksmateriaal en het produceren van papier: ${ }^{25 *}$ Een gedetailleerde beschrijving wan het proces van registreren is nodig om voor te kunnen stellen welk werk voor het registrerem van gegevens wordt verricht.

Elke stap in het registratieproces, zo blijkt uit de voorafgaande hoofdstukken, kost meer werk dan voorzien. Er wordt in het proces van registreren dan ook voortdurend naar alternatieve werkwijzen gezocht om de hoeveelheid werk te reduceren. Veel werk blijft nodig om tot betekenisvolle gegevens te komen. Toch is er zelden aandacht voor dit werk. 255

Beleidsmakers en onderzoekers realiseren zich waarschijnlijk wel dat gegevens niet klaar liggen om in een database te worden ingevoerd, maar laten het werk om te kunnen registreren veelal onbesproken. Ze hebben - zo lijkt het - ook geen reden om zich in dat werk te verdiepen. Wat zou het verdere belang van dit soort organisatorisch werk zijn behalve dat het moet gebeuren (en het liefst op een zo efficiënt mogelijke wijze)? Wie zich wel verdiept in dit soort werk zal echter zien hoe het invioed heeft op de ontwikkeling van beleid en kennis.

\section{.3 De effecten van registreren}

De afgelopen jaren heb ik mij verdiept in de vergaderstukken van de technische werkgroep waaronder notulen, conceptrapporten, memo"s, brieven en tabellen. Wat makkt die documenten zo interessant voor een jarenlange studie? Wat vertellen die vergaderdocumenten over de ontwikkeling van kennis, beleid en internationale verhoudingen?

De ontwikkeling van de HIV-registratie begint met een aantal vergaderingen van de technische werkgroep. Op de vergaderingen maken de leden van de werkgroep afspraken wie wat gaat doen. De primaire laboratoria zullen elk 60 bloed. monsters verzamelen, het $N 1 S C B$ in Londen zal de verzamelde bloedmonsters opslaan, bewerken en distribueren naar de secundaire laboratoria. De secundaire laboratoria zullen elk op hun eigen wijze de virussen karakteriseren. Het LANL zal ten slotte alle gegevens werwerken en invoeren in een database. Tijdens de vergaderingen worden afspraken gemaakt. Is dat het enige wat er in de vergaderingen gebeurt?

Vergaderen wordt vaak niet gerekend tot het echte werk. Er wordt wel veel vergaderd, maar weinigen zullen hun werk typeren als vergaderen. Dat geldt zeker 
voor de leden van de tectnische werkgroep. Het zijn allemaal laboratoriumwetensthappers. Het werk in het laboratorium zullen zij eerder als hun echte werk zien dan vergaderen. Zelfs als zif meer tijd kwijt zijn aan vergaderen en ander regelwerk dan aan het feitelfjke uitvoeren wan experimenten of het schrijen aan wetenschappelike artikelen.

De vergaderingen bliken belangrijker te zijn voor de inhoudelijke ontwikkeling van de registratie dan gedacht. ${ }^{256}$ De analyse in hoofdstuk twee laat zien hoe in de vergaderingen van de technische werkgroep de standpunten in het debat over de diversiteit van HIV en de effecten daarvan op de effectiviteit van een HIV-vaccin worden geordend: In de vergaderingen van de werkgroep worden de experimenten om de genetische en de antigene diversiteit van HIV te onderzoeken als aparte onderwerpen besproken. Zo worden de experimenten niet tegenover elkaar gezet, maar naast elkaar waardoor een discussie over de ver. houding tussen de genetische en de antiggene diversiteit van HIV niet gevaerd hoeft te worden.

Volgens dezelfde ordening worden ook de rapporten geschreven, de experimenten uitgevoerd en de gegevens opgeslagen. In het projectwoorstel worden de verschillende experimenten om HIV te karakteriseren achter elkaar beschreven. Het voorstel wordt een aantal keren herschreven. De opzet van het project verandert daarbij weinig, het accent ligt op het bijschaven van de tekst. In die opeenvolgende versies van het voorstel wordt het doel van de registratie om zowel de genetische als antigene diversiteit van HIV in kaart te brengen, wel steeds steviger ingebed in het aids-beieid van de WHO. De bloedmonsters en de infrastructuur maken het mogelijk om HIV langs de verschillende laboratoria te sturen; elk brengt de genetische of de antigene diversiteit in kaart, maar samen geven zij een overzicht van de genelische en de antigene diversiteit. Ten slotte worden de gegevens over de genetische en de antigene diversiteit naast ellkaal in de database van het LANL opgeslagen.

De orde van de vergaderingen verandert de verhouding tussen de verschillende experimenten. Het lijkt er op alsof die ordening alles bepalend is voor de ver* dere ontwikkeling wan de registratie en dus ook voor de verhouding tussen de genetische en de antigene diversiteit. Dat is echter niet zo. Het ligt anders. De vergaderingen zijin eên van de vele organisatorische bindingen die de verhoudingen tussen de laboratoria, de experimenten en de gegevens vormen en in stand houden. $25 \%$ Samen maken de organisatorische bindingen de verhouding tusser de genetische en de antigene diversiteit sterk.

Organisatorisch werk kan ook de bestaande ordeningen reproduceren. ${ }^{258}$ in hoofdstuk drie wordt beschreven hoe de WHO uit praktische overwegingen besluitt om de gegevens over de genetische en de antigene diversiteit op te slaan in een database van het LANL. Hel LANL heeft al een infrastructuur opgebouwd voor de registratie van gegevens over HIV. Door gebruk te maken van de infrastructuur van LANL bespaart de technische werkgroep zichzelf een hoop extra werk - de groep hoeft dan immers niet zelf een infrastiructuur op te zetten om de gegevens te kumnen verzamelen. Die overwegend praktische keuze blikkt echter ook belangrijke inhoudelijke consequenties te hebben voor de inhoud van de 
registratie. Het doel van de HV-registratie is om de genetische en de antigene diversiteit van HIV in kaat te brengen en daarmee onderscheidt de registratie zich van andere HIV-registraties die alleen gegevens over de genetische diversiteil van HIV hebben. Dat laatste geldt ook voor de HIV-registratie van het LANL. De database van het LANL is ingericht voor gegevens over de genetische diversiteit van HIV. Voor de registratie vall gegevens woor het WHO-netwerk kiest het LANL dezelfde databasestructuur als die van haar internationale HIV-sequencedatabase. De LANL database wordt uitgebreid door extra ruimte te creèren voor gegevens over de antigene diversiteit van HIV. De structuur van de database blijkt meer dan een worm waarin de gegevens worden gegoten, het vormt de inhoud van de registratie. Door gebruik te maken van de infrastructuur van het LANL, reproduceert het WHO-netwerk de (scheve) verdeling in de aandacht voor de genetische en de antigene diversiteit van HIV in de discussie over de effectiviteit van HIV-vaccins. Het is de laatste stap in een lange reeks van allerlei praktische beslissingen die op verschillende momenten in het proces van registreren worden gemaakt en die er samen toe leiden dat antigene diversiteit wordt gevormd naar en ondergeschikt gemaakt aan de genetische diversiteit.

Op soortgelijke wijze worden in het WHO-netwerk de verschillen tussen de pri. maire laboratoria en de secundaire laboratoria gereproduceerd. Met de opzet van het WHO-netwerk wil de WHO de samenwerking tussen ontwikkelingslan. den en ontwikkelde landen in de strijd tegen aids bevorderen. De WHO will de resultaten van de registratie direct kunnen inzetten voor de ontwikkeling van vaccinstudies in ontwikkelingslanden. Daarom worden de bloedmonsters in die landen verzameld. Daarbij wil de WHO de samenwerking in onderzoek tussen de primaire en de secundaire laboratoria bevorderen. In een officièle overeenkomst met de WHO verplichten de laboratoria van het WHO-netwerk zich om kennis en vaardigheden uit te wisselen. De goede intenties van de WHO ten spijt, de praktijk werkt anders wit.

Dankzij de infrastructuur die voor het WHO-netwerk wordt opgebouwd, kunnen bepaalde onderdelen van het onderzoek waarvan eerder is gedacht dat die alleen in ontwikkelingslanden kunnen worden uitgevoerd, nu in de Europese en Amerikaanse laboratoria worden uitgevoerd. Een voorbeeld is de virusisolatie. De virusisolatie kan dankzij de infrastructuur voor het transport van bloedmonsters op een centrale plaats worden uitgevoerd, waardoor standaardisatie van de virusisolatie beter mogelijk wordt. Zolang de primaire laboratoria alleen bloedmonsters verzamelen, wordt hun werk echter niet gezien als een substantiële bijdrage aan het onderzoek en kunnen de onderzoekers derhalve geen auteur van een wetenschappelijk artikel worden. ${ }^{259} \mathrm{Zij} \mathrm{krijgen} \mathrm{geen} \mathrm{stem} \mathrm{in} \mathrm{het} \mathrm{weten-}$ schappelijk onderzoek. Hoewel de WHO de faciliteiten van de primaire labora toria voor deelname aan het WHO-netwerk heeft helpen opbouwen en uitbreiden, heeft de transmationale werkverdeling tussen de laboratoria de verschillen tussen de primaire en de secundaire laboratoria niet werkleind. 260 De WHO heeft deze ontwikkeling in de verhouding tussen de primaire en de securdaire laboratoria niet gewild. Het is een onverwacht resultaat van de verbindingen in het netwerk. 
De richting warin het WHO-netwerk zich ontwikkeld is het resultaat wan talloze bestlissingen die in het proces van registreren los van elkaar lijken te staan (bilvoorbeeld de opzet van de agenda en de keuze voor de LANL database). Tegelikertijd is het niet geheel toevallig dat in de ontwikkeling wan de registratie de antigene diversiteit ondergeschikt wordt aan de genetische diversiteit van HV. Er is reeds een bepaalde infrastructuur voor een bepaald soort onderzoek opgebouwd en daarom liggen bepaalde keuzen meer voor de hand dan andere.

\section{.4 Hoe technisch is de aanpak van de WHO?}

De WHO staat bekend als een technische en a-politieke organisatie. Regïstreren past daarbij. Deze studie beschrift wat registreren nu precies inhoudt en laa: zien dat registreren veel meer omvat dan het verzamelen van gegevens. Ten eerste is het verzamelen van gegevens een te beperkte omschrijwing van het werk dat wordt verricht om tot gegevens te komen. Ten tweede heeft het proces van registreren effect op de ontwikkeling van onder andere kennis, beleid en verhoudingen. Er worden niet eerst gegevens verzameld en daarna pas beslissingen genomen of kennis ontwikkeld. Het registratieproces vormt de keuzen die beleidsmakers of wetenschappers kunnen maken. ${ }^{261}$ Registreren blijkt een vorm wan intervenièren. Deze conclusie werpt een ander perspectief op de WHO.

\section{Technischer dan technisch}

De WHO presenteert zich als een technische organisatie. Het technische beeld komt op alle manieren tot uitdrukking: in de taakomschrijving vam de WHO, de organisatiestructuur, de keuze van programma”, de geschiedenis die over de WHO wordt geschreven en zelfs in de kritiek op de organisatie (zie het eerste hoofdstuk). Het technische van de WHO heeft niet alleen betrekking op het soort activiteiten dat de organisatie onderneemt, maar ook op de rationele en instrumentele aanpak van problemen die zij woorstaat.262 Daarbij heeft technisch voor de WHO ook de betekenis van neutraal en a.politiek. Zolang de WHO zich beperkt tot technische zaken, hoeft zij geen partij te kiezen en kan zij haar onafhankelikkeid bewaren.

In het eerste hoofdstuk wordt de studie van Fenner over de wijze waarop de WHO de pokken heeft uitgebannen aangehaald als voorbeeld hoe de WHO zich profileert met technische activiteiten. ${ }^{263}$ Een belangrijk deel vam de studie wordt besteed aan de technische problemen die de WHO moest oplossen, zoals een volledige registratie van pokkenpatiënten en een betere distributie van vaccins over de wereld (zie hoofdstuk 1). Fenner beschrijft in zijn studie hoe door inschakeling van deskundigen en de opbouw wan voorzieningen voor onder andere de registratie van gegevens en de distributie wan vaccins problemen zijn opgelost. Hij beschriff echter niet welk werk en welk soort werk daarmee gemoeid is geweest.

Het technische van de WHO blijkt miet alleen te maken te hebben met de acti- 
viteiten waarmee de WHO zich wil profileren, maar wooral ook met het vele werk dat wordt verricht on die activiteiten te realiseren. Een duidelijk voorbeeld is de wijze warrop het projectvoorstel woor het WHO-netwerk wordt geschreven. De werkgroep heeft eerst een aantal conceptvoorstellen geschreven woordat een definitief voorstel aan de Stuurgroep voor vaccinontwikkeling wordt voorgelegd. In de verschillende versies van thet projectvoorstel verandert de inhoud van het plan nauwelijks; de opzet van het WHO-netwerk blifft hetzelfde. De tekst van het voorstel verandert wel. Het werk van het schrijven van een projectwoorstel bestaat voor een belangriik deel uit het herschrijven van de tekst van het voorstel.

Een tweede aspect walluit blijkt dat het werk van de WHO in zekere zin nog technischer is dam in het zelfbeeld naar woren kamt, heeft te maken met de wijze waarop veel beslissingen worden genomen. In het proces van registreren worden voortdurend praktische afwegingen gemaakt die sterk worden bepaald door de voorzieningen die reeds zijn opgebouwd. De primaire laboratoria houden bij de selectie van de bloeddonoren niet alleen rekening met de risicogroep waartoe zij behoren of het stadium van hun ziekte, maar vooral met hun bereidheid mee te willen werken aan het onderzoek en de mogelijkheid on hum voor het onderzoek te blijven volgen. De keuze voor de database is een ander voorbeeld voor de wijze waarop de bestaande infrastructuur de ontwikkeling van de registratie bepaalt. 264 Het LANL heeft al een infrastructuur opgebouwd voor de registratie van gegevens over HIV en de WHO bespaart een hoop werk door daar gebruik van te maken. Zulke technische kwesties bepalen het verloop van het project.

Het werk van de WHO zoals het in deze studie naar voren komt, is kortom nog technischer dan in thet zelfbeeld van de WHO wardt gepresenteerd.

\section{De politiek van de WHO}

De WHO wil zich presenteren als een technische organisatie om te voorkomen dat zij - net als haar voorganger de gezondheidsorganisatie van de volkenbond - door internationale politieke conflicten wordit verlamd. De WHO wil hatar onafhankelijkheild bewaren en daarom beperkt zil haar beleid tot technische zaken. Volgens de WHO is een technische aanpak ook de enige manier om intemationale conflicten te doorbreken. Als gezondheidsvoorzieningen verbeteren, zullen de gezondheidsverschillen kleiner worden en zal de wereldorde stabieler zijn. 20 voorspelt de WHO.

Tegelijkertijd streeft de WHO naar internationale samenwerking tussen staten. ${ }^{265}$ Bovendien wil zij op deze manier bijdragen aan de vorming van een vreedzame wereldorde - een wereld zonder (gewapende) conflicten. De WHO heeft dus zeker wel een politieke doelstelling. In de wijze waarop de WHO internationale samenwerking vorm wil geven, denkt de WHO echter politieke keuzen te kunnen vermijden. Zo streeft de WHO naar consensus tussen lidstaten, want als zij hel met elkaar eens zijjn hoeft de WHO geen partij te kiezen. Uit het belang dat de WHO hecht aan consensus blijkt overigens dat de WHO zich wel degelijk bewust is van de politieke rol die zij vervult. Zij wil een politieke doelstelling bereiken zon. 
der politiek te bedriven. In deze sudie is niet zo zeer gekeken naar de doelstellingen van de WHO als wel naar het werk dat de WHO verricht. De vraag is niet wat wil de WHO, maar wat doet de WHO.

De WHO zegt te streven naar de ontwikkeling van consensus, maar dat blikt niet uit de wijze waarop de samenwerking tussen de laboratoria in het WHOnetwerk wordi worm gegeven. De laboratoria in het WHO-netwerk hebben verschillende disciplinaire achtergronden en komen uit alle delen van de wereld. Elk heeft een andere methode om HV te karakteriseren. In het WHO-netwerk bliven de laboratoria hun eigen methoden hanteren en worden er geen pogin. gen ondernomen om de methoden op welke manier dan ook te integreren. De enige overeenstemming die er is, is dat ef verschillende methoden om HIV te karakteriseren naast elkaar kunnen bestaan. De verschillen tussen de laboratoria worden niet weggenomen; ze worden juist in stand gehouden.

Voor de oniwikkeling van kennis kan het van belang zijn om verschillende perspectieven naast elkaar te zetten.26 Om de diversiteit in kennis optimaal te benutten is het dan wel van belang om voor elk perspectief evenveel aandacht te hebben. Het heeft weinig zin om aandacht te vragen voor verschillende perspectieven als bij voorbaat al voor een bepaald perspectief is gekozen. De WHO wil ook geen keuze maken voor een bepaald soort kennis; zij wil zowel de gene: tische als de antigene diversiteit van HIV in kaart brengen. De wijze waarop de WHO de registratie opzet, heeft wel als resultaat dat de antigeme diversiteit wordt gevormd naar de genetische diversiteit en daaraan ondergeschikt wordt gemaakt. Onbedaeld en onvoorzien reproduceert de WHO de bestaande, ongelijke verhoudingen tussen de laboratoria en verdwijnt de diversiteit in kennis over HIV. Resumerend, de oprichting van het WHO-netwerk resulteert niet in consensus tussen de betrokken laboratoria over de beste methode om HIV te karakteriseren, noch over welke eigenschappen van HIV de effectiviteit van vaccins verhinderen. Binnem het WHO-netwerk zijn de laboratoria niet gelijkwaardig aan elkaar. De bestaande verschillen tussen zowel de disciplines als de primaire en secundaire laboratoria worden in stand gehouden. In die zin slaagt de WHO er niet in om internationale samenwerking tussen de laboratoria te bevorderen. Er wordt wel samengewerkt, maar niet op basis van consensus en gelijkwaardigheid en dat is toch het doel waarna de WHO streeft.

In haar beleid wil de WHO de internationale rechten van het individurespecteren. In de praktijk werken de goede intenties van de WHO anders uit. Aan elke vrijwilliger die bloed geeft voor het onderzoek, moet expliciet toestemming worden gevraagd. De regels voor het vragen van toestemming zijn vastgelegd in internationale verdragen. De WHO onderschrifft die verdragen en handelt er ook naar. Er wordt een toestemmingsverklaring gebruikt die aan alle internationale afspraken voldoet. De vrijwilligers worden geïnformeerd over de opzet van anderzoek, de hoeveelheild bloed die wordt afgenomen en de mogelijke risico's daarvan. De WHO realiseert zich echter omvoldoende dat meedoen aan het onderzoek voor de vrijwilligers meer omvat dan het geven van bloed. Ten eerste zal de WHO een deel van de vrijwilligers later opnieuw benaderen voor een vervolg van dit onderzoek, maar mogelijk ook voor andere onderzoeken. Het feit dat de 
vrijwilligers geregistreerd zijn. maakt het namelik makkelijk om deze mensen voor een verwolgonderzoek te benaderen. Voor het registreren van de gegevens en het opnieuw benaderen, vraagt de WHO geen toestemming. Ten tweede isoleert de WHO de vrijwilligers van hun directe omgeving in haar streven om de uitslag van de HIV-test geheim te houden. Alleen de vrijwilliger krijgt de uitslag van de test te horen en wordt daarmee woor het dilemma geplatatst die uitslag wel of niet aan naasten bekend te maken. In de wize waarop de WHO bloedmonsters en andere gegevens voor onderzoek verzamelt, beïnvloedt de WHO de relaties op individueel niveau binnen een gemeenschap. Omdat de WHO zichzelf ziet als een intemationale organisatie die alleen contacten onderhoudt met lidstaten, realiseert de WHO zich onvoldoende hoe ver haar netwerk reikt en draagt zij geen zorg voor de individuele deelnemers van onderzoeken van de WHO.

Resumerend, critici vinden het beleid van de WHO te technisch. Het beeld van de WHO wordt nog technischer als het ook het eigenlijke werk van de WHO (zoals het vergaderen of het bouwen aan voorzieningen), dat in de analyses van de critici onbesproken blifft, in ogenschouw wordt genomen. De WHO is inderdaad een zeer technische organisatie. Toch is het werk van de WHO niet puur technisch. De WHO zegt vooral de faciliteiten te willen bieden voor de ontwikkeling van de registratie. Zij organiseent de vergaderingen en bouwt een infrastructuur op die het voor de laboratoria mogelijk maakt om materialen en resultaten uit te wisselen. De rol van dergelijke voorzieningen in de ontwikkeling wan de registratie blijkt echter groter dan gedacht: het zijn juist de technische voorzieningen die de inhoud van de database hebben gevormd. En thet zijn ook de technische voorzieningen die de verhoudingen tussen de wetenschappelijke disciplines bepalen. Daarmee krijgt thet technische werk van de WHO wel degelijk een politieke betekenis - zeker als ook gekeken wordt naar de ontwikkeling van de krachtsverschillen tussen de primaire en de secundaire laboratoria en tussen de WHO en de vrijwilligers. De WHO is een technische ên een politieke organisatie.

\section{.5 Een ander beeld van de WHO}

Hoewel de WHO zich niet aan haar eigen maatstaven van een technische en a* politieke organisatie blijkt te houden, moet er toch iets zijn dat voor haar pleit. De WHO bestaat ten slotte al meer dan viltig jaar. Vroegere internationale gezondheidsorganisaties als het Intemationale Bureau voor de Hygiene en de Gezondheidsorganisatie van de volkenbond hebben veel korter bestaan.267 In vergelijking met andere internationale VN organisaties wordt de WHO ook als één van de succesvolste beschouwd. Het succers van de WHO wordt dan afgemeten aan het aantal internationale standaarden die de organisatie heeft ont* wikkeld en de wereldwijde programma's die zij heeft opgezet (met het wereldwijde pokkenvaccinatieprogramma als het meest bekende). ${ }^{268}$ Zelfs de casus in 
deze studie - het WHO-netwerk - is in zekere zin een succes. Binnen het WHOnetwerk wordt dan wel geen consensus bereikt tussen de laboratoria, maar dat blikk ook helemaal niet nodig. De werkgroep slaagt er wel in om de laboratoria aan elkar te binden. Wat is de kracht van de WHO?

Om meer recht te kumnen doen aan de werkwijze van de WHO, is het nodig centrale veronderstellingen over haar functioneren anders te formuleren. Hel beleid van de WHO is gebaseerd op een aantal veronderstellingen (zie ook hoofdstuk 1):

1 Professionele consensus is de basis van het WHO-beleid;

2 In de ontwikkeling van international gezondheidsbeleid heeft de WHO lou ter een coordinerende en faciliterende rol;

3 Dit alles vindt plaats binnen de formele juridische en internationale politie ke kaders.

Aan de hand van de voorbeelden uit paragraaf vier, kunnen deze drie veronderstellingen worden bijgesteld. in paragraaf vier zijn de voorbeelden aangehaald om te laten zien hoe de WHO niet functioneert op de wijze die zij zelf verondersteld en daarom haar doelstellingen niet kan bereiken. Dezelfde voorbeelden kunnen ook laten zien hoe de WHO op een andere manier haar doelstellingen ten dele toch wel bereikt.

\section{Professionele consensus of organisatorische bindingen?}

De WHO beschouwt professionele consensus als de basis van haar beleid. Ten eerste hebben, volgens de WHO, de stafleden een stevige gemeenschappelijke basis omdat zij een soortgelijke opleiding hebben gehad en een vergelijkbare carrière hebben doorlopen. Daardoor kunnen zij gemakkelijker tot overeenstemming komen. Bovendien staan de stafleden van de WHO dan sterker als er kritiek komt op het beleid.269 Dankzij hun gemeenschappelijke professionele uitgangspunten kunnen zij de eventuele druk van lidstaten om voor politieke redenen het beleid te wizigen, beter weerstaan. De WHO gaat er vanuit dat de deskundigheid van haar stafleden of haar adviseurs het allerbelangrijkste is.270 De wilze waarop in het WHO-netwerk de verhouding tussen de secundaire laboratoria wordt gevormd, laat twee aspecten zien van de werkwijze van de WHO. Ten eerste blijk: professionele consensus geen voorwaarde voor internationale samenwerking. Ook zonder consensus over de beste methode om HIV te karakteriseren, kunnen de laboratoria samen de diversiteit van HIV in kaart brengen. Ten tweede is deskundigheid niet het allerbelangrijkste voor het beleid van de WH10. Deze studie laat zien hoe het organisatorische werk - de vergaderingen, rapporten en niet te vergeten de materiële infrastructuur - belangrijke verbindende elementen zijn in het WHOnetwerk. 27 Voor de ontwikkeling van het WHOnetwerk bliiken niet alleen de discussies tussen de leden van de werkgroep van belang, maai vooral ook hoe de discussies geordend worden. De orde van de vergaderingen, dat wil zeggen de wijze waarop de vergadering de bespreking van de verschillende methoden om HIV te karakteriseren structureert, blijkt minstens zo belangrijk woor de verhoudingen tussen de laboratoria als het feit dat 
de vertegenwoordigers wan de laboratoria met elkar spreken 272 De agenda van 20 n vergadering is éen wan de vele organisatorische bindingen die het gebrek aan consensus tussen de laboratoria opvangt. ${ }^{273}$

\section{Faciliteiten op de achter- of op de voorgrond?}

De WHO wil haar rol in de ontwikkeling van internationaal gezondheidsbeleid beperken tot faciliteren en coördineren. De WHO faciliteert de ontwikkeling van de HW-registratie door onder andere de vergaderingen te organiseren, verga derstukken te verspreiden en zorg te dragen voor de voorzieningen om het bloed te transporteren. Faciliteren is werk dat moet gebeuren anders komt het project niet van de grond. Het geeft geen inhoud aan het project - althans in de ogen van de WHO. De WHO coördineert het WHO-netwerk onder andere door de ver* tegenwoordigers van de laboratoria bij elkaar te brengen en er voor te zorgen dat alle gegevens van de wrijwilligers op een centrale plek worden verameld, opdat zij gecontroleerd en eventueel verbeterd kunnen warden. In deze taakopwatting is de rol van de WHO bij de ontwikkeling van de registratie beperkt tot het scheppen van de juiste voorwaarden.

De faciliteiten (denk aan de LANL database) bliken echter een bepalende rol te hebben gespeeld bij de vorming van de verhoudingen tussen de betrokken laboratoria - en daarmee ook voor de verhouding tussen de genetische en de antigene diversiteit. 274 Het lijkt van zo weinig belang hoe kennis over de diversiteit van HIV wordt verzameld - of nu een registratie wordt opgezet, dan wel een wetenschappelijk rapport wordt geschreven. Als dan voor registreren wordt gekozen lijkt dat nog de meest neutrale manier om kennis te verzamelen - zonder een theorie of zonder een model als uitgangspunt worden sec gegevens verzameld. De keuze om gegevens over HIV te gaan registreren zet echter bepaalde laboratoria in het WHO-netwerk op een voorsprong. Het is niet gebruikelijk in de wetenschap om de resultaten van onderzoek te publiceren in een database. Alleen in de moleculaire biologie wordt dat gedaan. De databases in de moleculaire biologie zijn onder andere opgezet omdat de redacties vam wetenschappelijke tijdschriften minder interesse hebben voor de eindeloze reeksen gegevens van moleculair biologen. 275 Dat nadeel blijkt in het WHO-netwerk een belangriik voordeel. Het LANL heeft reeds een uitgebreide infrastructuur apgebouwd woor de registratie van onderzoeksresultaten en door daar gebrulk van te maken denkt de werkgroep geld en tijd te besparen. Uit het oogpunt van efficièntie is het een goede beslissing tegelijkertijd draagt deze beslissing onbedoeld en onvoorzien bij tot het ondergeschikt maken van de antigene diversiteit aan de genetische diversiteit van HIV. In het licht van de doelstelling van de registratie om de genetische en de antigene diversiteit van HIV naast elkaar te zetten, was de beslissing om gebruik te maken van de voorzieningen van thet LANL misschien wel efficiënt maar niet effectief.

Het voorbeeld van de LANL-database laat zien dat de WHO een belangrijke troef in handen heeft om internationale verhoudingen te vormen. Dit keer heeft de WHO gebruik gemaakt van de infrastructuur van een andere organisatie. De WHO is zelf ook gespecialiseerd in de ontwikkeling van infrastructuren en andere voor- 
zieningen. Als de WHO de ontwikkeling van het WHO-netwerk, waarin de antigene diversileit van HIV ondergeschikt wordt gemaakt aan de genetische diversiteil had willen keren, had zil meer moeten investeren in computers, classificaties en had zil geen gebruik moeten maken van de bestaande voorzieningen. Dat is minder efficiènt - omdat dan nog meer tijd en geld moet worden besteed aan organisatorisich werk - maar gezien de doelstelling van het project wellicht wel effectiewer.

De WHO wordt gezien als een bureaucratische kolos - een organisatie van vergaderingen, commissies, procedures en papieren. Critici vragen zich af wat de daadkracht van 20 'n organisatie is. Deze studie laat juist het belang van het bureaucratische of organisatorische werk zien. Dankzij zulk werk is de WHO juist effectief. Het is best mogelijk dat de WHO beter kan functioneren als bepaalde procedures worden vereenvoudigd dan wel afgeschaft en er kan wellicht ook minder worden vergaderd, maar het zijn ook de elementen die de kracht van de WHO vormen. Zonder de vergaderingen, de procedures en de technische voorzieningen kan de WHO niet functioneren zoals zij dat doet en zou zij minder effectief zijn dan zij nu is.

\section{Internationaal of transmationaal?}

De WHO is een organisatie van staten; alleen staten kunnen lid worden van de organisatie. Bovendien staat de soevereiniteit van staten voorop binnen de WHO. De WHO wil geen gezondheidspragramma's opzetten in een land, zelfs geen advies geven, zonder de toestemming wav een nationale overheid. ${ }^{276}$ Voor het WHO-netwerk is dan ook toestemming gevraagd aan de overheden van de landen waar de bloedmonsters zijn verzameld. Omdat al het beleid wan de WHO via de nationale overheid moet lopen en niet rechtstreeks in de lidstaten kan worden geimplementeerd, staat -zo vinden de criticil - de WHO ver weg van de werkelijke problemen. Volgens hen komt van de moole plannen van de WHO weinig terecht omdat de weg van internationaal beleid via nationaal naar lokaal beleid te lang is. 277

In het $\mathrm{WHO}$-netwerk is wel toestemming gevraagd aan de overheid van Ruanda, Deganda, Brazillie en Thailand, maar niet door de WHO zelf. De nationale over. heden worden geinformeerd over het project en om medewerking gevraagd doar de primaire laboratoria. Voordat de nationale overheid om toestemming wordt gevraggd, zijn de laboratoria al bij het WHO-project betrokken. Met andere woorden, het zijn niet de nationale overheden maar de lokale laboratoria die de brug vormen tussen het internationale en nationale niveau. Het beleid van de WHO ontwikkelt zich niet altijd in de volgorde vam internationaal, nationaal naar lokaal beleid maar than zich ook in andere volgorden ontwikkelen, bijvoorbeeld van internationadl, lokaal naar nationaal beleid.278

Omdat nationale overheden worden beschouwd als een centrale en onmisbare schakel in de ontwikkeling van internationaal beleid, blijt onzichtbaar hoe orga. nisaties in de lidstaten en zelfs individuele burgers aan de WHO verbonden zijn. ${ }^{279}$ Het gaat daarbij niet alleen om de medewerkers van de WHO, maar ook om de mensen die aanraking komen met de WHO programma's. De WHO staat 
niet rechtstreeks in contact met de bloeddonoren, maar via hun gegevens die de laboratoria van hen bewaren worden zij voor verschillende WHO-projecten benaderd. Op deze manier raken zil aan de WHO verbonden. De verzamelde gegevens blijken een bindend element tussen de. WHO en de individuele burgers in een land.

Het feit dat de WHO een internationale organisatie is, sluit transnationale relaties binnen de WHO niet uit.280 Het WHO-netwerk lat zien hoe binnen een internationale organisatie transmationale netwerken worden apgebouwd. Als de WHO niet kan zien welke transnationale relaties binnen haar programma"s zich ontwikkelen, dan kan de WHO voor die relaties ook geen zorg dragen. De WHO wil de vrijwilligers een vrije keus laten om mee te doen aan het onderzoek, maar onbedoeid en onwoorzien bindt zij de vrijwilligers juist voor langere tijd aan onderzoek. Om te kurnen werken binnen de intermationale verhoudingen en intermationale rechten, moet de WHO aandacht hebben voor transmationale relaties.

De WHO is een krachtige netwerkbouwer.28I Sinds haar eerste succes met de uitbanning van de pokken heeft de WHO zich steeds verder bekwaamd in het opbouwen van wereldwijde infrastructuren. Deze infrastructurele voorzieningen hebben net als telecommunicatie- en vervaermiddelen bijgedragen aan de vorming van transmationale relaties. ${ }^{282}$ De infrastructurele voorzieningen zijn echter niet alleen wegen waarlangs geneesmiddelen, kennis of bloedmonsters over de hele wereld kunnen worden uitgewisseld. Infrastructurele voorzieningen zijn ook

op andere manieren bindende elementen in de intemationale of transnationale gezondheidszorg. Het gebrek aan consensus tussen de betrokken wetenschappers wordt ondervangen door de infrastructurele voorzieningen die laboratoria aan elkaar binden. ${ }^{283}$ Het zijn kortom de infrastructurele voorzieningen die de WHO maken tot een transnationale organisatie die kennispolitiek bedrifft.

\section{.6 De toekomst van de WHO}

Het vijftig jarig bestaan van de WHO in 1998 is aangegrepen om de opzet en het functioneren van deze internationale gezondheidsorganisatie kritisch te bezien. Hoewel de WHO wordt gezien als éen van de best functionerende organisaties van de verenigde Naties, is er ook veel kritiek op de WHO. De WHO is, zo vinden de critici, uitgegroeid tot een logge bureaucratie. De kritiek op de bureaucratie wordt gevoed door twijfels over de twee belangrijkste uitgangspunten wan de WHO. De eerste is de centrale rol die lidstaten worden verondersteld te spelen in de ontwikkeling vam internationaal beleid en intenationale samenwerking. De tweede is de betekenis die de WHO hecht an de ontwikkeling van kennis en de opbouw van technische voorzieningen voor de oplassing van gezondheidsproblemen.

In de kritiek lijkt het alsof de WHO vast wil houden aan vervlogen idealen. Die WHO is echter wel degelijk meegegaan met de tijd en heeft haar werwachtingen 
ten aanzien wan internationale samenwerking en wetenschappelijke vooruitgang bifgesteld. De organisatiestructuur van de WHO veronderstelt dan wel een wereld die is opgedeeld in staten, mar tegelikertijd gat de WHO ook formele samenwerkingsrelaties aan met non-gouvernementele organisaties, steden of onderzoeksinstituten. ${ }^{284}$ De WHO is bovendien anders gaan denken over wat de beste danpak van gezondheidsproblemen is. Een louter medische aanpak van gezondheidsproblemen wordt ook door de WHO als te eenzijdig beschouwd. Medische kennis en techniek biliken niet altijd een oplossing te zijn voor gezondheids. problemen, zoals de bestrijing van aids heeft laten zien. De WHO hanteent een zeer brede en vooruitstrevende definitie van gezondheid. Gezondheid is meer dan de afwezigheid van ziekte, het is fysiek, sociaal en psychisch welbevinden.285 In beleidsprogramma's als "Gezonde Steden" of "Primary Health Care" wordt deze betekenis vari gezondheid geconcretiseerd door determinanten wan gezondheid te benoemen die buiten het terrein van de gezondheidszorg liggen, zoals armoede, milieu en scholing. ${ }^{286}$

Tegelijkertijd houdt de WHO wel vast aan het beeld van een internationale technische organisatie. Hoewel de WHO samenwerkingsrelaties heeft met non-gouvernementele organisaties en wereldwijde netwerken van onderzoekers of steden opzet, kunnen alleen staten lid worden van de WHO. De wraag of ook transmationale organisaties lid kunnen worden van de WHO is en blifft onbespreekbaar. Daarnaast will de WHO haar beleid in de toekomst nog verder inperken tot technische taken. Het "Gezonde Steden" programma en "Primary Health Care" werden al niet gezien als centrale activiteiten van de WHO, maar worden nog minder belangrijk als de voorgestelde reorganisatieplannen doorgang vinden. Dan worden registreren, standaardiseren en faciliterem de kerntaken van de WHO, net als in 1948 toen de WHO is opgericht. 287

Wat zou de beste strategie van de WHO voor de toekamst zijn? Hebben de critici die een meer politieke rol wan de WHO verwachten gelijk? Of heeft de WHO gelijk als zij wil vasthouden aan har technische aanpak van internationale gezondheidsproblemen? De critici vinden de technische aanpak van de WHO eenzijdig omdat daarin weinig aandacht is voor de politieke kant van gezondheidsbeleid (denk bijvoorbeeld aan de discussie over geboortebeperking).288 Deze studie bevestigt op dit punt hun kritiek. De WHO heeft inderdaad weinig aandacht voor cle mogelijke politieke implicaties van haar werk. Bij de wijze waarop de critici de politieke rol van de WHO worm willen geven, kunnen echter vraagtekens worden geplaatst. De critici zouden de WHO graag zien als een onathankelijk forum waar de partijen hun standpunten kumnen uitwisselen. Het WHO-netwerk kan gezten worden als zO'n onafhankeliik forum. De WHO nodigt verschillende deskundigen uit om rond te tafel te gaan zitten, ideeën uit te wisselen en zo samen tot een plan te komen voor de karakterisering van HIV. De werkgroep functioneert echter niet zo. Er wordt wel een gezamenlijk plan opgesteld, maar daarvoor wordt niet eerst naar consensus gezocht over controversiële issues die aan het project verbonden zijn, zoals de planning wan vaccin. studies en in relatie tot die studies de verhouding tussen de genetische en de antigene diwersiteilt van HIV. 
De politieke rol die de critici van de WHO vragen is te beperkt. Uit deze studle blijkt immers hoe de WHO ook op andere manieren politiek kan bedrijven.28\% Het is niet voldoende om alleen te kijken of en zo ja welke standpurten de WHO inneemt in politieke discussies. Zoals gezegd will de WHO zich beperken tot het faciliteren en coördineren van internationaal beleid op het gebied van de volksgezondheid. Deze studie laat zien hoe belangrijk de faciliteiten van de WHO zijn voor de ontwikkeling van het WHO-netwerk. De rol van dat soort voorzieningen blijkt een andere te zijn dan de WHO zelf denkt. De WHO zlet niet hoe de opbouw van de infrastructuur invloed heeft op de verhoudingen tussen de laboratoria. De politieke betekenis van de infrastructuur ontgaat haar.

Dankzij de inzet van twee theoretische kaders die in het eerste hoofdstuk zijn geintroduceerd, respectievelijk de figuratiesociologie en het wetenschapsonderzoek, maakt deze studie zichtbaar wat de WHO en de critici niet kunnen zien. De WHO en haar critici gaan er vanuit dat de technische voorzleningen van de WHO neutraal zijn, dat wil zeggen geen rol spelen in de ontwikkeling wan beleld, kennis en internationale verhoudingen. Wat zij niet zien is hoe technische voorzieningen een interventie met zich meedragen. De opbouw van technische voorzieningen kan miet los worden gezien van de inhoudelijke ontwikkeling van kennis, de keuzen die in beleid worden gemaakt en de vorming van internationale en transnationale verhoudingen.

De theoretische kaders waaruit deze studie is opgezet, gaan uit van ongebruikelijke veronderstellingen over respectievelijk de ontwikkeling van een wereldmaatschappij en wetenschappelijke kennis; het zijn veronderstellingen die ook haaks staan op dat waarvan de WHO zelf zegt uit te gaan. De WHO is een intermationale organisatie die moet opereren binnen strakke formele internationale politieke kaders. Door de organisatie eens vanuit een ander perspectief te onderzoeken, namelijk als een organisatie die transnationale netwerken opbouwt war. in de ontwikkeling van wettenschappelijke kennis is verweven met de vorming van international volksgezondheidsbeleid, worden nieuwe kenmerken van de organisatie zichtbaar. De materiële infrastructuur die de WHO wereldwijd heeft opgebouwd en al het organisatorische werk dat door de medewerkers van de WHO wordt verricht, blikt minstens zo veel inzicht te geven in het functioneren van de organisatie als de doelstellingen en de organisatiestructuur die al zo vaak zijn beschreven.

Door in deze studie de WHO te beschrijven ais eeri transmational an heterogeen netwerk, wordt de kracht van de organisatie zichtbaar. De WHO heeft meer invloed dan zij zelf denkt. Haar relaties reiken verder (de WHO is niet alleen verbonden met overheden maar ook met individuele onderzoekers en patienten in de verschillende landen), 290 Die relaties zijm ingrijpender voor zowel het functioneren van WHO, als woor het werk en leven van de betroklkenen. ${ }^{29 !}$ En ten slotte wormen die relaties een netwerk met een eigen dynamiek die het beleid richting geeft. De WHO overziet echter nu niet welke relaties met de technische voorzieningen worden opgebouwd en kan er dus ook geen zorg voordragen, laat staan invloed op uitoefenen.

In deze studie is wooral aandacht voor de werkwijze en de inspanningen van de 
WHO om tot resultaten te komen. De meeste studies naar de WHO zijn gericht op de resultaten van de organisatie: de ciffers, de standaarden, de woorzieningen en de programma's. De centrale vraag is meestal of en hoe de WHO haar doelstellingen bereikt en het succes van de organisatie wordt dan bepaald door resultaten af te meten aan de gestelde doeleinden. Latour heeft dit verschil in perspectief in zijn onderzoek naar de ontwikkeling van wetenschap aangeduid met het onderscheid in kant-en-klare wetenschap en wetenschap-in-actie (zie hoofdstuk 1).292 In deze studie zijin nu eens niet de kant-en-klare programma's van de WHO als uitgangspunt genomen, maar wordt de WHO-in-actie beschreven.

Een beschrijving van de WHO-in-actie geeft een rommeliger beeld wan de WHO dan de rationele en instrumentele aanpak die de WHO voorstaat en wil uitdragen (zie hoofdstuk 1): Er blijkt veel werk nodig te zijn om te kunnen registreren. Het is bovendien werk waar weinig eer alan valt te behalen, zoals wergaderen. het herschrijven van rapporten en het opbouwen van infrastructurele voorzieningen. Ook pakt dat werk nog al eens anders uit dan bedoeld. Allerlei praktische zaken die gaandeweg het project moeten worden opgelost, blijken achteraf belangrijke keuzemomenten te zijn geweest die niet als zodanig zijn herkent en daardoor ongemerkt voorbij zijn gegaan. Een gevolg daarvam is dat de doelstellingen van de HIV-registratie niet worden bereikt.

De gegeven analyse van het werk van de WHO in deze studie kan beschouwd worden als een deconstructie wan het zelfbeeld van de WHO. ZO'n deconstructie kan een averechts effect sorteren. Het doel van de studie is te laten zien houe de WHO met andere middelen politiek bedrifft. Een ontmaskering van het door de jaren heen zorgvuldig opgebouwde zelfbeeld van de WHO als een technische en a-politieke organisatie, kan het voor de WHO juist moeilijker maken om op haar manier politiek te bedrijven. Vasthouden aan het zelfbeeld kan immers een strategische zet zijn. De WHO doet alsof zij geen politieke doelstellingen heeft en zich louter wil richten op technische zaken, maar zelf weet ze well beter. Zolang het beeld van een technische en a-politieke organisatie overeind blift staan, kan de WHO ondertussen op haar eigen manier politiek gevoelige zaken regelen.293 De vraag is echter of het zelfbeeld van de WHO wel zo krachtig is.

Voor het WHO-netwerk geldt in ieder geval dat de doelstellingen van het project niet gehaald worden, omdat te weinig rekening is gehouden met de wijze waarop organisatorische en technische zaken ingrijpen op de inhoudelijke ontwikkeling van de registratie. Ongetwiffeld zullen de stafleden van de WHO strategieên hebben ontwikkeld om hun doeleinden te realiseren. Een 'slimme bureaucraat" die een nieuw beleid wil ontwikkelen, kiest bijvoorbeeld een titel woor het programma of de conferentie die past binnen het bestaamde beleid van de WHO om 20 discussies te vermijden. ${ }^{294}$ Dat stafleden van de WHO strategisch handelen en bureaucratische regels handig inzetten om hun doeleinden te bereiken, laat onverlet dat zij voortdurende onderscheid maken tussen technische en inhoudelijke zaken. Het zelfbeeld van de WHO dat uitgaat van een strikte scheiding tussen technische zaken en inhoudelije ontwikkelingen, heeft de werkgroep juist verblind. De vraag is of het vasthouden aan het beeld van een tech- 
nische en a-politieke organisatie een strategie van de WHO is en de WHO zich dus expres anders voordoet dan zij is.

In deze studie is een nieuw beeld van de WHO opgebouwd. Het is een positiex ver beeld dan de meeste critici van de organisatie schetsen. Een beschrijving van het werk van de WHO, zoals in deze studie is gegeven, laat zien welke inspanningen nodig zijn om tot gegevens te komen. Belangrijker is echter nog dat het werkproces van de WHO meer inzicht geeft in wat de WHO bereikt dan een vergelijking tussen de doelstellingen van de organisatie en de resultaten. In deze studie is in detail beschreven welk netwerk wordt opgebouwd om gegevens te verzamelen. Door de ontwikkelingen in het netwerk te volgen, wordt zichtbaar hoe de WHO diverse transnationale relaties opbouwt en onderhoudt.2\% Tegelijkertijd is duidelijk geworden hoe de voorzieningem van de WHO een stempel drukken op de verhoudingen tussen disciplines en de inhoud van kennis over HIV. ${ }^{297}$ De WHO blijkt naast een actor in het globaliseringsproces ook een producent van wetenschappelijke kennis. 
Noten

- Brink 1996, p. 73 .

2 - In 1977 neemc de World Health Assembly (WHA) het bestut om gezien het grote antal gezondheidsproblemen en die ongelike werdeling van de midelen aver de wereld om de gezcondheid wan mensen te verbeteren. de strategle wan de organisatie bij te stellen. Het doel van de organisate en haat lidstaren word: om de gezondheid wan alle mensen op het niveau te brengen waibbil zil sociali en economisch productief kiunnen functioneren. Aangezien de WHA het jaar 2000 als streefutum heft gesteld, heef deze strat togite de mam "Health for All by the year 2000" gekregen (W/HA, 1977).

4 - Er zijn in de loop der tijd wele beschouwingen werschenen over het functioneren van de WHO. De meeste studies naar de WHO richten zich op een bepaaid aspect (internationalisering, juridische regehingen) of een bepaald programma (bijwoorbeeld over de verschilfiende waccinatieprogramma's van de WHO). Godtee en Peabody hebben een algemenere kritiek op het functioneren van de WHO geformuleerd en darom noem hik linen apare. Godlee heef cussen nowember 1994 en mart 1995 een reeks ancikelen gepubliceerd in her British Medical Journal warin zij de kritiek die op de WHO bestaat an een nadere analyse onderwerpt. De vraag die in deze artikelen centraal staat is: wat heeft de WHO in de laats te decennia bereikt en warom heeft de WHO minder bereikt dan verwacht? Zle Goudlee, 1994a, 1994b, 1994c,1994d, 1995a, 19950, 1995c, 1995d. Peabody heeft de

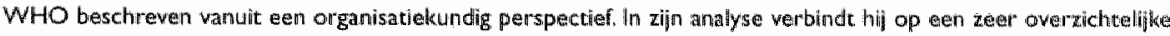
wijze de doelstellingen van de WHO ałn de organisatiestruccuur, de keuze van programma's en de cultuur van de orgamtsatic. Zie Peabody. 1995.

5 Zie Peabody, 1995 .

6 - Finckle en Crane, 1976, p. 369.

7 - De (beleids-) weronderstelling dat de verbetering van voorzieningen zal bijdangen aan de politieke stabiliteit is niet uniek voor de WHO. Het is een algemene weronderstelling die ten grondislag ligt an de optichting van de Verenigde Naties. Voor een uitgebreide bespreking van de veronderstelde relatie tussen enerzij|ds sociaal economische omstandigheden en anderzijds politieke stabiliteit zie Rivlin 1995.

5. Naar aarleiding van de aanhoudende kritielk op het functionenen van de WHO, gecombineerd met financiele problemen, zijn een aantal woorsteilen geschreven voor een andere opzet wan de organisutio wn and ander

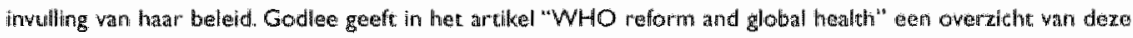
plannen (1997).

- In het weterschapsonderzoek, een disciplinte war deze studie sterk op leunt en die in paragrabl vier vafi dic

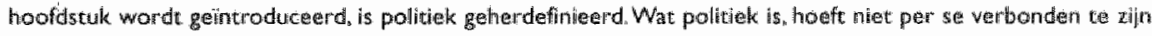
met bulangen of de vertegenwoordigers van die belangen, maar kan ook de vorm aannemen wan wen bepathde

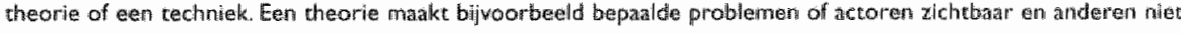
(zie Mal, 1996) in een techaiek kunnen brepalde sociale verhoudingen zijn ingeschrewen (zie Akrich, 1995 of Ploeg, 1998$)$.

10 - Zie Sterky (e.a., 1996 ; Frenk, 1995 en Godlee, 1997.

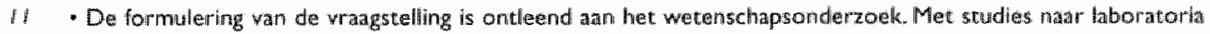
hebben onder andere Latour. Woolgar en KnorrwCetma, en na hen vele anderen, de aandacht gevestigd op de praktijk van wetenschappeligk onderzoek. De wetenschapstilosofie ten de wetenschapssociologite heeft zich tot het eind wan de jaren zeventig wooral gericht op de bestudering van de producten van wetenschappelifk onderzock, in her bijzonder op kennis. Door de vraag te stellen hoe die kernis tou stand komt. afwewel wat wetenschappers doen, is in het wetenschapsionderzoek een nieuw perspectief op wetenschappeligh kennis. ontwikkeld. Zlo vour een overzicht wan het onderzoek naar wetenschappelijke praktij|ken Pickering. 1992. De wragen utu het

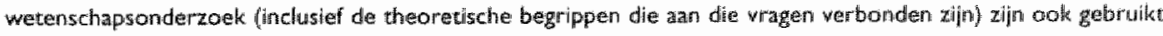
om andere praktijken te onderzoeken, zoals de ontwikkeling van techniek (Bijken tan Law, 1992) wen de rol van ethiek in de gezondhediszorg (De Vries 1993). 
- Hathing heft Gboratoriumexperimenten onderzocht on meer inziche te krigen in de ontwikkeling van

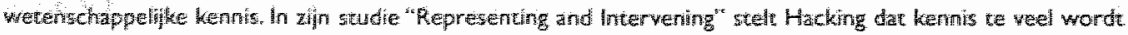
verboncten aan denken en theorie en te weinig: aan interyenieren en handelen. Kennis vergaren wordt daardoor

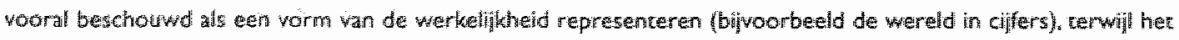
ontwikkelen wan kewh ook gezlen kith worden als een worm wan intervenieren, Als voorbeeld geef Hacking hoe

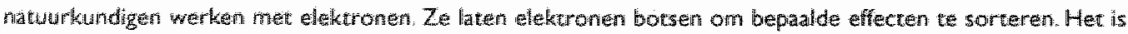

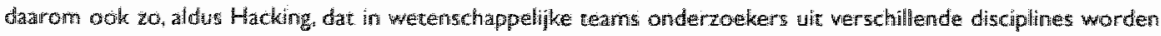

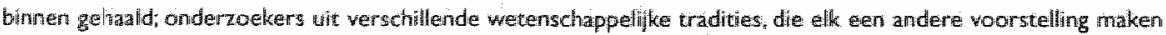
van hat object dat onderzotht wondt, kunnen andere dingen met het object van stwdie doen. Anders gezegd. onderzokkers wilk werschillende tradieies kunner werschillende effecten sorkeren. Hacking skelt daarmee representeren en intervenieren op een lijn. Dezie idecêten over kennis en representeren, zijh in her wetenschapsonderzoek door onder andere Latour verder aitgewerkt. Zie Hacking. 1983 en Latour. 1997.

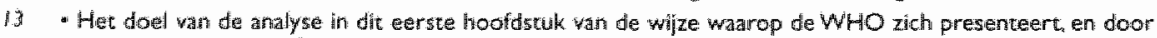
anderen wordt gepresenteded, is om unzicht te geven in wat de technische azhpak van gezondheidsproblemen dooi de WVHO onvat. Vanwege dit beperkte doel worden voor deze analyse geen primaire bronnen gebruike. De analyse wordt gebaseerd op secundair bronnenmaterial, dat wil zeggen op artikelen en andere documencen over de WHOV Vor een meer uigebreide anallyse wan de doelstellingen en aanpak wan de WWHO op basis van primaire bronnen werwijs ik naar Pannenborg, 1978.

14. Zir Pannenborg; 1978 en Peabody, 1995.

15 - De oprichtingsyerklaring wan de WHO is opgesteld en ondertekend op de internationale gezondheidgconferentie die van 19 juni tor 22 juni 1946 te Wew York werd gehouden. Op 7 april 1948 is de verklaring wan kracht gegaan (Officiat Recond World Health Organization, 2, 100). Pannienborg (1978) bespreekr de oprichtingtverklaring van o WHO titvoerig in zijn studie.

16 "Zie Rivilin, 1995.

17 - Zie Rivin, 1995 en lyyons, 1995.

$18 \cdot$ Lyons, 1995, p. 191.

19 - Hoewel thet idee van de maakbartheid van de samenleving is losgetaten, en overheden zich op allerlei betelusterreinen willen terugtrekken, is de wragg of de invloed vain nationale owerheden op de samenleving minder wordt in discussies over de priwarisering van de gezondheidszorg wordt duldelijk lhoe overheden weliswaar geen ambiticuze beleidsprogramma's meer maken mec de bäjbehorende blauwdrukken woor de inricheing van de gezondheidszorg, maar dat overheden via andere instrumenten zoals productieafspraken en het stellen wan randwoomwarden wellicht meer en zeker niet mincter invloed hebben gekregen op thet matschappelijk lewen (zie Clarcke en Newman, 1997). Het punt dat de rol van de owerheid (c.q. staat) is weranderd, of in ieder geval de manier watrop overheden maatschappelijke veranderingen willen bewerkstellingen, blift echter overeind staan.

20 - Zie Lyons, 1995.

21 - Om de bestrijding van aids aan te pakken wrerkt de WHO samen met zowel andere orgarsisaties van de Verenigde Naties als met non-gouverthementele organisaties (zie Gordenker, 1995). Een ander woorbeeld is het gezonde sitadenbeleid van de WHO. Kickbusch heeft samen met Quick in kart gebrach welke nieuwe actoren in

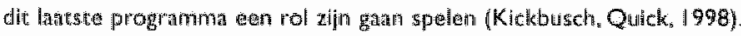

22. Zife Godlee. 1997 in vergeliking met Pannenborg. 1978

23 - Peabody, 1995, p.734.

24 - WHOn 1988, p. 5.

25 - Poabody, 1995.

26 - Dit uikgangspunt van de WHO over the belang vam de verspreiding van kentis woor een betere gezondheldszorg, komt duidelijk naar voren in de wijze warop de WHO zelf de geschiedenis van het Yaws programma hefit beschreven (tie W/HO, 1988),

$27 . \mathrm{WinO} 1988$.

28 - In bijna alle studies natr de WHO wordt meestal zonder enige reflectie het onderscheid dat de WHO mak tussen enerzijds deskumdigen en anderzijes politieke wertegenwoordigers owergenomen en benadrukt. Zie onder andere Finckle en Crane, 1976; Goodinan, 1971: Haws, 1990; Pannenborg, 1978.

29 - Peabody; 1995, p. 733.

30 -Jacobson. 1973, p. 179.

31 - Fenner: 1988.

32 - In de studic van Fenrer over het pokkenwaccinarieprogramma worden de genoemde kemmerken van de ziekte an het vaccin beschouwd als belangrike factoren die thet programma tot een succes hebben gemaakt. Dezelfde factoren zouden, aldus Fenner, tewens verklaren waron het malatia of het gele koortsprogramma, die hetzelfde doel hadden namelitk de uitroeing van de ziekte, minder succesvol zịnn geweest. Fenner leidt daaruit, geheel in de lijn wan de aitgangspunten van de $\mathrm{WHO}$, af dat de technische mogelijkheden orm ziekten te bestrijden, moeten 
worden verbeter (Fenner, 1988).

3 - Fenner; 1989

34. Fenver 1988 .

35 - Fenner, 1988.

36 - Fenner, 1988

37 - Zle WHO/ Uinice (1978):

38. Finckle en Crane hebben de standpunten die de WHO tussen 1952 an 1974 heoft ingenomen ten wanzien wan geboortebeperking nawwkeur in in kaart gebracht om te taten zien hoe de nomen vam de organisatie de beshirvorming ower dic politiek gevolig onderwerp hebben gevormd. Hun pun is dat wretenschappelinke kenhis eigenligk een geringe rol speel in de bestultworming wan de WHO. Bepallend woor de belleidskieuzen die de WHO makt, zijn wolgems hen, de nadruk die wordt gelegd op een rechnische oplossing van problemen. Zle Finckle en Clrane 1976.

39 - Zle Kammen, 2000.

40 - Zie Peabody 1995.

41 - Godlee, 1994, p. 1430.

42 - Knorr-Cetina heeft de vraag waarmee het wetenschapsonderzovik ooit begon namelijk wellke effecten he eft wetemschap op de samenlewing, geherformuleerd. On de rol van wetenschap in de samenleving te onderzoeken, zo is haar stelling, dient niet alleen gekeken te worden naar de ontwilkeling van keisnis maar ook naar de.

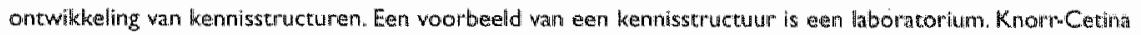
introduceert het laboratorium als een model om onganisaties te onderzoeken. De concepten en modellon uit de organisatiekunde, zoals bi|lvoorbeeld de professionele bureatucratie zijn volgens Knorr-Cetina te beperkt om

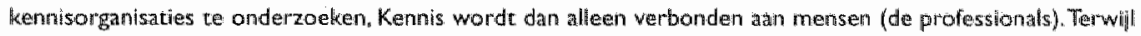
kennis ook genesteld is in de instrumenten of de materiele infrastructuur: Om die reden kumen kennisorganisaries. wolgens Knorr-Cetina beter als laboratoria worden onderzocht. De concepten die in de laboratoriumstudies zijn ontwikkeld, bieden daarvoor annknopingspunten (Knorp-Cetina, 1997).

43 - Globalisering is in eetste instantie voornamelijk bekeken als een economische ontwilkeling met aandacht voor de rol van internationale ondernemingen en wereldwide geldstromen. Geleidelijk is er" meer" aandach gekomen woor de politieke, saciale en culturele aspecten van globalisming. Hoewel globaltseping wanuit verschitlende perspectiven is onderzacht die ellk andere aspecten van deze ontwikkeling belichtert, is er well een centraal element in de discussie ce anderscheiden، mamelijk de aandache voor het groeiend aantal afhankelijkheidsrelaties cussen mensem, organisaties en landen. In bilna elke definitie van globalisering stat de toenemende afhamkelikkheid centraal. Zo ook in de definitis die Heilbran en Wilterdink geven van globalisering (Heilbron an Wilterdink, 1995). - Zoals gezegd is het proces van globalisering vanuit diverse perspectieven onderzocht In deze studie bepentk ik mil tot de politieke, sociale en culcurele aspecten van giobalisering. De intronductie die in de volgende paragrat wordt gegeven op het globaliseringsdebat is voornamelik gebaseend op sociologische en cultureel antropologische studies. De keuze woor deze disciplines heef enerzijds te maken met de wratgstelling wan maijn studie en anderzijds met de theoretische achtergrond van die vraagstelling, In deze studie wondt de technische aampak van de WHO aan een inader onderzoek onderworpen om na can of en hoe de WHO invloed heoft op de ontwikkeling wan wheterschappelikke kennis, de vorming wan betheid en de gertese van (internatonale)

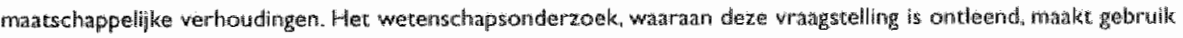
van sociologische en culurele antropologische methoden en concepten. Uit het globaliseringgedebar afln die studies geselectederd die aanshiten bil deze theoretische uitgangspunter wan het wetemschapsonderzook en die wooral op een microsociologisch niweau de effecten van globalisering willen tracieren. Woor een brede overzichtstudie naar het proces van globalisering verwijs ik u nat Castells (1996).

- Ritzer. 1993.

46 - Featherstone geeft een owerzichth wan studies naar de globalisenting valh cultuur. Featherstone pleic er voor om het onderzoek natr het proces van globalisering te richten op de verplatsing en uitwisseling van goederth, mengen, informatie, kennis en beelden. Featherstone is met nam geinteresseend in de wrag hoe door zullke processen nieuwe culturen ontstaan. Deze zogenamande derde culturen zijn zowel globaal, ondati zij het resultaat

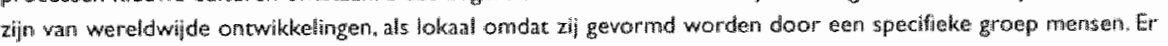

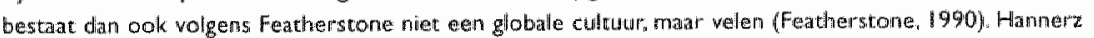
beschrijt én zoin globale (en tegelikkertifl lokale) cultuwr wan wertegenwoordigers wan grote ondernemingen dice de wereld over reizen. Waar deze mensen ook komen, ze logeren en eten in dezelfdie hotelketens en ontmoeten dezelfde mensen (hun collegavertegenwoordigersy. De wertegenwoordigers ztim weraldburgers, ze reizen de hele wereld over, maar tegelijkertijd leven zij in een heel keine wereid die verbonden is a an internationale howelketens en luchthavens (Hamnerz, 1990). De Swaan heeft op basis wan de studies van onder andere Featherstone en Hannerz een theoretisch perspectief ontwikkeld woor onderzoek nata de trangrationale samenleving Volgents de Swaan is het onderzoek in de sociologie te veel gekleund door de nationale context watrbinnen het onderzoek ts 


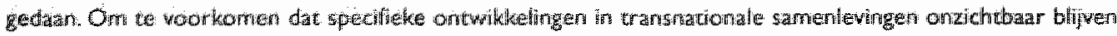
omdat het model van de rationale stat voor orderzok natr samentevingen niet wordt los gelaten, dienen

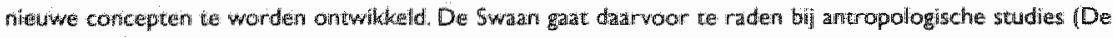
Sivician, 1995 .

47 "Empiriche studies naar de verspreiding wan weelat westersw producten zols de velevisie of cola zin een reace op meer theorecische studies natar onder andere kapicatiserng of Amerikanisering. Appadurail geef een overziche

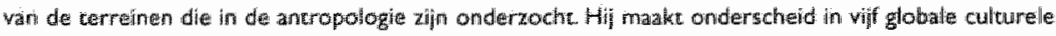

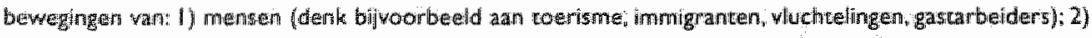

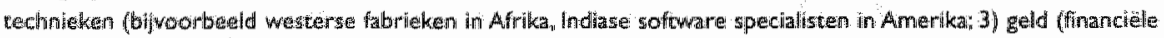

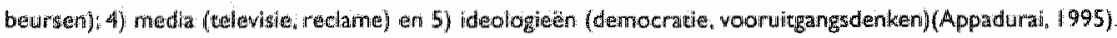

46 " Howet 1995

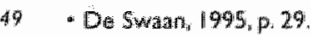

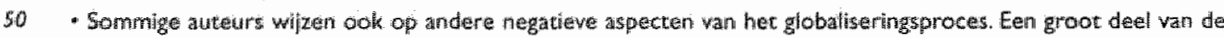

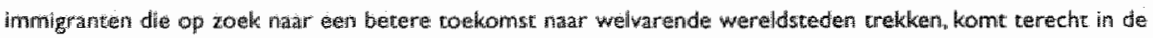

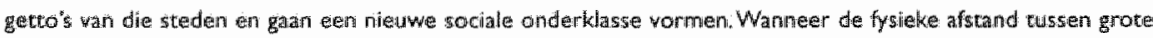
welvalut en en diepe armoede steeds kleiner wordt, kunnem sociale verhoudingen polariseiren. Zie Steenbergen. 1996.

51 - Anderson neemit emigranten in de zeventieryde eeuw als voorbeeld en De Swan de artistjeke, academische en aristocratische ellites in de zeventiende en achtrevde eeuw (Anderson, 1994, De Swatan, 1995).

s2. De snelle groei van het aancal onderwerpen op de agendas wan de intermationale organisaties en de ontwhkeling van meer algenueen beleid naar specifieks internationale operaties geeft Gordenker als reden woof de intensievere samenwerking tussen intermationale organisaties wan de Verenigde Naties met nongoulwernemervele organisaties. Non*gourvernementele organisaties worden door internationale organisaities geconsulteend als experts op een bepald terrein (Gondenker, 1995a).

53. Dit is mede her resultat van de antropologisthe en sociologische studies naar de bewegingen van mensen:

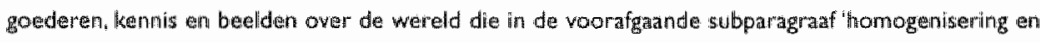
hybridisering" zijin azangehaald.

54 Hamnerz, 1996, p.6. Hoewel het concept "transmationaal' nog in ontwikkeling' is, komen de definities die varn dit concept worden gegeven sterk overeen. De definitie die bipwoorbeeld Featherstone (1990) en de Swan (19915) geven is bijna identiek aan die van Hanner.

55 - Zie De Swarn (1995) en Appadural (1990), die beiden een kort en helder owerzicht geven wan de diverse cranisnationale bewegingen.

56. De Swaam 1995. De Swan is een historisch sacioloog. Zlym perspectief op de ontwikkeling wan samenlewingen is gevormd door het werk van Elias (zie Elias (1971) en de Swaan (1996).

57 "Zie de inleiding die De Swaan theeft geschreven lin de sociologie "De mensenwetenschap" waarin hij het netwerkconcept uit de figuratiesociologie definieert en op heldere wijze toelicht (De Swaain, 1996).

58 - De Swam, 1995, P. 27.

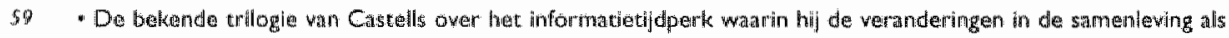

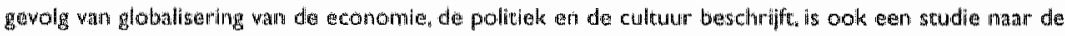

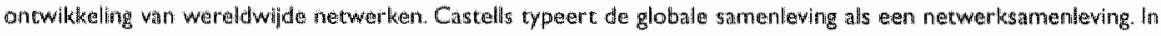
de huidige samerleving is, wolgens Castell, de plats in een netwerk (of juist het ontbreken van een plates in zen netwerk) afe batsis voor de mogelijkheden die iemand (of een organisatie) theeft om oncwikkelingen in de smmenleving te sturen. On twee redenen maak ik echter geen gebruik van de inzichten uît Cascells' scudie naar"

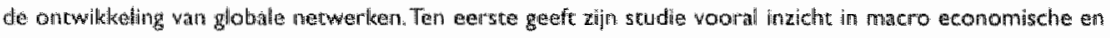
mactosocioliggische on wikthelimgen, terwifl deze studie zich richt op de interactie russen mensen en dimgan op een meer microsociologisch niweau. Jen tweede bouw Castells wort op een andere theoretische traditie thet

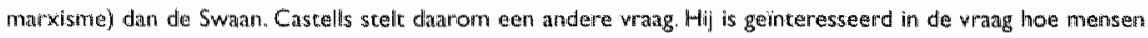
buten de wereldwijde netwerken worden gesloten. De Swaan stett juist de vragg hoe mensen op onverwachte manteren onderdegl worden yan wereldwijde netwerken. Die perspectieven zijn moeilitk te werrengen (zie het rinde wan paragraa 4 ).

60 - Anderson, 1983.

61. De 5waan.1995. De verbinding tussen emeizijds onderzok naar internationale organisaties en anderszijds tranenationale bewegingen wortt zelden gemaakt. Un het onderzoek naar de culturele en sociologische aspectern Yan globatiseing wil men afstand memen var eerdere studies nar internationalisering die vooral de rol van intermationale organisatie en mationale staten tot onderwerp hadden. Eerder genoemde auceurs zoals. Feacherstone, Appaturai an Hannerz zijn op zoek gegaan naar andere onderwerpen van studie om het proces van globalisering te onderzoeken (muiziek, reizen, etcetera). Het onderzoek naar internationale onganisaties heeft well nieuwe impulsen gekregen door het globaliseringsdebat, mar heeft een vrij beperkte inzet, weten de rol van 


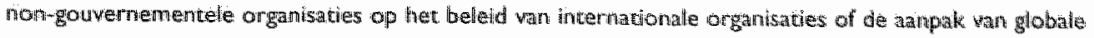

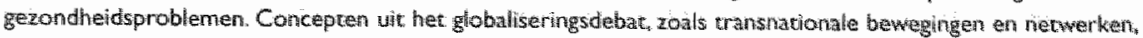

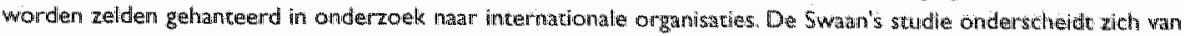

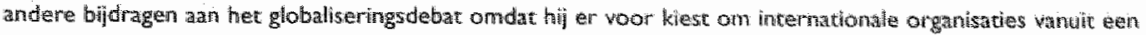

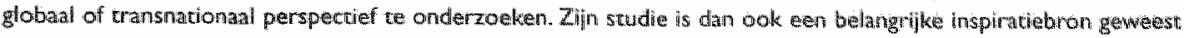
voor deze studie naar de WHO.

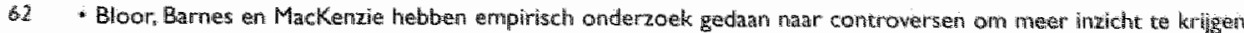
in de on wikkeling wan wetenschappelijke kennis: De wrag die aan hun werk ten grondslag higc is in hoeverre een sociologische analyse van de context (denk bijvoorbeeld aan dwhkatronen, handelswihze, beilangen en centrale doeleinden) warbinnen de controverse plats wind het wertoop wan die controverse kan vertwelderters. In tijn studie "Knowledge and Social Imagery" heeft Bloor die belangrijkste theoretische witgangspunten van weze controverse studiex (ook wel aangeduid met de sociologie wan weterschappeligke kennis of her Sterke Programma) uitgewerkt (Bloor, 1976). Een aantal belangriike empirische studies yan deze stroming in het wetenschapsonderzoek zjn te vinden in Bames en Shapin (1979) an Mackenzie (1981). Voor een algemene introductie in de wetenschapssociologie zie onder andere Boon (1989) en Hagendijk (1996).

- 3 - De bekendste laboratoriumstudie is die van Latour" en Woolgam (1979). Zie voor een owerzicht van de belangrijksta laboratorizumstudies Hagendiki 1996 ; Jasanoff, 1995 en Pickering 1992.

64. In het handboek van her weterschaps en techniek onderzoek (Jasanoff, I95) geeft Knor-Cetina een beschouwing over de laboratoriumstudies. Haar stelfing is dat de constnuctivistische benadering van wetenschap

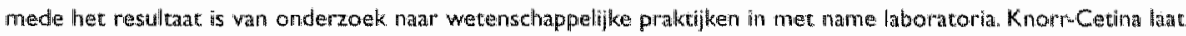
zien hoe de verandering van object van studie hn hat wetenschapsonderzoek wan kennis (al dan rihet un de vorm

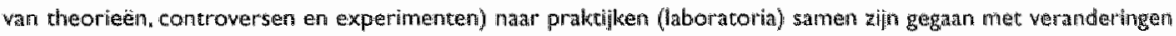
in de theoretische uilgangspunten wan het wetenschapsonderzoek. Zif geeft dawarmee rewens exn madene imwlling adn het begrip constructivisme: thet sleutelen aan (natululijke) elementen die wit bestande context worden gehaafd om met andere elementen te worden verbonden. Het voolbegld vath het wirus dat in deze alinea wordt aangehaald, is ook ontleend an dir overzichtsartikel van Knorm-Cetina.

65 - Latour heeft deze netwerkbenadering uigewerkt in ziln scudie Werenschap in Actie (1988b).

66. Hagendijk heeft het werk war Latour als nadicaal-constructivistasch geclassifficeend om een duidelijh onderseheid re maken met eerdiere constructivistische benaderingen als die van Bloor, Barnes en Mackenzie Terwill de vertegenwoordigers van het Sterke Programma de ontwikkeling van kennis willen begrijpen met onderzoek naar de invloed wan matschappelike structuren en verhoudingen op de on wikkeling van kennis, wijzen Latour en Callon zo"n sociale verklaring af. In plaats van de maatschappli of de natuvir als verktaring in te roepen woor de ontwikkeling van kennis, is het volgens Latour de task van een wetenschapsonderzoeker om wanuit de opbouw van wetenschappelijke nerwerken de oncwikkeling van matschappij en natuur te beschwijwen. Latour maakr geen onderscheid tussen kennis en de wereld waarop die kennis betrekking heeft. De wetenschap en de samenleving ontwikkelen zich, zo is zijn stelling, gelijktijdig. Anders gezegd, de ontwikkeling van kennis staat gelijk atan de

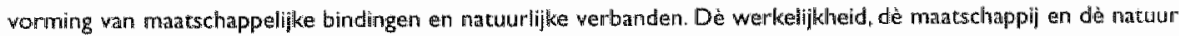

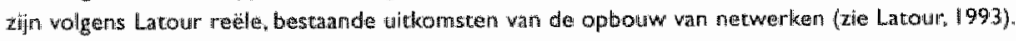

or Zle Latour 1988b.

* Zie Latour" 19806 .

69 - Latour. 19886.

70 - Dir voorbeeld is onvieend aan De viries, 1995

71 - Bowker en Star, 199\%.

72 - Zie Kickbush, Leeuw (1999); Leeuw, Kickbush, (1999), Yach, Bieticher, (1999a, 1999b).

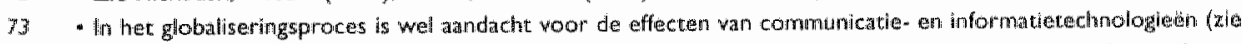
Anderson 1992. Castells, 1996). De ontwikkeling wan wetenschap en techniek bläfe echter onderbelicht. De Swaten geeft een woorbeold uir de wetenschappelike praktijk, mar gat verder niet in op de sprecifeke kenmerken van wetenschappelijke netwerken. Hij gebruike de reizen die geleevden in de negentiende eew al malken als woorbeelut om te laten zilen dat internationale contacten al eender bestonden dan vaak wordź gredachn (De Swan, (1995).

76. Andere woorbeelden zijn de studie wan Karm Bisterveld natr discussies ower vetoudering in thedertand en de

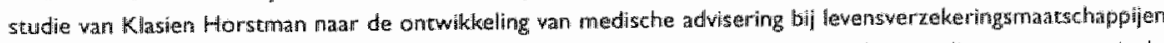
(Bisterveld, 1996, Horstman, 1996) Woor een bespreking ower de wijze warap iru deze studies concepten uit de sociologie naast concepten uht het wetenschapsonderzoek zijn gebruikt, zie Harber"s (1998).

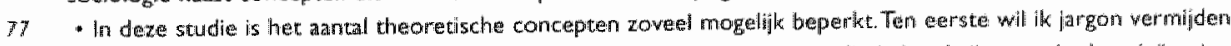
om de studie breder roegankelitk te maken dan alleen woor onderzoekers die bekend xijn met de theorieer vie 


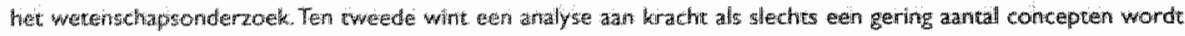
gebruht ondat dan de beperkingen yan die concepten (en van de analyse) beter zichubar worden.

70. De Swant 1996.

79 - Latour 198\%.

$60-Z$ Ban 1998 .

a) Zie Bowher en Star, 1999

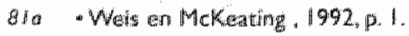

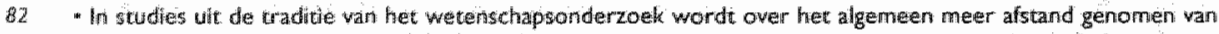
de apecifieke onderzoekswrager van een tusciptine waardoor de verschillen tussen de disciplimes scherper worden Mergezec De hitorische studies nasar de ontwiklkeling van disciplines die worden geschreven door

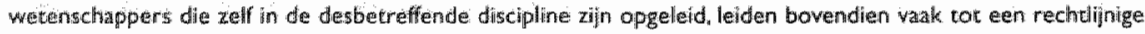
kijk op het verfeden en geven daram een eenijdg perspectief op de discipline (voor een kritische reflectie op disciptinggeschiedenissen, zire De Willde (19920).

83. Zire Bal die op dit punt een vergellijkng heeft gemakt thisten een wetenschappelijk en een beleidsdomein (Bal. (998).

64. Jasanoff (1995j heeft het gebruilk wan wetenschappelijke kenuis voor beleidsadviezen geproblematiseerd. Zi wist onder andere op dev verschillen in de wijze warop in enerzijds beleudsteksten en anderszifds wetenschappelikue artikelen onzekerhedien omtrent bestande kennis worden gepiresenteend. Dit punc worth verder uitgewerkt in paragraf drie wan dit hoofidstuk.

85 - Zü Koenis, 1997 .

86. Dexe arialyse wan de rol die registratiesystemten hebben gespeeld in de ontoleking van AIDS is gebaseerd op de studie wan Shilts (1987) nar de why watep tussen 1980 en 1985 op de eerste $z$ ilktegevallen van wat later de ziekte AIDS zou gaan heten, is gereageend door onder andere beleidsmalkers en wetenschappers.

- Z7e Shilts, 1987 . In mijn artikel 'Ciffers maken de wereld' is deze analyse werder uitgewerkt (De Bont, 1993).

- Ziga Oppentheirner, 1992.

89 - Verschillende historici hebben de ontdekking wan ADS (en HIV) beschrewehn ln deze paragraaf baseer ik mi] voomamelijk op het werk van Fee, Oppenheimet en Shilts. De reden waarom woor deze studies is gekozen is de

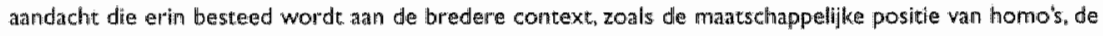
wetenschappelijke discussies in die tijd, de inrichring van de gezondheidszorg, etcetera. In plaats van de ziekte aids te beschouwen als een natuurifik gegewer, laten deze auteuirs zien hoe de ziekte in de loop der tijd op verschillende mawienen is gedefinieerd en hoe die verschillende definzies verbonden zijn geweest an Warschillende manierem om de zlekte te bestrijden.

90 - Over ther algemeen wordt aids gezien als exm infectieziekte zoals de polken, matr" Fee en Fox pleiten er woo" on aids op de eerste plats te beschouwen als een chronische ziekte. Dankzij de ontwikkeling van nieuwe geneesmiddelen, zo betogen Fee en Fox, zullen HV-geinffecteerden (althanis in Europa en de Verenigde Statem) steeds langer biliven leven. Net als bil chronische zieken zullen zij echter voortdurende onder behnandeling moeten bljjven en zullen zij waarschijnlijlk niet genezen. Een chronische ziekre stelt een overheid, volgens Fee en

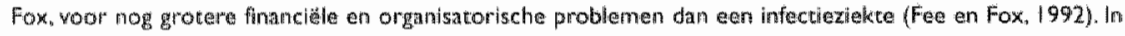

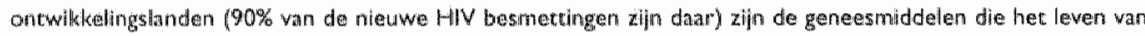
Hivergeinfecteerden kurnen vertengen echter miet voothanden. De kans dat daar alds een chronische ziekte wordt, is woralsnog klein. Om die reden wordt in dere studie aids als wen infectiezinelikte beschouwd.

91 - Moone, 1993, p. 313.

92 - Wand 1988 zijn diwerse overzichtsartikelen werschenwen waurin de (mogelijke) problemen bij de ontwikkelling vam HW-vaccins worden beschreven. Zie Fiucit en Hïschinger, 1988; Koff en Hoth, 1988; Girard, 1991; Hilleman, 1992; Karzon, 1992i Esparza. Heyward en Osmanovi 1996.

93. - Zle Connor en Kingman, 1988.

94. Zle voor oen introductie in de immunologie en de werking van vaccins, Van Tweel, 1993.

$95 \cdot$ Zie Kewles en Hood, 1992.

96 - Zle Grawley, 1993 .

a) - Zie Kewles en Hood, 1992.

93 - Zie Moore, 1994.

99 - De generische diversiteit van thet poliovilus werd pas bekend nadat een vaccin reeds was ontwilkkeld (zie Patul, (971).

100 - In de wersehillende overzichtartikelem over de problemen bij de ontwikikeling van effectieve HIY-vaccins wordt de genewische diversiteit wan HIV als eèn van de belangrihkste problemen beschouwd. Zie Fauci, en Fischinger; 1988; Koff en Hoth, 1988: Girard, 1991; Hilleman, 1992: Karzon 1992, Esparza eri Heymond en Osmonow, 1996. Deze onderzoekers beschriven dezelfde problemen, maar wegen de problemen verschillend en komen met andere oplossingen (zie de volgende subaparagraaf). 
102. - Zue Koff en Hoth, 1981.

103 - Zie Karzon, Bolognesi er Koff 1992.

104 - Moore, 1994, 5.313.

105 - Hilleman (1992) stam op dit standpunt.

100 - Fauci en Fischinger verdedigen dit standpunve.

107 - Zie Coten, $1992 a$

108: Zie Oppenheimer, 1992

109 - WHO/GPA, 1990, 3.3.

110 - Moore 1994, pi 313 .

il " Jasanof 1990.

112 - Shackley, Wynne, 1996.

II3 - WHOIGPABMMR, 1989, P. 2.

It - Zie Koenis, 1997

115 - Godlee, $\$ 994 \mathrm{c}$, p. 568 .

116 - Gaudilliere (1995) geett in zijn paper "How do weak bonds stick. Genetic diamoses becween the labonatory and the clinic", een soortgelijke analyse van te vergaderingen van kimische genetich en artsen. Volgents hem is de koppeling tussien genexische analyses en de preventie van ziekten het resuluat wah zulk "integrated regulatory

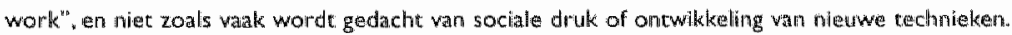

117 - Bradac $1992 \mathrm{~b}, \mathrm{p} .1$.

118 * Lacour spreekt in dit verband over positieve en negatieve modaliceiten. Positieve modaliteiten voeren ean uirsprak weg wan de lokale productieomstandigheden (het concrete, noeste werk in het hbormtorium) wan an wetensehappelike claim. Ze maken een uitsparak tot een feit. De nam yam de onderzoeker verthwijint biijwoorbeeld wit de telcst. Negateve modaliteiten voeren de claim van aen onderzoeker juist in de andere riclyting. terug naar her laboratorium, nat de lokale situatie. In her uiterste geval word de ooit algemeen geldende bewering, weer de louter persoonlijke opvatring van en indiwiduele onderzoeker (l.atcur, 1988b)

119 WHOIGPABMR, 1989, p. 2.

120 - WHORGPA, 1990, p. 3.

121 - WHOHGPANCU, $1992 \mathrm{~b}, \mathrm{p} .1$.

122 - WHOIGPANCU, 1994 , p. 1.

123 - Weis en McKeating , 1992, p. 1.

124. Zie Koenis, 1997.

125 "WHOIGPA, 1990, p. 7.

126 - Fenyo, $1992 \mathrm{a}$, p. 20.

127 - WHO/GPAIVCU $1992 \mathrm{~b}$, pi 3in

128 - Bowker (1997) heeft beschrewen hoe het bedriff Schlumberger er tussen 1920 en $1940 \mathrm{inslag}$ de om technieken te ontwikkelen waiamee onder de grond ollie kan wordien opgespoond. Dile technieken, zo claimt

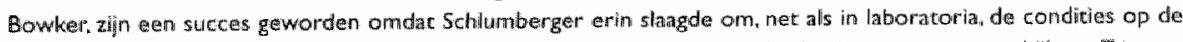

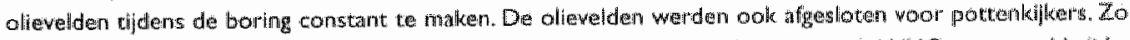

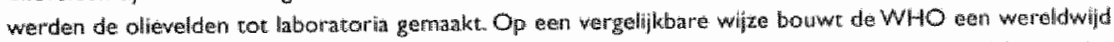
laboratorium door een inf astructutir op te zetten die het mogelajk maakt on winusen tussen laboratonat te transporteren.

130 . Epstein. 1994, p lino.

i31. Fernyo, 1992a. p. 1.

132. Het gebritilk van dezelfde monsters woor verschillende onderzoeken en dool" verschillende onderzoekers is miat unielk voor de WHO. Star en Griesemer (1989) hebben eerder beschreven hoe verschillende groeperi dict werschillende eisen aan materiaal stellen toch kumen sämenwerken. Als voorbeeld nemen zil de diener die voor een natuurhistorisch museum worden opgezer. De dieren worden zowel door wetenschappers als door teken gevangen genomen, gedood en opgezet. Zonder de inzet van leken kan het rouseum onvoldoende dieren verzamelen. De wijze waarop leken de dieren bewrerken, woldoet echten niet alngid jan de esen die da wetensichappers stellen. Om dit dilemma op te lossen ziljn er wolgens 5 tar en Griesemer een aantal mogellijkheden: 1. er wor den alleen minimumien gesteld aam de verzamelde monsters:

2. worden verschillende monsters werzameld zodat iedar kan kiezen wat hij nodig heefit voor zifin onderzoelc:

3. de monsters worden bewerkt zodat zil kunnen worden auagepasit an de ver"schillenda eisen die wort wh gesteld.

133 - Peabody. 1995, p. 732

134. Vergelijk Gaudiliere. 1995 en Koenis, 1997. 


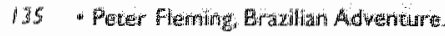

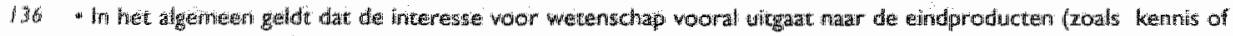

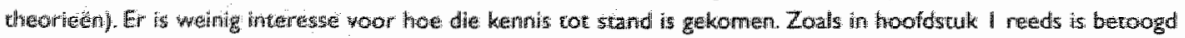

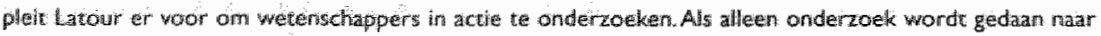

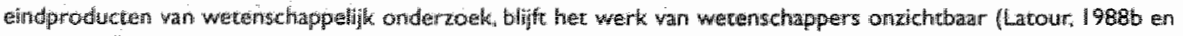

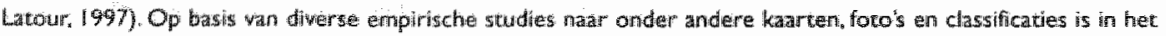
weterischapsonderzoel de fillosofische discussie over representadie in en ander perspectief geplatat. Daarbin ts de nadruk komen te liggen op de wele intermediairs tuss ben het object en de referent Representatie wordt

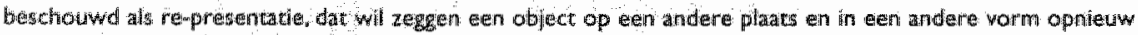

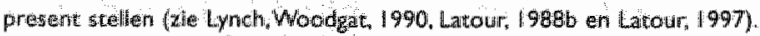

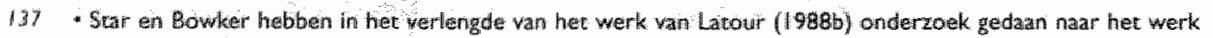

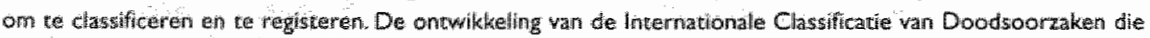

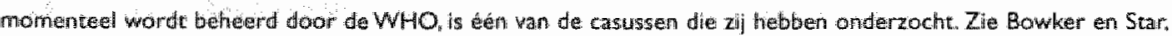
1999.

138 - In "Wetenschap in Acte bespreke Latour (1988b) en antal theoretische noties, zoals de genoemde concepten mobilseren; stabilswen en combineren, aan de hand warvan de ontwikkeling var statistische gegevens

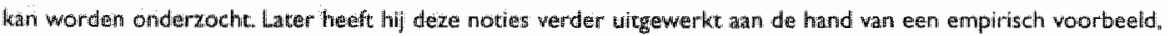
een registratie van bodemmonsters. Deze laatste studie "De Pedofélel van Boa Vista" is een belangrijke inspiratie gewerest woor de opzer war dir hooldstuk (Latour, 1997)

130 - Zhe Latour, 1997.

140 - Zie Latour, $1988 \mathrm{~b}$.

441 - Vergeliak Latour, 1997.

142 - Zije Gmerts. 1990.

143 - Farmer (exa) 1993.

144 - Zie Piwnik. 1993.

145 - Vergelijk Latour. 19886 . Wetenschappelifke kennis ondersetheide zich volgens Latour van andere soorten kennis door de vale bondgenoten dice wetenschappers an hun uttspraken weten te verbinden. De ene wetenschappelijke uitspraak werbergt een reeks vain andere wetenschappelijke uitspraken. Orn die redery noemt Latour de knooppunger van het netwerk versterkingen.

$14 B$ - Matho 1990, p. 5

447 - Sempala, 1993,p.1.

148 -Zie Esparza, 1991.

140 - Zie Esparza, 1994.

150 "WHOKGPA, 1990

151 "O'Connel (1993) geeft een voorbeld wah een onderzoek warvoor wel mensen langs verschiliende laboratoria zijn gestuurd. Om een instrument te cesten waarmee her vetpercentage wan sporters kan worden gemeten zijn een aancal mensen laboratorlía afgereisd waar het instrument wordt gebruikt. Tijdens het onderzoek hobben de proefpersonen een zorgvuldig deet gevoligd on en lichansgewicht constant te houden. $O^{\prime}$ Connels beschrlving wan dit onderzoek latt goed zhen hoe ingewilkkeld het zou zin om HWheinfecteerden langs de laboratorita te sturen. Hoe kan er bifwoorbeeld voon gezorgd worden dit de HIVinfectie van de proefpersonen nich tijidens het onderzoek niet: yerder ontwikkeld?

152. Vorgelink Latrour. 1997.

15.3 - Zio Plwhtk. 1993.

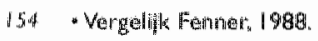

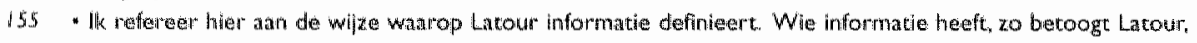
heeft de vorm wan lers in hamden: yonther het ding zelf. De winst van informatie verzamelen is, alldus Latour dat de: "vormen" van de dingen (dat klninen monsters, platjes, katarten of cijfers zilin) op éëry plaats bij elkaar kunnen worden gebractut Op die śne plats wordt de accumblatue en combinatie van vormen mogelijk (en morden kennisnetwerken opgebouwd), Zie Latour $1988 \mathrm{~b}$.

150 - Volgens Bowker en Stai ( 1999$)$ is de onwikkeling vary de Internationale registratie van Doodsoomakem, mede gevoind door de geringe interesse van artsen voor de registrate van de gegevens. De formulieren waarop artsen de doodscoonzatk dienen in te wuten, zijn zo kort en zo simpel magetikk gehouden.

157 * Fenyo, 1992, p. 15.

150 *WHO, 1988. p. 8.

159 -Zie Weniger, 1994.

160 "Meyers 1992 a. p. 2.

161 .WHO/GPAOAfice of Reseanch, 1992, annex 2, p. 1.

162 Wergeijot Latour: 1997. 
163 - Weniger, 1994

164 "Zie WHOKGPANCU 1994

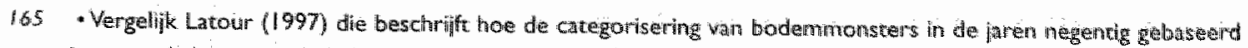
is op reeds lang gevescigde botanische chassificaties utite thegentiende evw

166. Vergelijk Oppenheimen 1992.

167 - UIt WHOMGPANCU, 1994

168 WHOIGPA, 1990.

169 - Vergelijk Latour. 1988 b.

170 - Uit Fenyo, 1992.

$\| 71$ - Rubsamen-Waigmann, $1992 \mathrm{~d}$

172 - WHOHO, 1989, p.10.

173 -WHOVGPANCU, 1994.

174 - WHO, 1994.

175 Karita, 1993a.

176 - Zie WHOIGPANCU, 1994; Chantepoy, 1993; Dowing. 1993; Karita، 1993b)

177 - WHO. 1992, p. 3

$179 \cdot$ Downing 1993.

179 - WHO, 1992, p.

180 - Vergeinjk de onschrijuing die Latour geeft van het concept scabiliseren (1988b).

181 - Latour heeft dit als de winst van regiscraties benoemd (1988b).

182 "Vergelijh Lacour en Bastide " 1986.

183 * Zie Hilgartmer: 1995.

184. WHOIGPA, 1992, p. 2.

185 - WHOIGPA, 1992.

186. . WHO 1992c, p. 2.

187 - WHO 1992.

128 - WHO, 1992c, p 4.

189 -WHO 1992c, P. 4.

190 "Zie Ko ber. 1994 en WHOIGPANCU, 1992

191 - Zie Hiigartoner; 1995.

192 - WHO, 1992 (januari), P. II.

193 . WHOLGPAVCU, 1993, p. $_{19 .}$

194 - In de latste vergadering van de werkgroep die tot dowel heeft om de pilotstudle te evalueren statat aen woorstel woor een internationale classificatie van genotypen op de agenda (zie WHO/GPAMCU, 1993).

195 - WHO, 1994, p. 24.

196. Vergelikking Hacking (1992) die de vrang stelt hoe wetenschappelijke kenuts stabiliseert (en controverses worden beslecht). Zijn ancwoord op deze vragg is dar in wetenschappelijke experimenten theoriceen instrumenten

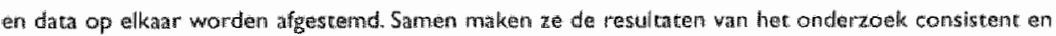
onweranderligk. Hacking noeme dat de self-vindication of labonatory stence (Uit: Plekering, 1992).

is + WHO, 1994, p. 24.

$198 \cdot$ WHO 1994.

199 - WHO. 1994. p. 39.

200 - Vergeliik Hacking 1992.

201 . Vergelifle Latour: 1997.

202 : Zie Meyers. 1992.

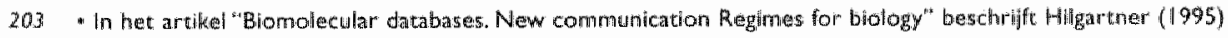
de ontwhllkeling en het gebruik van databases in de moleculaire biologie. Hil verbindt de opkomst wan deze dacabases met veranderingen in de wijze warop onderzoele wordt gedara in de moleculaire biologie.

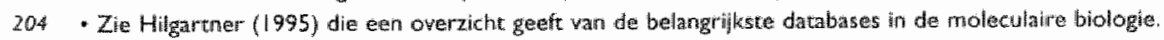

205 - Kevles en Hood, 1992.

206 "Zie Higartiner, 1995

207 - WHO, 1989, p. 13.

208 Korber, $1994, \mathrm{p} .1$.

209 - Belsey. 1992, p. 13.

210 - WHOIGPANCU 1994, bijlage 5. p. 2.

211 - Meyers, 1993. p. 3.

212 - WHOIGPA, 1990.

213 - Meyers, 1993, p. 3. 
- Heryer 1996,0

- Meyers, $150 \mathrm{z} ; \mathrm{p} .4$

- Metrers lgiga p.

- Vergellak Latour, 1997.

- WIOH/GPA, 1990

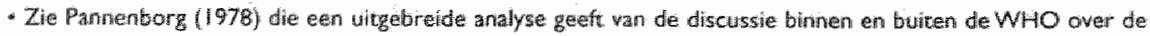

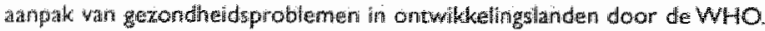

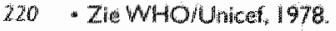

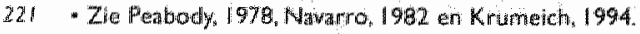

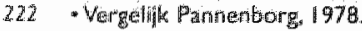

223 - De Swaris, 195, p. 32.

224 - Cont 1993

225 - WHOH, $1989, \mathrm{P}_{3} 3$

220. WHOKOA, 1990

227 MHOHOPANGU, 1994.

$228 \cdot \mathrm{W} 1 \mathrm{HO}, 1994,6 \mathrm{llag}$, $7, \mathrm{p}$

229 - Fenner, 1989.

230 - MHOKGPA, 1989

231 - WHOLGPANOffice of ResedrathCU. $1992 \mathrm{~b}$

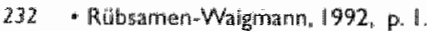

233 - WHOYGPAIVCU, 994.

234 - WHOMGPAVEU, 1994.

235 -WHOHGPANCU, 1994,atriex 2, p.3.

236 -WMIOIGPAVCU, 1994, annex 2. P. 4

23\% - WMOMGPANCU, 1994, annex 2. p. 4.

238 WHOnnetwork for HW Hsolations and chalracterization. (1994) HV type I Variacion in World Healuh

Organization-Sponsored Waccine Ewaluation Sices: Genetic Screening, Sequence Analysis, and Preliminary Biological

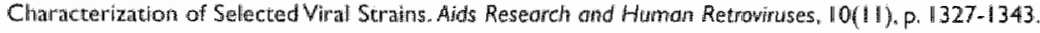

239 "Moore, 1994; Cohen, 1994.

240 - Esparza, 1991 en lesparza, 1996.

241 - Zie Leenen, 1991, annex 2

242 - Zie Chritakis (1988), Curie, Bishaw (e.a) (1994).

243 - Zile Epstein, 1994

244 Downing 1993; Chantepoy, 1993; Karital, 1993.

$245 \cdot$ Downing 1993.

246 - Zie Weniger 1994.

247 - Wenigeri 1994 , p. 1008.

248' - Downing, 1993.

$24 \% \cdot 2$ io Feischman, 1995.

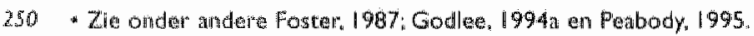

251 - Zile Findicle, 1987; Godled, 1994a en Peabody, 1995.

$25 \%$ - Zhe WHOIGPA, 1990

253" Vergelljk Bowker en 5tar (1999) die in hun studie nar onder andere de Internationale Classificatie van

Doodsoorzaken het werk om te chassificeren ten standaardiseren juigt wel zichtbaar hebben gemaakt.

25. Zie Lacour, 1988a en Knori-Cetina, 1995.

255 - De studie *an Bowker Star (1995) is zoals eerder opgemerkt een uinzondering.

250 - Vergelilik Gaudilliare. 1995.

257 . Vergelijlk Gaudiliere, 1995 wern Koentis. 1997.

258 - Vergelillth dit met de uitwerking die Bowker (1994) greeft van het concept infrastructural inwersion:

259 - ZM WHOM GPANCU. 1994.

260 - Vergelijk dit met de beschrijwing die Anderson (1992) geeft van de oncwikkeling van transnationale culturen die volgens hem mede het resultat zijn van de ontwikkeling van goedkopere en snellere transport- en cominumicatietrechnologieèn.

26. "Zie oolk de analyse van Anderson (1983) van wolksstellingen en de classificatie van bevolkingsgroepen die datatroor ziling gemaake.

262 - Zie Pabady, 1995

263 - Zire Fenner: 1988.

284 Vergelijlk met Bowken: 1994. 
Z6b - Zle Van Gunsteren (1994) die pleit voor mear diversiteit in beleid.

267 - Zhe Weindting 1995.

268 - Zue Peabody 1995.

269 - Zie Cox en Jacobson, 1974.

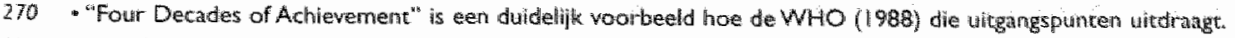

271 - Vergelik met Koenis (1997) en KnorinCetina (1995).

272 - Zije Lakour: $1988 b$.

273 - Zie ook Koenis 1997.

274 - Vergelialk mer Bowker, 1994.

275 - Zie Hilgartner. 1995.

276 - Ze Godlee, 1994d.

277 - Zie onder andere Godlee, 1994d en Peabody. 1995.

278 . De 5wan, 1995.

279 - Zie ook De Swaan, 1995.

280 - Zoalls in hoofdstuk I reeds is opgemerkt, beschouwt De Swaan (1995) intemationale prganisanes als de plek biul witstek om de ontwikkeling wan transnationale netwerken te onderzoeken.

281 - Vergelijk met Latour (1988b) die wetenschappers ziet als metwerkbouwers.

282 - Anderson, 1992.

283 - Zie Koenis, 1997.

284. Zie Kickibusch en Quick 1998.

285 - Zie WHO, 1947.

286 - Zie WHOHnicef, 1978.

287 - Zie Godlee, 1997.

288 - De genoemde woorbeelden zifn ondleend aan respectieveliflk Finckle en Crane (1978) en Godlee (1994:a).

289 - Vergelijir Latour, 1993

290 - Zie De Swaan (1995) waaraan dit punt onthleend is.

291 - Vergelijk met Latour $1988 \mathrm{~b}$.

292 - Zie Latour, $1988 \mathrm{~b}$.

293 - Züe Latour, 1993 en Wan der Ploeg (1998).

294 - Persoonlike mededeling yan Dr. de Leeuw, die werkzam is voor de WHO.

295 - Zoals onder andere Peabody (1995) betoogt.

296 - Zie De Swaun 1995.

297 "Zie ook Bowker, 1994. 
$\frac{L}{136}$ 


\section{Literatuur}

A

Ada, G. (e.a.)(1992). Hiv: to vaccinate or not to vaccinate. Nature, 359 (15 okton ber), p. 572 .

Akrich, M. (1992). The De-scription of Technical Objects, in: Bijker, W. en Law, J. (red.) (1992).

Anderson, B. (1983). Imagined Communities. Reflections on the origin and spre. ad of nationalism. Londen: Verso Editions/NLB.

Anderson, B. (1992). Long-distance nationalism. World capitalism and the rise of identity policy. Amsterdam: CASA.

Anderson, W., Jackson, M. en Gutmann Rosenkrantz, B. (1994). Towards an unnatural history of immunology. Joumal of the history of immunology, 27(3), p. 575594 .

Anomiem (1993). International Organizations. Theoretical Perspectives and Current Trends". International Social Science Joumal, 45, p. 4.

Armstrong, D. (1983). The political anatomy of the body. Medical Knowledge in Britain in the twentieth century. Cambridge: Cambridge University Press.

Appadurai, A. (1990). Disjuncture and Difference in the Global Cultural Economy. Theory, Culture and Society, 7, p. 295-310.

$\mathbf{B}$

Bal, R. (1998). Grenzenwerk. Over de organisatie wan normstelling voar de arbeidsplek. Enschede: Twente University Press.

Barnes, B., Shapin, S. (1979). Natural Order. Historical Studies of Scientific Cultures. Londen: Sage.

Beck, U. (1997). De wereld ais risicomaatschappij. Essays over de ecologische crisis en de politiek van de wooruitgang. Amsterdam: De Balie.

Berg, M. (1997). Rationalizing Medical Work. Decision-Support Techniques and Medical Practices. Cambridge: MIT Press.

Bloor, D. (1976). Knowledge and Social Imagery. Chicago: Chicago University Press.

Bont, A. de (1993). De ciffers maken de wereld. Signet, 10 (3), p. 7-9.

Boon, L en de Vries, G. (1995). Wetenschapsthearie. De empirische wending. Groningen: Wolters Noordhoff.

Bowker, G. (1994a). Science on the Run: Information Management and Industrial Geophysics at Schlumberger, 1920-1940. Landern: The MIT Press. 
Bowker, 6. en Star, L. (1994b). Knowledge and infrastructure in international information management: problems of classification and coding, in: Bud, L. (red.). Information Acumen. Londen: Routhledge.

Bowker, G., Star, L. (1999). Sorting things out. Classification and its consequences. Cambridge: MIT Press.

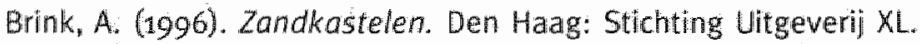

Burke; D. (1993). Vaccine therapy for HIV: A historical review of the treatment of infectious diseases by active specific immunization with microbe-derived antigens. Vaccine, $11(9)$, p. $883-891$.

Biker. W: (1990). The Social Construction of Technology. Dissertatie Maastricht. Biker, W., Law, 1. (1992). Shaping technology, Building Society. Studies in sociotechnical change. Cambridge: MIT Press.

Bijsterveld, K. (1996). Geen kwestie van leeftijd. Verzorgingsstaat, wetenschap en discussies rond ouderen in Nederland, 1945-1982. Amsterdam: Varn Gennep.

\section{C}

Callon, M., Law, I. Rip, A. (1986). Mapping the dynamics of science and tech. nology: Sociology of Science in de Real World. Houndsmills: Macmillan Press L.TD.

Cambrossio, A., Keating, P., Tauber, A. (1994). Introduction: Immunology as an historical object. Journal of the history of biology, 37 (3), p. 375-378.

Castells, M. (1996). The rise of the network society. Oxford: Blackwell.

Christakis, N. (1988). The ethical design of an aids vaccine trial in Africa. Hasting Center Report, p. 31-37.

Clarck, I., Newman, I. (1997). The Managerial State. Power, Politics and Ideology in the Remaking of Social Welfare. Londen: Sage.

Cohen, J. (1992a). Lobbying for an Aids Trial. Science, 258 (23 oktober), p. 536539 .

Cohen, 1. (1992b). Army Investigates Researchers's report of Clinical Trial Data. Science, 258 (6 november), p. $883-884$.

Cohen, 1. (1992C). MicroGeneSys Vaccine Trial Gets A Public Peer Review. Science, 258 (13 november), p. 1079-1080.

Cohen, 1. (1992d). Agencies Spar Over Vaccine Trial. Science, 259 ( 5 februari), p. $752-753$

Cohen, 1. (1994). U.S Panel Votes to Delay Real-World Vaccine Trials. Science, 264 (24 juni).

Cox, R. en lacobson, H. (red.)(1974). The anatomy of Influence: Decision-Making in Intemational Organizations. New Haven: Yale University Press.

Crawley, M. (red)(1993). Natural enemies. The population biology of predators, porasites and diseases. Oxford: Blackwell Scientific Publications.

Curie, P. (e.a.) (1994). Ethical, behavioural and social aspects of HIV vaccine trials in developing countries. JAMA, 27 (194), p. 295-301.

Daniel, H. en Parker, R. (1993). Sexuality, Politics and Aids in Brazil: in another 
world. Londen: Falmer Press.

Davis, J. (1990). Mapping the Code. The Human Geriome Project and the Choices of Modern Science. New York: logh Wiley \& Sons.

Dijk, I., van (1995). Reading the human genome narrative. Science as culture, 30, p. $217-247$.

E

Elias, N. (1971). Wat is saciologie? Utrecht: spectrum.

Epstein, H. (1994). HIV vaccins trials for Uganda? The Lancet, $343(9$ april), p. 910. Epstein, H. (1994). Fat. Granda, 49 (4), p. 132-170.

Epstein, 5. (1996). Impure Science: AlDS, Activism and the Politics of Knowledge. University of California Press.

Esparza, 1. (e.a.)(1991). Planning for HIV vaccine trials: The World Health Organization perspective. Aids, 5, 5159-\$163.

Esparza, 1. (e.a.). Vaccine briefing. Global AlDS news, 2, p. 5*7.

Esparza, .., (e.a.) (1996). HIV vaccine Development: from basic research to human trials. Aids, 10 (supplement A), S1 123-132.

Fackelmann, K. (1994). Large-Scale Aids Vaccine Test Delayed. Science News, 145. p. 404 .

Fardon, R. (red.) (1995). Countenworks. Londen: Routledge.

Farmer, P. (e.a.) (1993). Women, Poverty and Aids. An introduction. Culture, Medicine and Psychiatry, 17(4), p. 387-398.

Fauci, A. en Fishinger, M. (1988). The development of an aids vaccine: progress and promise. Public Health Reports, 103 (3), p. 230-236.

Featherstone, M. (red.) (1990). Global Culture: nationalism, globalization and modernity. Sage: Londen.

Fee, E. en Fax, M. (1988). Aids: The Burdens of History. Berkeley: University of Califomia Press.

Fee, E. en Fox, M. (1992). Aids: The making of a chronic disease. Berketey: University of California Press.

Fenner, F. (e.a)(1988). Smallpox and its Eradication. Genève: World Health Organization.

Finkle, F. en Crane, B. (1976). The World Health Organization and the population issue: organizational issues in the United Nations. Population and development review, 2 , p. $367-393$.

Fleischman, 1. (1995). Uganda: Living HIV positively. Africa Report, 40(3), p. 56 59 .

Foster, G. (1987). Bureaucratic aspects of international health agencies. Social Science and Medicine, 25 (9), p. 1039-1048.

Friendland, P. en Kedes, L. (1985). Discovering the secrets of DNA. Communication of the $A C M, 28(11)$, p. 1164-1187.

Frenk, J. (e.a.)(1997). The future of world health. The new world order and international health. British Medical Jourral, 314 (10 mei), p. 1404-1407. 
Gaudilière, ). (1995). How do weak bonds stick? Genetic diagnoses between the laboratory and the clinic. Een paper gepresenteard op het symposium "Human Genome Research, februari $1995^{* *}$, te Bristol.

Gigerenzer, G. (e.a) (1989). The empire of chance. How probability changed science and everyday life. Cambridge: Cambridge University Press.

Gmerk, M. (1990). History of AIDS. Emergence and origin of a modern pandemic. New Versey: Princeton University Press.

Girard, M. (1991). The Challenge of HIV vaccines. Vaccine, 9 (november), p. 781 790.

Godlee, F. (1993). WHO at the crossroads. Will it embrace the necessary reforms. British Medical Journal, 306 (1 meil), p. 1143-1144.

Godlee, F. (1994a). WHO in crisis. British Medical lowrnal, 309 (26 november), p. $1424-1428$.

Godlee, F. (1994b). WHO in retreat: is it losing its influence? British Medical Joumal, 309 (3 december), p. 1491-1495.

Godlee, F. (1994C). The regions - too much power, too little effect. Brifish Medical Journal, 309, p. 1566-1570.

Godlee, F. (1994d). WHO at country level - a little impact, no strategy. British Medical lournal, 309 (17 december), p. 1636-1639.

Godlee, F. (1995a). WHO fellowships - what do they achieve? British Medical Journal, 310 (14 januari), p. 110-112.

Godlee, F. (1995b). WHO's special programmes: undermining from above. British Medical Journal, 310 (21 januari), p. 178-182.

Gadlee, F. (1995C). WhO in Europe: does it have a role? British Medical laurnal, 310 (11 februari), p. 389-393.

Godlee, $F_{n}$ (1995d). Interview with the director general. British Medical Joumal, 310 (4 maart), p. $583-586$.

Godlee, $F_{4}(1996)$. New hope for WHO? Term limits and more formal application procedures may bring a change in leadership. Brtish Medical Journal, 312 (1 juni), p. 1276.

Godlee, F. (1997). WHO reform and global health. Radical restructuring is the only way ahead. British Medical Journal, 314 (10 mei), p. 1359 1360.

Goodman. N. (1971). International Health Organizations and Their Work. Edingburgh: Churchill Livingstone.

Gordenker, L. (1995a). UN at 50: institutional development. International Social Science Journal, 144 (2), p. 243-260.

Gordenker, L., Coate, R., Jomsson, C.en Soderholm, P. (1995b). International cooperation in response tot aids. Pinter: Londen.

Gunsteren, H., van (199.4). Culturen van besturen. Amsterdam: Boom.

Haas. E. (1990). When knowledge is power: Three madels of Change in International Organizations. Berkeley: University of California Press. 
Hacking, I. (1983). Representing and intervening. Introductory topics in the phi losophy of narural science. Cambridge: Cambridge University Press.

Hacking, I. (1990). The Taming of Chance. Cambridge: Cambridge University Press. Hacking, I. (1992). The Self-Vindication of the Laboratory Sciences. Uit: Pickering (1992).

Hagendijk, R. (1996). Wetenschap, Constructivisme en Cultuur. Amsterdam: Uitgeverij Luna Negra.

Hannerz, U. (1991). Scenarios for peripheral cultures, in King, A. (red.), Culture, Globalization and the World-System. Contemporary conditions for the representation of identity. Londen: MacMillan.

Harbers, H. (1998). Uncovered Boundaries: Historical Sociology and Actor Network Theory. Science, Technology and Human Values, 23(3), p.351-361.

Heilbron, J. en Wilterdink, N. (1995). Mondialisering. Inleiding. Amsterdams Socialogisch Tijdschrift, 22(1), p. 7-15.

Hendriks, R. (1995). De wetenschapsantropologie van Latour. Heerlerv: Open universiteit.

Hilgartner, S. (1995). Biomolecular databases. New communication Regimes for biology. Science Communication, 17 (2), p. $240-263$.

Hilleman, R. (1992). Impediments, imponderables and alternatives in the attempt to develop an effective vaccine against aids. Vaccine, 14 (10), p. 1053-1058.

Horstman, K. (1996). Verzekerd leven. Artsen en levenswerzekeringsmoatschappijen, 1880-1920. Amsterdam: Babylon-De Geus.

Howell, S. (1995). Whose knowledge and whose power? A new perspective on cultural diffusion, in: Fardon, R. (red.) (1995), p. 164-180.

Jasanaff, S. (1990). The fifth branch: Science Advisers as Policymakers. Cambridge: Harvard up.

Jasanoff, 5. (red.) (1995). Handbook of science and technology studies. Londen: Sage.

Jones, S. (1993). The Language of the genes. Londen: Flamingo.

Kammen, 1., van (1999). Representing User's Bodies: The Gendered Development of Anti-Fertility Vaccines. Science, Technology and Human Values, 24 (3), p. 307\% 338.

Kammen, \#. (2000). Conceiving Contraceptives. The Involvement of Users in AstiFertility Vaccines Development. Dissertatie Universiteit van Amsterdam.

Karita, E. (e.a) (1993a). HIV-infection among STD patients, Kigali, Rwanda 19881991. International Journal of STD \& AIDS, 4, p. 211-213.

Karzon, D. (e.a.) (1992). Development of vaccine for the prevention of aids, a critical appraisal. Vaccine, 10, p. 1039-1052.

Kevles, D., Hoad, L (1992). The Code of cades: scientific and social issues in the human genome project. Cambridge: Harvard University Press.

Kickbusch, 1. (1995). World Health Organisation: change and progress. British 
Medical Journal, 310 (10 junil. p. 1515-1520.

Kickbusch, 1., Quick, 1. (1998). Partnership for health in the 21st century. World Health Statistics Quartely, 51, p.68.74.

Kickbusch, I., De Leeuw, E. (1999). Global Public Health: revisting healthy public poilicy at the global level. Health Promation International, 14 (4), p. 285-288. King, A (red.) (1991), Culture, Glabalization and the World-System. Contemporary conditions for the representation of identity. Londen: MacMillan.

Knorr-Cetina, K. (1995). Laboratory Studies: The Cultural Approach to the Study of Science, in lasanoff, S. (red.) (1995).

Knorr-Cetina, K. (1997). De epistemiologische samenleving. Hoe kennisstructuren zich nestelen in sociale structuren. $k \& M$. Tijdschrift voor empirische filosofie, $1(2), p \cdot 5-28$.

Koenis, S. (1997). Het verlangen naar Gemeenschap. Over moraal en politiek in Nederland na de verzuiling. Amsterdam: Van Gennep.

Koff, W. en Hoth, D. (1988). Development and testing of alids vaccines. Science, 241 (22 juli), p. $426 \times 432$.

Krumeich, A. (1994). The Blessings of Motherhood. Health pregnancy and child care in Doninica. Amsterdam: Het Spinhuis.

L

Latour, B. en Woolgar, S. (1979). Laboratory Life. The Social Construction af Scientific Facts. Londen: Sage.

Latour, B. (1988a). The Pasteurization of France. Cambridge: Cambridge University Press.

Latour, B. (1988b). Wetenschap in Actie. Wetenschappers en technici in de maatschappij. Amsterdam: Uitgeverij Bert Bakker.

Latour, B. (1993). We have never been modern. New York: Harverster Wheatsheaf. Latour, B. (1997). De Berlinse sleutel en andere lessen van een liefhebber van weterschap en techniek. Amsterdam: Van Gennep.

Law, I. (1994). Organizing Modernity. Oxford: Blackwell publishers.

Leenen, H. (1991), Gezondheidsrecht voor opleidingen in de gezondheidszorg. Houten: Bohn, Stafleu, Van Loghum.

Leeuw, E., Kickbusch, I. (1999). Van 'international health' naar transnationale volksgezondheidsvraagstukken en 'global health'. TSG Tildschrift voor Gezondheidswetenschappen, 77 (3), p. $138-139$.

Lepage, P., Dabis, F., Hitimana, D.. Msellati, P., Van Goethen, C., Stevens, A., Nsengumurenyy, F., Buzubagira, A., Serufilira, A., De Clercq, A., Van de Perre, P. (1991). Perinatal transmission of HIV-1: lack of impact of maternal HIV infection on characteristics of livebirths and on neonatal mortality in Kigali, Rwanda. AlDS, 5 p. $295 \cdot 300$.

Lepage, P., Van de Perre, P., Msellati, P., Hitimana, D., Simonon, A., Van Goethem, C., Mukamabano, B., Karita, E. Stevens, A., Mathieu, R., Salamon, R. en Dabis, F. (1993). Mother-to-child Transmission of Human Immunodefieciency Virus Type 1 (HW-1) and Its Determinants: A cohort Study in Kigali, Rwanda. American Journol of Epidemiology, 137 (6), p. 589-599. 
Lynch, M., Woodgat, S. (red) (1990). Representation in Scientific Practice. Cambridge: MiT Press.

Lyons, G. (1995). Intraduction, International Social Science Joumal, $144(2), \mathrm{p}$. $191-195$.

M

Macilwain, C. (1993). MicroGeneSys drops out of NIH trial for Aids vaccine. Nature, 362 ( 25 maart), p. 277 .

Macilwain, C. (1994). HIV vaccines get the green light for Third World trials. Nature, 371 (20 oktober), p. 644.

Mackenzie (1981). Statistics in Britain, $1865-1930$. The Social Construction of Scientific Knowledge. Edingburgh: Edingburgh University Press.

Mol, A.p Mesman, I. (1996). Neonatal food and the politics of theory. Some questions of method. Social Studies of Science: an international review of research in the social dimensions of science and technology, 26 (2), p. 419-444. Moore, I. (e.a.)(1993). Which gp160 vaccine? Nature, 361(11 februari), p. 503.

Moore, I. en Anderson, R. (1994). The WHO and why of HIV vaccine trials. Noture, 372 (24 november). p. $313 \cdot 314$.

$\mathbf{N}$

Navarro, V. (red.)(1982). Imperialism, health and medicine. London: Pluto Press. Norton Wise, M. (1995). The Values of Precision. Princeton: Princeton University Press.

0'Connel, .. (1993). Meterology: The Creation of Universality by the Circulation of Particulars. Social Studies of Science, 23, p. 191-173.

Oppenheimer, G (1992). Causes, Cases and Cohorts, in: Fee, E. (red) (1992).

Oudshoorn, N. (1997). From Population Control Politics to Chemicals: The WHO as in Intermediary Organization in Contraceptive Development. Social Studies of Science, 1997 (1), p. 42-72.

Pannenborg, C. (1978). A new international health order. An inquiry into the international relations of the World Health Organization. Groningen: Davids Decor Ablasserdam.

Paul, J. (1971). A history of polio myelitis. New Haven: Yale University Press.

Paul, W. (1995). Reexamining AIDS Research Priorities. Science, 276 (3 februari), p. 633.636.

Peabody, 1. (1995). An organizational analysis of the world health organization: narrowing the gap between promise and performance. Social Science of Medicine, 40(6), p. 731-742.

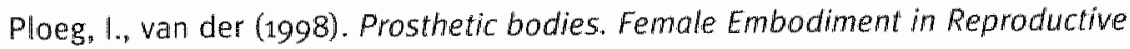
Technologies. Proefschrift Universiteit Maastricht.

Porter, T. (1995). Trust in numbers. The pursuit of objectivity in science and public 
life. Princeton: Princeton University Press.

Pickering. A. (1992). Science as practice and culture. Chicago: The University of Chicago Press.

Pivnik, A. (1993). HIV infection and the meaning of condoms. Culture, Medicine and Psychiatry, 17. p. 430442.

$\mathbf{R}$

Remberger, M. (1995). Beyond Nature and Culture: A note on Medicine in the Age of Molecular Biology. Sience in Context, 8(1), p. 249-263.

Ritzer, G. (1993). The MacDonalization of society: an investigation into the changing of contemporary social life. Thousands Oaks: Pine Forge Press.

Rivlin, B. (1995). Development dilemma's and tensions at the UN. International organizations, november, p. $333-345$.

5

Sald, E. (1992). Culture and Imperialisme. Londen: Vintage.

Santos, B., Beck, E., Peixoto, M., Kitchen, V., Weber, J. (1994). Changing patterns of HIV_1 transmission in Southem Brazil 1985-1991. International Journal of STD \& ADS, 5. p. 202-206.

Sawampanyalert, P., Unhchusak, K., Thanprasertsuk, S., Akarawesi, P. (1994). HIV1 seroconvesrion rates among female commercial sex workers, Chiang Mai, Thailand; a multi cross-sectional study. AlDS, 8(6), p. 825-828.

Shackley, S. en Wynne, B. (1996). Representing Uncertainty in Global Climate Change Science and Policy; Boundary-Ordering Devices and Authority. Science, Technology and Human Values, 21(3), p. 275-302.

Shilts, R. (1987). And the band played on. Politics, people and the aids epidemic. Londen: Penquin books.

Sklair, L. (1991). Sociology of the Global System. Baltimore: John Hopkins University Press.

Smith, R. (1995). The WHO: change or die. Reform must begin now but will depend on an new leader. British Medical Journal, 310 (4 maart), p. 542-544.

Smouts, M. (1995). Some thoughts on international organizations and theories of regulation, Intemational Organizations, November, p. 443-452.

Star, S. en Griesemer (1989). Institutional ecology, "translations" and boundary objects; amateurs and professionals in Berkeley's Museurn of Vertebrate Zoology, 1907-1939. Social Studies of Science, 19. p. 387-420.

Steenbergen, B, van. (1996). Globalization and the new inquality. Utrecht: Universiteit Utrecht.

Sterky, G., Bidwai, P., Trung, T., Childers, E., Chunharas, S., Dan, Y. et al (1996). Global. Health cooperation in the twenty-first century and the role of the UN system. Uppsalla: Dag Hammerskljold Foundation.

Stone, R. (1992). Uganda to Host Aids Vaccine Therapy Trials. Science, 257 (7 augustus).

Streefland, P. en Chabot, I. (red.)(1990). Implementing Health Care. The experiences since Alma Ata. Amsterdam: KIT. 
Swaan, A., de (1995). De sociologische studie wan de transnationale samenle. ving, Amsterdoms sociologisch ifidschrift, 22 (1), p. 16-35.

Swaan, A., de (1996). De mensenmaatschappij. Een inleiding. Amsterdam: Uitgeverij Bert Bakker.

$T$

Tweel, I., van (1993). Immunologie. Het menselijk afweersysteem. Maastricht: Natuur \& Techniek.

V

Volvovitz, F. en Smith, G. (1993). Properties of an HIV "vaccine'. Nature, 362, p. 504-505.

Vries, 6., de (1995). De ontwikkeling van wetenschap: een inleiding in de wetenschopsfilosofie. Groningen: Wolters-Noordhoff.

Vuijsje, H. (1992). Mens erger je niet. Privacybescherming en wetenschappelijk onderzoek. 's Gravenhagen: Sdu Grafische bediijven.

W

Ward, M. (1993). A different disease. HIV/Aids and health care for women in poverty. Culture, Medicine and Psychiatry, 17, P. 413-430.

Wawer, M., Sewankambo, N., Berkley, S., Serwadda, D., Msugrave, S., Gray, R., Musagara, M., Stallings, R., Knode-Lule, I. (1994). British Medical Journal, 308 (november), p. 171-173.

Weindling, P. (1995). International Health organisations and movements 1918 . 1939. Cambridge: Cambridge University Press.

Weniger, B. (1994). Experience from HIV incidence cohorts in Thailand: implications for HV vaccine efficacy trials. ANDS, 8, p. 1007-1010.

Wilde, $\mathrm{R}_{\mathrm{a}}$, de (1992). Discipline en legende. De identiteit van de sociologie in Duitsland en de Verenigde Staten, 1870-1930. Amsterdam: Van Gennep.

WHA (1977). Technical Cooperation. WHA30.43, 2*19 mei 1977. WHO: Genève.

WHO (1947). Preamble to the constitution of the Wartd Health Organization. Genêve: World Health Organization.

WHO (1988). Four Decades of Achievement. Genève: World Health Organization.

Yach, D. Bettcher, D. (1998a). The globalization of public health, 1. Threats and Oppertunities. American Journal of Public Health, 88(5), p. $735-738$.

Yach, D. Bettcher, D. (1998b). The globalization of public health II. The convergens of self-interest and altruism. American Journal of Public Health, 88(5), p. $738-741$. 
B

146 


\section{Bronnen}

\section{Verslagen van vergaderingen}

WHO/GPA/BMR (1989). Report of a technical working group on criteria for laboratory characterization of HIV isolates, 11-12 december, Genève.

WHO/GPA (1990). Report of a technical working group on the establishment of a WHO network for HIV isolation and characterization, 19-21 november, Potters Bar.

WHO/WHO network for HIV isolation and characterization (1992). Proposal for an international collaborative study on HW isolation and characterization (first draft). 13-15 januari 1992, Genève.

WHO/GPA/Vaccine development Unil / Technical Working Group on HIV isolation and characterization (1992). Initial characterization of HIV isolates from WHOsponsored vaccine evaluation sites (second draft), $13-15$ januari. Geneve.

WHO/GPA/Office of Research/Vaccine development Unit (1992). WHO network for HIV isolation and characterization. WHO sponsored international pilot study on HIV characterization. Prototype protocol for specimen collection and processing. Genève.

WHO/GPA (1992) Third Meeting of the Steering Committee on Vaccine development (first draft), $1-3$ june, Genève.

WHO/GPA/Office of research (1992b). Report of the meeting of Prinicipal Investigators of the WHO network for HIV isolation and characterization (a satellite meeting to the 8 th international Conference on AIDS. 19-24 july, Amsterdam), 18 augustus 1992.

WHO network for HIV isolation and characterization (1993). Report of an infor- 
mat discussion of preliminary results of an international pilotstudy on "initial characterization of HHW strains from WHO-sponsored HIV/aids vaccine evaluation sites", 22 maart 1993. Londen.

Meyers, 6. (1993). WHO working report (first draft), Los Alamos.

WHO/GPA/VCU (1994). Report of a meeting of principal investigators of the WHO network for HIV isolation and characterization (second draft). 6-8 september 1993. Genève.

\section{Vergaderstukken}

Allen, E. (1993). A list of sequences. Los Alamos National Laboratory.

Belsey, E. (1992). Trip Report HV sequence database and analysis project. Los Alamos National Laboratory, 24-25 maart 1992.

Bradac, 1. (1993). Report on the progess with the preparation of expanded viral stocks and distribution of reagents. Bethesda: National Institute of Health, Department of Health and Humanservices.

Chantepoy (1993). WHO-network for HIV isolation and characterization, 19921993. Pilot Study in Thailand. Bangkok: Mahidol University.

Cheinhsong-Popov, R. (1993). Results on serological analysis. Londen St. Mary's Hospital Medical School.

Downing, R. (1992). Activity Report of Primary Research Laboratory in Uganda. Entebbe: Uganda Virus Research Instïtute.

B

148

Fenyo, E. (1993a). Prelimimary Report. Biological Characterization of HIV isolates. Stockholm: Karolinski Institutet.

Fenyo, E. (1993b). Preliminary results of neutralization assays. Stockholm: Karolinski Institutet.

Hahn, B. (1993). Results of the PCR amplification, cloning, transient expression and nucleotide sequence analysis of HIV-1 envelope genes from the WHO network for HIV isolation and characterization. Birmingham: University of Alabama. Holmes. H. (1993). Isolation data. Potters Bar: National Institute for Biological Standards and Control.

Karita, E. (1993b). Activity Report of the Primary Research Laboratory in Rwanda. Antwerp: Institute of Tropicall Medicine.

Korber, B., Meyers, G. (1993). Working Report. HIV Sequence Database and Analysis. Los Alamos National Laboratory.

López-Galindez, C. (1993a). The results of the Rnase a mismatch method analysis of the WHO samples. Madrid: Instituto de Salud Carlos. HI, 26 juli 1993.

Lopez-Galindez, C. (1993b). The results of the Rnase a mismatch method anaIysis of the WHO samples. Madrid: Instituto de Salud Carlos III, 17 augustus 1993. Korber, B. (1993). WHO requested information. Los Alamos National Laboratory. Maccutchan, F. (1993). Interim Report to the WHO technical Working Group on HIV-1 Isolation and Characterization. Rockville.

Meyers, 6. (1992). Proposal to the WHO Global Programme on Aids. Los Alamos National laboratory.

Meyers, G. (1993a). WHO/GPA Network Nomenclature Proposal. Los Alamos National Laboratory. 
Meyers, G. (1993b). WHO working report. Los Alamos National Laboraton.

Mullins; 1. (1993). Technical report and working paper on the screening assas. sment of the genetic relationships between viral samples. Stanford: Stanford University School of Medicine.

Najera, R. (1992). Proposal for the Genetic Characterization of field isolates by laboratory of molecular virology of the Centro Nacional de Biologia Celular $y$ Retrovirus. Madrid: Instituto de Salud Carlos III.

Nara, P. (1993). WHO Report. Virologic and Immunotypic Analysis of HAIV. Bethesda: National Institutes of Health.

Rübsamen-Waigmann, H. (1993). Summary data on virus culture and preliminary characterization. Frankfurt: George-Speyer-Haus.

Saragosti, S. (1993). Voici les sêquences. Paris: Laboratoire d'Oncologie Cellulair et Moléculair.

Schochetman, 6. (1993). CDC results. Bethesda: Centres for Disease Control.

WHO/GPAJOffice of Research/Vaccine Development Unit (1992). WHO network for HIV isolation and characterization: proposed collaborative study for initital chatr" acterization of HUV isolates from potential WHO-sponsored sites for HIV Vaccine evaluation (1992-1993). Letters of intent, summary proposal and estimated budget. Genève.

WHO/GPA/Vaccine Development Unit (1993). Publication policy of the "WHO-netw. ork for HIV isolation and characterization". Fifth Draft. Gemève.

\section{Artikelen}

Korber, B. (e.a.)(1994). The World Health Organization Global Programme on AlDS. Proposal for Standardization of HIV Sequence Nomenclature. Aids Research and Human Retroviruses, 10(1), p. 1355-1358.

Myers, G. (1994). Tenth Anniversary Perspectives on Aids: HIV: Between Past and Future. Aids Research and human retroviruses, 10(11), p.1317-1325.

WHO (1995). Scientific and public health rational for HIV vaccine efficacy trials. Aids, 9. WHO1-WHO4.

WHO-network for HIV isolation and characterization (1994). HIV typu variation in World Health Organization-sponsored vaccine evaluation sites: genetic screening. sequence analyses and preliminary biological characterization of selected virat strains. Aids Research and Human Retroviruses, 1o(t), p. $1327-1343$.

\section{Brieven}

Bradac, J. (1992a). Letter of intent, april 29. Bethesda: National Institute of Health, Department of Health and Humanservices.

Bradac, J. (1992b). Expansion of virusisolates in support of the WHO HilV isolation and characterization, april 29. Bethesda: national Institute of Health, Department of Heaith and Humanservices.

Fenyo, E. (1992b). Biological Characterization of HIV isolates. Letter of Intent, march 10. Stockholm: Karolinski institutet.

Goudsmit, 1. , De Wolf, F. (1992). Letter of intent, march 17. Amsterdam: Universiteit vari Amsterdam. 
Hahn, B. (1992). Letter of intent, march, 19. Birmingham: University of Alabama. Najera, fi. (1992). Letter of intent, marh, 10. Madrid: Instituto de Salud Carlos III.

Nara. P. (1992). Letter of intent concerning neutralization assays. Bethesda: National institutes of Health.

Rubsamen-Waigmann, H. Dietrich, U, Grez, M. (1992a) Letter of intent. Genetic Screening of HIV isolates, february 12. Frankfurt: George-Speyer-Haus.

Rubsamen-Waigmann, H., Dietrich, U., Grez, M. (1992b) Letter of intent. DNA sequencing of HIV isolates, february 12. Frankfurt: George.Speyer.Haus.

Rúbsamen-Waigmann, H., Dietrich, U., Grez, M. (1992C) Letter of intent. Characterization of the blological properties, february 12. Frankfurt: GeorgeSpever.Haus.

Rubsamen-Waigmann, H. (1992d) Letter of intent. Function as central laboratony for virus isolation, february 12. Frankfurt: George-Speyer.Haus.

Rubsamen-Waigmann, H.(1992 e). Applification for funds, report on previous activity; rebruary 12. Frankfurt: George-Speyer-Haus.

Schochetman, G. (1992). Letter of intent concerning animal model research, may 28. Bethesda: Centres for Disease Control.

Weber, 1. (1992). Letter of intent, 5 March. Londen: 5t. Mary's Hospitall Medical School.

Weiss, R. en McKeating, I. (1992). A critical letter of intent, march 4. Londen: Chester Beatty Laboratories.

\section{Richtlijnen}

WHO (9990). Guidelines for Counseling about HIV infection and disease. Genève: World Health Organization.

Fenvo, E. (1992a). WHO guidelines for standard HIV isolation procedures (third draft), februari 1992. 


\section{Summary}

This study analyzes the approach of the World Health Organization (WHO) by focussing on the development of a registration. The WHO is an international organization that, together with its member states, aims to improve the health of the world's population. The WHO presents itself as a technical and apolitical organization. The technical character of the WHO is apparent, for example, in the organizational structure, the staff composition and the program choice. Many critics argue that the WHO is too technical. According to these critics, the organization focuses too exclusively upon developing medical knowledge and improving technical facilities. They expect the WHO to take a more political stance, to ensure that more politically sensitive issues, such as birth-control, or the health care system's economical interests, can be addressed. Despite increased criticism, the WHO wants to continue its technical approach of healthcare problems. The WHO maintains that due to the use of medical expertise, healthcare problems can be managed more efficiently, because in this way, politicall commo. tion can be avoided.

One of the WHO's main responsibilities is to develop and maintain registries. The WHO manages several registries, the most well-known of which is the International Classification of Diseases. Above all, registration is exemplary of the WHO's technicall and apolitical approach: the WHO gathers data and orders facts, in order to allow the member states to come to the correct decisions concerning policy. The aim of this research project is to gain insight into the WHO's functioning, by analyzing the development of a registry. The central questions in this project are thus:

1 What kind of work is done to set up a registry?

2 What are the effects of this kind of work on the object of registration, the development of policy, and the relationships between the parties involved with the registration?

To answer these questions, the development of the registration of HIV is described. Using the minutes and other working documents of the project group that 
developed the registry, the work necessary simply for registration can be mapped. The project group consists of representatives of laboratories from different countries and with diverse backgrounds. The intention is for the laboratories to map the genetic and antigenic diversity of HIV together. For this purpose, the "WHO nework for the isolation and characterization of HIV" (the WHO nelwork) was setup. This network is divided into three levels:

1 The primary laboratories in Uganda, Rwanda, Thailand, and Brazil, each of which is responsible for compiling sixty blood-samples.

2 A central repository where all blood-samples are kept and processed.

3 The secondary laboratories that each characterize HIV in their own way.

All data is stored in the Los Alamos National Laboratory (LANL) database.

For the theoretical framework in thesis, concepts derived from figurational socio. logy and from Science and Technology Studies are used. Figurational sociology has contributed to the debate on glabalization in an interesting way. The central issue in the debate is the effects of the ever increasing scale upon which people and organizations function. The number of transactions over vast distances has risen sharply in a short period of time. Worldwide, people are becoming increasingly dependent on one another, and international businesses and organizations are increasing in importance. How do these developments effect society? Using concepts from the debate on globalization, the standard conception about international organizations like the WHO can be abandoned. These arganizations can subsequently be investigated, from a different perspective, as locations where transnational networks are built. Typical of transnational networks are the direct relationships between international organizations and individual citizens (between the international and the local), or between organizations and citizens from different countries (between different local sites). Such tramsnational relationships within international organizations have hardly been researched, despite their obvious importance.

In regards to the functioning of the WHO, scientific knowledge is of central impor tance. However, research on globalization is primarily concerned with the development of worldwide cultural and economical networks. Relatively little attention has been paid to scientific networks, which also span the earth. For this reason, Science and Technology Studies (STS), whose focus is on the daily practice of scientific research, provides a portion of the theoretical foundation in this paper. The main question is what scientists do when they conduct research. From this focus, a new perspective on the age.old philosophical problem of how to differentiate science from other practices and knowledge has developed. According to Bruno Latour, an anthropologist of science, scientists strengthen their claims by linking them to other scientific findings, to theories, to applications, and to societal issues. A scientific claim can thus become part of a wide network of alliances, which explains the solidity of scientific statements. Concepts from Latour's "Actor Network Theory" provide tools to describe the development of a network. Moreover, they allow one to trace possible alterations in the 
object of registration, in the relationships between the associated laboratories, and in the WHO's policy. What has been studied in this project using these theoretical tools?

The WHO network was set up amidst a controversy about the effectiveness of HIV vaccination. At present, large-scale vaccination programs to attack the worldwide spread of AIDS, are the only option open to the WHO. When the WHO took the initiative to set up the registration of HIV in 1989, several HIV vaccines had already been developed. The effectiveness of these vaccines, however, was questioned. Given the special characteristics of HW, doubts were raised whether an effective vaccine could be developed at all. This question was complicated by the fact that it was unclear how to measure the effectiveness of HIV vaccines. In order to develop vaccines, the WHO wanted to collect data about both the genetic and the antigenic diversity of HIV. Mast existing HIV registration programs - that derive from molecular biology - only collect information about genetical diversity. However, the WHO wanted to collect data about antigenic diversity because this information in particular was necessary in the development of vaccines.

In chapter two, the question is whether and how the approach of the WHO, for handling international health problems, may change the controversy. In this chapter, the emergence of the WHO network is described, with an emphasis on the organizational work typical of the WHO - meetings, accounting, facilitating, and the like. The description of these efforts shows how perspectives on the diversity of HIV shift within the WHO network. Instead of positioning one another by opposing differences in method, theory, and views, as is common in science, in the WHO network, such differences could exist side by side.

How exactly does organizational work have an impact on the content of the debate? This chapter shows how the different laboratory approaches to investigate the diversity of HIV are discussed separately during meetings. A report is written of every meeting, outlining the registration procedure. By writing and rewriting these reports, the laboratories develop a common registration procedure without the interference of differences of opinion. The ways in which the experiments are discussed during meetings, and are reported upon afterwards. molds the characterization of HIV in the WHO network. In the network, experiments are performed alongside one another, just like they are discussed and described in meetings and minutes. Also, the material infrastructure set up for the WHO network becomes an important link between the laboratorles. The infrastructure is necessary for two reasons. First, to send the blood that has been gathered by the primary laboratories to all of the other laboratories, to be characterized in the different available ways. Secondly, the WHO has to find a solution for the problem that the laboratories all use different demands to select the material they will use to characterize HIV. Instead of developing a product that suits the minimum demands of all the laboratories, the depot constructs several different products (bloodcells, plasma, virus cultures). In this way, the labo. ratories need not analyze the same material while still being able to tharacteri- 
ze the same viruses. In this (practical) way, the organization of the WHO network thus molds the relationship between genetical and antigenic diversity. Therefore, chapter two shows that while the WHO is renowned for the way in which it is able to obtain consensus, a different analysis of the WHO's orgamizational effort does not comply with this image. The way in which the technical working group develops a proposall for an HIV registration network shows that the group can be effective without reaching a consensus about the relationship between genetical and antigenic diversity, or about the continuation of vaccination studies.

Between 1992 and 1993, a pilot study was conducted, wherein a limited amount of blood-samples was gathered, although all steps necessary for registration were also taken. Chapter three describes, in detail, this process of registration from the wery beginning until the absolute end (from collecting the blood-samples right through to the feeding of data into the database). In setting up the process of registration, the working group built on existing research-structures, classifications, and facilities. The duration of infection, which is related to the chance that the virus will be successfully isolated later in the registration process, can, for example; only be determined for those who took part in prior HIV incidence studies. The classification in genotypes made by molecular biolagists serves as an important foundation for cooperation of laboratories in the genetics subgroup, as it later is for the whole working group. A molecular database, the LANL'S HIV sequence database is used to store the information from the WHO network.

To the $\mathrm{WHO}$, the data from the incidence studies, as well as, for example, the infrastructure necessary to register genetical datca, merely facilitate the development of the registration. However, the network of classifications, facilities, and facts upon which the HIV registration leans, turns out to shape the development of the registration itself. In the beginning, its development is affected by the disciptine of epidemiology. The role of epidemiology is apparent, for example, in the way in which criteria are formulated to select volunteers to participate in the project, the group that is eventually asked to participate, and the kind of data that is gathered from them. Later on, the epidemiological emphasis is diminis hed to the point that the epidemiological information gained from the volum teers is saved, for practical reasons, in a database separate from those data that are used to characterize HIV.

Increasingly, the role of molecular biology gains importance in the development of the registration. The differentiation in genotypes, based on the registration of HIV sequences, can not be stabilized at first. The results from the methods used to determine the HIV genotype diverge. The way in which these methods are evaluated, increases the identification between genotypes. Eventually, the classification in genotypes actually becomes the model for the identification in sero. types. The decision to use the LANL database as the location to store the information. strengthens molecula: biology's position in the WHO network. In this database, the information on genetic diversity is primary. This primary position does not only refer to the order in which information is sorted, but also relates 
to differences in standardization of information, which has consequences for the possibility of its exchange and analysis. Chapter three shows that the aim of registration was to map the genetic and antigenc diversity of the HIV virus. However, along the way, antigenic diversity was molded by and became subordimate to genetic diversity.

Chapter four focuses on transnational relationships. The WHO network's subsidiary aim is to improve collaboration between westem and developing countries. First, the WHO aims to stimulate HIV research in developing countries. Second, it aims to use the gathered information about HIV in developing coun. tries immediately in the planning of vaccination studies in those countries. More equal relationships are a necessary prerequisite for the intended collaboration. Therefore, the WHO intends to strengthen the position of the primary laborato. ries in comparison to the secondary ones, as well as the position of volunteers in relation to the WHO network. To do this, the WHO has taken a variety of initiatives. The working group has set up a training program for researchers of primary laboratories. Also, the secondary laboratories have developed simple techniques that can be used by the primary labs to characterize HIV. The practice, however, as will be shown in chapter four, is different.

During the process of registration, choices are made that seem to have little to do with the relationships between primary and secondary labs, nor with the relationships between volunteers and the WHO network. Take for example, the decision to isolate HV centrally, or the agreements made about publication of the research results. Together, such decisions, made on separate occasions and moments, have the effect of decreasing the number of tasks assigned to primary laboratories in relation to what was intended. The further effect is that their work is not considered scientific, and that they are not included as authors of scientific publications, resulting from the study. in a similar way, vollunteers are linked to the WHO research for a longer period of time than planned, without having giver their consent. This happens because primary laboratories select volunteers who have participated in WHO research before. These volunteers can easily be traced from the information gathered during prior research projects. Thus, the way in which the transnational relations develop in the WHO network, are the result of separate choices that seem unconnected to a preconcelved plan or a general thrust. Still, it is no coincidence that the total effect of these unrelated decisions shows a specific inclination. After all, a specific infrastructure has alre. ady been developed for recruiting volunteers, and for gathering and isolating blood-samples. For this reasorn, some choices have become more obvious than others. If the WHO wants to divert from the more evident course of action, the effort will be greater. In conclusion, without extra effort, the already existing links of the network will become stronger, while the others will become weaker. The existing relationships are thus reinforced rather than changed.

In the concluding chapter, the description of the work done by the WHO in this thesis is contrasted to the WHO's self-image. The WHO presents itself as being 
concerned with neutrality in all areas. It sees itself as refraining from taking any political stance and aims only to facilitate the development of knowledge and policy measures. As long as the WHO insists on this image of itself as an apolitical, as a merely technical organization, it will remain blind to the ways in which it effects the content of the knowledge it helps to produce, the direction of the policies it facititates, and the relationships between the different member states, disciplines, researchers, and volunteers it tries to improve. This thesis, therefore shows that the WHO has an active and specific role in developing scientific knowledge and in the construction of transnational networks. 


\section{Curriculum vitae}

Antoinette de Bont is geboren op 18 november 1968 te Grootebroek. Vanaf 1981 tot 1987 doorliep zil het WW op het Bonaventure College te Leiden. Aansluitend studeerde zij tussen 1987 en 1992 Gezondheidswetenschappen aan de Universiteit van Mastricht. Zij is afgestudeerd in de richtingen Theorie van de Gezondheidswetenschappen en Beleid en Beheer van de Gezondheidszorg. Na haar afstuderen werd zij in 1992 AlO bij de vakgroep Gezandheidsethiek en Wijsbegeerte van deze universiteit. Na die periode heeft zij tussen 1997 en 2000 als onderzoeker gewerkt bij het College van Toezicht Sociale Verzekeringen. Momenteel is zij werkzaam als universitair docent bij het Instituut Beleid en Management van de Gezondheidszorg van de Erasmus Universiteit te Rotterdam. 
calofon

wommgewing:

Yusuf Kho Amsterdam

Engelse samenvatting:

Ruth Benschop 